
FLASHLIGHTS ON NATURE 



\section{FLASHLIGHTS ON NATURE}

RY

GRANT ALLEN

ATTHOR 'Ó

"The Story of the Plernts"

" Earolution of the ldide of Gerd"

itc.

MLLSTRATED BY

FREDERICK ENOCK

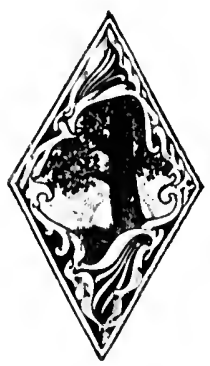

TORONTO

IVILLIAM BRIGGS

29-33 RICHMOND STREET. WEST 1809 
COPYKIGHT, IROS

BY MOUBLEDAY ANI) MCCI.URE CO. 


\section{CONTENTS AND ILLUSTRATIONS}

TIE COWS THAT ANTS MILK . . . . . PACIE

A BRANCH OF THE FAMHLY TRLE . . . . . . 3

WORN-OUT MOTHER . . . . . . . . 5

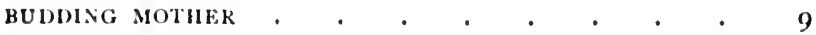

WINGED FEMALE: . . . . . . . . 11

UNNATURAL LODGER . . . . . . . . 12

A TRAGIC ENGMY . . . . . . . . 14

AN ANT MHLKINi; A ROSE MHIS . . . . . I6

A comic linkMY . . . . . . . . 21

A PLANT THAT MELTS ICE • • . . . 25

LEAVES OF SOLDANHA.l.A . . . . . . . 33

BUD BEGINNING TO MELT ITS WAY TP. . . . 34

BUD ENCLOSEN IN A GLOBE OF AIR . . . . 35

FI.OWER REACHISG SURFACE OF ICE . . . . 36

FLOWER VISITED BY A BH.F. . . . . . . . 37

A GROUP OF FLOWERS PROTRUIIT; THROFGII ICE . 39

A PAIR OF FLOWERS WIICH HAVE FAILFI) . • • 41

A BEAST OF PREY . . . . . . . . 47

COCOON OF YOLNG SPIDERS . . . . . . . . 49

YOUNG SPIDERIINGS CASITAC FIKST THRLAUS . . 52

BABY SPIDER IN ITS FIRST SNARE . . . . . 53

ROSALINI'S SPINNERETS . . . . . . . 56

FOOT, CIAWS, ANI FACE OF SPIDEK . . . . 57

ROSALIND ON HER WAY TO MI.OW-FLY . . . . 62

ROSALINI) TRUNDLING BLOW-FLY . . . . . $6_{3}$

A SPIDER CHANGING its ciothes . . . . . 65

ROSALIND AND HER SUITORS. . . . . . 67 
A WOODLANI TRAGilly

PAGR

THE RUTCHER-BIRL 。

71

THE BUTCHAR-BIKH'S WHV:

74

PAR'J OF HIS I.ARDI:K

75

IIS WIFE IMHALING A MARIISI-MUUSL.

76

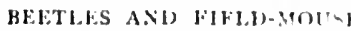

79

"I WANT THAT HLY"

84

THE WIFE ON HER NEST

86

87

MARRIAGE AMONG; THE ('UNFRS

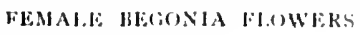

94

THE SEED-HM: .

PLOWERS IN BUH

MALE H.MWLR, FRUNI VIEW

MALE FLOWE, BACK VH:W

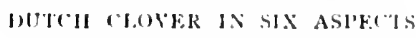

STRAWBLRRY CIOYLR IN FIVE ASPLCTS .

96

98

99

100

IOI

$105-113$

$115-119$

THOSE HORKII) FARWILS . . . . . . $12 \mathrm{I}$

HOR'TRAT OF A CENTIEMAN. . . . . . . 124

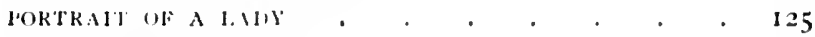

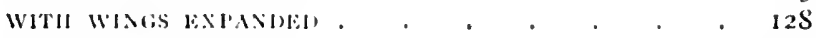

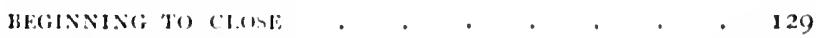

SEVEN FIRTHER STARBS. . . . . . 130136

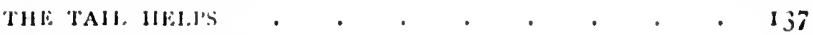

THF USE OF THIE PINCYRS • • • . . . I38

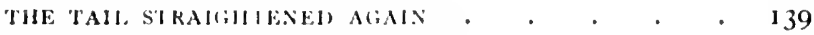

THE WING HENATH THE WNG-CASE. . . . I40

THE WING- ASE RAISBH . . . . . . . 141

SITTING ON IIER BATLS . . . . . . . 142

HE1. BROOH OF CHICKS . . . . . . . 143

CAMPODEA. , . . . . . . . . 144

THE EARWIG'S MOUTH . . . . . . . I45

THE FIRST PAPEK-MAKLR . . . . . . 148

FAMILY PORTRAITS . . . . . . . . 150

THE CITY, TYO HAYS U1, . . . . . . 156

THE CITY, HIVE DAYS OII . . . . . . 157 
THE CITS, FIJTEE. DASS OI,

NEST OF TREF WASI, TWO ASTECT

158

WASI'S IIFAD IN JIVF ASIRT'S

114,105

gUEE. WASP WIII FULINEI WISGS

$10 S 172$

PAKT OF TWO WING

173

THE POISON-BAC;

MAR'TS MARINIILI)

TIE WASI"S BRUSII ANI) (OMIs

174

175

176

THCKS IN TIE SERMLNTS

176

177

\section{ABIIING CITILS}

179

A WOOD ANTS' Nist, FITERIUR

1 So

A WOO1) ANTS' NHSt, INIERIOR

ISI

"I.ET'S GO -IAYr-HUNIIN,"

A SIAVE-IIUNT.

PMING OFF UID SCURI.S .

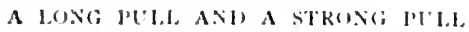
TIIE GARINEN ANT

156

ISo

- 190

191

$\circ .0 .0194$

HEAT) OF (BARIFX ANT . . . . . . 196, 197

TIE ANT'S RRUSH ANU COMB.

199

\section{A FROZFN WORID . . . . . . . . 204}

HIE (IRLAT IONJ)SNAH. IN SLMMIR . • . . 2I2

TIIE ("DFA'T PUNI)-SNAII, IN WINILK . . . . 213

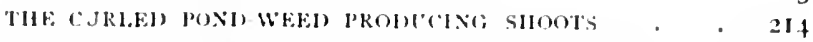

'HE SHO ITS BEIORE, IURIN(;, ANJ AFIEK FROST 215217

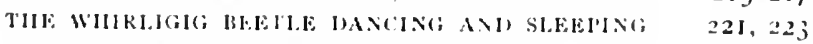

THE FROGBH IN SLMMER ANW HINTKK . . 225,227

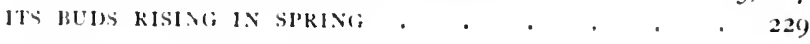

BRITISH BLOODSUCKERS' . . . • . . 232

THE MOSQUTTO'S EGG-RAF', IN TWO ASIECTS. . 236, 237

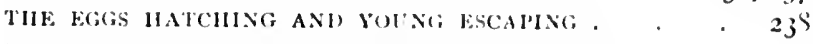

THE MUSQUTO LARYA STANHIN ON HIS HLAL . . 239

THE IARVA'S BREATIING-TUBE , . . . . 2.4

THE CHRYSAIIS BREATIIING . . . . . . 242

THE MOSQUITO EMLRGES . . . . . . 244

ANI MAKES A BOAT OF IIER (II) SKIN. . . . 246 
HFAHS UF MOSQULTOLS . . . . . . . 247

THE GAHIL . . . . . . . . 252

HIS R.ANCHS . . . . . . . . 254

ANU THIIR CUTHNG HITHS . . . . . . 256

A VERV INTELLIGENT ILANT . . . . . $25^{8}$

TIE, BAHY GORSF PLANT. . . . . . . 262

AT (INE WFEK OLI) . . . . . . . . . 263

OUTIKOWING ITS INFANT STAGI . . . . . 260

THE. YOUNG SIIRUB BHoINS IO XRM HTSEIF . . , 267

IIH: GiNISTA . . . . . . . 268

THE BR(NON . . . . . . . . . . 269

HROTHCTSN TILE lULS . . . . . . . 270

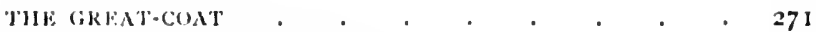

THE FINER, HALF OPLNH. . . . . . . 276

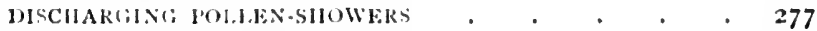

THL POI, WITI BEANS. . . . . . . 280

THF, POL, AFTKR HISHARIING BHANS. . . . 281

A FOREIGN INVASION OF FNGIAND . . . $\mathbf{2 8}_{4}$

A.N INVAIMI BARLEY PIANT . . . . . . 288

THE SURCF TH THE MISCHILF . . . . 289

TIIE GRUL AT WORK . . . . . . . 290

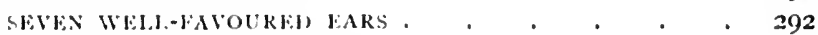

SEVEN I.EAN LARS . . . . . . . . 293

TIE GRUH TIRNING ROUNI) . . . . . . 295

THE CHMHIXG PUPA. . . . . . . . 299

THE JUAS CUMES OUT . . . . . . . . . 300

A.NI THE FIY CONES OLT WF IT . . . . . 3OI

ANTENNE JKFE! . . . . . . . . 302

WINGS FRIE! . . . . . . . . . 303

NOW JOK THE LEGS ! . . . . . . . . 304

TIF IAST PU1.1. • . . . . . . . . . 305

HANGING HERSELF UP TO DRY . . . . . . 305

WLY ENEMY LAYING IIER HGGS . . . . . 311 


\section{FLASHLIGHTS ON NATURE}

\section{I \\ THE COWS THAT ANTS MILK}

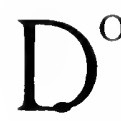

ON'T let my title startle you; it was Linnacus himself who first invented it. Everybody knows the common little "green-flies" or "plant-lice" that cluster thick on the shoots of roses; and most people lnow that these troublesome small insects (from the human point of view) are the true source of that shining sweet juice, rather slimy and clammy, that covers so many leaves in warm summer weather, and is conimonly called honey-dew. A good many people have heard, too, that ants use the tiny green creatures in place of cows, coaxing them with their feelers so as to make them yield up the sweet and nutritious juice which is the ants' substitute for butter at breakfast. But comparatively few are aware how strange and eventful is the brief lifehistory of these insignificant little beasts which we destroy by the thousand in our flower-gardens or conservatories with a sprinkle of tobacco-water. 
To the world at large, the aphides, as we call them, are mere nameless nuisances - pests that infest onr choicest plants; to the eye of the naturalist, they are a marvellous and deeply interesting group of animals, with one of the oddest pedigrees, one of the queerest biographies, known to science.

I propose, therefore, in this paper briefly to recount their story from the cradle to the grave; or, mather, to be literally accurate, from the time when they first emerge from the exg to the moment when they are eaten alive (with some hunclreds of their kind) by one or other of their watehful enemies. In this task I shall be aided not a little by the clever and vivid dramatic sketches of the Aphicles at Home, which have been prepared for me hy my ahle and watchful collaborator, Mr. Frederick Enock, an enthusiastic and observant naturalist, who thinks nothing of sitting up all night, if so he may eatch a beetle's egg at the moment of hatching; and who will keep his eye to the microscope for twetre hours at a stretch, relieved only by occasional light refreshment in the slatpe of a sindwich, if so he may intercept some rare chrysalis at its moment of bursting, or behold some special grub spin the silken cocoon wi hin whose case it is to develop into the perfect winged insect.

Rose-iphides, or "green-tlies," as most people call them, are, to the casual eye, a mere mass of living "blight"-a confused group of tiny trans- 


\section{THE COWS THAT ANTS MILK}

lacent insects, moored by their beaks or suckingtubes to the shoots of the plant on which they have been born, and which they seldom quit unless forcibly ejected. For they are no Columbuses. The spray of rose-bush figured in sketch No. I shows a small part of one stach numerous househoke in quiet possession of its fantily tree and

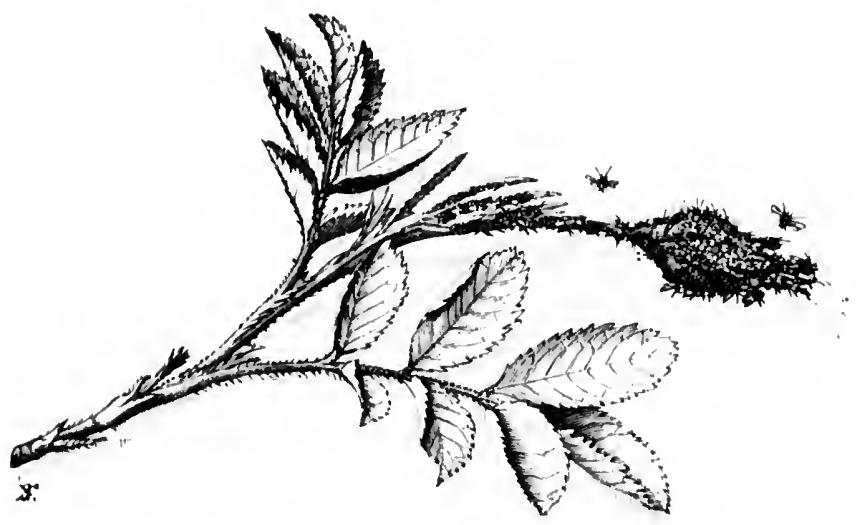

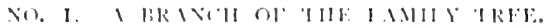

engaged, as is its womt, in sucking for deat life at the juices of its own peculiar food-plant. Fon will observe that they are chustered clonest at the growing-point. Each little beats of this complex family is coloured protectively green, so at to be as inconspicusens as possible to the kecule eyes of its numeroms enemies; and ach sticks to its chosen twig with beak and sucker at long at there is any- 
thing left to drink in it, only moving away on its six sprawling legs when its native spot has been drained dry of all nutriment.

We often talk metaphorically of vegetating: the aphis vegetates. Indeed, aphides are as sluggish in their habits and manners as it is possible for a living and locomotive animal to be : they do not astually fasten for life to one point, like oysters or barnacles; but they are born on a soft shoot of some particular plant; they stick their sucking-tube into it as soon as they emerge ; they anchor themselves on the spot for an indefinite period; and they only move on to a new "claim" when sheer want of food or force majeure compels them. The winged members are an exception: they are founders of new colonies, and are now on their way to some undiscovered Tasmania.

And, incleed, as we shall see, these stick-in-themud creatures have yet, in the lump, a most eventful history-a history fraght with strange loves, with hairbreadth escapes, with remorseless foes, with almost incredible episodes. 'They have enemies enough to satisfy Mr. Rider Haggard or the British schoolboy. If you look at $\mathrm{N}_{0} .2$, yon will see the first stage in the Seren Ages of a rose-aplis family. The cycle of their life begins in autumn, with the annual laying of the winter esgs; these eggs are carefully deposited on the leaf-buds of some rosebush, by a perfect wingless female, at the first approach of the cold weather. I say a perfect wingless female, because, as I shall explain here- 
after, most aphides (and especially all the summer crops or generations that appear with such miraculous rapidity on our loses and fruit-trees) are poor fatherless creatures; waifs and strays, budded out vegetatively like the shoots of a plant.

About this strange retrogressive mode of reproduction, however, I shall have more to tell you in clue time by-and-by ; for the present, we will confine ourselves to the immediate history of the autumn brood, which is regularly produced in the legitimate fashion, as the result of an ordinary insect marriage between perfectly developed males and females. As October approaches, a special generation of such perfect males and females

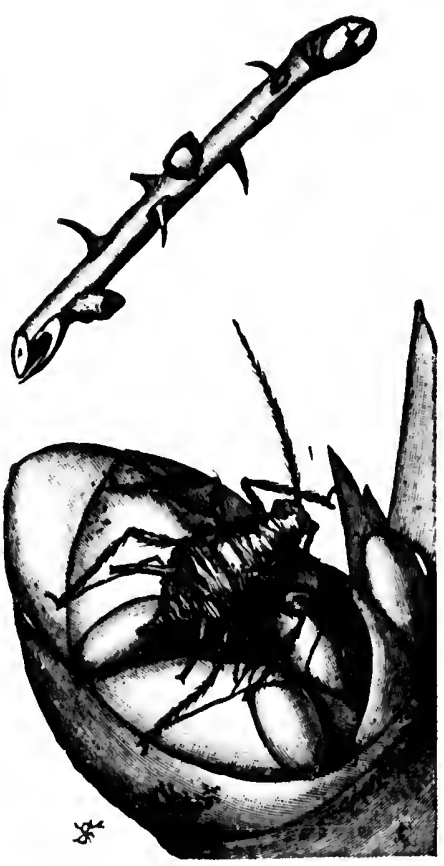
:U. 2.-WWRNOUT NOTHERI.AYING; HER LAST BGG. is produced by the unwedded summer green-flies; and the females of this brood, specially told off for the purpose, lay the winter eggs, which are clestined to carry on the life of the species across the colder months, when 
no fresh shoots for food and drink are to be found in the frozen fields or gardens.

The eggs, so to speak, must be regarded as a kind of deferred brood, to bridge over the chilly time when living aphides cannot obtain a livelihood in the open. In No. 2 we see, above, a rose-twig with its leaf-buds, which are undeveloped leaves, inclosed in warm coverings, and similarly intended to bridge over the winter on behalf of the rose-bush. On this twig, then, we have the winter eggs of the aphis, mere dots represented in their natural size; they are providently laid on the bud, which in early spring will grow out into a shoot, and thus supply food at once for the young green-flies as they hatch and develop. So beautifully does Nature in her wisclom take care that blight in due season shall never be wanting to our Marshal Niels and our Gloires de Dijon!

In the same sketch, too, we have, below, a pathetic illustration, sleatly masnified, of the poor old worn-out mother, a martyr maternity, laying her last egg in the crannies on the bud she has chosen. I say "a martyr to maternity" in solemn earnest. Yon will observe that she is a shrivelled and hagsard specimen of over-burdened motherhood. The daties of her statio. have clearly been too much for her. The reason is that she literally uses loceself up in the production of offspring; which is not surprising, if you consider the relative size of essy and ess-layer. When this model mother began to lay, I can assure 


\section{The Cows that Ants Milk}

you she was fat and well-favoured, as attractive a young green-fly as you would be likely to come across in a day's march on the surface of a rosetwig. But once she sets to work, she lays big eggs with a will (big, that is to say, compared with her own size), till she has used up all her soft internal material; and when she has finished, she dies-or, rather, she ceases to be; for there is no:hing left of her but a dried and shrivelled skin.

During the winter, indeed - in cold climates at least-the race of aphides dies out altogether for the time heing, or only protracts an artificial existence in the heated air of green-houses and drawingrooms. The species is represented at such dormant periods by the fertilised eggs alone, which lie snug among the folds or scales of the buds till March or April comes back again to wake them. Then, with the first genia. weather, the eggs hatch out, and a joyous new brood of aphides emerges. And here comes in one of the greatest wonders; for these sump groods do not consist, like their parents in autumn, of males and females, but of imperfect mothers-all mothers alike, all brotherless sisters, and all budding out young as fast as they can go, without the trouble and expense of ', father. They put forth their progeny as a tree puts forth leaves, by mere division. The new broods thus produced are budded out tail first, as shown in No. 3, so that all the nembers of the family stand with their heads in the same direction, the mother moving on as her offspring increases; 
and since each new aphis instantly begins to fix its proboscis into the soft leaf-tissue, and in turn to bud out other broods of its own, you need not wonder that your favourite roses are so quickly covered with a close layer of blight in genial weather.

To say the truth, the rate of increase in aphides is so incredibly rapid, that one dare hardly mention it without seeming to exaggerate. A single industrious little green-fly, which devotes itself with a quiet mind to eating and 1 eproduction, may easily within its own lifetime becone the ancestor of some billions of great-grandchildien. It is not difficult to see why this should be so. The original parent buds out little ones from its own substance at a prodigious rate; and each of these juniors, reaching maturity at a bound, begins at once to bud out others in turn, so that as long as food and fine weather remain the population increases in an almost unthinkable ratio. Of course, it is the extreme abundance of food and the ease of living that result in this extraordinary rate of fertility; the race has no Malthus to keep it in check-each aphis need only plunge its beak into the rose-shoots or leaves and suck; it can get enough food without the slightest trouble to maintain itself and a numerous progeny. It does not move about recklessly, or use up material in any excessive intellectual effort; all it eats goes at once to the production of more and more aphides in rapid succession.

Many things, however, conspire to show that 
aphides did not always lead so slothful a life : they are creatures with a past, the unworthy descendants of higher insects, which have desenerated to this level through the excessive abundance of their food, and through their adoption of what is practically a parasitic habit. When life is too easy, men and insects invariably degenerate: struggle is good for us. One of these little indications of a higher past Mr. Enock has given us in the upper part of sketch No. 3. For some members of the brood gothrough regular stages of grub and chrysalis, like any other flies ; or, if you wish to be accurately scientific, pass through the usual forms of larva and pupa, before they reach the full adult con-

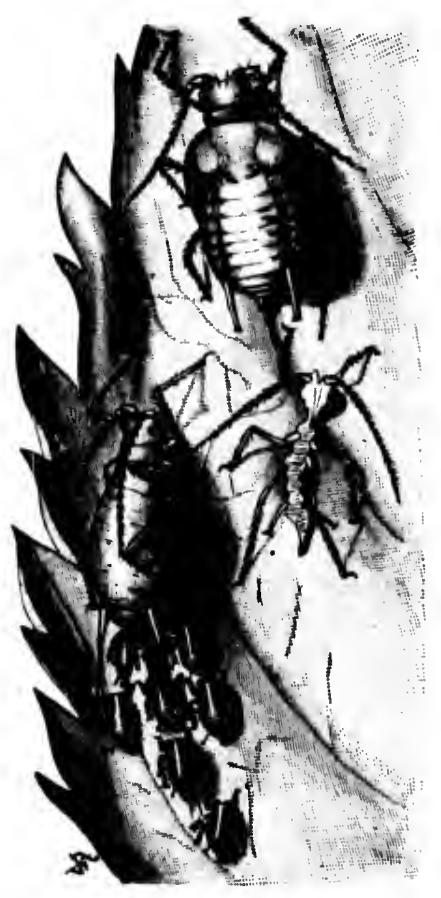

NO. 3. -BUDHING MOTHERPRODUCING A FATHERLESS BROOD

dition. This, of course, shows them to be the deseendants of higher insects which underwent the common metamorphosis of their kind. But most of the budded-out, fatherless broods in summer are 
produced ready-made, without the necessity for passing through larial or infantile stages. Or rather, they never grow up: they merely moult; and they produce more young while they are still larva. They are born fully formed, and proceed forthwith to moor themselves, to feed, and to bud out fresl generations, without sensible interval. In No. 3 we have varions stages in the development of the spring brood. Above we see the pupa, or chrysalis, produced from a grub (not very grub-like in shape), which has sprung from an egs; and on the right, below, we see the shrivelled larval skin from which it has just freed itself. This particular aphis was thus born as a six-legged iarva from an autumn egg; it passes through the intermediate form of a pupa, or chrysalis; and it will finally develop into a winged "viviparous" female, such as you see in No. + helow, putting out its young alive at fast as ever its wee body can bud them. You may observe, however, that in the case of aphides there is no great difference of form between the three successive stages. Larva, pupa, and fly are almost identical.

In No. 4 , again, we have a portrait from life of such a ainged female, the mother of a numerous fatherless progeny; for both winged and wingless forms are produced through the summer. She is round and well-fed, as becomes a matroa. Observe in particular the curious pair of tubes on the last few rings of leer back; these are the organs for secreting nectar or honey-dew, a point about which 
I shall have a good deal more to say presently. A winged female like this may fly away to another rose-bush to become the foundress of a distant colony. The same illustration also shows, in a greatly enlarged form, her beak or sucking apparatus, which consists of four sharp lance-like siphons, enclosed in a protective sheath or proboscis, and admirably adapted both for piercing the rose-twig and for draining the juices of your choicest crimson ramblers. The aphis sticks in the point as if it were a needle, and then sucks away vigorously at the rose-tree's life-blood. You can watch her so any day with a common small mas-

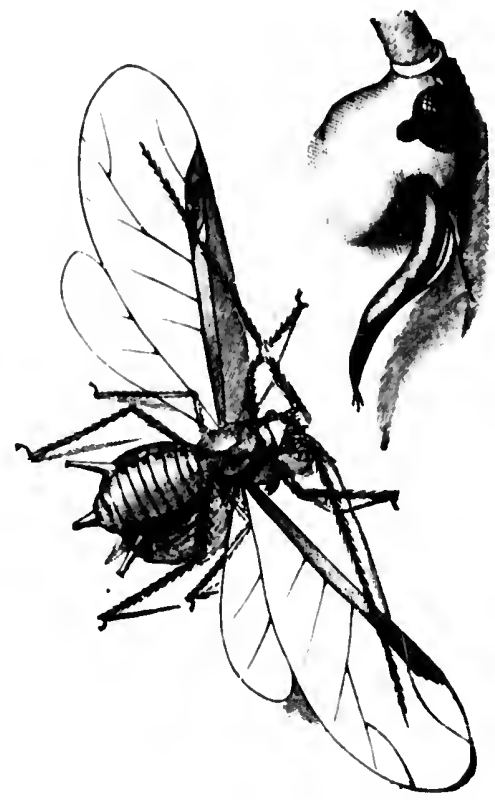

N(), 4.-WIN(\$EI) FEMALE-TIE

HOUNIIRES OF A COLONY. nifier, and see how, like the lady at Mr. Stiggins" tea meeting, she "swells wisibly" in the process. Indeed, aphides are always heatiful objects for the microscope or pocket lens, with their pale, transparent green bodies, their bright black eyes, their 
jointed hairy legs, their delicate feelers, and their marvel'ons honey-aubes; and it will not be my fantt if you still contimue to regard them as nothing more than the "nasty blight" that destroys your roses.

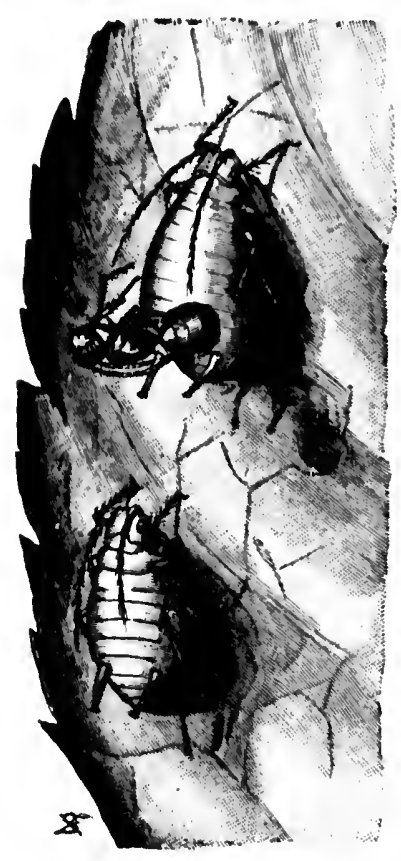

NO. 5.-UNNATURAI, LOLGER EATS HIS IIOSTESS OUT OF IIER SKIN.

Do not for a moment suppose, however, thit you and your gardener, with his spray and his tobacco-water, are the only enimies the rose-aphis possesses. The name of leer foes is legion. Sle is devoured alive, from without and from within, by a ceaseless horde of aggressive belligerents. The most destructive of these enemies are no doubt the lady-hirds, which, both in their larval and their winged forms, live almost entirely on various kinds of green-fly. 'This practical fact in matural history is well known to hopgrowers, for the dreaded "fly" on hops is an aphis ; its abundance or otherwise governs the hop market, and Kentish farmers are keenly aware that a certain particular lady-bird eats the "fly" hy millions, on which account they protect and foster the lady-bird, 
thus leaving the two insects, the parasite and the carnivore, to light it out in their own way between thent.

But No. 5 introduces us to a still more insidious though less dangerous foe: an intermal parasite which latys its egegs inside the body of the budproducing female. There the grub hatches out, and proceeds to eat up its murilling hostess, alive, from awthin. In the sketch, we hate an illustration, below, of an aphis which has thus been compelled to take in a stranger to board and lodge in her stomach; while the top figure shows how the loclger, after eating his hostess out, eats himself out into the open air throush her empty skin. If you look out closely for such hannted sreen-flies, inhabited by a parasite-most often an ichnemmon fiy-you will find them in abundance on the twigs of rose-hushes. They have a peculiar swollen, quiescent look, and a brownisl colour.

No. 6 show's us another such fieree enemy at work. This formiclable insect tiger is the larva of the wasp-tly; he is a savage carnivore, who moors himself by his tail end, stretches out to his full length, and swoops coin upon his unsuspecting prey from above; and heing blessed with a sood appetite, he can set rid of no fewer than I 20 aphides in an hour. As he probably eats all day, with little intermission for rest and digestion, this sives a srand total of ahout i 500 or 1 foo victims at a sitting. However, the remaining aphicles so on budding away as fast as ever to make up the 
deficiency, so the loss to the race is by no means irreparabie. " Il liy a pas d'homme néssarie," Napoleon used to say; and the principle is even more true as applied to the green-flies. If a few millio:ns die, their place is soon filled again.

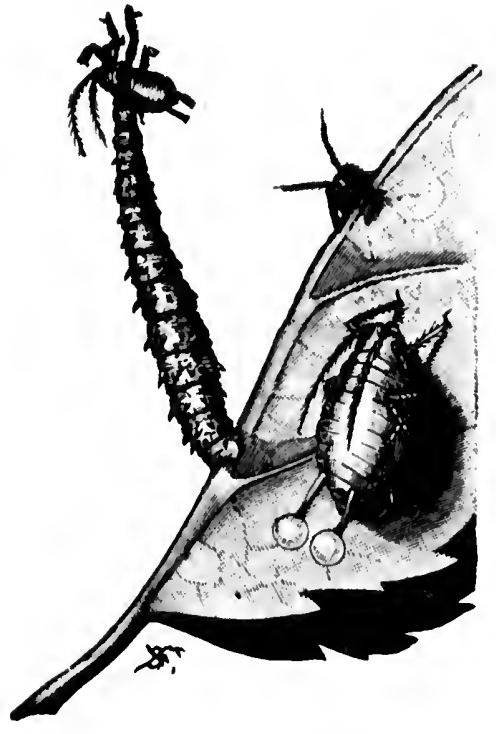

NO. 6.-TRAGIC ENEMY WIIO DEVOURS I2O PER HOUR.

Look once more at No. 6, and you will see that while tlie tiger-like enemy is engaged in hoisting and devouring one unfortunate aphis, its neighbour below, heedless of the tragedy, is quietly engaged in blowing off honey-dew.

This blowing-off of honey-dew leads me on direct to the very heart of my subject; for it is as manufacturers of honeydew and as cows to the ants that aphides base their chrof claim to attention. If they did not produce this Turkish delight of the insect world, nobody would have troubled to study them so closely. Let us go on to see, then, what is the origin and meaning of this curious and almost unique secretion.

If you examine the leaves of a lime-tree or a rose-bush in warm summer weather you will find 
them covered all over with a soft sticky substance, sweet to the taste, and spread in a thin layer upon the surface of the foliage. This sweet stuff is honeydew, and it is manufactured solely hy various kinds of aphides, without whose trade-mark none other is genuine. Why do they make it ? Not, you may be sure, ( of pure unselfish moral desire to benefit the ante ind other beasts that like it. In the anmal world, nothing for nothing is the principle of conduct. The true secret of the origin of honey-dew appears to be this. Aphides live entirely off a light diet of vegetable juices; now, these juices are rich in compounds of hydrogen and carbon, especially sugar (or rather, to be strictly scientific, glucose), but are relatively deficient in nitrogenous materials, which last are needed as producers of movement by all animals, however sluggish. In order, therefore, to procure enough nitrogenous matter for its simple needs, your aphis is obliged to eat its way through a quite superfluous amount of sweets, or of sugarforming substances. It is ahmost as though we ourselves had to swallow daily a harrel of treacle so as to reach at the bottom an ounce of heefsteak. To get rid of this surplus of sugar (or rather, undigested glucose) almost all aphides (for they are a large family, with many separate kinds) have acyuired a pair of peculiar organs, known at honeytubes, on the backs of their bodies. Sometimes, when distended with superfluous food, they simply blow out the honey-dew secreted hy these tubes on to the leaves below them. 
The aphis in No. 6 is represented at the noment when it is thus ridding itself of its excessive sweetness. But honey-dew is sticky, and apt to get in the way ; it maty clog one's legs, or interfere with one's proboscis : so the atphides prefer as a rule to retain it prudently till some friendly animal, with a taste for sweets, steps in to relieve them of the unpleasant tension. The animal which especially performs this kind office for the rose-aphis is the

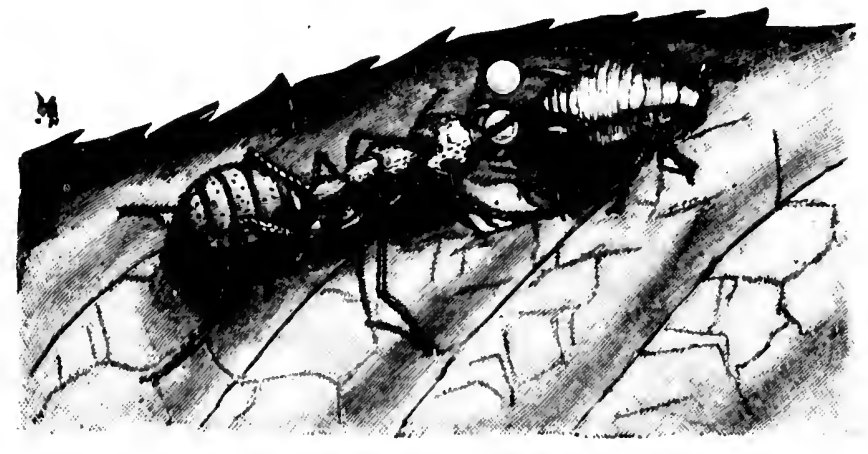

NO. 7.-AN ANT MILING A ROSE-APHIS OF ITS HONEY-IEW.

garden ant; and No. 7 represents such an ant in the very act of tapping and caressing an aplis with its feelers, in order to make her yield up on demand her store of lioney. "The process is ordinarily described as " milking."

You must understand, of course, that neither aphis nor ant is actuated by purely philanthropic considerations; this is a case of mutual accommo- 
dation. The aphis wants to get rid of a troublesome waste product which is apt to clogs it. The ant wants to secure that waste product as a valuable food-stuff. Hence, from all time, an offensive and defensive alliance of the profoundest type has been mutually struck up between ants and aphides. How far this alliance has gone is truly wonderful. The ants not merely "milk" the aphides, but actually collect them tosether in herds and keep them in parks as domestic animals. Naty, more; as Sir John Lubbock has pointed out, different kinds of ants domesticate different breeds of aphides, as each is suited to the other's conditions. 'The common blick sarden ant attends chietly to the aphides which frequent twigs and leares, such as this very rose-aphis-for the black ant is a rover and a good tree-climber; the is much given to exploring expeditions orer the surface of plants in search of honey, and he is not particular whether he happens to gather it from flowers or from insects. The brown ant, on the other hand, goes in rather for such species of aphicles as frepuent the crannies in the hark of trees; while the little yellow ant, an almost suhtermancan ratee, living underground among the gratss roots in meadows, "keeps flocks and herds" (says Lubbock) "of the root-feeding aphides." All these facts you can rerify for yourself with very little trouble.

It is most interesting to watteh a black ant on the prowl after honey-dew. He is evidently led on to the herd by smell, for he momints the stem where 
the aphicles live in a business-like way, and goes straighit to the point, as if he knew what he was after. When he finds an aphis that looks likely, he strokes and caresses her gently with his antennie (as you see in the sketch), coaxing her to yield up the coveted nectar. The aphis, on her side, glad to receive his polite attentions, and accustomed to the signal, exudes a clear drop of her surplus sweet, which the ant licks up with its jaws greedily. But ants do much more than this in the way of aiding and protecting their "cows." They really appropriate them. Often they build, with mud, covered ways or galleries up to their particular herds, and erect earthen cowsheds above them; they also fight in defence of their flocks, ats a \%ulu will fight for his oxen, or an Arab for his camels. Their foresight is almost human: for when the winter eggs are laid, the ants will transport them into their nest, to keep them safe against frost; and when summer comes again, they will carry them out with care, and place them in the sun to hateh on the proper food-plant. Could man himself show greater prudence and forethought than these mites of herdsmen?

"The eggs," says Sir John Lubbock, "are laid early in October on the food-plant of the insect. They are of no direct use to the ants; yut they are not left where they are laid, exposed to the severity of the weather and to innmmerable dingers, but brought into the nests, and tonded with the utmost care through the long winter nonths till 
the following March," when they are brought out again and placed on their special food-plant.

Lubbock even notes that ants have domesticated a far larger ve iety of other animals than we ourselves h:tve. Our list includes at best the horse, the dos, the cat, the cow, the camel, the sheep, the llama, the alpaca, the goat, the hen, the duck, the goose, the bee, the silkworm, and a dozen or so others; while ants have domesticated no fewer than $5^{8}+$ different kinds of crustaceans and insects, including beetles, flies, and mites, some of which have lived for so many generations in the dark galleries of the ant-hills that they have become totally blind, as happens almost always, in the long run, with underground animals.

During the live-long summer the aphides go on, eating and drinkins, budding out new broods with inexhaustible fertility. They settle down calmly on the spot where they were born, they stick to it for life, and they seldom move away from their native twig unless somebody pushes them, for though they have legs, they do not care to use them except on extreme provocation. But when atumm arrives "a strange thing happens." Broods of perfect winged males and wingless females are then produced; and the males of these, like almost all other insects, take a marriage flight, find their predestined mates, and hecome with them the parents of the dormant eggs which outlive the year, and carry on the race to the succeeding summer. While warm weather lasts, few or no 
males are hudded ont; it is only when the cold threatens to destroy the entire colong that little husbands are born, so as to give rise to esgs which may bridge over the gulf between summer and summer. If you keep the insects warm, however, and supply them with abundant food (as in a conservatory), they will go on producing imperfect females and fatherless hroods, withont intermission, for many years tosether. The ess-laying generation is thus sluown to be merely a device for meeting the adverse chances of winter; the hudding process suffices well enough, as long as warmth and food render the possibility of freezing or starvation unimperlant.

On the other hand, the esses and the brood born from them revert to the earlier habit of the race, when it wats still an active, free-flying type, before it had been denomalised hy acepuiring its sedentary, parasitic habits. 'They hatch out into atetive little sixfooted or six-legged larva, which asain, in somecases, give rise to very similar chrysalis forms, and finally develop into the "viviparous" or budding females. Whenever a species earns its livelihood with too little exertion, it invariably degenerates, and often grows small, unintelligent, and vastly prolific; for superior races have relatively small fanilies, while inferior races reproduce by the million. 'The mites which infest cheese and other food-stuffs are an exactly analogous case to that of the aphicles, for they are degenerate spiders, grown small and prolific through the excessive ease of life afforded them by 
alwass settling in a cheese, all ready-made food for them, withont the trouble or exertion of hunting.

Creatures which reproduce at such a rate, however, invariahly paty the penalty for their rapid increase by an equally rapid and enomoms deathrate; were it otherwie, the offisprings of a single pair of codtish (with them million egess) would soon turn the sea into one solid mass of cod; while the

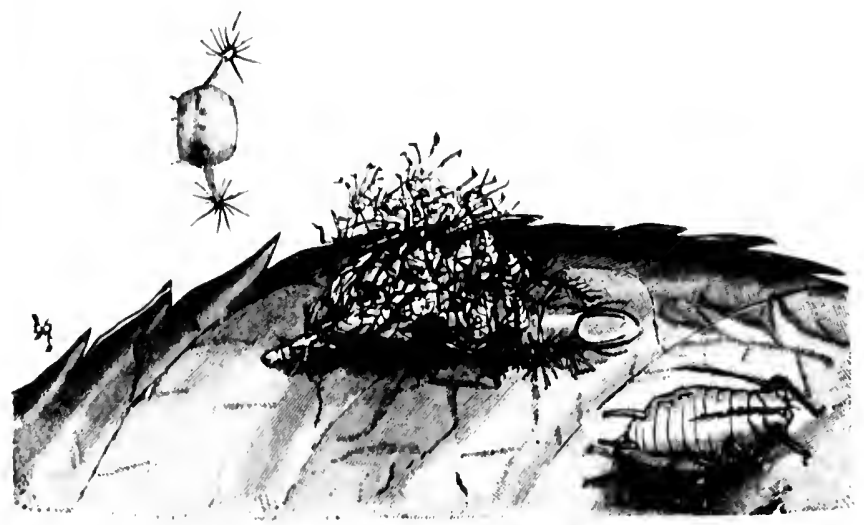

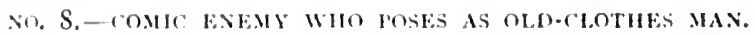

descendants of a single viviparous aphis would cover the earth witli a ten feet thick layer of teeming green-tlies. Howerer, Natme has remedies in store for them. Storms of rain and hail kill mrriads of aphides; sudelen changes of weather wilt them and nip them up ; imnumerable enemies make an honest livelihood ont of them. Another of these nhiquitous foes is graphically represented in No. 8-the 
grub of the lace-wing fly, a sort of insect old-clothes man, which covers its back with the cast-off skins of its discarded victims. This is a clever derice to enable it to escape observation. The larva, which is a fat and juicy morsel, catches aphides wholesale, and sucks their life-blood; when he has clrained them dry, he hoists up their skins on to his back with his jaws, by way of overcoat. Then the hooks or spines on his back (shown above) hold them in place for a time, while the larva bends over and spins a few threads of web across them, to weave them into a neat and compact garment. Thus securely clad, he is hidden from riew : he looks much like a twig covered with aphides, and avoids to some extent the too pressing attentions of his own enemies. Observe in this sketch the characteristic unconcern of the aphis who is destined to be his next victim.

Birds also destroy large numbers of aphides. You can see them picking them off in the beanfields in summer.

It is lucky for us that these insect pests have so abundant a supply of natural enemies; for man, by himself, is almost powerless against them. Strange to say, and paradoxical as it sounds, it is the smallest enemies that we always find most difficult to extirpate. Lions and tigers we can kill off without difficulty ; they can be shot and exterminated. Wolves and hyenas gire us a little more trouble; while against rabbits, our resources are taxed to the utmost. A plague of rats and mice, or of tiny 
field-roles, can hardly be combated with any hope of success; while locusts and Colorado beetles devastate our crops with practical impunity.

When it comes to aphides, we are quite unahle to cope with the infinite numbers of our infinitesimal foes; and if we take the microscopic creatures which catuse cholera, typhoid fever, and other zymotic diseases, we may keep out of their way, it is true, or may isolate the objects in which they breed and store their serms, hut we are practically without means to kill or hurt them. The larger the foe, the more easily is he met; the smaller our enemy, the more difficult is he to extirpate. We killed off the American buffalo (or bison) in a single seneration; a thousand years would probahly fail to kill off the insigniticant little aphides that infest our roses.

In the ease of one member of the family at least the experiment has been tried on a sigantic scale in france, and as yet with comparatively small results. For the dreated phylloxera which attacks the vines is, in fact, an aphis; and though immense rewards have been offered by the french Assembly for any good remedy against phylloxera, the only successful plan as yet proposed has been that of planting healthier and sturdier American vines, which resist the little beast a good deal hetter than the effete and worn-out European species. but many other members of the family wage war with distinguished suceess anatinst the British farmer. The little black "colliers" which attack our bean 
crops are a species of aphis; so are the "blight" of apple-trees, the "fly" on turnips, and the most familiar parasites of the hop, the cabbage, the pear, and the potato. It is well for us, therefore, that the aphides have roused against them so many natural enemies among the birds and insects, or our crops would be destroyed by their persistent efforts. The ichneumon-flies alone kill their millions yearly; and the lady-birds well deserve their popular esteem for the good they do in keeping down the everincreasing numbers of these voracious insects.

Yet, mischievous as they are, the tiny green aphides are well deserving of study, both for their personal beanty and their singular life-history. Everybody can observe them, hecause they are practically everywhere. If you have a garden, they swarm on every hush. If you grow flowers in your window, they live in every pot. If you content yourseif with an occasional hunch of roses or geraniums, you will find them, if you look, sucking away contentedly on the leaves of the rosebuds. Even in London parks or squares you may watch the industrious ants creeping slowly up the stems to milk their wee green cows; you may see with the naked eye, or still better with a pocket lens, the grateful aphis exude a tiny drop of limpid honey from its translucent tubes, and the ant lick it up with unmistakable gusto. Go out into the parks or gardens and examine it for yourself; for every one of the facts I have mentioned in this paper can be verified with ease, if only you bave patience. 


\section{II}

\section{A PLANT THAT MELTS ICE}

TF you have ever visited the Alps in early spring, you will know well by sight the dainty little nodding bells of the alpine soldanella twin flowers on one stalk, like fairy tocsins, which push their heads boldly through the ice of the nive, and form a border of blue blossoms on the edge of the snow-sheet. Most people, to he sure, visit the Alps in August ; and they go too late. Autumn is the time when heather purples our bleak northern moors, but when the central mountain chain of Europe, so glorious in April, has become comparatively green and flowerless. If you wish to see what nature can do in the way of rock-gardens, however, you should go io Switzerland in early spring. It is then that blue gentians spread vast girdles of blossom over the alpine pastures; then that the green slopes on the mountain sides are yellowed by globe-flowers; then that the poet's narcissus stars with its white petals and seents with its sweet perfume the rich meadows on the spurs of the lesser ranges. Higher up, sheets of creeping rock-plants, close clinging to the uneven surface, fall in great cataracts of pink 
and blue over the steep declivities. As the snow melts, upward, the flowers open in zones, one after another, upon the mountain sides, so that you can mark your ascent by the variations in the flora, and the different successive stages of development reached by the most persistent kinds at various levels.

There is one adventurous little plant, however, among these competing kinds, which in its eagerness to make the most of the short alpine summer does not even wait, like its neighbours, for the melting of the snow, but, vastly claring, begins to grow under the surface of the ice-sheet, and melts a way up for itself by internal heat, like a vegetable furnace. It may fairly be called a slow-combustion stove, not figuratively, but literally. It burns itself up in order to melt the ice above it. This wonderful plant is the alpine soldanella, the hardest and one of the prettiest of mountain flowers; it opens its fringed and pensile blue blossoms in the very midst of the snow, often showing its slender head above a thin layer of ice, where it fearlessly displays its two sister bells among the frozen sheet which still surrounds its stem in the most incredible fashion.

So much every tourist to the Alps in May must have noticed for himself, for whenever he reaches the edge of the melting ice-sheet he can see the ice pierced by innumerable twin pairs of these dainty and seemingly delicate blossoms. Comparatively few observers, however, have proceeded to notice that the soldanella, fragile as it 


\section{A Plant that Meits ICE}

is, actually forces itself up through a solid coat of ice, not exactly by hewing its way, but by melting a path for itself in the crystal sheet above it. let such is really the case; it warms the ice as it goes. The buds begin to grow on the frozen soil before the ground is bare, under the hatrdened and compressed snow of the nevéwhich at its edge is always ice-like in texture. They then bore their way up by internal heat (like that of an animal) through the sheet that covers them ; and they often expand their delicate blue or white blossoms, with the scalloped edges, in a cup-shaped hollow above, while a sheet of refrozer: ice, through which they have warmed a tumnel or canal for themselves, still surrounds their stems and hides their roots and their flattened foliase. This is so strange a miracle of nature that it demands some explanation; the method by which the soldanella obtains its results is no less marvellous than the results themselves which it produces.

'The winter leaves of soldanella, which hibernate under the snow just as truly as the squirrel or the dormouse hibernates in its nest, are large, leathery, tough, and evergreen. They are, in fact, just living reservoirs of fuel (like the fat of the dormant bear), which the plant lays by during the heat of summer in order to burn it up again in spring for the use of its flowers. When I use this language, you will think at first I am speaking figuratively. But I an not; I mean it in just as literal a sense as when I say that the coal in 
the tender of a locomotive serves as fuel for the engine, or that the corn in the hin of a stable serves as fuel to heat the horse's body. 'These leaves contain material laid by for burning; and it is by burning that material up at the proper period that the soldanella manases to melt its way out of the wintry ice-sheet, and so to steal a march npon competing species.

The process requires explanation, I admit; let us try to molerstand it. Everybody knows, at a matter of common experience, that animals are warmer in winter than the air which surrounds them; warm-hlooded animals, that is to say, which form the only class most people trouble about. Not everybody knows, however, that the same thing is more or less true of plants as wellthat many plants have the power of evolving heat for themselves in considerable quantities. But this is actually true; indeed, all growing parts of a stem or young leaf-shoot must necessarily be slightly warmer than the air around them. For, when you come to think of it, whence do amimals derive their heat? " From the oxidation of their food," the small hoy of the day, crammed full of knowledge, will tell you, glibly. And what do you mean by oxidation but very slow burning ? You may take a load of hay, and set a match to it, and it will burn at once quickly, hy combining with the oxygen of the air in the open; or you may, if you choose, give it to a pair of horses to eat instead, and then it will hurn up slowly, by 


\section{A Plant that Melts ice}

combining with the oxyesen of the air in thes hollies. lomgs, in fact, ale mere devices for taking in fresh oxygen, which then eombines with the food or fuel in the blood of the anmat.

A century aso, Comnt Rumford pointed out that you might hum your hay as you chose, either in a horse or in a stean-engine; and that in either case you produced alike heat and motion. What we call fuel is just carbou and hydrogen, separated from oxygen ; and what we call burning or eombustion is just the re-muion of the oxysen with the other eiements, aceompanied by a givingoff of heat equivalent in amomnt to that originally reguired in order to separate them.

Now, the foodstufis of most animals are plants or parts of plants, especially seeds or grains, as well as the rich stores of stareh or oil haid by in roots, bulls, and tuhers. These are all of them reservoirs of food or fuel, produced by the plant for its own future growth, and meant hereafter to spront or serminate. All seeds, when they hegin to yuicken, unite with oxygen and evolve heat; and this heat is just the same in nature, whether it happen to be set free within or without an animal hody. If you give an ox corn, he will oxidise it intermally and warm his own body with it ; but if you let it germinate, it will oxidise itself, and so produce a very small hut slow fire, which wams both the corn and the space around it. Similarly, all growing shoots combine with oxysen, and, therefore, rise in temperature. In early spring, when the gromel just teens with sprouting seer?: 
and swelling buds, with growing bulbs or shooting tubers, the temperature of the soil is sensibly raised; and this very heat, evolved by germination, becomes itself in turn a cause of more germination; each seed and root and bulb and sucker helps to warm and start all the others. Spring largely depends upon the warmth thus produced. The earth, cluring this orgy of growth, is warmes by a good deal than the air about it; warmer even than it is in summer weather-indeed, were it not for the number of plants which thus start growing at once, growth would be almost impossible in very cold countries. Like roosting fowls, they warm one another.

You think, however, the amount of heat that can be thus evolved must be very insignificant. By no means. Take an example in point. What do we mean by malting? We collect together a number of seeds or grains of barley, we wet them thoroughly, and allow them to begin germinating. Each grain individually gives out only a small amount of heat, it is true: but when many of them lie together, the total volume of heat produced is very great, and the amount would be even greater if it were not artificially checked at a certain stage: for the maltster does not wish his malt to be "over-heated." Malt, then, is nothing more than sprouting barley; and the heat it begets in the process of malting shows us very clearly how much warmth exists in sprouting seeds, or in the growing portions of young plants, buds, shoots, and tubers. 
At the risk of seeming tedious in this preliminary explanation, I must also add that flower-buds and flower-stems which grow and open very rapidly must similarly use up oxygen in their growth, and therefore distinctly rise in temperature. In a very few large and conspicuous flowers, such as the big white calla lily, this rise in temperature during the flowering period can be measured even with an ordinary thermometer. No hud can open without giving ont heat ; and the amount of heat is sometimes considerable.

And now, I hope, we are in a position to understand how soldanella acts, and why it does so. It is a plant which grows under peculiarly trying conditions. It has to eke out a livelihood in the mountain helt, just helow the snow-line; and it is a low-growing type, which must flower early, or else it would soon be overshadowed by taller rivals. For growth is rapid in the Alps, once the snow has melted. Soldanella has thus to hlosion, and to secure the aid of its insect fertilisers, at the precise noment when they emerge from their cocoons in the first warm days of the short alpine summer. If it waited later it would he overtopped and obscured in a very few days by the dense and rapid growth of waving grasses, and aspiring globe-flowers, and long-stalked, bulbous plants that crowd all around it. So the soldanella seizes its one chance in life at the earliest possible moment, and makes haste to pierce its way through the solid ice-sheet, while lazier rivals passively await its melting. That alone has 
secured its survival and success in the crowded world of the alpine pastures. For you must not forget that while to you and me the Alps are an unpeopled solitude, to the alpine plants they are a veritable London of competing lifetypes.

The canny plant lays its plans deep, too, and begins well beforehand. It has macle preparations. All the previous summer it has been spreading its round leaves to the mountain sun, and laying by material for next year's flowering season. Leaves, you know, are the mouths and stomachs of plants; and the soldanella has a type of leaves admirably adapted to its peculiar purpose: expanded in the sunlight, they eat carbon and hydrogen the live-long summer, and turn the combined oxygen loose upon the air under the influenee of the sun. By the time winter comes, they are thick and leathery, filled with fuel for the spring, and, of comrse, evergreen. They have also long stalks, which enable them during the summer to stretch up to the light ; but in autumn they descend and flatten themselves against the soil, so as not to be crushed by the snows of winter. The first of my illustrations (No. 1) shows a group of these fat leaves, seen from above, and flattened against the ground in expectation of the snow-sheet.

The material laid by in the thickened leaves consists of starches, protoplasm, and other rich foodstuffs. The snow falls, and the leaves, protected by their hard and leathery covering, re- 
main wnhurt by it. The food and fuel they have gathered is stored partly in the foliage and partly in the swollen undergronnd root-stock. All winter through, the plant is thus hidden under a compact blanket of snow, which beeomes gradually hard and ice-like by pressure. But ats soon as the spring sun begins to melt the surface at the lower

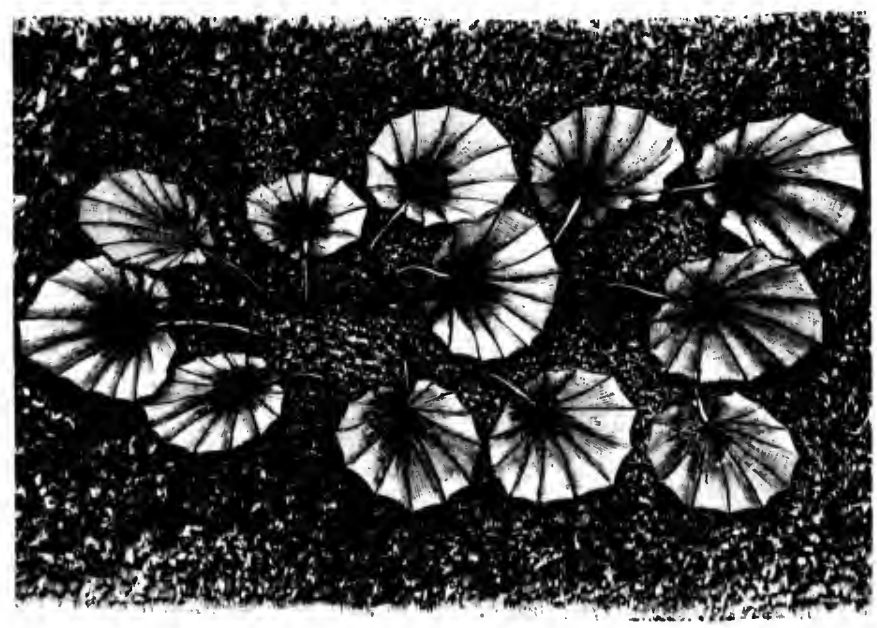

NO. I. - LAVES OF SOIDANELA IN MTUMN, FAT WITI FI: SELE FROM ABOVF.

edge of the sheet, water trickles down through cracks in the ice, and sets the root-stock budding. It produces, in fact, the rery sallue effect as the water which we pour upon malting barley in order to make it germinate. And the same result follows, though here more cletinitely, for the sol- 
danclla hats collected its material deliberately ats fuel, and uses it up on purpose to melt its passage. It absorbs oxygen from the air below the snow, combines it with the fuels in its own substance, evolves heat from their combination, and begins to send up its nodding flower-buds through the icy

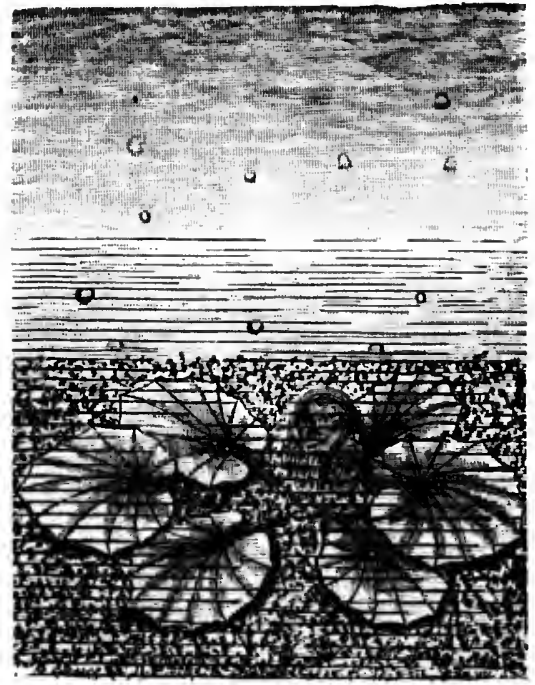

NO, 2. - HLD BEGINNING TO MEIT ITS WAY IP THROUAH ICE IN A DOMESIAPLU HOLLOW: sheet that spreads above it.

The warmth the plant obtains by this curious process of slow internal combustion it first employs to melt a little round hole in the ice for its arched flowerbucls (No. 2). At the beginning, the bollow which is formed above each pair of buds is hemispherical or dome-shaped; the stem pushes its way up through a dome of air enclosed in the iec; and the water it liberates trickles down to the root, thus helping to supply moisture for further growth with its consequent heating. But by-andby the stem lengthens, and the bud is raised to a considerable height by its continuous growth. 
Still, so slight is the total quantity of heat the poor little plant can evolve with all its efforts, that by the time the stem is an inch or two long, the lower part of the tumnel has curiously frozen over again, by the proeess which Tyudall called "regelation," and whoseimportance in glacier action he so fully demonstrated. Inthisstage, then, the melted space is no longer a dome; it assumes the form of a little balloon or round bubble of air, surrounding the flower-bud. At the same time, the ice beneath, laving frozen ayain, almost touches the stem, so that the bud seems to occupy
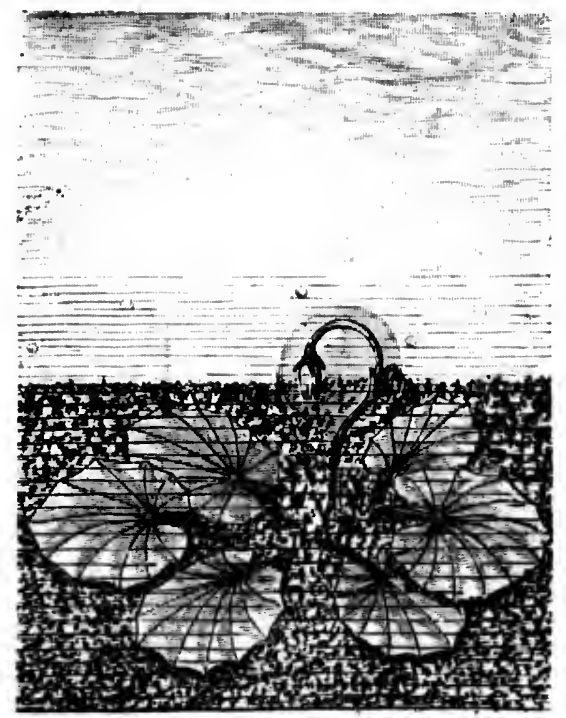

No. 3-BUI, SOMEWUAT LATER, FN(CLOSLI) IN A GLOHE OF AIR WITHIN TII ICL-SHEET.

a small, clear

area of its own in the midst of the sheet, with ice above, below, and all around it (No. 3). You would say that growth under such circumstances, in almost icy-cold air, was impossible-but if you examine the ice-sheet at the edge of the neire, you will find it studded by hundreds of such 


\section{Flashlights on Nature}

hubbles, each enclosings an uninjured soldanella hucl in its centre. The reason is that the heat from the flower keeps the enclosed air just above freezing-point ; and so long as it is not actually frozen soldanclla is indifferent to the cold of its

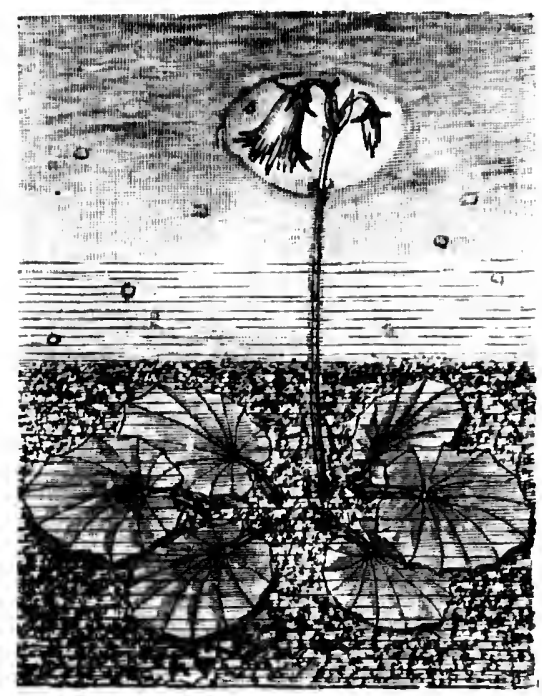

NO. 4-FI.OWLR RliAHIING THE SLR-

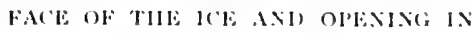
A (CUP-SHAPEI) DERRLSSION. surroundings.

Gradually, in this way, the little buds manage to bore their way to the surface and to the sunshine on the outsicle of the ice-sheet. At last the stalk melts its path out, and a flower appears on the top, in the centre of at small cup-shaped or salucer-shaped depression (No. 4 ). The exquisite blue bells are thus seen blooming in profusion, apparently out of the ice itself, or as if stuck into it. Unless you looked close, and noticed that their stems came from the ground beneath, you might even imagine they were rooted in the crystal mass of the neits. The edge of the snow-field in early spring is often pierced and riddled by hundreds 
of such soldanella borings; others above are in process of formation ; and if you cut a piece open you will see inside how each is prodnced, with its narrow tunnel below, its balloon in the centre, or later, its saucer-shaped depression on the surface. Moreover, if you look at the foliage on the bare ground beneath, you will find that, when the flowers open, the leaves are no longer thick and swollen. All the fuel they contained has by this time been burned up for warmth; all the formative material has been duly employed in making the buds or blossoms, with the stems that raised

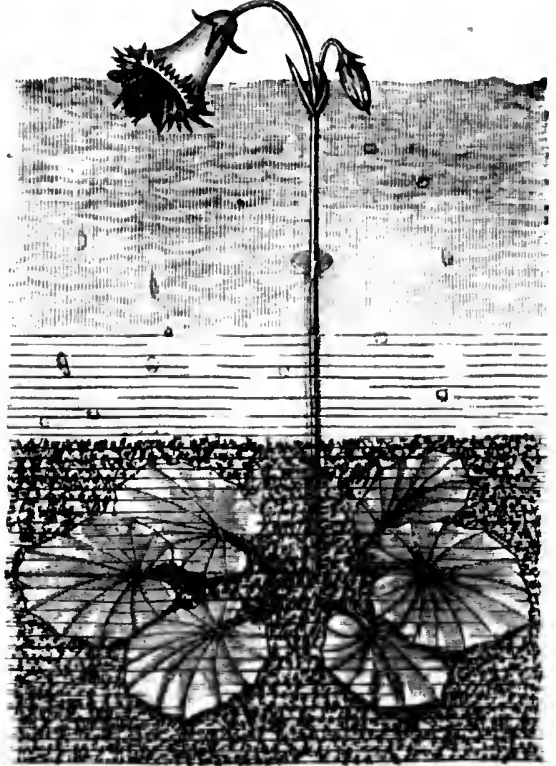

No. 5--PIOWER VISITEN BV A LEE, WHICH FERTIIISES IT, them ; and no-

thing now remains but draned and flaccid skeletons from which every particle of living matter has been withdrawn and utilised. Later on new leaves are produced in turn from the root-stock, after the iee has melted; and these new leaves, raising 
themselves on their long stalks, and catching the sunlight, begin afresh to accumulate material for next year's growth and next year's burning.

But why do the flowers want so much to reach the open air at all? Why should they not blossom contentedly under the enclosing ice-sheet? A glance at No. 6 will serve to explain the reason. Flowers, after all, are mere devices for the fertilisation of the fruit ; it is the seeds and the next generation that the plant itself is mainly thinking about. The blossoms of soldanella are noticeable to us lordly human beings chiefly because they are so pretty; they have a delicate blue or violet corolla, exquisitely vandyked at the edge, and divided (on a closer view) into five more or less conspicuous lobes; so it is their colour and their daintiness that make us so much admire them. But to soldanella itself - which, after all, has to earn its livelihood with difficulty on a stern and rocky soil-this beauty that charms us is a mere matter of advertisement. The plant wants its blossoms to attract the early spring bees and honey-sucking flies, which carry pollen from head to head, and so fertilise its seeds for it. And fertilisation, to the practical-minded plant, is the whole root of the question. It cares no more for the beanty of its flowers in themselves than the British manufacturer of cocoa or soap cares for the gorgeous colours and striking designs he lavishes on his advertisements. "Use Jones's Detergent" is the key-note of the poster. The object of an advertisement is to eatch the eye and secure the money of customers; the object of 


\section{a Plant that Miets ICE 39}

the tlowers, for all their heauty, is just equally to catch the eve and secure the risits of the fertilising insects.

No. 5 shows how all this is managed. At the

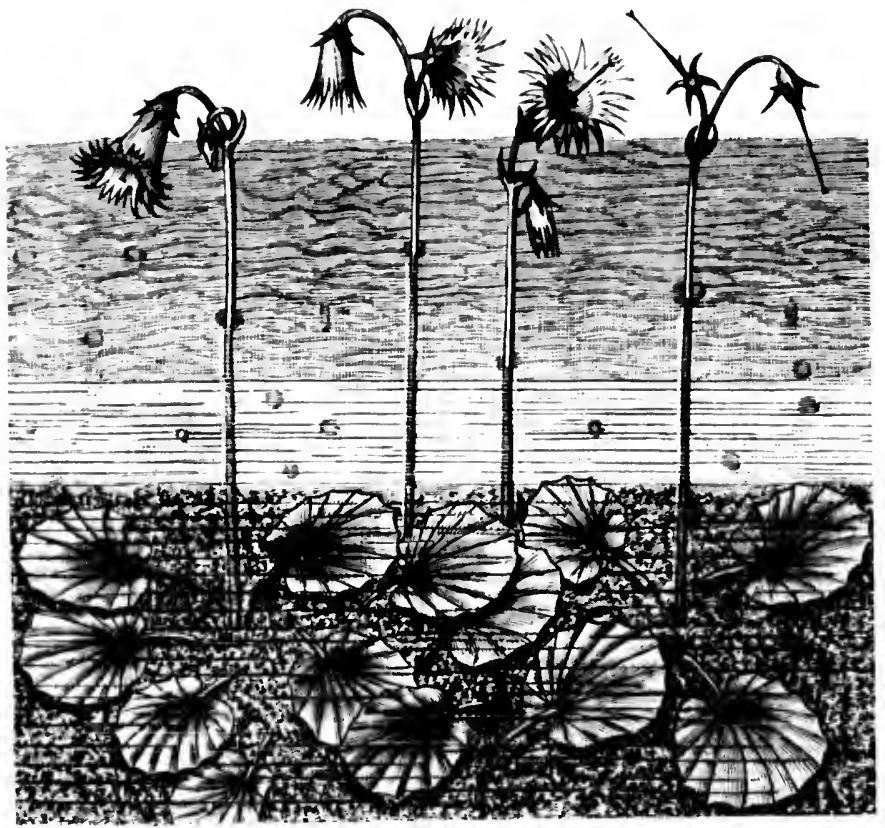

NO. 6. -GROLP OF FIOWERS IN HHFERENT STAGES PROTRUDING THROUGH THE HE-SHEkT.

very same time that the soldanclla raises its timid flowers, the hees and flies a little lower down the monntain sides are just eseaping from their cocoons as full-fledged winged insects. It is for their sakes alone that the pensive hlosions tint themselves in 
blue or violet, for you will find throughout nature that blue is the true hee colour; and flowers that depend most for fertilisation on bees or their allies are almost always decked out in bluc or purple. If you examine a soldanclla closely, too, you will see that all its parts are exactly aclapted to the shape and organs of its most frequent visitor, here represented in the act of rifling its honey. Its bell-shaped hlossoms just fit the insect in size; its stamens shed pollen just where his hairy body is adapted to receive it; its sensitive stigma is so arranged that he rubs the golden grains off on the receptive surface of the next flower le visits. Then the little capsules swell, and the seeds ripen; and the happy soldanella, becoming a fertile mother of future generations, has fulfilled the main purpose of its stormy existence.

Sometimes, however, the ice-sheet above is too thick to pierce; and then the hud, after making manful efforts to melt its way out to the open air, is forced to give up the attempt in despair, and unfold its petals within its icy cavern. In that case, of course, no insect can visit it; and such cloistered blossoms are therefore obliged to have recourse to the inferior expedient of self-fertilisation. I say inferior, because all higher plants strive as far as possible to produce seedlings which shall be the offspring of a distinct father and mother. The last illustration (No. 7) shows two flowers which have lengthened their stalk in vain to the furthest point for which they possess material, but have failed to melt a way out of the solid ice-slieet. 
They are therefore driven to curl round the tips of their stamens and fertilise themselves-a process which almost always produces inferior seeds and very weak seedlings. It is in order to prevent such disastrous results on a large scale, and to aroid the evils of constant "breeding in and in," that soldanella has invented its curious device for pushing its way boldly through its native ice-sheet to the sky and the insects. It goes there, not to look heautiful for you and me, but to secure the aid of
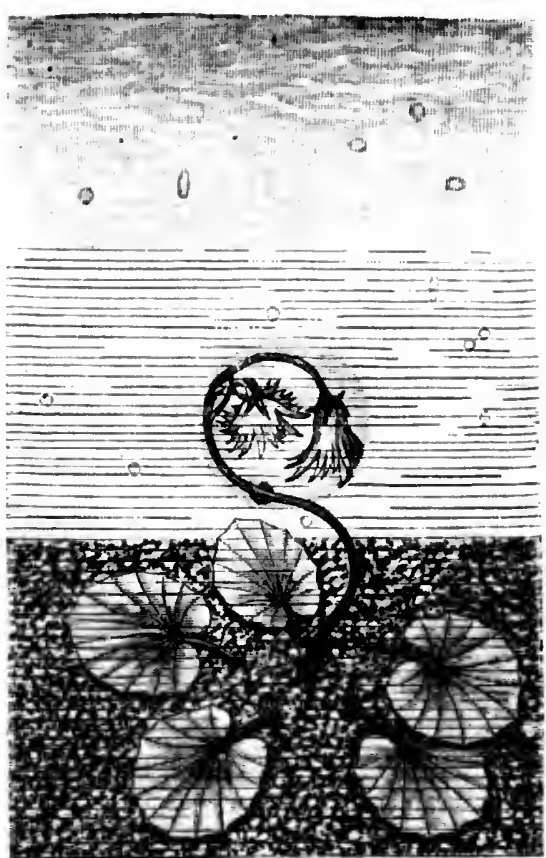
its established pollen-carriers.

You must not

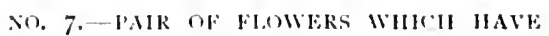
FAIED TU REMCH THE SURFACE, OIEN-

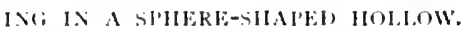
suppose, however, that in doing all this the soldanella is displaying any extratordinary anount of unusual originality. Its speciality consists merely in the somewhat abuormal volume of heat which it generates, A great many 
plants, indeed, proceed much as the soldanclla does in the matter of laying by materials for future growth in the leaves, and using these 11 in the act of flowering. Take, for example, the famous and often somewhat exaggrerated case of the so-called "aloc," or American atgare. It is commonly satid that "the flowering of an aloe" takes place but once in a hundred years. This is a poetical fiction. As a matter of fact, the agave flowers on an average after fifteen or twenty years, and then dies down utterly. Every visitor to Italy or the Riviera knows this huge plant well --a gigantic hous"-leek in form, with its higs spiny leaves and its points sharp as a needle, which defend it as hy a hristling row of bayonets. Now, the agave lays by its material for future growth in the thickened base or lower portion of its leaves; it thus forms a huge rosette, very much swollen ant enlarged at the hottom. For years it goes on with exemplary patience, collecting supplies for its one act of flowering; then at last, feeling its time has come, it suddenly sends up a huge stalk, or trunk, like a vast candelabrum, fifteen, twenty, or even thirty feet high, and supporting at its top a great bunch of big yellow blossoms. This enormous stem, with its colosial cluster of branching blossoms, takes only a few weeks to grow ; and as it rises and flowers, or still more as the immense capsules ripen their seeds, the bases of the leaves, once swollen and thick, become by degrees flaceid and empty. The stem and hlossoms have drained them dry. At last, as the seeds fall, the whole plant dies away, having used itself up for ever in 
its one great act of flowering, just ats the egg-laying rose-aphis uses itself up in its orgy of motherhood.

Now, this is much the same as the way in which soldanella behaves, exeept that soldanclla continues to flower, spring after spring, for many years together. It does not exhaust itself in a single blossoming. Otherwise, the two plants, though so different in size, behave in much the same gencral fashion. For asave must necessarily evolve a great deal of heat during its rapid flowering period; but this heat is useless to it, as heat, just as the heat we evolve in rumming a race is, as such, of no advantage to us. The main differcnce here is that soldanella has need of the heat and employs it deliberately for its own purposes. In the struggle for existence, every point of advantange any creature possesses must tell in its farour, and the soldanellat has thus been enabled to hold its own hravely in the intermediate belt at the margin of the ice-field. But its limits are narrow. In the open ground it is soon lived down by more hatrdy kinds, which rise higher into the air; its range is almost entirely bounded by a marrow belt just where the ice is melting. Above that point it cannot grow; below it taller cnemies soon oust and dispossess it. It utilises its short time between these two impossibilities.

Strange as it sounds, too, the ice itself acts ats a sort of protective blanket or coverlet to the trustful soldanella. Only a plant that could pierce the ice could ever hare hit upon such a paradoxical mode of warming itself by its own internal com- 
bustion. If a herb that flowers in the open were to make experiments in warming itself in the same manner, its attempt would necessarily fail, because as fast ats it heated the air the wind would blow the heated portion away, and the plant would therefore derive no benefit from its expenditure of fuel. But we all know how Esquimans can live in a snow hut, keeping it warm inside by their own breath and the heat of their bodies. It is just the same in principle with the soldanella's icecave. The little dome or carern gets warmed within by the respiration of the tlower-bud ; and the heat thus produced is retained within the walls of the cavity. It is almost as though a mouse or other small animal were to try to bore a path for itself through an ice-barrier, not by gnawing the ice, but by breathing upon it slowly till it melted.

See, then, how absolutely the soldanella behaves like a man who is making a conservatory. It lays by fuel for the stove in its leares to keep its flowerbuds warm and to force them in spring, at a time when they conld not blosisom without the artificial heat thus supplied them. It keeps in this heat within a transparent covering, the doors of which are never opened. As for light, that reaches it through the crystal summit. But it employs the heat also to bore its way out ; and, as its ultimate object is to get its young seeds fertilised, it finally pushes its flowers ont into the open air, where they may receive the attentions of the fertilising insects-just as the gardener does, without knowing why, when he wishes seed set. The pendent bell- 


\section{A Plant that Melts ICE}

shaped blossoms, again, even after they open, are admirably adapted for keepins in the heat ; and they are also exactly fitted to the shape and size of the hees and thes that act as their chartered carriers of pollen. A plant, in short, hats to accommodate itself at every point to the needs of its situation; it has to secure for itself a firm foothold in the soil, and a due share of food from the surroundings air (for its diet after all is chicfly gaseous) ; it hats to take care that its pollen shall be cluly dispersecl, and its seedlets fertilised ; and finally, it has to see that its young are satisfactorily settled in the world, and deposited on likely spots where they can germinate to advantage. It must be a sood parent as well as a prudent and cautious adrenturer.

The strugsgle for life carried on under these circumstances lats slarpened the wits of piants (1) a far higher degree than most people imasine. Pants have developed almost as many dodges and devices for securing food or avoiding enemies as animals themselves have; and this single instance enables us to see with what forethought and cleverness they often provide asainst alderse chances. Soldanella, indeed, could! not exist at all upon its ice-clad heights if it did not lay up food and fucel in summer against the needs of winter, like the bee and the ant ; if it did not hurn up its own fat for warmth, like the dormouse; if it did not tumnel the ice as the mole tumnels the earth ; if it did not retire beneath the snow-sheet on the approach of winter as the queen wasp retires into the shelter of 
the moss when frosts begin to kill her worker sisters, or as the squirrel retires into his hole in a tree at the approach of December. Ancestral instinct teaches the one just as much as it teaches the other; and those who have closest watched the habits and manners of plants have the highest respect for their industry and intelligence.

Looked at from this point of view, we may consider indeed that every seed, bulb, or tuber is not merely a reservoir of material for future growth, but also a reservir of fucl for supplying the heat necessary to the first stages of sprouting or germination. And without claborating this question further, I may add that if you will examine closely many early spring buds and flowers, especially such as willow and hazel catkins, you will find not only that they are formed over winter and enclosed in warm overcoats to protect them from the cold, but also that they grow in spring before the air is warm enough to stimulate growth directly--or in other words, that they depend in part for heat on the consumption of their own internal fuels. 


\section{I I}

\section{A BEAST OF PREY}

7 HE lion, we all know, is the king of heasts ; a Tippoo Sahib of the desert, he treats his subjects with the simple and unaffected cruelty of an Oriental monarch. The tiger is aiso a somewhat ruthless animal ; he prefers to eat his dinner living. But for sheer ferocity and lust of blood, perhaps no creature on earth can equal that uncamny brute, the common garden spider. He is small, but he is savage. Lions and tigers are credited at least with the domestic virtues; if we object to the king of beasts that (ats Thersites said of Agamemmon) he devours his people, we may be told in extenuation that, like Charles I., he is a good hushand and a model fatler. No such plea can be urged in mitigation of the miscleeds of "tat bloodthirsty wretch, the female spider. Not only does this Messalina among small deer poison, and then eat, her prey, but she also often kills and makes a meal upon her own lawful spouse, the father of her children. In selecting a sarden spicter of my acyuaintance, therefore, as a theme for a short 
hiography, I do not clesire to hold her up to the youns, the say, the siddy, and the thoughtless as a pattern for imitation. She does not point a moral with the ant. On the contrary, she must rank with Semiramis and the famous queen who dwelt in the Tour de Nesle as a shining example of abandoned and shameless wickedness.

Spiclers are not all alike. They are of many kinds, and of various families. So I shall begsin by remarkings that Rosalind, the particular lady whose portrait I hare here presented to you in words, and whose life-history my colleague, Mr. Enock, hats drawn for you from nature, belongs to the most familiar race of her kind, the true garden spider, which constructs the best-known and most perfect examples of regular geometrical webs. We called her Rosilind because she was a maiden of hunting proclivities, who lived under the greenwood in our own particular Forest of Arden. But her ways were not lovable. She killed flies in a fashion that would have brought up fresh tears in the eyes of Jacques; and she devoured her Orlando with all the callous ferocity of a South Sea lslinder.

I will hegin at the beginning with my eightlegged friend's hiography. Rosalind was hatched in spring from a cosy cocoon or ball of eggss deposited by her affectionate, but otherwise cruel, manma in the preceding Oetoher. She was one of a large family-say, seven or eight hundred. The cocoon was composed of yellowish 


\section{A Beast of Prey}

silk, and attached, as the furst illustration shows

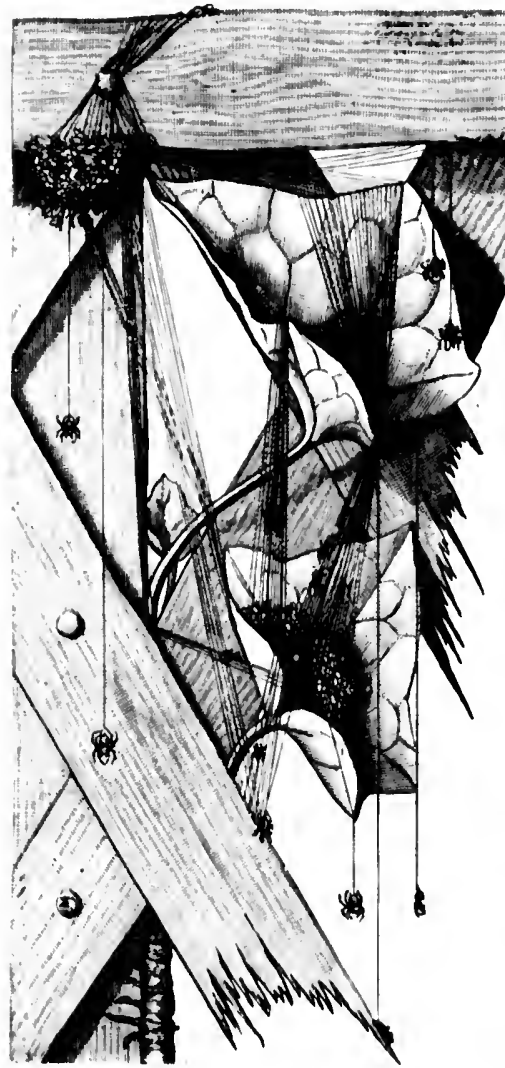

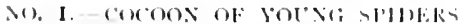

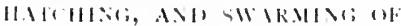

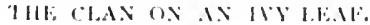

you (No. I), to the under side of a piece of tretlis-work, against a cottage wall, partly wergrown with ivy. Within this snug abode the tiny eggs, each wrapped in its own internal coverlet, escaped the cold of winter, and hatched ont in early spring with the first hurst of warm sumshine. It wats a bright May morning when they ventured abroad. The tiny spiclers, just freed from their shell, with its onter sreatt-cuat, let themselves down hy short wehs to all iry-leaf helow, where they chnstered for a while, after the yueer fatshion of their species, in a sort of 
close-knit crèche or communal nursery. Gathering together in a compact ball or mass, like bees when they swam, the wee creatures began hy spinning in common a covering of thin silk, in whose mickst they lay rolled up in an apparently inextricable tangle of legs and bodies. 'That is the universal fathion of young spiders of this kind. But if you touch them with a straw, a strange commotion takes place all at once in the crowded home. The mass unrolls itself. The six or eight hundred small beasts within wake all together to a sense of their responsibilities; the ball, which looks at first like a cherry-stone, divicles as if by magic into so many eager and frightened animats; and the spiderlings disperse like the nations at Babel. Each goes his or her own way helter-skelter, in search of a suitable place to commence operations as a general flycatcher; and in two minutes the space around is fairly colonised by spiders, who set their snares at once with excmplary industry. 1 am glad to be able to give them credit for the one good quality they do really possess; though $1 \mathrm{am}$ aware that in their case inclustry is often only another name for consummate greediness.

From the general gathering of the clan in which our Rosilind thus took part she was ruclely roused by the touch of such a straw; and, emerging in haste into the open world, the great, cruel world, amidst whose temptations henceforth she was to earn her dishonest livelihood, sle cast about her for a farouring breeze to waft her first-spun threads to some lucky position. It was a delicate operation. 
Balancing herself with her eight legs on the edge of an iry-leaf beside her native corner (ats you see her graphically represented in $N_{0}$. 2), she span, to begin with, a few short ends of silk, which she exposed to a passings current of air by tilting her back up in her most persulasive manner. Where the silk eame from, and how she managed to spin it, we will incpuire hereafter ; for the moment, it must suffice to saly that the wind was polite enough to fall in with lier wishes, and to waft one of her threads to a secure position. There it gummed itself automatically hy its own stickiness. Mr. Enock, who timed her, reports the interval she took in fixing this first thread as thirty-six seconds. The cable itself wats drawn out from Rosalind's spinnerets hy the foree of the wind, as she stood with her head down and her body protruding; in little more than half a minute she was climbing up a line fifteen inches long, which had caught and glued itself on the edge of a jasmine leaf. For the silk is sticky and riscid, like the glue of a mistletoe, when first produced; it only hardens as it ciries, so that it can be readily moored in its first state to whatever it touches. You may compare it in this respect to hot sealing-wax, or to the early pulled stage in toffee-makings.

In No. 3, asain, we see Rosalind's first snare, constructed neatly, with the usual arehitectural and geometrical skill of her race, hetween the twigs of the jasmine bush. In the centre she sits, as is her wont, head downward. The method of making this snare is so interesting and curious, 
however, that I shall describe it at some length, with needful explanations.

Rosalind hegan by letting the wind fix an original base thread, pretty much by accident. As soon as she was satisfied with the lie of this, she formed a

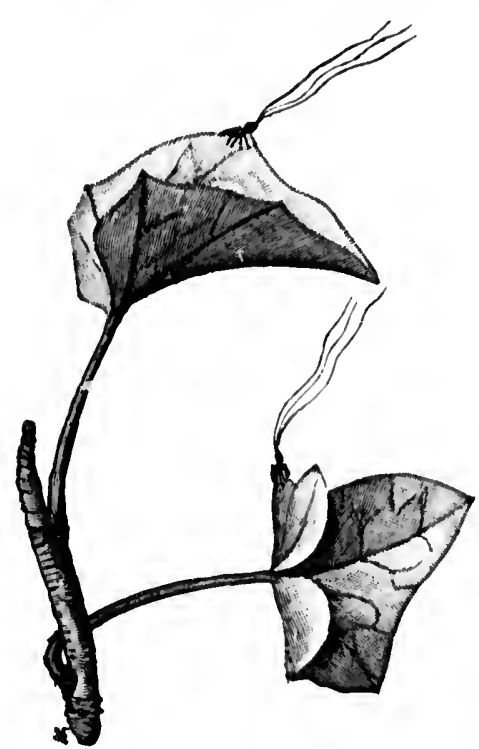

NO. 2. -YOUNG SPDERIINGS CASTING THEIR HIRST TIIREAUS TO CATCH THE WINI. few others about it irregularly in a rough pentagon, as you see in the outer part of the weh, merely to serve as a scaffolding for her future operations. But as soon as she had formed a careless angular figure all round the sphere of her projected suare, she let down a perpendicular thread from the top of her base, through the centre of her predestined home, and fastened it off at the hottom by glicling down it as she span it. Then, walking up this first ray-line again, she set to work once more a little to the right, spinning again as she walked, and fastened a second ray from the centre of the first to one of her outer cahles. Next, time after time, she walked back to the centre, ran along the last ray made, trailing a thread as she went. 
and fastened each new line taut to one of the outer scaffoldings. So at last she had formed a regular set of rays like the spokes of a wheel, but as yet without any spiral connecting threads or meshlike cross-pieces. The rays of this first frameworkwere stout and thick, comnposed of several distinct strands, but very little viscid; they were built up of many threads each, in a manner to be hereafter described ; and they hardened quickly on exposure to the air, for they were intended mainly to serve ats heams, not as nets or insect-cateliers.

Her ground-plan being thus complete, Rosalind next proceeded with great deliberation to add

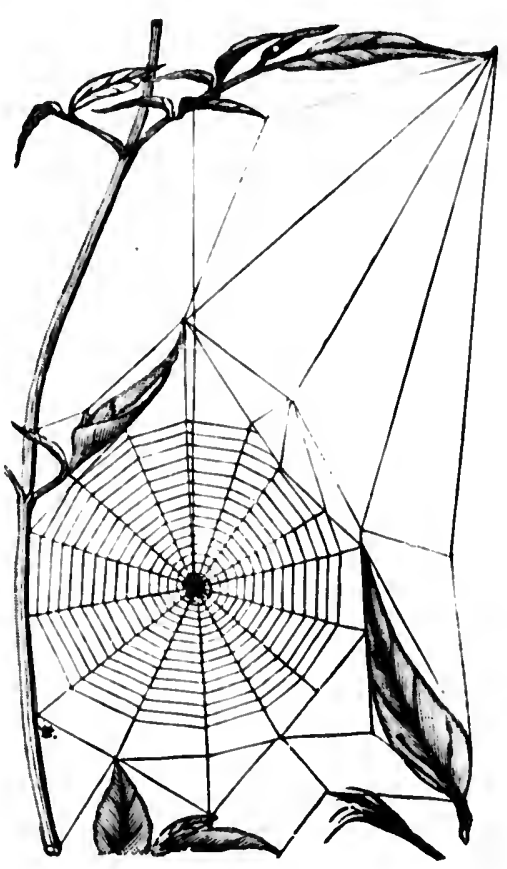

No. 3 -A HAHY SPIIlik IN JTS FIRST SNAKE. the meshes of the web (which are the practical insect-catchers) by connecting the rays with the spiral network. ln doing this, she followed a regulat method. Begimning at the centre, she fastened a thimner cord 
to one of the spokes, and worked slowly outward, fixing the line to each ray as she went by the aid of her hind legs, which are almost hand-like. Then, reversing the process, she fastened another thread to one of the outer cables, and carried it back through the spokes in a similar spiral to the hub or centre. These two spiral threads are the ones which she specially designed for catching her prey; they are thinner than the spokes, but are closely studded through all their length with tiny drops of sticky stuff like bird-lime, admirably adapted for snaring insects. You can see the drops, if you look close, even with the naked eye; and they are very elearly visible by the aid of a pocket-lens.

How is the weh itself manufactured and produced? What is its raw material? Well, to answer that question I must give you here some brief description of the personal appearance of Rosalind and her sisters. The garden spider, you know (and as you call see her in No. 6), is at great, soft, eight-legged creature, about half an inch long, though her comparatively insignificant husband is very much smaller and less conspicuous. She consists, in the main, of two parts, the foremost of which, though it rejoices in the scientific title of the cephatothorax (science is always so careful to give things nice easy names while it is about it!), may be more popularly described for most practical purposes as the head ; and to this large compound head are attached the eight long-jointed, hairy legs, with the muscles 
that move them. The other half of the spider consists of the abdomen or stomach, a soft, round bas, quaintly marked like a quail's head, and very squashy in appearance. With this last part of herself, the garden spicter spins her snare or weh out of the mannfactured material of her own hody. She spins it of her own digested contents. And ats she has freguently to mend the web after various mishaps, which oceur in the natural course of business-as when it is broken by the wind, brushed against ly passers-by, or torn and mangled by a big fly or wasp-you can readily understand that she must eat in proportion; which is, no cloubt, the true cause of her almost incredible voracity. In point of fact, a healthy female spider spends all her time in catching prey and eating it.

In No. + we have a greatly enlarged back view of the spinnerets from which the threads are produeed, and a still more enlarged side-view below of the separate little ducts from which the component strands issuce. According to circumstances, she makes her threads simple or componnd. The sticky fluid of which they are formed is secreted by powerful glands in the ahdomen; it is then squeced out through numerous minute tubes, of different calibres, and hardens in most cases when exposed to the air, though the spiral threats with the insect-catehing drops on them maintain their riseid nature much longer, so as to gum the flies down, rather than entangle them in meshes, as with the common house-spicler. 
No. 5 shows us further details of some other interesting features in Rosalind's anatomy. The upper figare represents three distinct varieties of the viscid threads,

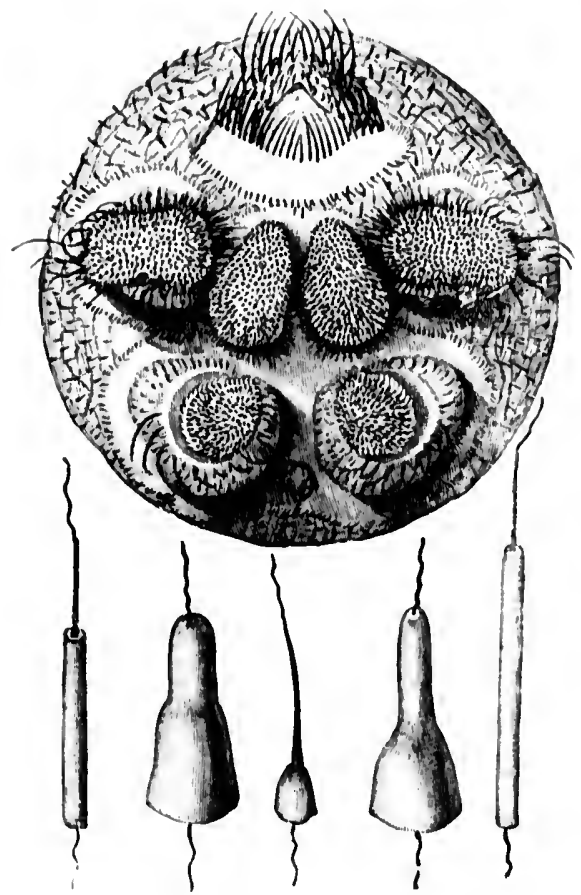

No. 4.-BACK VILW OF ROSALINI SINNIKl:Is. each with its own peculiat type of heads, adapted for catching latscr or sillaller insects. Every kind has its own heads spread for it. 'The flies get entangled in these, according to their size; and then, tearing the web to free themselves, find the coils only double round their less and borlies.

But the spicler does not content herself with merely catchings insects ; she poisons them as well. Wie had not watched Rosatlind long in her chosen hir hefore we discovered that sle diel not live in her seometrical web; that was nerely her lunting-net; her private residence consisted of a smug little cell 
or nest, under shelter of a rose-leaf, at a few incles' distance from the centre of the snare; and in this quiet home it was her habit to rest unseen, under cover of the shady leaf, until prey came within measurable distance of her sphere of practical politics. But she kept up communications with the seat of war. From the centre of the snare to the nest slie had stretched a stout, thick line, along which she conld run easily on the slightest indication of a prospective victim looming up in the background. Moreover, this cable or thread seemed to be comnected by its clifferent strands with so. 5.-visun tureans, WiTh various parts of the snare; at any rate, it acted as a telegraphic
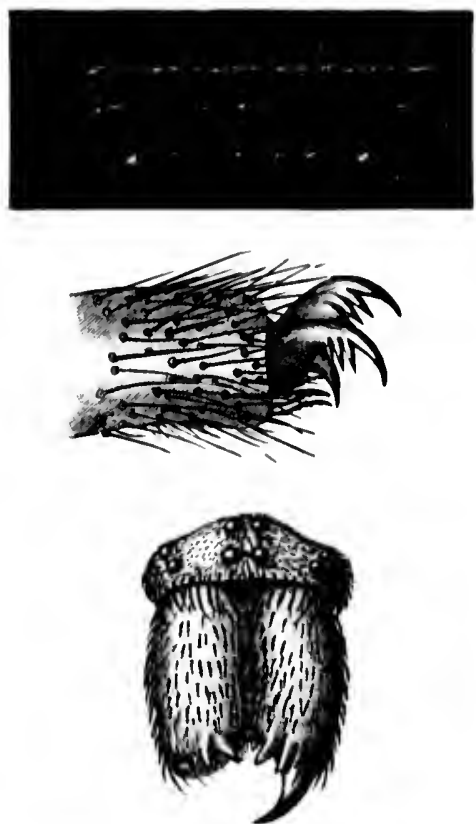

SICKY IBAIM ; FOOT AXI) CIAWS OF SIIIFK ; SIIUFK'S FACE, WITH

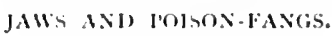

communicator between the home, strictly so called, and the place of business. For Rosalind used always to recline at her ease with one hand-like claw placed steadily on the line of communica- 
tion; thus seated, she would watch with cat-like stealth for any chance of a victim. The moment a fly tonched the suare, however lightly, it would set up a slight tremor of movement in the indicatting thread; and, puick as lightning, informed by touch of its whereahouts, out Rosalind would dart, ready to go straight to the spot and suck that luckless creature's life-hlood.

Besides, the bigger the tly or hee, the harder it was likely to struggle; and Rosilind noted well, hefore starting, the comparative extent to which the line was comvulsed, and governed herself accordingly. If a big bumble-bee or wasp fell peradventure into her coils, he plunged exceedingly ; and Rosalind, prudently aware of the expected sting, approached the clangerous prey with marked reserve and calltion. But when it was only a harmless small thy that struggled in the net, she rushed forth from her lair as hold ats brass, seimed the body with elaws and jaws, and sucked the poor thing dry in less than a minute. Then she flumg away its empty skin, or cut it contemptuonsly out of the weh it had injured.

A glance at the second figure in No. 5 will show how admirably the spricler's foot is adapted for all these various purposes. Adaptation could hardly go further. The spicler hats claws with which she can hold her web like a hand; and she has also sharp nails which aid her not at little in manipulating hee prey and her web. But she has more than all these: the daws themselses, yout will note, are provided with toothed or comb- 
like edges; and these curious saw-teeth are useful to the spider both in arranging her webs, in weaving them tight or loose, and in fecting the line of communication, when at rest, for indications of a captured insect. If youl remember that the spicler has no less than eight legs, each somewhat differently provided with special clatwis and combs, you will molerstand how formiclable: at heast she really is to ereatures of her own size or smaller.

But beneath the foot in No. 5 are represented those still more terrible orsins, the mouth and poison-fans. The face is shown, end on-a fullface portrait; and the little knobs above ate the cight sharp eyes with which the spicler looks out for its prey when eaptured. Below lic the jaws, with their two movable poison-fangs, one of which is open, while the other is folded lack into its sroove or receptacle like a kitten's claw. This poison-fang is supplied with renom from a gland in the head. When the spider catches an insed and desires to ealt him at once (ats she generally does if he is not very lange) she poisons him outright, and proceeds to derour him. So she often does with a wasp or other dangerous insect. But if she wishes to preserve him for future use, she quictly envelops him in a network of weh, and kecps him in durance vile, as I shall show you latce - a prisoner awations his turn to be killed and caten. 'Taking her ats a whele, therefore, the

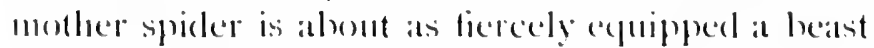
as creation can produce: a monster armed like the 
tiger and cobra combined; with the claws of a lion and the poison-fangs of a serpent; both which she supplenents by a treacherous snare, itself a monion of the net and the bird-line trap. No wonder, with such an armomy, that she has prospered exceedingly in the struggsle for existence. And, indeed, you will find garden spiders wherever you go. They are one of the most successful types in creation.

We watched our Rosialind closely through the whole of a season. It was a curious drama of blood and treachery. For the most part she lay eoncealed like a secret assassin in her nest behind the rose-leaf, seldom spreading her net in the sight of the vietim; but sometimes, assuming the role of highway robber, she would bolkly rest in the very centre of her snare, with her head clownward, waiting for the approach of castral small insects. At such times, we noticed the lareser and more intelligent flies uswally gille her a wide berth; she seldom canght bluchottles or hees on these occasions of open displaty; hut tiny gnats and midges, less careful or less wise, would get entangled in her weh, and at these she would rush out viciously, sucking them dry then and there, and rejecting their empty skeletoms with lordly meoneern. Her appetite was moboumded; hut she grew so quick, she had so often to remale or repair her broken strare, and she was laying hy so constantly for her materual functions and hee cight houdred eggst, that this dicl not surprise us. The web, indeed, was often torn by wasps or large tlies out of all 
recognition; and at other times it was destroyed by the honsematicl or the satelener. On an arerage, I should say, Rosilind had to rehuild the whole concern abont once in three days; and as she wats obliged to spin it all ont of her own boly, this came very expensive. We noticed, howerer, that she was economically minded, for sle wasted no web; 1 think she ate ilp all loose ends or remmants: and the central portion, where she occatsionally reposed on the look-ont for prey, wats free from the riscid beads which elsewhere adorned the cross-pieces. You sece, this part of the structure was of comparatively small service as a snate, while the sticky stuff would have interfered with her own freedom of movenuent. She usually avoided the headed spiral, and only ran along the stouter spolies or cables.

But the most wonderful secene of all was witnessed when Rosilind found in her net a large wasp or a blow-tly. On such oecatsions, she wats sencrally resting in lice nest moler the rose-leat, with one foot held firmly on the eord of communication. If a light pull only cante, she would rush widlly forth, and seime in a fren\%y the small fly that caused it. She seemed as if drunk with lust of earmage. But when the strength of the pull showed ber that a latge bee or watsp was struggling in the web, she would atet in various ways aceording to the needs of the moment. Wasps she approached, we noticed, with considerable fear; she knew their dangerous nature. But sle was seldom afraid, even so, of tackling them; though at times, 
if a very latse and truculent specimen got entangled in the wed, she seconed to despatir of landing him. In such calses, she would ent him ont bodily, by hiting the threads, and let him drop at

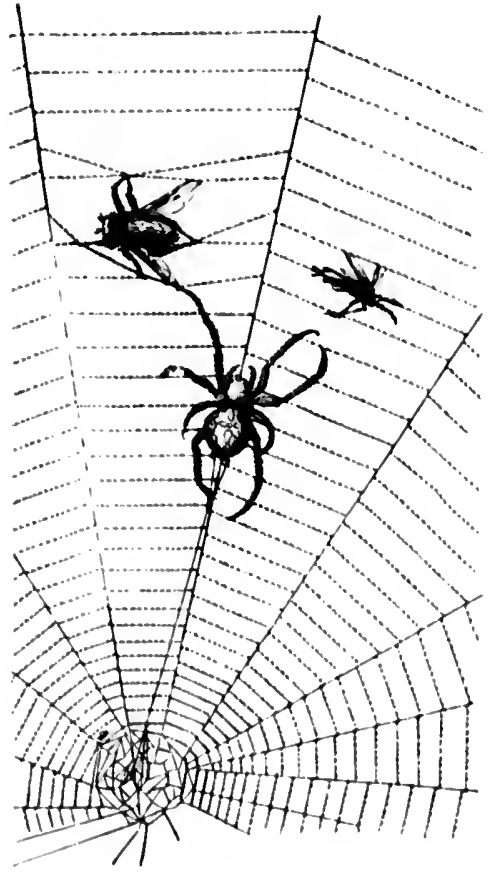

NO. 6.- ROSAISMU OX HER WAV IO

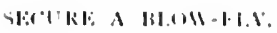
once, thankful, like Dogherry, to he rid of a knawe. A moderate-sized wastp, however, she would rush out and attack in that frenzy of rage and lumeger, at sort of mad, blind rasge, which one often notices in lierece carnivorous amimals. She would heusin her onslaught neat the victim's head, aroiding his sting, and envelop lim in web, till his willgs were pinione: ; then she woulil cantiously approach nearer and nearer to the tail, but give the actual sting a wide berth till the conclusion of operations. The wasp, meanwhile, would keep protruding his poisoned lance in evident fury, striking wildly at the air ; while the spider continued to suck him dry yuietly, from the head backward, 
without the slightest consigleration for his fectings an a living animal. I may atd (to anticipate an obvions criticism) that I ant alwathe the stins-bearings wasp is a female; 1 hatie only treated her here to a matsculine pronomu hecallse it helps to) discriminate her hetter in each sell. tence from my friend Rosialind.

In No, 6, our intrepid Rosialind is re. presented in the act of attackings a blowty which has bur.ed noisily into the web. The moment her delicatte foot on the line informs her that a large insect has got entaugled in her toils, she rushes angrily. ont, and longins at once to envelop him. In this case, howerer, lece intention is not to devour him on the spot; she means to

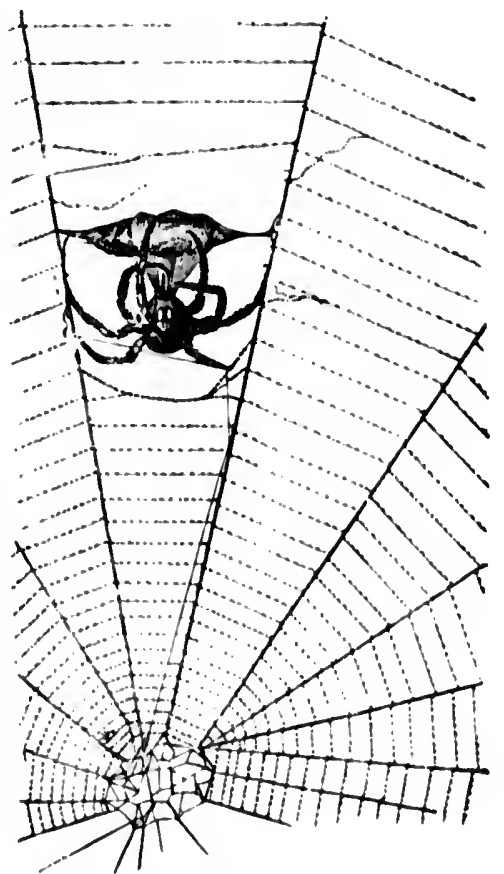

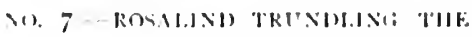

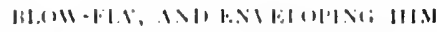

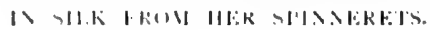
store her larder wible provisions for future ase, and is ats carceless as ever of the feelings of her rictim. No. 7 shows with what biands she proceceds to swathe him. She catches him tirmly at fatst ats 
she can, so as to prevent his furious struggles from mnnecessarily destroying her precions weh; then she trundles and bundles him rapidly in a sort of treadmill or merry-go-round, with her front pair of leess; holds on to the web and steadies herself with her two middle pairs; and uses her hind pair, with her comb-like claws, to distribute the silk which she winds in coils ahout his wings and boly. You can see now how useful are her eight legs to her. Each fulfils its own function. In about a minute she has twirled him round and round, and swaddled him firmly in a strong silken covering. 1 regret to saly she does not then proceed to eat him at once, hat keeps him imprisoned in torture for an indefinite perio.l, tightly bound in silken cords, till she desires to dine off him. The unhappy tly is bound hand and foot-or, rather, wing and leg-till it is absolutely incapable of the least resistance; it is then kept in its close prison with a cruclty more than medieval, and at last devoured alive piecemeal by its ruthless captor. The morals of spiclers are scarcely better than those of Chinamen.

Rosalind's changes of costume were also most theatrical and interesting. Lilie her namesake in the play, she appeared every now and asain in a different suit of chothes, and rejected her old ones. The manner of making the new suit, however, and of shuffling off the old, was extremely interesting. She moulted periodically; but at each moult the whole external skeleton was sloughed off, like a snake's skin 
or a lobster's coat, entire ; and a new one srew under it.

In No. \& Mr. Enock has luckily caunght our heroine just at the moment of such a moult. She is dropping out of her old skin, hy means of her threads; bencath it, the new one has grown, the animal being thus quite literally accommodated with a fresh suit "while you wait." The waty the old skin lamgs up is curious and typical. At lirst the new outer coat is soft and yielding, like the freshly moulted skeleton or armour of a crab or lobster; but it soon hardens, and not infrequently advantage is taken of the moult to replace parts that have been accidentally lost (or broken off, such as

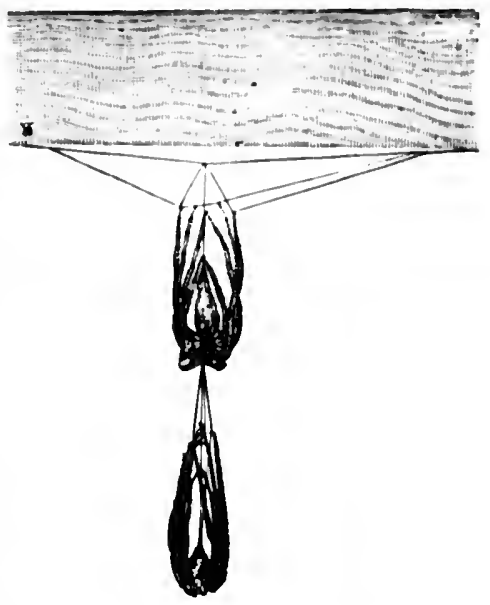
a leg or a feeter. The eeonomical spider, however, never wastes anything: she does not throw away the old suit; as soon ats her jaws have grown hard enough, it is eaten up by the owner, and thus used over again in the production of wel of hody material. If thrift he a virtue, no beast on earth possesses more thatl a spider. 
I nave left to the last the delicate question of the domestic relations of spiders, which are certainly mot of a sort to he commended for imitation. The lady spicler, incleed, ton closely resembles the late Mr. Deeming and the matives of Fiji in her unsatisfactory notions of conjugal affection. I regret to saly it is her reprehensible hahit to devour alive her mosucecsiful suitors, and sometimes also the father of her own childien. 'These are mamiable trats, but 1 must not conceal thems. You will observe, no dombt, that thromshout I hate sad comparatively little of the masculine spoder, and much of his latly; and I hated done this of set purpose ; for spislers are a sromp in which the domimance of the females is mated and moncleniable. The matriatrate prevails; the females are the race, and the males exist only as la\%y diones, mere idle fathers of future senerations. This heings so, the mother spicler, true to her thrifty icleas, regateds them in the light of necessary evils; and heing always economical, she thinks it well to atilise them for the purposes of the rate hy eatims them mp the moment they have fulfilled their sole and sinsle marital function.

This peculiat habit makes the courtship of spiders a srim trasi-eomedy, well worth observing. In No. 9 Mr. Enock has represented one salient secue in the painful clamma. And this is the interpretation thereof. Two male spiders have eome to pay their conte to the supereilious Rosialind. She, good lady, sits muconcerned but watchful in the centre of hub of her strare, appatently 
careless of the two eager postulants for her hand ancl beart, but in reality observing them witl critical eyes, and ready to rush ont and devente them if they bail to please laer. The gentlemen, accordingly, lave to be very atful. They (s) through strange antics. Now they approatch her cantionsly, very much on the alert, ready to pull the strings and advertise her of their presence, but also prepared to) turn and run, or to cust the line and drop, if she does not regard theje advances witl farour. Now asain they retreat, alarmed at lier ispect. Rosalind sullis in her web, and Ints to sece which of the fwo

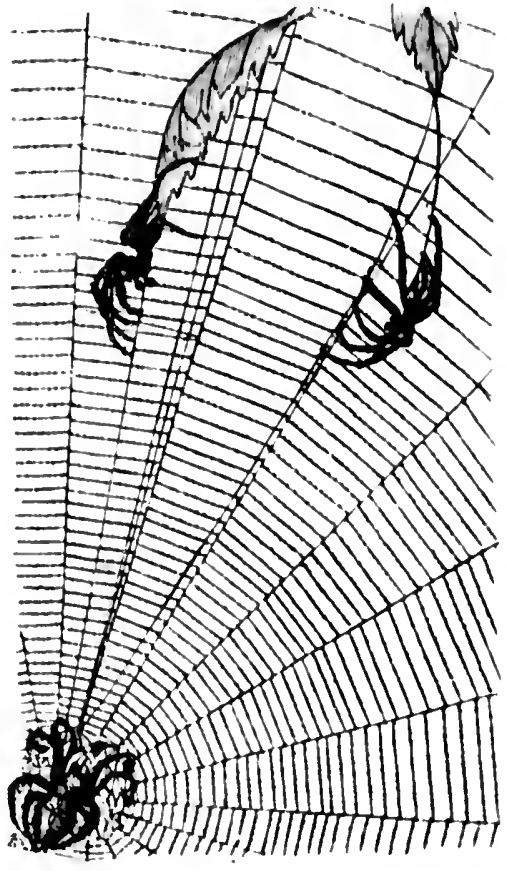

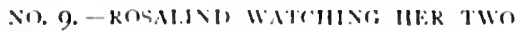

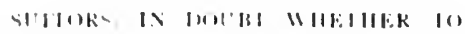

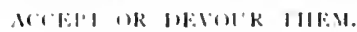
she prefers, if either. Shomld the fit so seime her, she will aceept one or other of her ardent suitors; but should she happen to he humsgry of else to be disappointed, or in an ill-humonr, she nuay 
dat out upon them at once and make a meal offhand of lice devoted admirer.

Even the stacessful suitor himself is he 110 means safe; for it is Rosalind's way, when sle tires of a lover, not to nass and quarrel, but to devour him outright, and look out for another. This saves time and trouble, and is better in the end for the temper of the species.

When antumn comes, Rosalind lays her eggs in a cocoon, and fastens then on the uncler side of a stone or piece of wood, where they hatch out in spring, and so the whole story of her life begins over asain. Sle herself, meanwhile, retires to winter yuarters, where she passes the cold months under shelter in a state of more or less torpidity. It is not known exactly how long a spicler lives; but they continue for at least two or three years, and probahly nutuch longer. We had Rosalind under examination for two suceessive summers.

The family to which Rosalind helongs, that of the geometrical spiders, may be placed at the very head of the whole spider order. Its webs are the most perfect in architecture, are the hest planned as snates, and have a strict monopoly of the sticky heads, which help to entangle the prey, and which are also, under the microseope, most beatutiful objects, decked in prismatic colours, and looking like so many irideseent opals. In shape and markings these spiders are also superior to the common run of eight-legged beasts, though they are certainly less beatutiful than some of the lovely green and variegated semi-transparent lield-spiclers. It would 
not be going too far to saty that the geometrical weh-makers are the most advanced and civilised members of the entire soroup. For there are degrees of evolution among these humbing carnivores. Some of the least advanced kinds merely stalk or hunt down their prey on the open. 'These lower savases amoms the spieler tribe lurk under stones or in the crevices of hatk, and rush ont at their victims, or spring upon them mawares. One may compare them to such low hunting human races as the natives of New Guincat or the North American lndians. Others, again, construct tubes, with or without trap-cloors, and catch their prey more or less cumningly near the entrance. Yet others, once more, wealve irregular webs, among leares and twigs, or in the corners of rooms, and trust rather to mere meshes than to sticky substances. But the seometrical web-weaters, the most advanced of their kind, have learned by the experience of ages how to construct a regular sllare, on a fixed siromel-plan, and to supplement it by a singulat trick of beady hircl-lime.

Even among the geometrical weh-weavers themselves, again, there ate marked varieties of progress and culture. For some kinds have only three claws to each foot, while others have more; and there are certain species which posiess in addition a sort of opposiable thumb, so that they caln catch things ats with a hathd, fecling them all rommd, and grasping their threads as a sator grasps at cable. Such opposalhe thmombs alle always atecompanied hy high intelligence, as one sees in 1nan, 
in the monkeys, in the opossim, and in the parrot.

Indeed, all romind, it maty be safely said that the spiders ats a group stand at the head of the animals with jointed bodies; and that the geometrical tribe in particular stand at the head of all the spicters. Nor must we eomsider that their cruelty and ferocity put them out of court in this connection ; for man himself, taking him in the matss, is one of the most ruthless of animals; and the bees, which hy universal consent rank among the highest insects, ale the group which most minersally slatghter their own brothers, the drones, as som ats the commumity has no further use for them. The fact is that Nature ats a whole is intensely utilitarian; each kind fights for its own hand alone, and regards as little the feelings of other kinds as the fisherman regatrds the feelings of herrings, or as the fishmonger minds the objection of lobsters to be boiled alive for our human convenience. A rate that skins living eels at Billingssate, and clecks its hats with egrets in Hyde Park, has no just ground of eomplatint, after atl, agatinst my poor, misguided, husband-eating Rosalind. 


\section{IV}

\section{A WOOLI,AND T'RAGIIDY}

$\mathrm{N}$

ATLRE is rich in trageclies ; but somchow, the trageclies which are long familiat to us ecase to be trangic. We aceept them as merely picturesque little episodes in our daily existence. Nobody is astonished, for example, when a cat plays with a mouse before killing it; nor when she teaches he altentive kittens how to let it go in spont, manimed and half clead; it does not shock us when the poos clazed little beatst, thinking the danger orer, matkes a wild hurst for freedom, that she shows them how to pat it with one cruel paw and still further clisable it. Facts like these are too commono and too long known to appeal to us strongly. We note them with a very languid interest. But when people lirst learn some mufamilian example of Nature's cruelty, I almost always find they are profoumdly struck by it. The norelty of the case sives it vividness and makes it sink in deep. And I know no instance which impresses the ordinaty observer so much at sight as the first time when, wandering accidentally through some peaceful eopse or wood, he linds himself face to 
fatce with that hateful hoard, at hutcher bird's latreler.

For what the eall does with the mouse for a few short moments, that the butcher-hird does with it through long lingering days and nights of atsong. He impoles his momse alive on the stout thorn of some may-hush, and keeps it there, maimed but strussinge, or slowly dyins, for a week at at time, mutil he hats need for it as food for himself or his family.

A clever artist elevised a coser for once of our popular scientific papers many years ago, which enforecs well the miversidity of this ceaseless struggle of kind against kind, each wholly regard. less of the other's feelings. In the centre foregromud, a fly flits airily over the surface of a river, seatehing for its mate in the full joy of existence. Bencath, a small fish jumps up at the 1ly, and seems in the rery act of seizing and swallowing it. Behind and below, howerer, at pike lies grimly in wait for the small fish with open mouth; but he is anticipatted by a kingfisher, which sllatches it from his jaws hefore they ean close osere it. In the background above, a hawk poises ibself on even wings, ready to swoep down in trimmple at last on the suceessful kingfislier. There you latse the epic of anmal life in hrief; you hatre only to throw in an angled on the bank, fishimg for the pile with a lise-hat of mimmow, and an enthusiatstic ornithologist pointing his fowlingspiece at the rare species of hawk, in order to complete the whole cyele 
of slatughter. And observe that each actor in this drama of death is as carcless as to the life he salcrifices and the pain he calleses ats the angled is carcless ats to the foelings of the minnow he impales 11 pon his harbed hook, or the sportsman is carceless as to the feelings of the happy hirds be hrings down with his cartridges.

Nerertheless, when we come across one pasge in this vast mute tragecly of sentient life among the calme surromolings of a quiet wood, it always smprises us afresh; and that is why I have chosen as a goned illustrative case of this phase in nature my wicked old friend the shrike, or butcher-bircl.

Externally, I do not know that there is anything about his personal appearance which might lead you to suppose he was much wickeder or fiereer than the rematnder of his family. In costume and colouring he is quict and demure, mot to say almost quakerish. To he sure, there is a harking gleam in the corner of his eye, when you get a close riew of him, which betokens a crafty and crucl dispessition; while something ahout the peculiar curl at the tip of his beak sems to sugsigest a lordly indifference to suffering in others. lint on the whole he is a hypocrite in his onter desss ; you womld hardly sospect him at first sight of the high erimes and misdemeanomes of which I achit him to he really stiilty. Still, you do not knew at thrush till you have seen him eat worms alise slowly, a montheul at a time, pulling them ont of theip holes and 
chewing them gradually as he goes; and you do not know a butcher-bird till you have lighted upon him at home in his woodland haunts, with his living and writhing larder collected all round him.

In size, the butcher-bird (No I) is about as large as a lark; but he is a stouter and handsomer

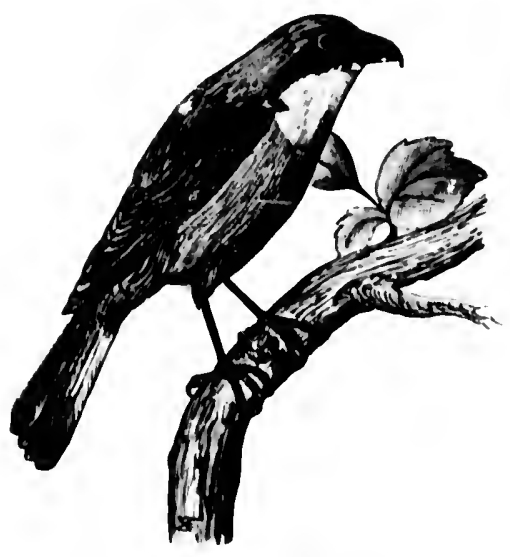

No. 1. THE HUTCHR.K-MRH. bird, especially in his fresh spring plumage, when he goes a-courting, and wins his soberer bride by the beally of his cont and the gallantry of his hearing. His colouring is fine, but somewhat diff cult to describe, his recognised specific name of "the redbacked shrike" being perhiaps too strong for his actual hues.

Chestnut, shading into reddish brown above, would be a more accurate mode of stating the facts; but he is pinky-white below, and has dashes of blue, of grey, of pure white, and of black seattered about in various parts of his plumage. A hright black hill and a dark hazel eye add beally to his sharp and vigorous comntenance. Alertness, indeed, is the keymote of his chamater.

As in most dominant races, his lady differs 
much from him. She is duller and darker, and lacks the occasional white patches that adorn her lorel. But she shares his general air of keen life and his rapidity of morement, being in every respect a helpmeet for him.

Mr. Enock has represented leer in: No. 2 in a characteristic attitude, perehed on a small twig

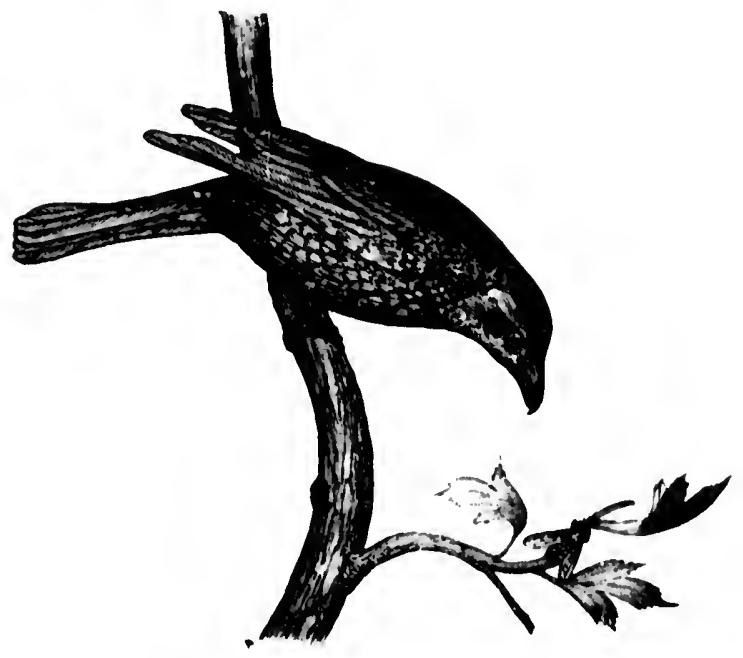

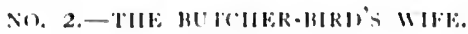

of hawthorn, and ready to pounce down upon a huckless Hy, whose mosements she is watching with interested attention.

I saly hawhorn on purpose, for the peculiarity of the butcher-bind is that in England or abroad

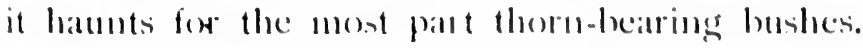
With as, it is but a summer migrant, occurring 
pretty frequently in the southern combties; but its winter home is on the Upper Nile and in Eatst and South Africa, where it cats find in abundance the thomy shrubs of the clesert ranges, which

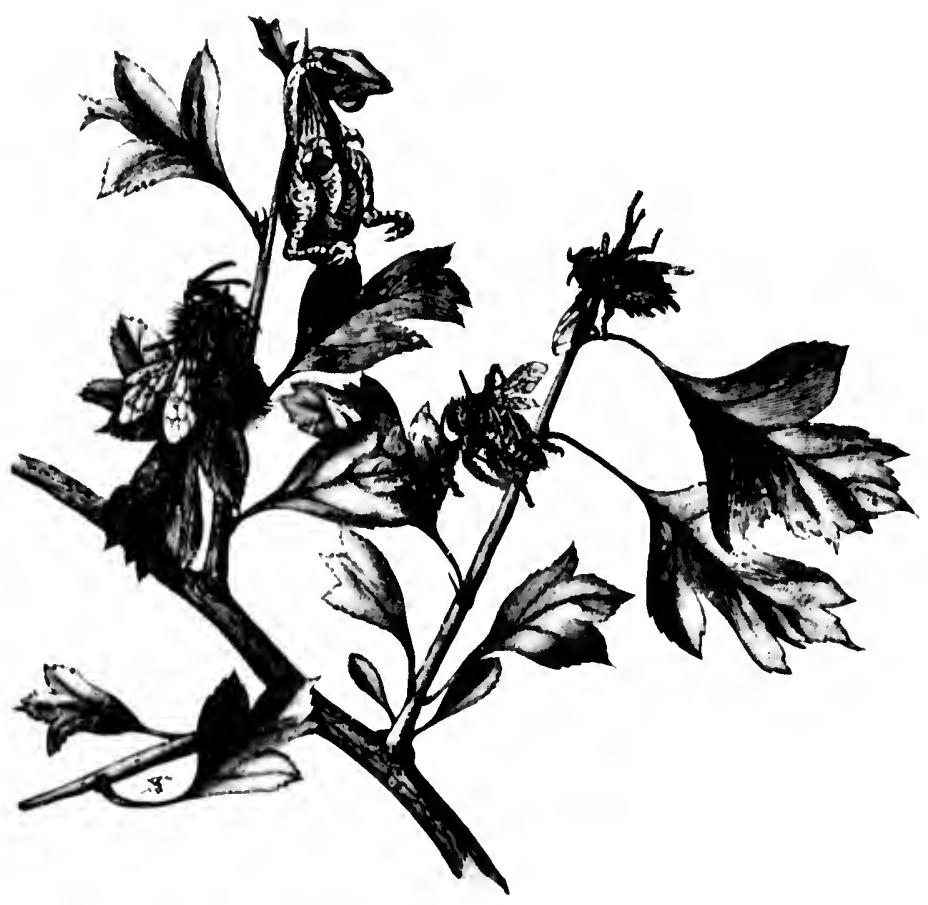

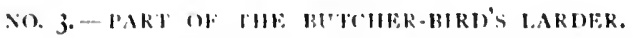

stand it in good stead ats pegs or hooks on which to base its larder. In England, it msmally selects a hawthern for its seene of operations.

No. 3 shows fall better thath I call describe it 
the nature of these food-stores, where the butelerebird lays hy meat for himself, his mate, and his untledged young. The larder is always situated in the neighbombood of the nest, and the male bird hunts for flies, bees, and other insects, while the female sits on the engs hard hy. He cats a few at once, to allay his hunger, spitting them first ats a means of holding them ; but the greater momber he preserves alive mpon the cruel thorms for the use of his mate and his callow nestlings. "Les pires de famille," siad Palleyraud, "sont copables de ton'." And we may well exclaim, "Oh, parental alfection, what crimes are perpetrated in thy name!"

The particular portion of the larder which Mr. Enock has selected for representation contains a bumble-bee, two lange flies, and a nestling heclge-sparrow, stolen from its mother; for the butcher-bird does not wholly confine himself to a diet of insects; he is cammibal emomgh to catch and eat other hirds, not to mention mice and such small mammals. So fierce and salvage is he when on the hunt after prosender, that he will even spear and impale larger hirds than himself, stech as blackbirds and thrushes. Not content with hanging them on the thoms alive, he will fasten down their legs and wings hy an ingenions cross arrangement of twigs and branches, so so to prerent them from escapings ; fir he does not so moleh desire to kill his prey, ats to keepe it alive till he is ready to cat it or to distribute it to his fantyly. He knows that dead birds som decaty; and he 
doesn't like his game high: but he also know's that womnded birds will live on and keep quite fresh for days together; so he is careful to disable without actually killing the creatures he captures.

Among the animals I have seen in butcherbirds' larders I may mention mice, shrews, lizards, robins, fomtits, and sparrows ; among the smaller birds he especially affects willow-wrens and chiffchatfs: hut keepers tell me that they have even fomel them seizing and spitting yomms partridges and pheasants. Whether this is true or not l cannot sily ; but the game-preserving interest certainly looks npon shrikes with no friendly eye, and you may sometimes see one homg up on a mail among the jays and hawks and stoats and weascls on the "kecper's trees," where the shardians of the wood display the eorpses or stans of evil-doers as a terror to their like, much as mediaeval kings displayed the heads of trators above the gattes of the city.

Oddly enough, howerer, these "kceper"s trees" themselies are favourite ham ts and hawking-piteles of the butcher-biad, who is so little deterred by the supposed lesison that he uses them as comvenient places for catching insects. For, in spite of his occasional carnivoroms tastes, your slutice is at heart, and in essence, an inseci-eater. He alds a monse or at tit at an exceptional luxwy. Now, he kmows that the owls and stuats hung up on the keeper's rustic musemu attract numbers of carrion thies, and he therefore perches ealmly on the 
boughs above the mouldering remains of his own slaughtered brother to await the insects that come to devour him.

Then he darts upon them with something of the fly-catcher's cagerness, eating them up at once, or tlying off with them alive to in. pale in his storehouse.

lin No. + we see the female butcher-bird, on he! return from a successful chase after prey of sreater import. ance. She hats camght a hatrestmouse, the tiniest and pretticst of out English mammals, and though without a license to hang game, hats threaded it

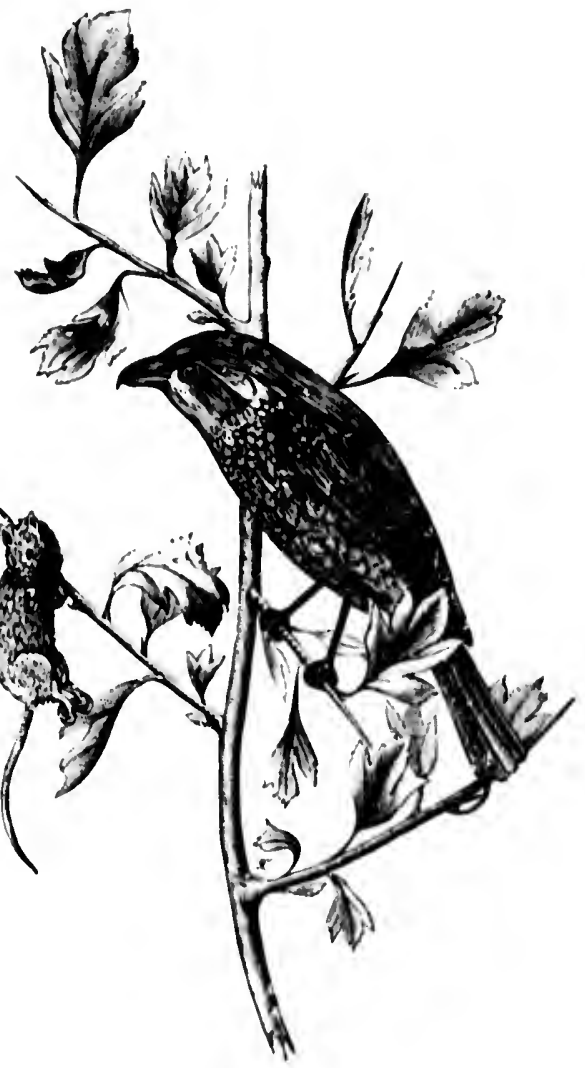

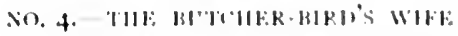

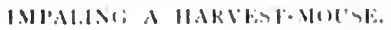

through the neck on a branch of hawthorm, ats a preliminary to eating it. This enables her to 
lobld it comenententy ats on a fork of stewer while she pecks at it. Sometimes yon will lind the mice fastened thromgh the body, and gnawing the twig with their teeth in their prolonged angony. But the buteher-hird takes no notice of their writhings and their groans: she treats them with the indifference of a fishmonger to lobsters. It is lier business to provide for leer own yomug, and she does it ats ruthlessly as if sle were a civilised human being.

'The shrike's ordinary metherd of capturing prey closely resembles that of the tly-cattelere, to which, howerer, it is not really reliteil. The resemblance is merely one of those dese to similarity of labit. Every well-conducted butcher-bird hats a settled pereh or pitch on which lac sits to watch and wait, and to which he returns after each shont excursion. Flies and hees he catclese on the wing, dattings down "1pon them suddenly with a swewp lilie : kinglisher's; but be also often tatkes them sitting, especially when they are settled on a leat or banch, or atre eatting catrion. Onc of his most fatombite hunting-boses is a teleggraph wire, and he prefers one that erosses the corner of a wood ; there he will sit with his head held sapiently on ane side, kecping a sharp look-out from his beady hrown eyes in every direction. If a bee lights onl a head of closer, if a cockehater stirs, if at mouse moses in the gratss, if a fleclgeling thrush makes a first unguarded attempt to ty-woe beticle the poot innocent ; our hutcher-hirel is upon him, with a fierce darting heat, and in ten seconds more, his 
whithing bexly ackls to the store in the shrike's latrore.

A sumed plater and time to watteh a buteher-bird at work is in a quied field he a copse just after the mowings. But gou must hide catrefully. The short eratsis is then full of hectles, erickets, and gratsslopplers, ats well at of mice, shrews, and lizards, who can enoceal themseleces less eatsily than they were wont to do in the long hay hefore the cutting. At stech tinnes, hawki and owh matice a tine liveli-

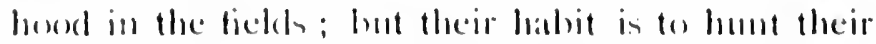
youry on the opens. They hoser and drop upon it. That is mot the butchep-bird's platu; he is a more cautions and secret fore ; he sits castally on his hralleh or his telegraph wire, with his head ont one sicle, till his prey stars vishly ; then he ponnees

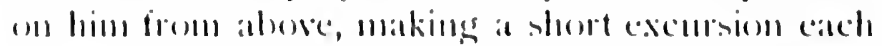
fimse, and returming to rest an his aceustomed postions. When lie catches a hird, and cats it at once, he hesime hy -prtting it an at thom: then be attacks the skull first, breaking it theough and

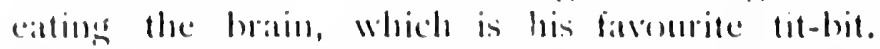
Ile alon makes mach on the nesto of other birels, and carries off the nestlings.

If you open the crope of a butcher-hird, the contells will show youl that, in Eustand at least, its matal anticles of diet eomist of bees and flies, but enpecially of heetles. It in full af the ir hatel wingscances. №w, ormitholongists hate longs noticed that the distribution of buteler-hides in the land is rery caprecions ; in one district they will be fairly numerous (though, at hest, they are rate hirel-), 
and in another, elose by, they will be very uncommon or quite anknown. It is probable that this relative frequency or scarcity depends upon the distrilution of their proper food-insects. Indeed, just as we all know that an "army fights "1pon its stomach," so we are beginning to know mow that commissariat lies at the bottom of most problems of animal life. 1 used to wonder on the Rivicrat why trap)-cloor spiders, with their long tubular nesti, were abundant in eertain deep red clay-hanks, hut wholly wanting in others, just as summy, just as soft, just as easy to tumnel ; till one day it struck me that the spiclerless hanks were expesed now and then to the cold wins, the mistral, and lence were naturally almost tlyless. As a matter of ecourse, the spiders went where the flies were to be found ; and these open banks, though sumny and warm, were from the spider's point of view mere klondykes or Sahatrats.

It is just the saune with the butcher-birch. Beefles and bees frequent for the most part warm, erumbling soils; they are infrequent on damp clays and chilly, marshy places. Sandstome and chalk attract them; on Iondon clay or the damp thats of the lleald they are few and far between. Hence, where the heetles are, there will the shrikes be gathered together, They abound (comparatively) in watrm sindstone hills, lut are almost mokmown in chilly clay districts. Not that they mind the eolla ats such; it is the question of food that really affects them. So, too, with the swallows and other long-winged insect-hawkers. 
The swift flies very high, and lives on summer insects, which come out in July and August only ; so lae arrives here late, and goes away again sometimes ats early ats the date of grouse-shootings. The house-matin, on the other hand, subsists on lowtlying midges which surround homses; he therefore comes tirst of all his group, and goes awaty latest. The night-jar flits over fern-clad or heather-clat moors, and feeds almost entirely on certain nighttlying beetles and moths; hence he atrives when they hatch out from the cocoon, and flaps southward again on his big, overlapping wings as soon ats they have disappeared or heen mostly eaten. It is all a question of commissariat. Our carly English kings had manors of their own in many parts of the eountry, in all of which supplies were laid up thromghout the year for the royal table; in due tince, the king arrived with all his comt, stoppeel a month or six weets, atte up all that wats provided for him, and then rode on with his humgry horde to the next royal manor. It is just the same with the bircls; they come and go ats supplies are assured them. The slurike stops in England while bees and beetles last; when prorencler fails, he is off on his own strong wings to Rhodesial.

No. 5 introduces us to another strange secence in the eternal epic of prey and slatushter, It shows us how beetle proposes, but shrike disposes. Here, parental feeling mats against parental feeling. A busy group of burying-bectles have lighted upon a dead field-mouse - itself hawked at, perhaps, 
and womnded by "a mousing owl," but not quite killed at the time, and now abandoned on the open. The hurying-hectles, all agog, proceed to cover it with a layer of earth-not, indeed, ont of such instinctive piety as that which induced

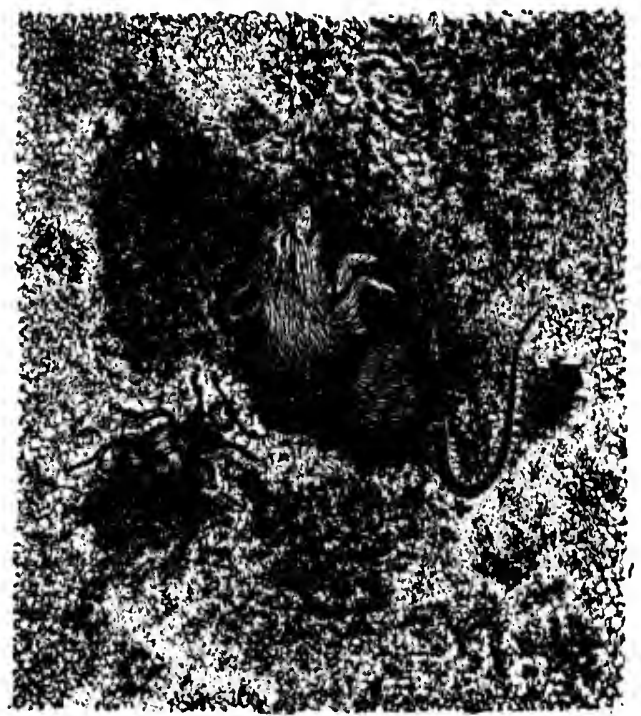

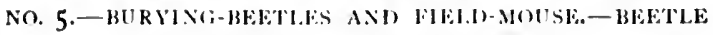
DROPOSLS, BUT SHRIKE IDSIOSLS.

the robin-redbreast and the wren in the story to cover the Babes in the Wood with mouldering leaves, but for a much more prosaic and practicai, though none the less praiseworthy, motive. They want to lay their eggs in it, so that the maggots may have. plenty to eat when they hatch out-for 
these burying-beetles are carrion-feeders, whose larve thrive on dead and decaying animals; and they desire to bury the corpse in order to keep it intact for their own brood, without interference on the part of other and more powerful carrioneaters. When successful, they cover the mouse entirely with mould, and thus leave their young supplied with a liberal diet.

But hidden among the greenery of a tree overhead, a cynical butcher-bird is calmly watching those insect sextons from the corner of his eye. As soon as enough of them have collected on the spot, he will swoop down upon their bodies unseen from above, and will carry them off to spike them on his own pet thorns for the benefit of his struggling young family. Thus does parental affection war unconsciously against parental affection. Each kind fights only for its own hand, and regards only the young of its own species. For as Temnyson says well in "Maud" :-

"Nature is one with rapine, a harm no preacher can heal;

The Mayfly is torn by the swallow, the sparrow speared by the shrike,

And the whole little wood where I sit is a world of plunder and prey."

No. 6 shows us one memher of the butcherbird's young family, just hatched and fledged, in his streaky grey plumage, and begimning to go out upon the world for himself. He is trying to catch an insect on a thorn above him. It also suggests to us the appropriate moral that if 
you train up a butcher-bird in the way he should go, when he is old he will not depart from it. Lessons of cruelty are here imbibed-I cannot

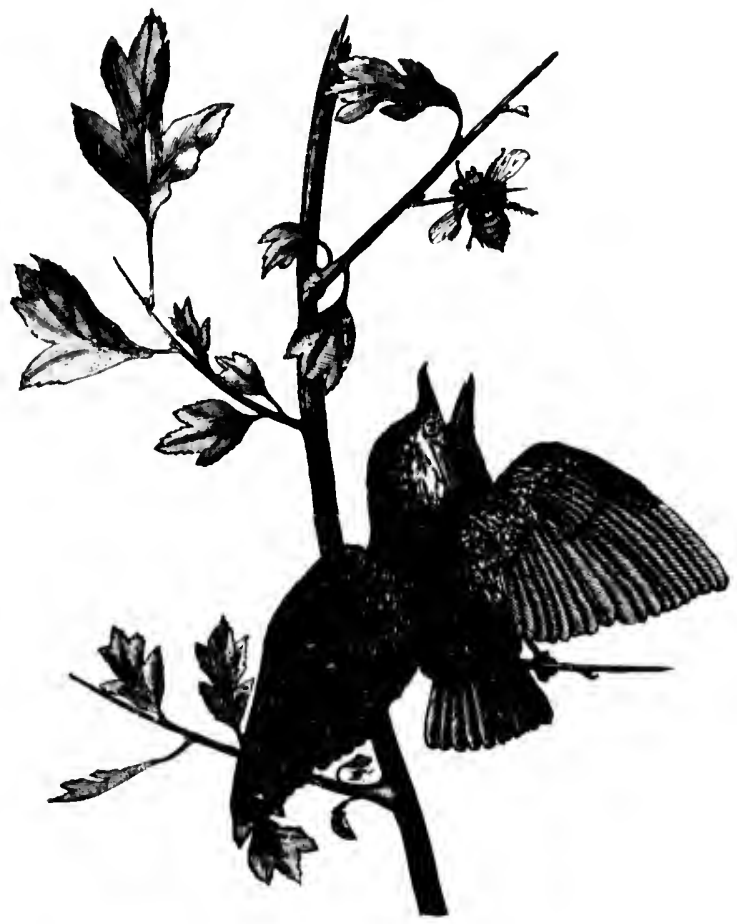

No. 6. -THE NAUGHTY BUTCHER-RIRD-" "I WANT TIAT FIY !"

truthfully say, "with his mother's milk," but at least from his father's and mother's example. While the mother-bird sits upon her nest (as you see her in No. 7), the little chicks are fed 
"by hand," so to speak, with captured insects. But as soon as they can fly a little, they come out and perch upon the twigs of the larder, that

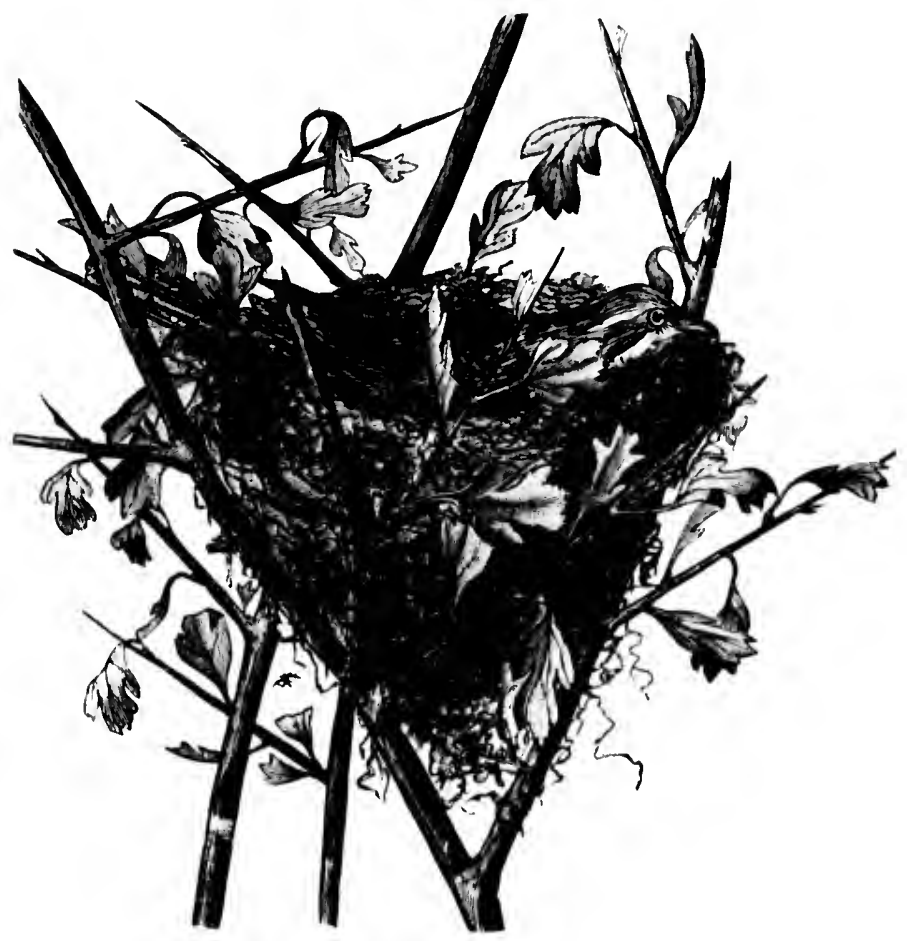

NO. 7.-THE BUTCHER-BIRIS WHFE SITTINi ON HER NEST.

they may learn fly-catching hy helping themselves to insects spitted on the thorns, where parental affection, however misguided, has placed them for that purpose. Thus they imbibe a taste for 
living food from their earhest moments. As Prior long ago put it :-

"Was ever Tartal fierce and cruel

Upon the strength of water-gruel?

litt how restrain his rage and force

When first he kills, then eats, his horse?"

What the butcher-bird requires in his place of residence, then, is, ahore all things, easy access to warm sandstone or limestone tracts, with plenty of insects, lizards, mice, and small birds; he also needs an open common to hunt over, hushes and trees on which to perch at watch, and clumps of thorn-bearing shrubs to provide him with a larder. There he builds his rude nest, one of the roughest and most inartistic I know; and there the mother brings up her young in her own wicked fashion. But though a rather shy bird, the shrike does not wholly fear or shun civilisation; for the rich insect population of our garden often attracts the wicked pair ; and in July and August, when flies are rife among the fruit-trees, they will bring their young brood into the curiant and gooseherry beds, and teach the young iciea how to shoot in the manner proper to so carnivorous a species.

As a matter of evolution, the shrike's position is a very interesting one. For he is not exactly a bird of prey-certainly he does not helong to the hawk and eagle order. His near relations are all mere insect-eating birds; but he has gone a little beyond them in his carnivorous habits, by adding mice, birds, and lizatrds to his diet. His 
great discovery, however, is his cruel device of using thorns for his larder; this ingenious but hateful invention it is which has secured him a place in the struggle for existence. It is curious to note, too, how the habit has reacted on the bird's structure and appearance. He has acquired the quick eye and nervous alertness of a hird of prey, and has even grown like that higher group to some small extent in his beak and talons. He is a wonderfully plucky little fighter, too, both against his own kind and against other species.

Have you ever reflected how wonderfully varied and eventful is the life of such a migratory bird as this cruel butcher? We human beings, who can only travel south in one of the crawling expresses misnamed trains-de-luxe, have little conception of the freedom and variety which every mere shrike can claim as its birthright. Let us follow one out briefly through its marvellous lifecycle.

It is hatched from a creamy-coloured and dappled egg in a nest in England. From four to six brothers or sisters occupy the home, and, indeed, to be strictly accurate, more than fill it. Everyhody knows the old conundrum, "Why do birds in their little nests agree?" with its quaintly sensible answer, "Because, if they didn't, they would fall out." Well, with the butcher-birds, that remark is literally accurate. The nest is a ragsed and rickety structure, hardly big enough to hold the young as soon as they are fledged. It is built in the boughs of a thorn bush, and 
near it stands the well-stocked parental larder. The young butcher-bird, as soon as he can fly, is taught to eat insects from the family hoard, and later on to pick them up for himself on the wing in the open. $\mathrm{He}$ is usually hatched about the beginning of June; by the middle of July, his mamma and papa take him on the insect hunt into neighhouring gardens. In his early plumage, he takes after his mamma, but already shows some signs of the white tips and black markings which will distinguish him as a male bird in his aduit existence.

Once abroad in the world, he grows apace; and this is necessary, because, about September, he will have to fly off with his affectionate parents on a long, forced journey to warmer winter quarters. Not, of course, that he minds the winter in itself; but the flies and beetles are gone; their sole representatives are now the eggs and chrysalids; mice and lizards have retired into winter quarters ; no small birds are about in the unfledged condition where one gets a fair chance with them; and altogether there is nothing for it but to travel south and find more plentiful support in some warmer country.

Se southward the family flits, when partridge shooting begins, first over Channel to France, and then on to the Mediterrancan. But food is scarce even in Provence and Italy during the winter months; so our wise young shrike and his parents do not loiter ahout with the invalids and flancurs at Cannes or Naples; they strike right across sea, 
via Sicily and 'Tunis, to the Nile Valley. Thence, anticipating $\mathrm{Mr}$. Cecil Rhodes and disregardful of railways, they keep straight on, with glorions views of sea and mountain, past the Mahdi's land, till they arrive at the great lakes and British South Africa. At least, that is the course pursued by the greater number, though a few more original families (mostly Russian by birth) trend eastward towards the Persian Gulf, and winter, after the now fashionable manner, in Inclia.

During his absence in the south, our shrike grows adult, and also puts on his fine spring colours (which are his courtship suit, intended to charm his prospective mate), just before his return in May to England, or rather to Europe; for of course I do not mean to say that he necessarily comes back to his native country ; though there is reason to believe that most migratory birds do really return year after year to the same quarters. They have a summer residence, so to speak, in France or England, and a winter one by the banks of the Zambesi or the Indus. Most butcher-birds that visit Europe in the spring come fairly far north, nesting in Northern France, Sonthern England, Belgium, Holland, or Germany. Few nest on the Mediterranean, probably because the summer droughts in that arid tract are unfavourable to their food-insects ; those that remain in Sonthern Europe or Western Asia choose, as a rule, the cooler and moister mountain regions, such as the Balkans, the Greek hills, Armenia, and the Cancasus. The English residents fly back from their African 
home (where they now enjoy the blessings of British rule quite as fully as in Britain) well fattened on juicy southern insects, clressed in their courting dress, and ready for the serious business of settling in life, choosing a mate, and rearing a young family. Indeed, observers in Eastern Africa have noted them during the intermediate period, sitting on the thorny shrubs, such as the Egyptian acacia, which abound in that region, and already adorned in their brilliant breeding plumage in anticipation of their return to their northern quarters. Some people say that the shrike even makes two nests a year (as the swallow certainly does), one in the north and one in Africa; but this is unlikely, and Dr. Sharpe, of the British Museum, will have nothing to say to it.

It is at the mating seatson especially that you have a chance, if ever, of catching sight of the butcherbird himself, seated, all eagerness, on his look-out tower; and enjoying life with the calm begotten of that fine old recipe--a bad heart and a good digestion. He sits and utters his amatory feelings now and again in an abrupt little "chuck, chuck," which is whipped out surldenly, with a jerk of the head sideways as an appropriate accompaniment. About the same time, too-say the beginning of June-you stand the best chance of coming upon one of the larders, all stocked with fresh meat ; for later in the year, when the young are well fledged, the shrike gives up its murcierons practices a little, and takes its young on the prowl for themselves in orchards and gardens, in order to accustom them 


\section{A Woodland Tragedy}

to the habit of catching prey. But I suspect my evil friend of often murdering for mere murder's sake, as generally happens with predatory animals ; they acquire a certain love for the chase as such, and even seem, as one may observe in cats, to delight in cruelty for the sensuous pleasure of inflicting pain on others. Your shrike has no inkling of a conscience. He does wrong boldly, with sublime indifference; and believes himself to the end to be a model father, a tender husband, an ornament to society, and a useful cition. 


\section{V \\ MARRIAGE AMONG THE CIOOVERS}

DIANTS marry and give in marriage just as truly ats animals. They have their loves and their hatreds, their friendships and their enmities. The marriage customs of many among them are valstly interesting; and yet, in spite of all the attention that has been given to the subject of recent years, comparatively few people are even now aware how quatintly they pair, how varied and curious are their matrimonial arrangements. Most of us, it is true, have heard by this time the bare facts of the case-that flowers are mainly fertilised by the visits of insects: many of us even know that in the majority of instances the little golden dust which we call pollen must be transferred from the hanging bags on one blossom to the sensitive surface of another, or else seed will never be set; but not all of us are aware how intricate and how numerous are the minor devices by which each kind of plant effects this important object in its own fashion. I am going, therefore, in the present paper to describe briefly the marriage customs of two alone among our commonest clovers, which I shall adduce as specimens of the strange 
variety to be found within the limits of a single type.

To hegin with, however, I propose to examine, as a mere introduction, a comple of flowers of a well-known and dainty hot-house hegonia, which may help us to the comprehension of the more plebeian clover-heads. I'roverbial philosophy hats long since taught us that "the longest way round is the shortest way home" ; and when I drang in the begonia, which has apparently so little connection with clover, and which is really about as unrelated to it hy descent as two tlowering plants can well be to one another, you may suspect that I do so for sonic sufficient reason. The fact is, begonias happen to be plants in which the differences of the sexes atre exceptionally well marked, so that they may be apprehended with ease by the naked eye and by every obscrer, even the most casual. I advise those who have conservatories of their own to verify my statements in this matter on the specimens in their possession; for those who have not, Mr. Enock's excellent illustrations, which accompany this paper, will serve almost as well as the original objects.

Most cultivated begonias have the flowers on their branches arranged in groups or clusters of three, the central one of which is often a female, while the two outer blossoms are usually males. This is the ordinary plan, but it does not hold good of all the species, some of which, on the contrary, have only one male to each pair of females. Now, these male and female flowers are so very unlike in 
form and structure, when you come to look into them, that you would hardly believe they belonged to the same plant if you did not find them growing on one branch together. They differ quite as

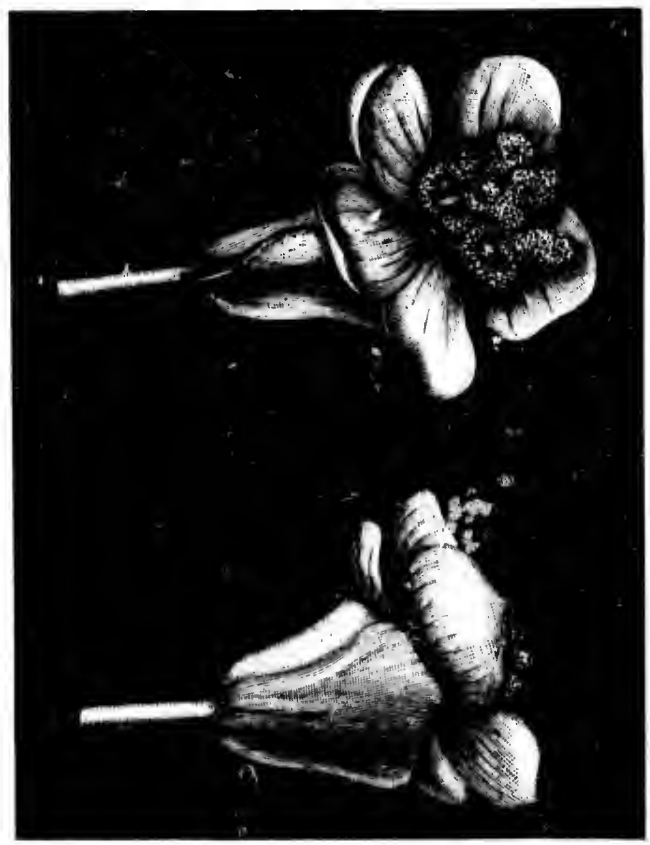

No. 1.- FEMALE BlgoviA Flowiks, FRONT ANH BACK VHEW, SHOWING; THE SLED-BAT:

markedly as the peacock differs from the pea-hen, much more markedly than man differs from woman. A glance at No. I, and then at No. 4, will make this point obvious. You would say, if shown them 
separately, that these two blossoms must surely be flowers of quite distinct species ; yet they hang side by side on one and the same plant like brothers and sisters.

The first point of difference which you will note in the two is that the female hegonia, as seen in No. I, has five petals, while the male, in Nos. 4 and 5 , has four only. (I call them petals both for brevity's sake and because I believe them to be so in reality, though fear of that terrible critic, Dr. Smelfungus, who goes about like a roaring lion seeking whom he may devour, compels me to add that in the learned Doctor's opinion they are parts of the calyx - a petty distinction with which, but for him, l would not have troubled you.) But what is far more important than the number of the petals is the fact that the female flower has wedged at its hack a large triangular-winged ovary, or seed-capsule. It is the possession of this ovary, indeed, that marks it out at once as a female: for by a female plant or animal we mean, of course, the one which lays the eggs, produces the seeds, or becomes the mother of the young individuals. If you compare the hack of the female flower in the lower portion of $\mathrm{No}$. I with the back of the male flower in $\mathrm{No} 5$, you will recognise at once the importance of this distinction. The female blossom has a seed-hag, while the male is barren. ln No. 2 we have represented one such seed-bay cut open crosswise, so as to show both the projecting wings and the numerons little seeds in the three cells within. 
But this is not all: the other parts of the two flowers differ almost equally. The eentre of the female blossom is oceupied, you will ohserve, by several twisted and wriggling arms, the upper surface of which is more or less sticky. This surface forms the receptive portion, or mouth of the flower, on which grains of pollen must be duly deposited before the embryo seeds in the cap-

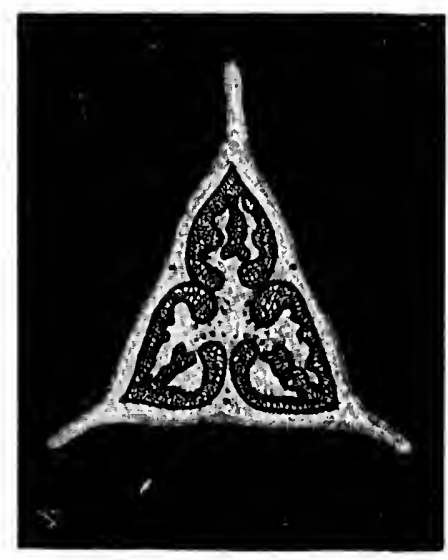

NO. 2. -THE SEEH-BAG, CUT AcRnss. sule helow can begin to swell and develop. On the other liand, the ecentre of the male flower, as seen in No. t, is occupied by a set of very different organs, the stancus or pollen-bags, whose business it is to produce and shed the fertilising powder. Without pollen to start them, the seeds are useless. In the wild state, any winged insect which visits the plant is likely to alight first on the lip or platform of one or other of the outer male flowers. In his search for honey, which is secreted by the plant at the hase of the petals on purpose to allure him, the flying visitor dusts himself over abundantly, though unconsciously, with grains of pollen from the very numerous little sacs which are placed there in a convenicut situation with that 
precise object. He then flies away to the female flower, in which he alights, as a rule, on the central sticky portion (called by botanists the stigma): and as he walks over it in search of the honey at the base of each petal, he turns himself round and round in five directions, and thus muittingly rubs off the pollen which clings to his legs and hairs, transferring it to the sticky and receptive surface. After visiting and fertilising the female flower in the centre in this manner, he then usually proceeds to visit the second brother beside it, from which he carries away pollen in turn to the nexit

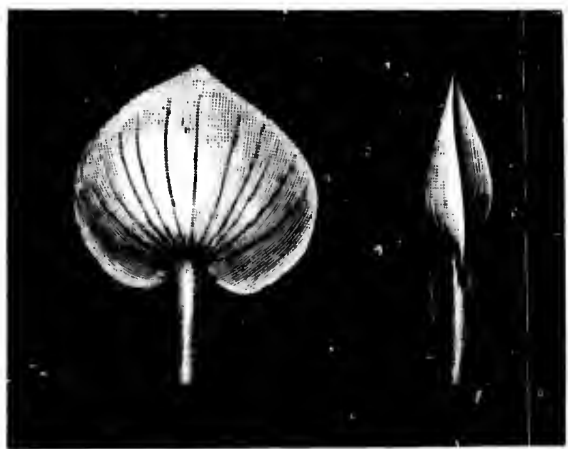

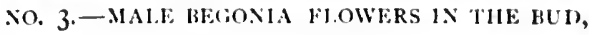
WITH NO SEEI)-BAG. plant he visits.

The object of this curiotis arrangement is that each flower may be fertilised by pollen from another blossom, and, as far as possible, in many instances at least, hy pollen from a clistinct neighbouring plant. But you will gather at once from what I have said already that each plant must be regarded in strictness not as an inclividual, but rather as a community or commonwealth, of which the leaves and flowers are the separate members told off to perform different cluties. You nay 
compare it, indeed, to a hive of hees, the leaves representing the workers, while the five-petalled flowers are analogons to the queen-bees, and the four-petalled blossoms to the hushands or drones.

Nay, more: those of

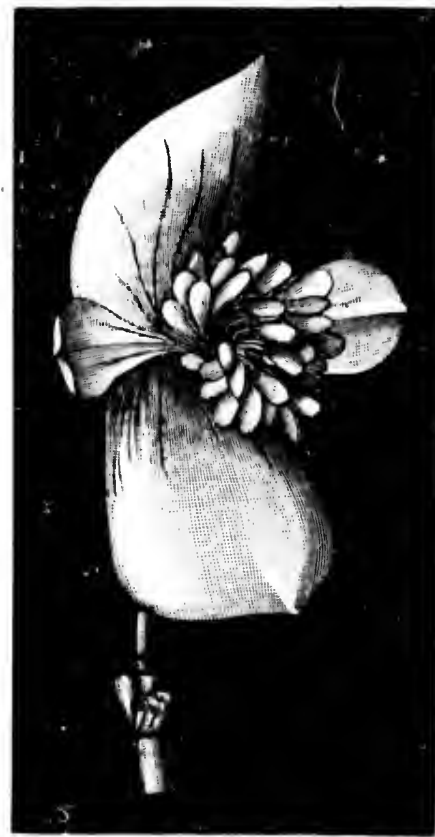

NO. 4 -MAIE BEGONIA HIOWER, FRONT VILW. my reaclers who have hegonia plants of their own may observe for themselves another singular resemblance to the habits and manners of honey-bees. For after the drones have done their work in life by fertilising the yueenbee, the prudent workers sting them to death, as being neless mouths, of no further benefit to the community; but the queen-bee necessarily survives to become the mother of young swarms, or future generations. If she were killed, it would he all up with the community.

Just so with the hegonias; as soon as the male Howers have performed their whole duty in life, by producing and disseminating the grains of pollen which the insects earry away and smear upon the sister hlossoms, they break off at the 
joint shown in the illustrations, and fall to the ground ; the plant refuses to feed them any longer, because it has now no use for them: but the fertilised female flowers remain fixed on their stems to produce the seeds, from which will spring in time the future generations.

What, howerer, do I mean by fertilisiation? Well, each pollengrain, when closely examined uncler a microscope, looks like a tiny egg, with a very thin shell and very sticky, active contents. As soon as the pollen-grains are rubbed all over the curly branches in the centre of the female flower, they empty their contents down long tubes, which reach at last to the seeds; and under this

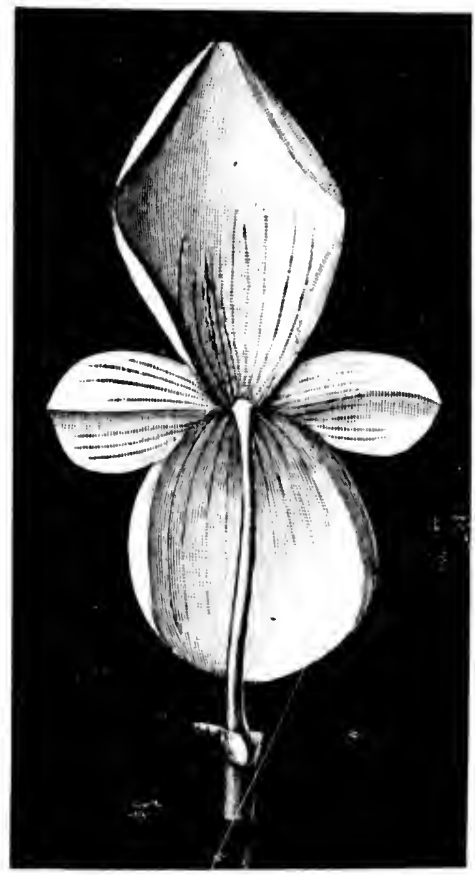

NO. 5. MAL1: BECOONA Fl.OWER, औACК VIEW. rivifying influence, the seeds begin to swell and beconse capable of producing young plants. The pollen, in short, hats quickening power. It is for the sake of this final result alone that the flowers exist: they are pro- 
vided with bright-coloured petals as advertisements to let the insects know where honey may be expected; they secrete the sweet liquid itself in order to induce their winged allies to become common carriers of pollen for the benefit of the begonia; and as soon as each flower has served its purpose in this respect, it clrops off or is retained by the plant according as it is or is not wanted in future for its seed-producing properties.

The difference between the brother and sister flowers is even more visible in the bud than in the fully opened blossom. No. 3 show's us this very well in the case of an unopened male blossom. Here the two large petals, afterwards used as platforms for the insect to alight upon, enclose the smaller pair of interior ones, as well as the bunch of yellow stamens. But as these stamens are full of nutriment, and therefore liable to be prematurely attacked by useless gnawing insects, the petal above them is thickened in this part, and in one of the species most cultivated in our greenhouses, but not figured here, is provided with little protective hairs, which baffle and keep at bay all hungry aggressors. I may add that the projecting wings on the seed-ressel, well seen in No. I, and also in the section in No. 2, serve a somewhat similar purpose: they are intended to prevent hostile insects from laying their eggs at the most vulnerable points in the capsule, where the grubs would destroy the seeds within. The thickenings above and helow, also to be observed in the lower figure of No. I, perform a like service. They 
are devices of the mother to protect her young. You will thus perceive that the begonia has its friends and its enemies in the insect world, and that while it does its best to conciliate the one, it is no less anxious to repel the other. We shall find in the sequel that precisely the same thing is true of the clovers.

To the clovers then, which are our proper subject, I will next proceed. And I began with the hegonia by way of introduction, only hecause that afforded us a case in which the husbands and wives of the community were so distinct from one another that nobody with a pair of eyes in his head could fail to distinguish them when they were once pointed out to him. In the clovers, on the other hand, we have a much more complicated arrangement, and one much less like the ordinary cases with which we are familiar in the animal world. Here, the flowers are collected in leads or clusters, and each flower is in itself at once hoth male and female. This method, indeed, is common amongst plants; it occurs in hy far the greater number of species: the reason why I started with the begonia is just because in that type the sexes are so well and clearly separated in distinct blossoms. In the clovers, however, each separate flower resembles a small pea-blossom in shape, having four petals, which botanists name respectirely, frem below upwards, the keel, the two wings, and the standard. These petals are best seen in the single lupstanding flower (or "old maid") represented in No. 9. They are enclosed beneath in a small 
greenish calyx or cup, and they contain within them ten stamens or pollen-bags, as weil as a tiny capsule like a miniature peatpod. At the tip of this capsule is a small hook-the sensitive surface on which the pollen has to be deposited. You would say at first sight that under such circumstances, male and females being mixed up in one, crossfertilisation must be impossible - that each flower must surely be fertilised by its own pollen. But the clever clovers have invented an ingenions little device of their own for overeoming this difficulty : the pollen-bass and the sensitive surface of the capsule do not arrive at maturity tosether. In this way each flower or plant gets fertilised itself at one time by pollen from another plant, and at another time clusts the bee that visits it with its own pollen, which the bee transfers in clue course to the next plant it visits.

No. 6 represents part of a plant of Dutch clover - the common white clover of our meadows and pastures. It is called Duteh, not I believe because it is particularly common in Holland more than in other European comntries, but becalse the prudent Dutch were the first agriculturists to collect and export the seed of this particular closer separated from all other seeds of similar hut less useful species. It happens to he a particularly good fodcler plant, and it srew wild originally throughout the whole of Europe and temperate Asia, from the Mediterrancan to the north of Norway. But

1 I hope technical botanists will forgive me some slight but unimportant simplifications in this not entirely accurate mode of presentation. 
the seed has now heen sown for pasture in almost every comutry of the civilised world, so that wherever this rolume circulates, its reaclers can find and observe the plant for themselves, "to witness

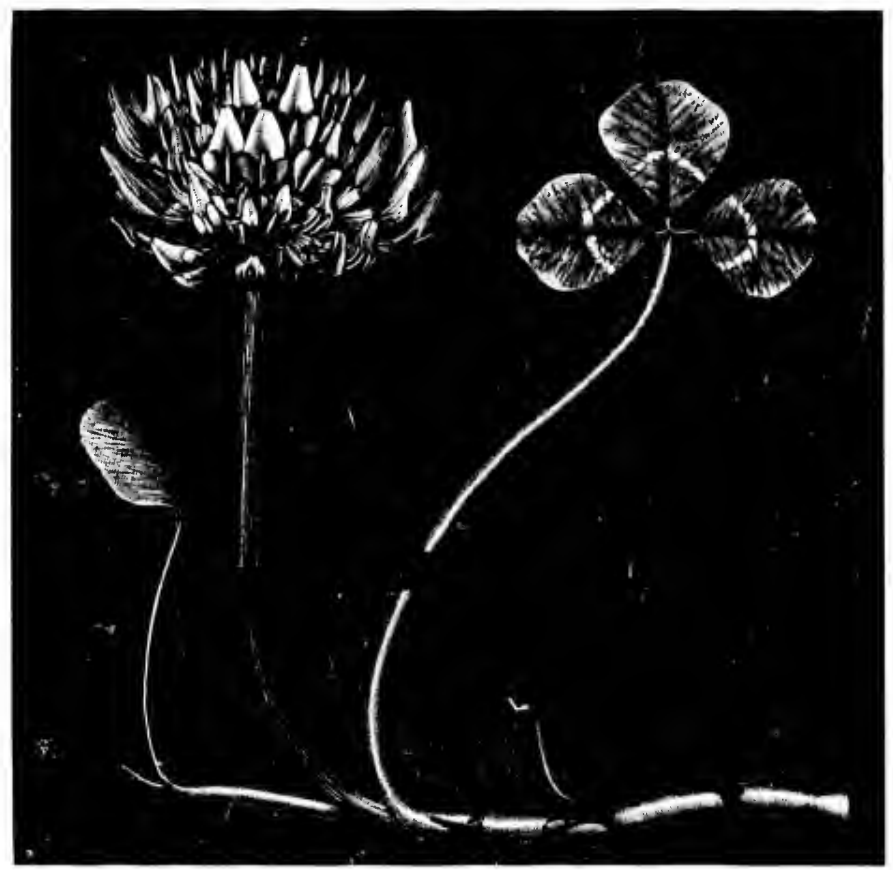

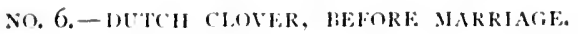

if I lie," as Macaulay's Roman poet hluntly puts it. Dutch clover is a rather smooth specimen of its type, not nearly so hairy or silky as most other clovers, for a reason which I will explain a little later on: it has prostrate stems which creep alongs 
the gromud, as shown in the illustration, and root every now and again as they proceed, somewhat after the same fashion as strawbery-runners. Like all other clovers, it has trefoil leaves, each of the three leaflets in which is usually marked with a curved spot in the centre resembling a horse-shoe. But it is the flower-heads with which I am here particularly concerned. These are raised on long, erect, leafless stems, each of which bears on its summit a globular head of little white pea-flowers, often delicately tinged with pink or salmon. The flowers are thus lifted to a considerable height, because this clover grows, ats a rule, among rather tall grasses, and so tries to push up its blossoms to a height where they may receive the polite attentions of patsing insects.

The visitors for which Dutch clover specially lays itself out are for the most part bees. It disdains small pilferers. Each blossom has a long tube enclosing its honey, and only insects with a correspondingly long proboscis can reach its deep store of delicious nectar. It thus saves itself from being rifled uselessly by small insect riff-raff, such as flies and midges, which might visit the flower, as we botanists call it, "illegitimately"-that is to say, might rob the honey without conveying the pollen from the pollen-bags of one head to the sensitive surface or stigma of the next. The parts of the thower, in fact, are specially arranged with a definite relation to the head and the honey-sucking tube of hive bees and wild bees, which cannot visit it without dusting themselves over with pollen 
on one blossom which they unconsciously rub off on the receptive surface of the next. In one word, Dutch clover encourages hees for its own purposes, because they are useful to it, while it places obstacles in the way of smaller and useless insects, hy burying its honey in a ceep tube.

The heal of Dutch clover shown in No. 6 is one which has been caught just at the very first moment of flowering. The florets or hlossoms which make up the head begsin opming from without and helow, inward and upward. Thus in this head the outer and lower florets have opened, while the inner and upper ones are still in the bud. When a bee visits stuch a heat of clover, he comes to it first from another head of the same kind ; for bees do not usually mix their liquors; on one round of visits they confine themselves, as a rule, to a single species of flower only, and they probably store the honey of each kind in separate cells, just as we ourselves in our wine-cellars keep one hin for champagne, another for claret, and a third for Burgundy. The hee thus hegins with the outer flower of the head, which he fertilises with pal an from the last plant he visited; he then goes on to the second row, where he dusts himself over with pollen for another flower-head ; and the buds in the centre he leaves severely mmoticed.

As soon as he flies away, a very curions thing begins to happen. The flowers which he has unconsciously fertilised close over their seed-ressel, and grow gradually brown or withered. At the same time, as you see in No. 7, they turn down 
out of the way of the bees by bending the separate little stalks on which they are raised in the head, and tucking themselves tight against the common flower stem. This they

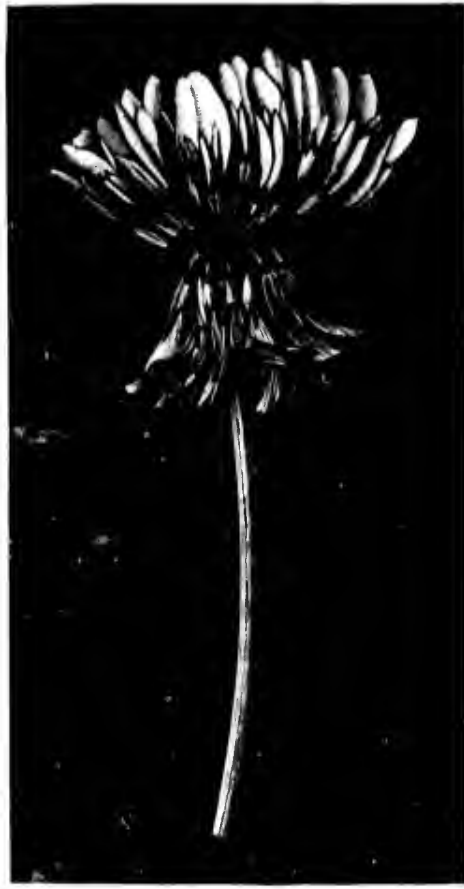

No. 7.-DUTCH CLOVER, THE FERTILISEI FI.OWERS TURNED DOW: THE ['NJERTILISEJ) (OCRTIN) TIL: BEES. do partly in order not to confuse and worry their allies the bees, but partly also to avoid certain other dangers to which I will recur later. Plants often try in such ways to save bees or butterflies time and trouble, because the easier they make matters for the bee or butterfly, the more likely is he to visit and fertilise them. $\mathrm{He}$ is a useful customer whom they desire to conciliate. If a bee on his rounds finds that any particular species of plant gives him annecessary trouble in getting at the honey, he is apt to neglect it and pass it by, in order to devote himself to other kinds which he sees are more business-like and obliging. The moment he comes to a head of Dutch clover, then 
he knows at once that he may safely ignore the dry brown flowers tucied awaty andinst the stem, because they are already fertilised and honeyless; he therefore directs all his attention to the mature and open flowers which are now producing honey and ready for fertilisation. These form practically, as you will see, at each moment the outer row of the flowerhead, and are the ones which naturally first engage his notice as he alights on the cluster.

No. 8 show's us the sime head in a little later stage of advancement. Here, almost all the flowers have now been fertilised, and they are therefore turning their brow'n and faded florets downward against the stem. Two among them, which the bee has only just left, are canght in the very act of bending

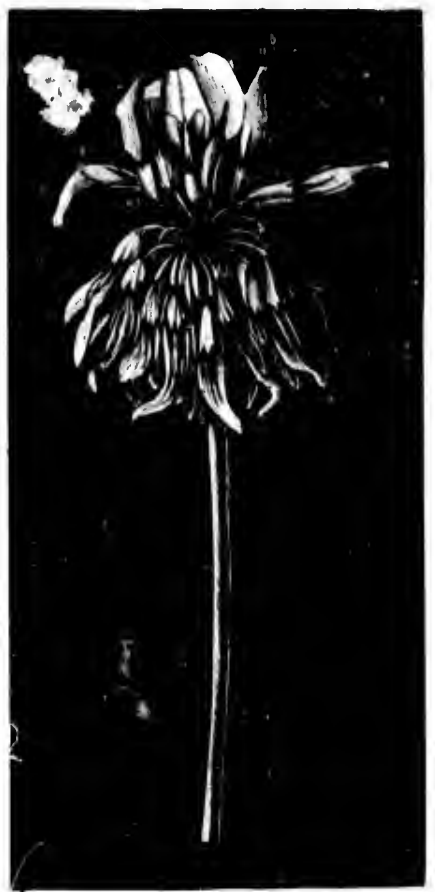

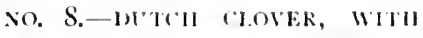
Al.MOST AL, THE HIOWl:kS

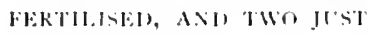

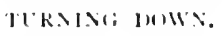
down, so as to get out of the way of any further visitor. The flowers in the centre, which are still erect, were not yet opened when the last bee paid 
a' passing call on the community. They have unfolded their petals since, and are now standing up awaiting their turn to be visited by their winged ally, relieved of their honey, and duly fertilised. It sometimes takes

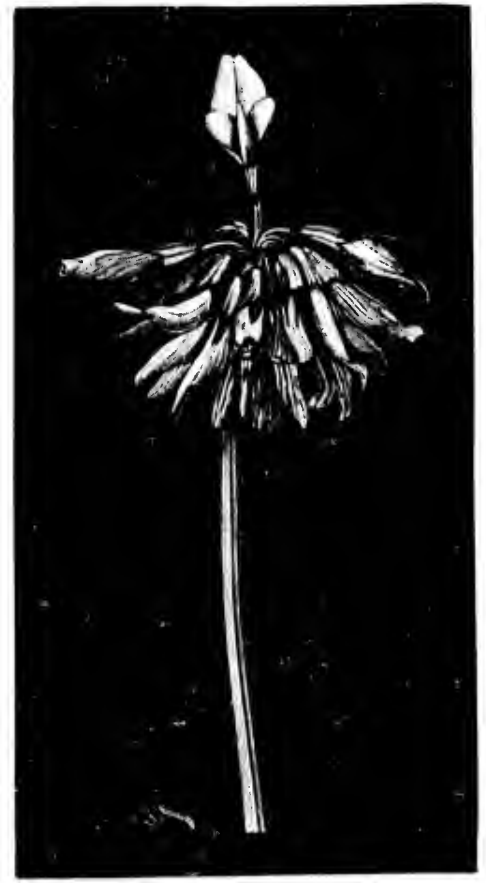

No. 9.-Dutcu ciovek, A sol.tTAR OLI) MAII). four or five days for a single head to pass through all its stages.

In No. 9 we have a truly pathetic picture of a solitary old maid, perked up desolate and alone in the midst of her happier sisters. She was an nopened bud when some passing honey-gatherer visited and set the seeds of her more fortunate relations. The flower on her left, to be sure, has only just turned; it was the last to receive attention from its winged allies. If you search a field of Dutch clover, you will find every here and there such a solitary old maid. But you must bear in mind that none of this is true of the common purple clover, nor yet of the brilliant crimson kind (known to our farmers as "carna- 
tion trifolium "), both of which are distinct species with totally different marriage customs. The insenions habit of turning the fertilised flowers downward out of the way of the insects is confined to a few species of white, pink, and yellow clovers. It is a little dodge on which they happen to have hit, but which has never occurred to their larger and more conspicuous red and purple cousins. So if you try to follow out these hints in nature, you must be careful to hunt for white kinds only.

No. I o shows us the last stange in the lifehistory of a head of Dutch clover. All the flowers have by this time been fertilised; and each flower alike is now pressed down against the stem in a crumpled, brown, and withered-

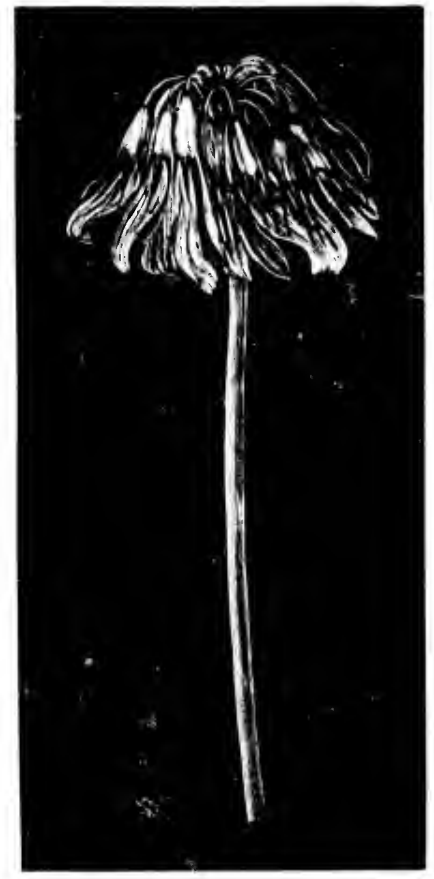

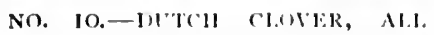

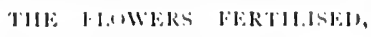

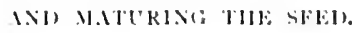
looking mass. The mere casual observer would say, "This clover is dead." But it is nothing of the kind: it is only shamming. The main object of the flowering and fertilisation, 
after all, is the production of seed ; just as among birds the main object of pairing and nesting is the laying of engs and the hatching of their little ones. And this introduces us to a second consideration of great importance. Plants take care of their young. The seeds of clover are small, but they are rich in foodstuffs laid by for the use of the little plant at its start in life. Now, the parent flower is well aware that many insects love to lay their eggs and hatch out their grubs in pods of this character; if you have ever shelled peas, you must have seen such grubs very frequently in the pea-pods. The maternal instinct of the mother makes her lay her eggs where food is abundant; the maternal instinct of the mother-plant makes it do its best to protect its young against such devouring enemies.

In No. I I we see a flower of Dutch clover cut open lengthwise, so as to show the little pod within, very much magnified, and with one valve opened. Tiny as these pods are, they usually contain two, three, or four seeds. Every kind of clover, owing to the richness of these seeds, is much exposed to the attacks of insect encmies. To baffle these wary foes the elovers have invented an extrandinary variety of protective devices, two of which I mean to examine in this essay. Dutch clover meets the difficulty by tucking down the flowers after fertilisation out of the way of the bee, and then retaining the withered corolla or set of petals which completely enclose and hide the pod in the centre. Indeed, such a head as you see in 
No. Io, all composed of brown and withered flowers, looks externally as if it we" : quite dead ; but if you remove or cut open the sere and papery onter parts of the flower, you will find within them a vigorous little sreen pol, in which the miniature peas, after fertilisation, are maturing actively. In fact, the plant is only pretendings to be dead ; yet so effective is the pretence, and so well does the papery covering guard each pod against the egglayirg insects, that l cannot remember ever to have found a single grub in the seeds of clover. This may seem to you a small matter to guard against ; but if you open the seecl-capsules of the common little

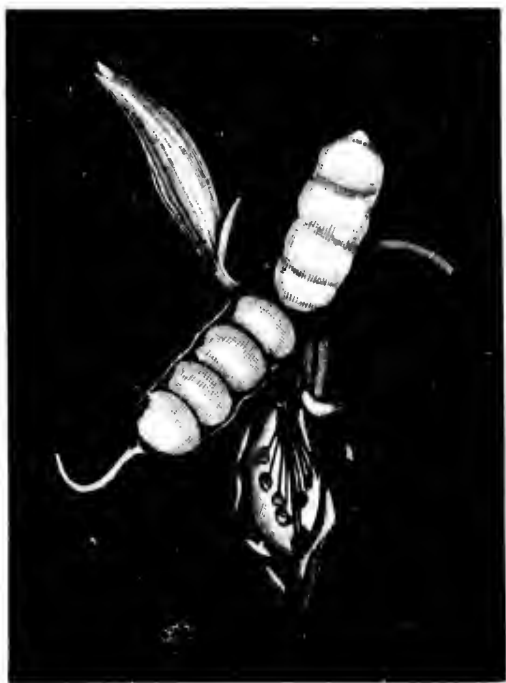

NO. II.-HUTCH CIOTLR, ONE IRS HIOWER (UT OHEX TO SHOW THE

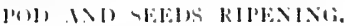
mouse - eatr chickweed, which has no such protection, you will find in almost every capsule a small red grub husily employed in eating the seeds which the plant had laid by for the continuance of its species. It is thus a distinct advantage to the clovers in the struggle for life that they have invented devices 
which enable them to suard their embryo young from the assauts of insects.

Every species of elover-and there are many -luas some dodge of its own for thus protecting its growing pods and seeds from the grubs which would destroy them. I only propose, however, to exannine in detail here one more of these dodges. We have another kind of clover, a good cleal like Dutch clover at a casual glance, and commonly confounded with it by unobservant people, though, ats we shall soon see, the habits and manners of the two kinds are in reality very different. The strawherry clover, as it is called, is a somewhat lower and smaller species than Intch clover, which it resembles in its creeping stems and in its rich foliage. But the flowers are not separately stalked in the head, so that they camnot turn down after fertilisation like those we have just been considering. Moreover, the stems and tlower-heads are much hairier; and this difference is due to the two facts that the strawherry clover is smaller, and has a shorter tube than its Dutch relation. It would thus be easy for ants and other crawling insects to creep up the stem and steal the honey, which is intended for the use of fertilising visitors. To prevent this misfortune, and to keep its nectar for the regular customers, the strawberry clover produces a number of hairs on the stem, which baffle the ants, to whom such hairs are an impenetrable thicket. But you may atsk, "Why are not ants just as good as bees for the clover?" For this reason: flying 
insects are mainly guided by sight and colour; they flit straight from one tlower to another of the same species; and their heads are exactly adapted

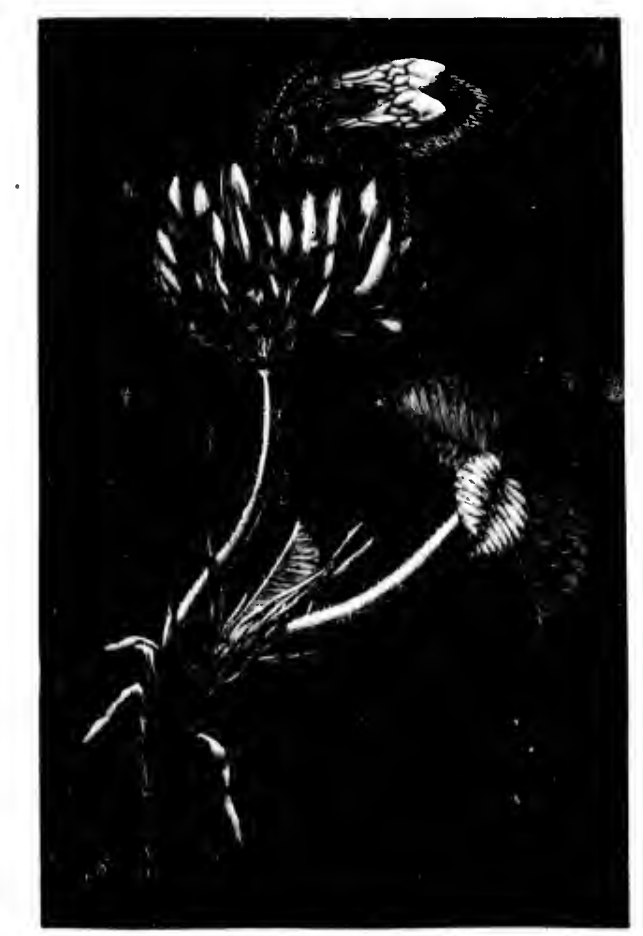

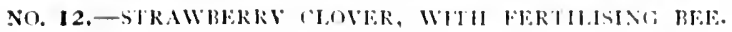

to the shape of the flowers, which in turn have modelled their tubes and organs on purpose to fit them. Ants and creeping insects, on the eontrary, are attracted merely by the sense of smell: they 
noice scent of honey; they climb up all stems indiscriminately in search of it they are barefaced thieves with no organs adapted for carrying pollen; and as they go about in the most reckless

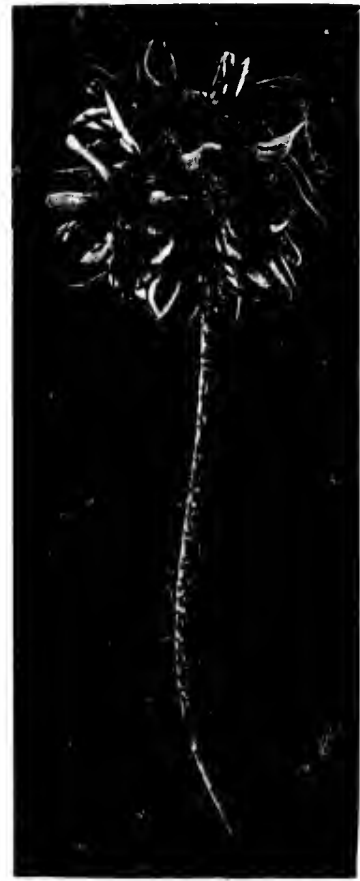

NO, I 3, - STRAWBERKI CIONER BEGINXING; TO SWFI.J. fashion from one kind of plant to another, if they did ever by chance succeed in fertilising a castual flower, they would produce, not true species, but monstrous and meaningless hybrids. Therefore, many plants protect themselves by endless devices against the crawling ants, just ats obviously as they endeavour to allure the winged bees, beetles, and butterflies. I may add that the head of strawberry clover is further protected ayainst climbing insects by a $11 \mathrm{~mm}$ ber of lobed bracts at its base, which effectually disperse these thieving maranclers.

While the strawbery clover is young and but reeently opened, you might easily mistake it for a small and pinky specimen of Dutch clover. If you look closer, however, you will see that the petals are not so large, the tube not so deep, and the calyx much hairier. Never- 
theless, as you may observe in No. I 2, the hairs do not seriously get in the way of the bee during the stage when the flowers are just fit for fertilisation. As soon as tle bee hats left the plant, however, something happens which is quite different to the turning down of the florets in Dutch clover. The calyx or little cup which encloses each separate flower hegins to swell and inflate itself like a balloon or bladder. In No. I 3 you can see the heginnings of this curious process ; each calyx is slightly swelling round the tiny pod which it encloses. In Dutch clover, the pod is longer than the calyx, and the plant trusts for protection to the papery petals or corolla. But in strawherry clover, the calyx, after flowering, becomes very much inflated, thin, and netted; and in this state it conpletely encloses

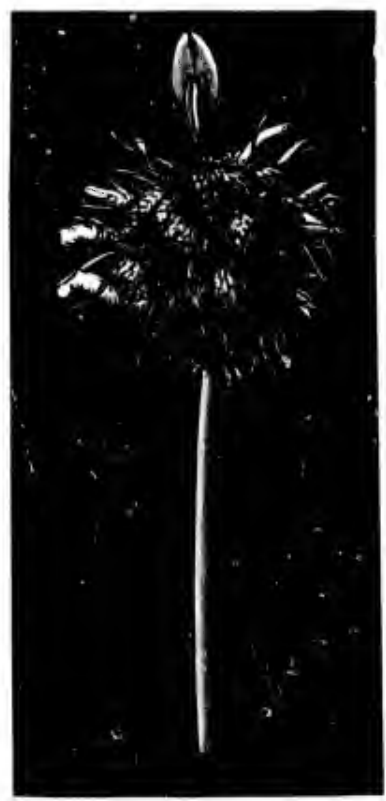

No. 14 -STRAWBERRY CLOVER, NiAIX AN UI.I IAII. the growing pod. No. $1+$ illustrates an intermediate stange in the process, with a solitary old maicl still menfertilised, and the other flowers larger and more intlated. In No. 15 the inflation is complete: each little calyx loas now swelled out into a small balloon, enclosing its pod. 
The whole flower-head then becomes very compact, and assumes a pink tint, so that it somewhat resembles a strawberry, whence its ordinary name, though, as a matter of fact, it is much more like

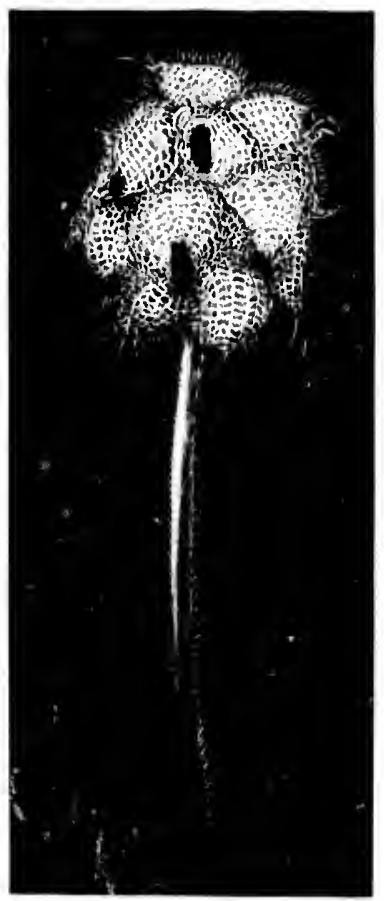

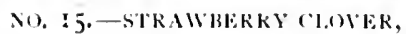
Al. THE FRUTT INFIATEV. a raspherry. You will observe that the beautiful network on the bladclerlike head is closely covered with numerous hairs, which further help to protect the pods from the attacks of insects.

The truth is, Dutch clover is a denizen of rich and lush meadows, where it can take care of itself, and for which alone it is perfectly adapted. Strawberry clover, on the other hand, hats chosen its home in close-cropped pastures, where its creeping habit and low stature help to save it from destruction. The dry and hairy heads are not relished by sheep, and you will often see them left uncropped where the neighbouring foliage has been closely nibbled. The swollen calyx with its hairs also keeps off egglaying enemies. In No. 16 we have an illustration of one such fruiting flower, cut open lengthwise, 
so as to show the way the bladder-like calyx grows out around the pod as it ripens.

Now, what is oddest of all, every one of twenty or twenty-five species of clover hats some dodge of its own for protecting its seeds after fertilisation. This shows how much these rich grants are somght after, and how carefully the plant is compelled to suard them. In some kinds, the calyx is a loose fluff of silky hair, enclosing the pod; in others, it is hard like a nut, or has stiff and pointed lobes which are sharp and prickly. One species closes its hardened lips over the growing seeds and pretends to be empty; a second develops a starry, thistlelike head, with tufts of thick hair, which conceal the swelling pod from observation. But the

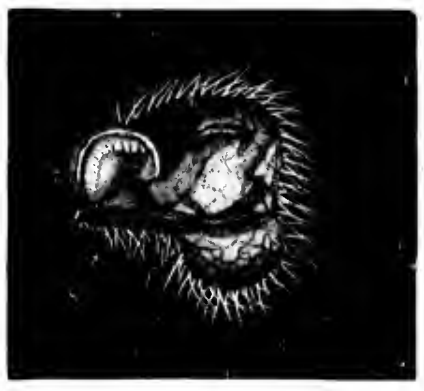

NO. 16. - STRAWBERRY (IONER, A SINGIE INJIATEL FIOWIER CUT OPEN. subterranean clover has

hit upon a still stranger and more ingenious device. It is a little creeping annual, mach addicted to dry pastures or close-cropped hillsides, and particularly common on low knolls or barrows, nibbled over by numerous sheep and donkeys. Under these circumstances, it hats a hard light to protect its nutritious seeds and seedlings. It has taken, therefore, to producings small heads of loose white flowers, which look at first sight like poor 
specimens of Dutch clover. But if you gaze closer you will see that each tiny head consists of two or three properly developed flowers, with four or five undeveloped or abortive blossoms in the centre of the group. These undeveloped blossoms form a sort of living corkscrew. After fertilisation, the stems bend down towards the ground; the corkscrew-like abortive flowers worm their way by pushing into the soil ; the pods are pressed down or buried in the loose mould ; and the plant thus sows its own seed for itself quite as effectually as a gardener could sow it. This is, perhaps, the furthest point which maternal solicitude has ever reached in the vegetable kingdom. 


\section{VI \\ THOSE HORRID EARWIGS}

THS is an age of vindications. Robespierre has been vindicated, and so has Marat; officious aprolosists have attempted to whitewash the mamiahle character of Richard 111. ; Tiberius has been described as "a wise and great ruler" ; and even poor Caligula has been lamely excused, on the ground of insanity, for such playful little freaks as making his favourite saddle-horse a Roman consul. Nobody's reputation is safe nowadays from the vindicator. It is the same in the animal world. New light is constantly being cast on the idiosyncrasies of the rattlesnake; we are assured from day to day that the cobra, though slightly venomous, is an excellent wife and a devoted mother; the scorpion only stings when you put him on the defensive or when he runs for his life; and the tarantula, we are told, hats been most unjustiliably and cruelly blown upon. Has not the poet of "The Bad Boy's Book of Beasts" informed us that-

"The tiger, on the other hand, is kittenish and mild ; He makes a pretty plaything for any little child ; And mothers of large families (who claim to common sense) Will find a tiger well repay the trouble and expense." 
In the midst of all these vindications, shall the harmless, unnecessary earwig go unvindicated from the aspersions that too often assail his character? A thousand times, no! Because he is small, he shall not be insulted with impunity. I see a helpless animal uncluly exposed to vile detractions, and openly pursued with undeserved asperity. The sight arouses all the latent chivalry of my nature. I will gird on my sword to do battle for the right, and rush in, a scientific St. George, in defence of the innocent but persecuted earwig.

That my hero (or heroine) has a bad name in the world 1 am not careful to deny. Calumny has dogged it from its earliest days. Its very name enshrines a myth which is in itself a libel. It is called earwig, gossips will tell you, because it creeps into the ears of incautions sleepers in the open air, and so worms its way to the bran, where, if you will believe the purveyors of folk-lore natural history, it grows to a gigantic size, "as big as a goose's egg," and finally kills its unhappy victim. It is true, science knows nothing of this form of braindisease; it has tried the case before an impartial tribunal, and the earwig has left the court without a stain on its character. Some etymologists have even enclearoured to persuade us that the name earwig itself is but a corruption of ear-wing, a word which they suppose to be derived from the shape of its flying organs. There, however, our philologists are surely crediting the people with more knowledge than they possess ; very few gardeners or countrymen are aware that earwigs have 
wings, while the general puhlic never sees them flying. Besides, the German name Ohroum, or "ear-worm," and the firench l'erce-oreille, or "pierce-ear," sulfice to show that the myth is not confined to our own country. Nll ower the world this harmless and on the whole bencficent creature (for he is at good scarenger) is regatreled with superstitious fear and aversion; all over the world he is ruthlessly destroyed whenever found; and modern science alone is the first to attempt the herculean task of reliabilitating him.

Before you besin to rehabilitate anybody, however, it is first desirable to know something about himself, his family, and his antecedents. I will therefore set out with a brief description of the earwig and his relations. Almost everybody knows well that earwigs are hlack little creeping insects, which frequent dark spots, avoid the light, and love to take refuge under stones or woodwork. The earwig, in point of fact, is a nocturnal animal. Like the bat and the owl, he hides during the daytime, and only prowls forth at night in search of food and adventures. Plain as he is to outward view, his diet might suit the daintiest of poets, for he lives for the most part on the petals of flowers, on which account he is hated with a deadly hatred by gatedeners. But the diet of the race is not wholly floral. Earwigs prefer petals and other soft parts of plants; hut they will put up with leares or growing shoots, and even feed to a small extent on dead or decaying animal matter. That they are fond of fruit you must have observed 
for yourself in the case of peaches and strawherries; though I fancy they never attack a perfect specimen for themselves. My own experience is that they wait till a wasp has bored a hole in the rind of an apricot or a nectarine, and then creep in

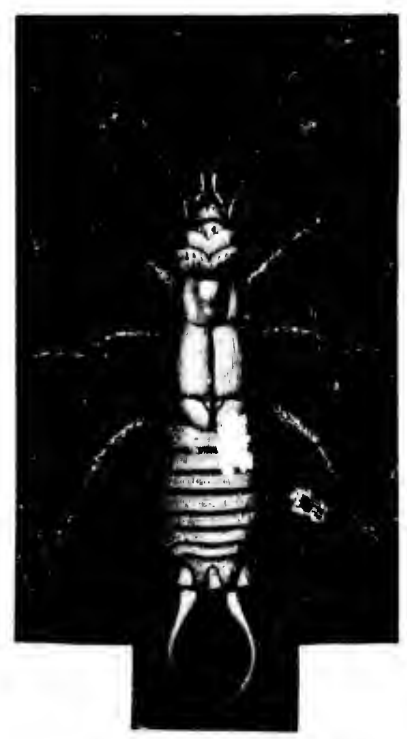
to enlarge it by their adclitional efforts. If on any such occasion, instead of throwing the fruit away in disgust, you will watch the little robbers with a pocket lens, you may (if fortunate) have a chance of observing the mode of action of the mouth organs. 'That is the difference between the point of view of the naturalist and the general public. The outsider says : "What a nuisance! 'This peach is full of earwigs!" The naturalist says: "How

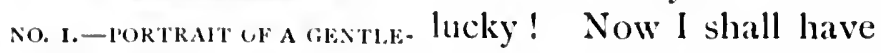
max. (onserve his tall.) a chance of seeing how he uses his manciibles!"

And here let me call your attention in passing to the portrait of a male earwig, the father of a large family, in illustration No. I. You will observe at once for yourself that he has a long body, divided as a whole into three well-demarcated portions. In front comes the head, with 
its two beady-black compound eyes, its round upper lip, its long waving antennae, and its shorter jaw-feelers. Next to the head come the three rings or seguments of the hody proper (called, technically, the thorax), each ring being here provided with a pair of legs, while the two hinder rings bear also wings or wingcases. Last of all comes the abdomen, or tail, with its numerous fiexible rings, of which the male has one more than the female. Notice also the powerful pair of pincers at the extremity of the tail, which are the most conspicuous organs in the full-grown

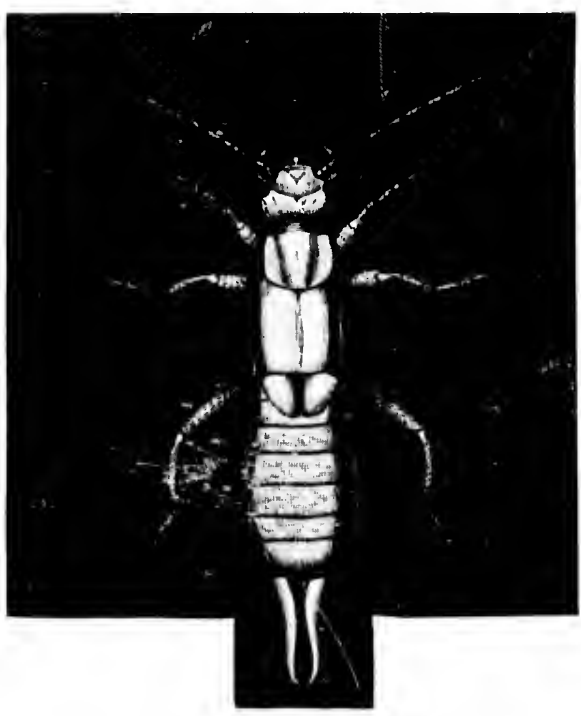
NO. 2,-PORTRAIT OF A LADY. insect : they are more curved in the father of the family than in his faithful spouse, and are likewise provided in his case with curious teeth or indentations. The use and meaning of all these parts will come out in detail as we proceed with our inquiry; for the present, I will content myself with calling 
your attention to the fact that " that horrid earwig" is a far handsomer animal when you come to examine him at close guarters than you were inclined to believe on a casual and disgusted summary inspection. Confess now that his beautifully jointed legs, his translucent thighs, his toothed pincers or forceps, and his feathery antennae are;very much finer than anything you expected from him when you first saw him.

In No. 2 Mr. Enock has given us the comnterfeit presentment of the earwig's wife, for comparison with the portrait of her noble lord. You will observe at a glance that she differs from her mate in two main particulars only. She has one less segment to her tail; and her pincers, which are toothless, are ahmost straight and nearly parallel. The air of distinction which the husband thus gains over his wife is almost as marked as that which is given to man over woman by a couple of inches additional height, and by the noble appendage of a pair of black moustaches. Compare the two as you see them in the illustrations, and you will never again have a doubt as to the real nature of masculine superiority. If you are a man, incleed, I don't suppose you have ever had one. I have called the earwig black, but that is only true on a general survey. In reality, the head is rich chocolate brown, with the many-faceted compound black eyes standing out against it; the legs are amber-coloured, the jointed antenna are pale amber, and the wingcases are transparent or horn-like in colour. 
Now, these two faithful portraits represent the earwig as we all best know him-the common or garden earwig, engaged in crawling about during the hours of sunshine, and seeking some cranny where he may hide himself from the light that irks and distresses him. But there is another side to earwig life which in all probability you have never suspected. While day lasts the earwig shelters himself underground, or lies hid beneath stones or in the crevices of bark. But when night arrives, oh, then he sallies forth, on love and feasts inclined; he seeks his dusky mate, or battens on pink rose-petals. Then is the time to see him flying abroad on expanded wings; and then is the time when he really enjoys existence, till some late-flying swallow or prowling bat puts an end to his brief revels.

"But I never knew earwigs flew!" you exclaim. "I never thought they had wings. Those I have seen were always creeping and crawling."

That is quite true; and in this matter I will not deceive you. The common earwig does really fly; but he is an infrequent aeronaut. Indeed, 1 believe he seldom uses his wings except when he is courting or changing his residence. However, there is a smaller species of earwig, not minutely discriminated from the common sort by housewives and gardeners (who kill all the race impartially), but known to entomologists as Labia minor. This lesser member of the tribe may often be seen disporting himself on the wing on warm afternoons in summer; and even the larger ear- 
wig occasionally ventures out after dark in the same manner. The approved method of taking ear. wigs on the wing is by means of a tarred board, on which they may be canght in small numbers. When the broad transparent wings are expanded, they are really beatiful and striking objects.

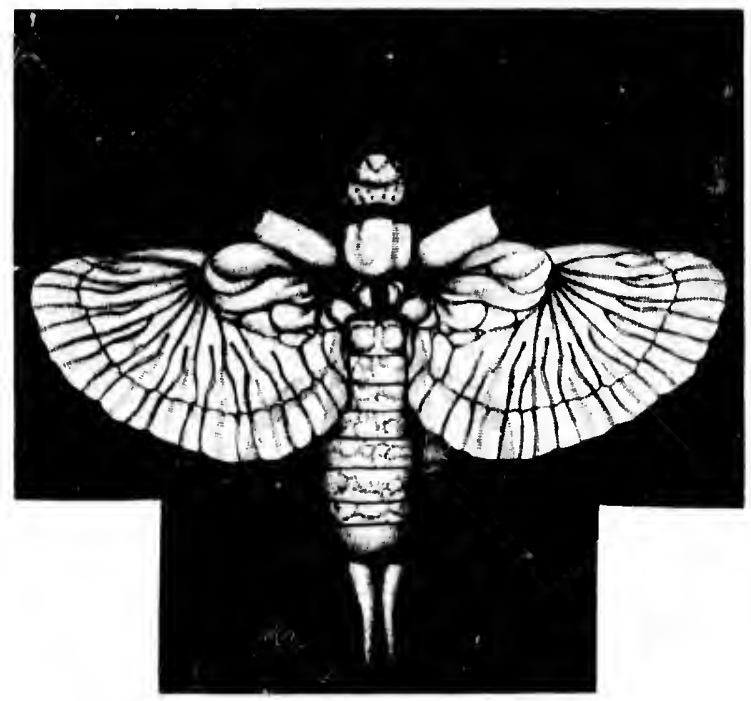

NO. 3.-FENALE EARWIG, WITI HFR WINGS ENPANDED,

What becomes of the wings, however, when the insect is at rest or crawling? Well, they are almost invisibly tucked up in a most curious and marvellous way under the horny outer pair, or wing-cases. In beetles, the horny front pair or wing-cases completely cover and hide the hind 
pair or flying wings. But earwigs are in many ways a less advanced and perfect sroup that the beetle tribe; as we shall see hereafter, they are a rather primitive tribe, only half way "up in the scale of development towards the highest insects. And among their imperfections one may mention

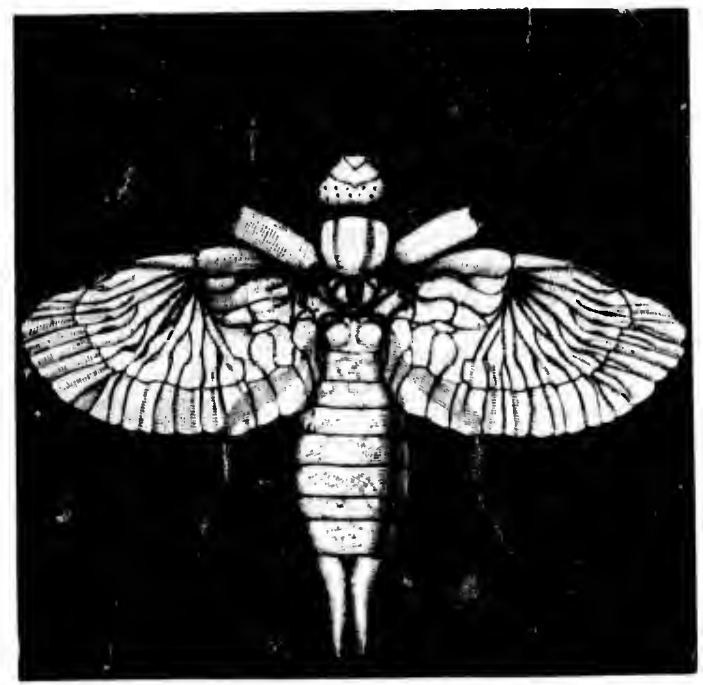

NO. 4.-BEGINNING TO CIOSE.

this-that the hind wings are only partially covered by the front pair or wing-cases.

When I say so, however, I do not mean to be ankind to the earwig, who, within his own limitations (as we say of minor poets), must be loeked upon as one of the most marvellous and complicated of animals. And 1 propose to illus- 
trate this fact for you in a single direction by a hrief eonsideration of the way in which he folds and tucks away his pinoms when he has clone with them.

No. 3 represents a female earwig in flight, with the thin, transparent wings fully expanded. You will notice here

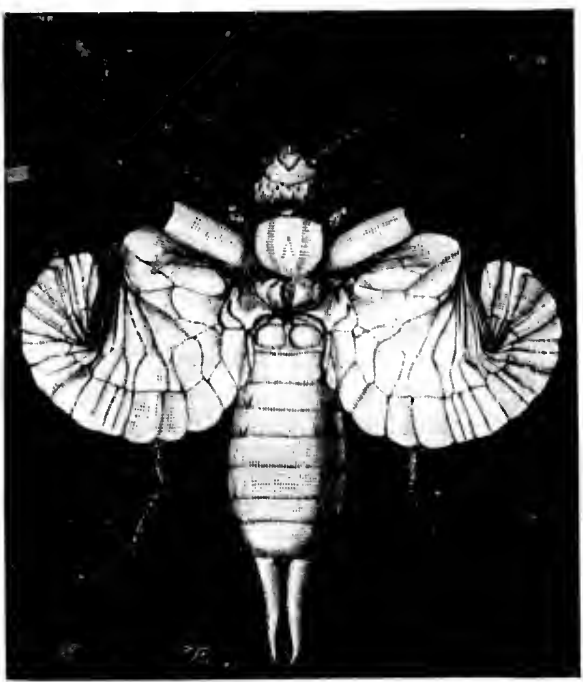

NO. 5-DOUBLING U U THE FORE-WING FANWISE, that the first pair, or wingcases, which are hard and horny, are held open in front out of the way; and that the second pair, or true wings, are flat and papery behind, but have a curious horny rib or "stiffener" in their front portion. 'This stiffener acts exactly like the whalebone or steel in a pair of corsets, or like the ribs in an umbrella. The beautiful folcls and ereases in the true wings resemble those in a fan or Japanese parasol; but they run two ways, some lengthwise, and some transversely. They are exquisitely true in their wrinkles, and 
enable the insect to shut up the wing with perfect accuracy.

No. 4 and the subsequent illustrations show us the various stages in the very complicated closing process; and Mr. Enock has so clrawn them for me as to let us follow in detail every step in this wonderful piece of insect jugglery. Cinquevalli himself does nothing more admirable. To see an earwig close her wings is a study in the perfection of Nature's mechanism. In No. 4 itself, which is the first of the series, the rib or stiffener is just slightly de pressed, so as to

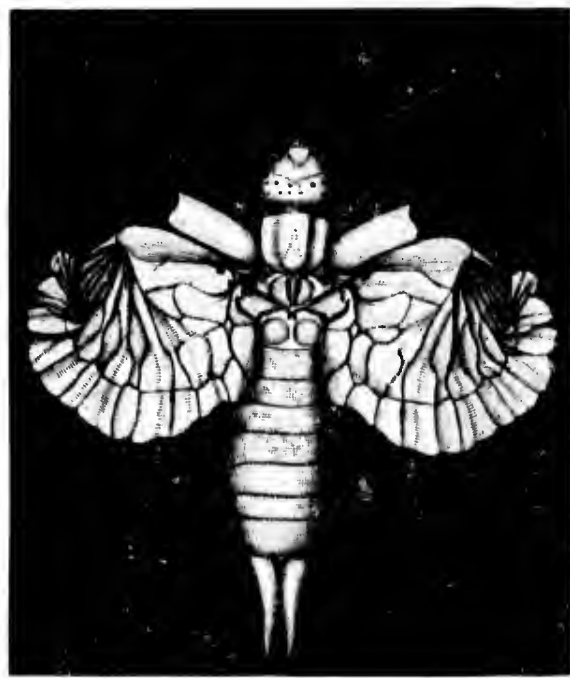
NO. 6.-A STAGE FURTHER. make the tip of the wing drop a little. In No. 5, the stiffener bends at the joint in the midclle, and thus makes the edge of the wing curl inward like a fan, the pleats folding neatly with the utmost precision. With the stage illustrated in No. 6, the wing begins to flap; and in No. 7 , the first part of it disappears round the corner, while 
the remainder turns up like a hinge at the intermediate cross-nerves. In No. 8, we find the wing constricted in the middle hy the process of folding; while in No. 9, the back part hats been nicely tucked awaly behind the front portion, so that the

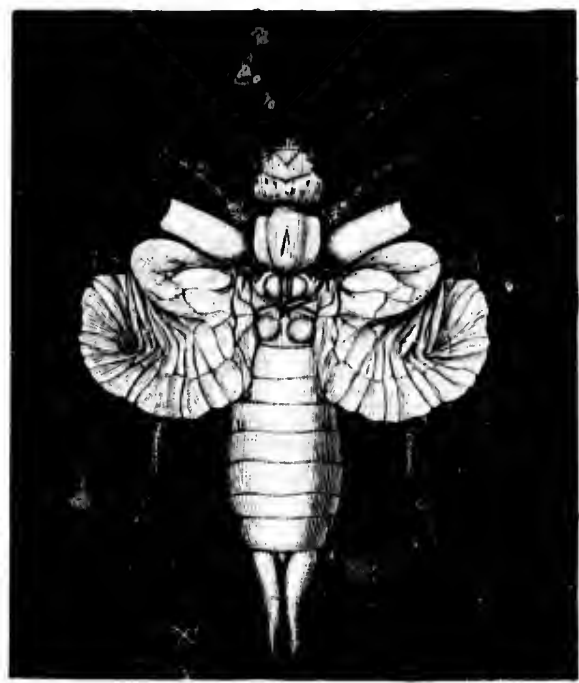

NO. 7.-TIIE BACK PART FOLIINC; HINGE-WISE. whole simulates for at moment a pair of separate wings. In Nos. I o and I I, again, the foldings still continues, till the muscles which move the wings have done as much as they call do in the way of tightening up, by their unaicled efforts. And now comes in the use of the tail with its curious appendages; and very odd it is. The pincers supplement the action of the wing-1nuscles.

As soon as the eamig has reached the point of closing represented in No. 11, she suddenly turns up her tail from behind, ats you can see in No. I2, opens her forceps, and applies the sharp points of the pincers to the recalcitrant 
wing-tip, which will not close of its own mere motion. Then, ats you can observe in No. 13, she rapidly clips the pincers togsether, thus tucking in the last bit of the wing much ats a hand might do it. After that, she straightens her body again, as in No. 14 , and is ready to replace the folded wings behind the hard wing-covers. Of course, all this process, which we have represented here in detail in its various stages, only occupies in life a fell brief seconds; so perfect and so automatic is the mechanism that

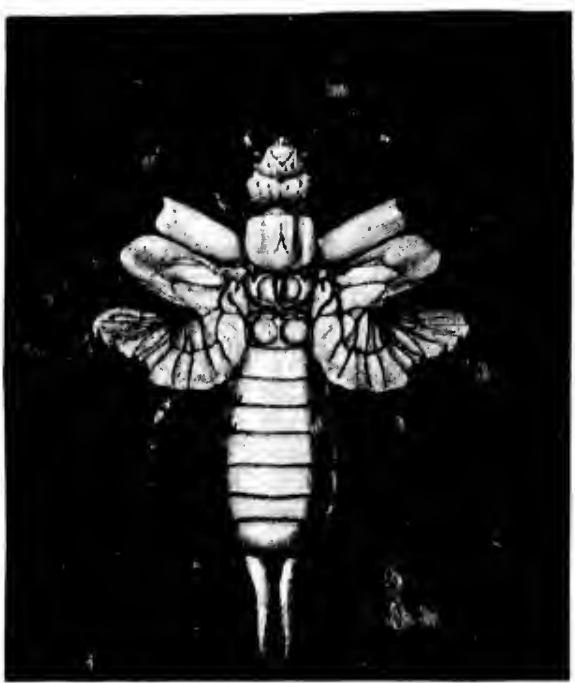

NO. S.-A SLCOND I.ATER. the earwig manages it all as readily as a lady closes up her fan and reopens it.

In No. I 5, our earwigs is shown in the atet of replacing the folded wings over the athdomen; while the hated, horny wins-case is hegimning to cover them. In No. 16 sle lats folded them quite back, but has lifted the wing-catses angain, as if to fly off once more; this illustration exhibits the 
size of the wings when fully folded, and enables you to understand their true relation to the outer wing-cases. Reverting now to No. 2, the mechanism is seen once more completely closed up, and the earwig is prepared to crawl about on the ground in its usual sedate and humdrum manner.

But if, after this,

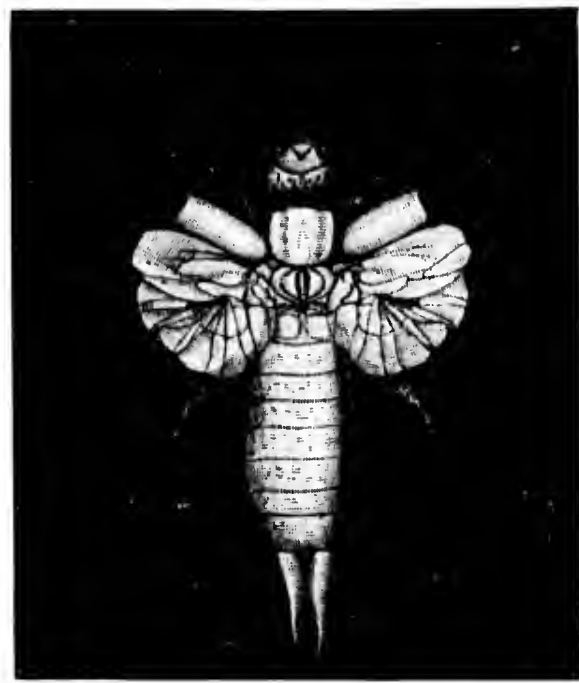

NO. 9. -THE HIND I'ART FULDS BENEATH TILE FORE. you ever despise those horrid earwigs, I shall think you have no taste for the wonderful in nature.

Perhaps, how . ever, the most marvellous point in the history of the female earwig is the fact that she sits on her eggs and takes care of her young exactly as a hen cloes. She retires underground to lay ler eggs, which she deposits in some safe and convenient crannyusually ready-made for her. She is not herself a good cligger, like the mole-cricket, nor has she feet specially adapted for clearing away the soil; she therefore takes advantage of accidental cracks in 
the ground (being a cave-dweller, not an excavator), and is particularly fond of following the disused burrows of earth-worms. You must remember that the surface-soil is literally honeycombed with hurrows of worms, which are not mere looles, but neat small tubes, cylindrical in outline, carefully engineered, and lined throughout with a layer of fine earth, as solid asconcrete. 'The mouth of the burrow is also frequently papered with deald leaves, cemented to the wall hy a sticky secretion from the worm's body. These undersround tunnels often penetrate

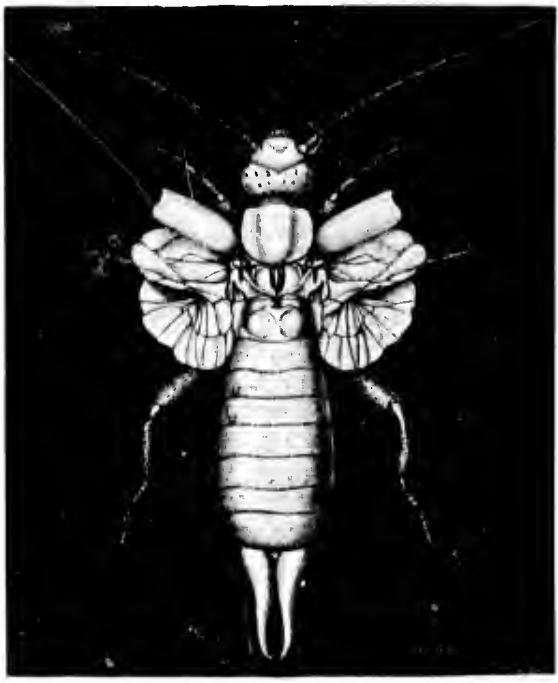

No. 10.-1HE process conTruev. the earth to a depth of many inches, and occasionally go down ats much as six or seren feet. They thus form exectlent approaches or alits, which the earwig can use in prospecting a suitable cranny for her own nursery. If you atsk why the worm does not expel the intruder, or stick up a notice to say that trespassers will be prosecuted, 1 would point ont in reply 
that hundreds of such tumnels are rendered tenantless each day hy means of thrushes, starlings, and other worm-eating hirds, which prowl about lawns, gatrdens, and meatows, picking out the earthworms ats fast ats they show their noses above the level of the soil; while hundreds more are made desolate hy

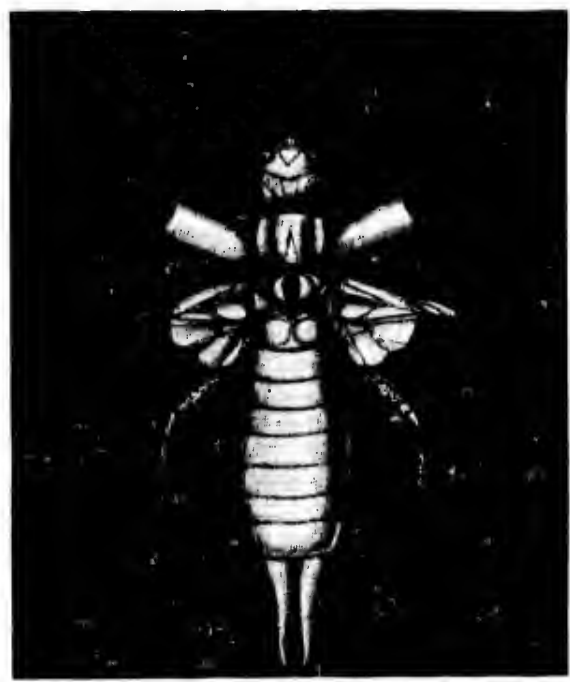

NO. II,-THE WINGS TIIMSEIVES CAN GO NO FURTHER; SOmoles and centipedes. There is thus never any lack of empty burrows which the earwig cim appropriate, as the hermit-crab appropriates the empty shells of whelks andperiwinkles.

In No. I 7 we see the mother earwig safely installed in a nice uncler. ground nest, and sitting like a hen on the eggs she has deposited within it. You can dig up such nests and eggs in any garden in January and February. Mr. Enock tells me he sometimes finds them at a clepth of six inches. The average number of eggrs in a brood runs from fifty to sixty. The 
good mother sits on them till they are all hatehed out, and even then continues to watch them, as a hen does her chicks, till they have arrived at years, or rather weeks, of discretion.

No. 18 is a portrait of the earwig and her numerous family in their first condition. And this picture leads

us up to one most interesting point in the earwig's development. You will notice here that the young insects closely resemble their mother in most respects - far more closely than a caterpillar resembles its butterfly ; they have the

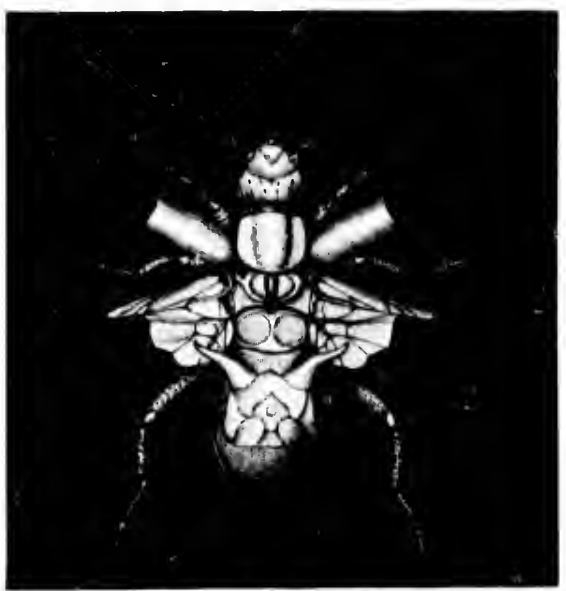

xO. 12. - THE TAIl CONES IN TO HELP THEM. same sort of head, the same sort of body, the same sort of tail, and the same peculiar pincers; but they are quite wingless. Now, this brings out in a very clear way their analogies to and their differences from most higher insects; it enables us to form a distinct idea of the origin of that standing miracle, the metamorphosis of the maggot into the fly and of the caterpillar into the butterfly. 
Some insects have wings, and some have none; hut among insects with none, we may distinguish two classes: those whose progenitors conld $\mathrm{Hy}$, hut who have themselves degenerated so ats to hecome wingless; and those who never had wings at all, but represent the primitive non-flying ancestor. Several

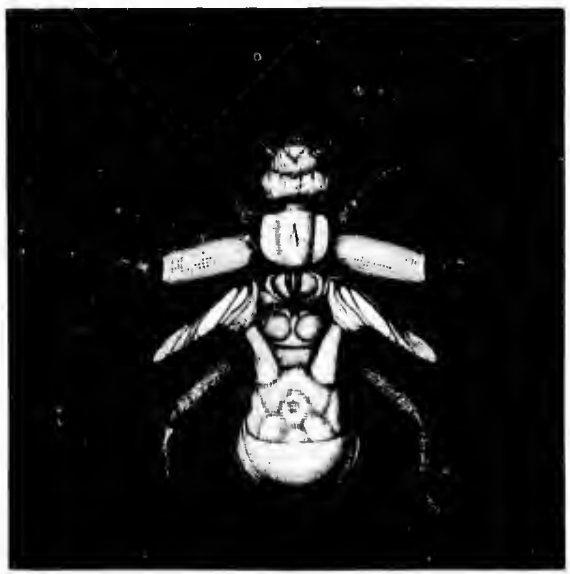
of these carly wingless types still persist to the present day ; and they very closely resemble the young of the earwigs. They hate at head with a couple of watsing antennac ; they have a hody. of three segNO. 13-THE USE GF THE PINCERS. ments, each of which hears at pair of legs, hut no wings ; they have a long, jointed aldomen; and at its end they have two appendages, which, though not specialised into pincers, distinctly sugsest the forceps of the earwis. Indeed, if the baby earwigs always remained in their lirst larval stage, we might easily mistake them for some of these primitive wingless creattures. No. 19 is a rough stetch of such an early type of non-flyings insect, hy name Cimpondea. 
The young earwig, however, does not stop short at this point. When born or hatched from the egg, he closely resembles his parents in most respects, and as he grows and moults, he becomes at each change more and more like them, till at last he is justly considered "the very imatge of his father." At

a certian stage in his development, incleed, we find that (iI) two segments or rings of the body, two prominences or protuberances hegin (1) make their appearanec. These are the rudiments of the wings and wing-eases, which grow gratdlatlly under the

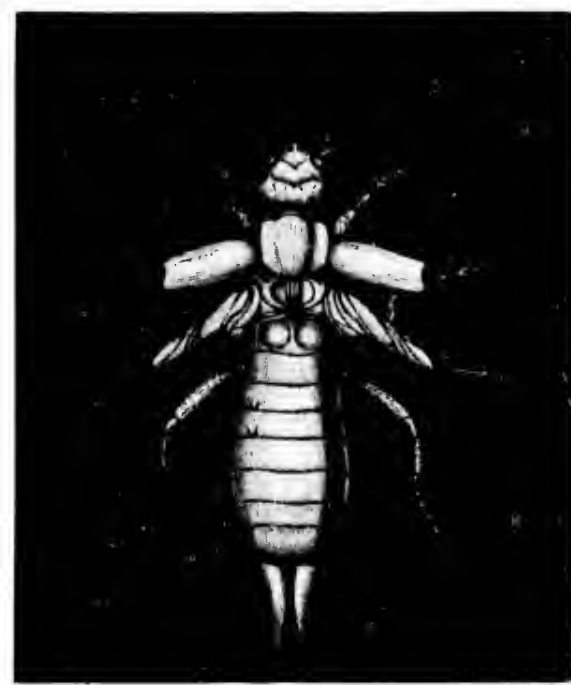

NO. I4. - THE TAII. SIRAHIITLEFI ot? ACAIS. skin, and be-

come fully developed after the latst moultings. We maty fairly take it for sranted, therefore, that in this case the young earwig when first hatched out resembles the original wingless ancestor of the race; hut as time goes on, he hegins to assime the various forms which the race has passed 
through in its advance to the modern winged condition. In other words, the metamorphosis of the individual sums up for us in brief the evolution of the kind.

Observe, however, that the young earwigs do not pass through any distinct and well-marked

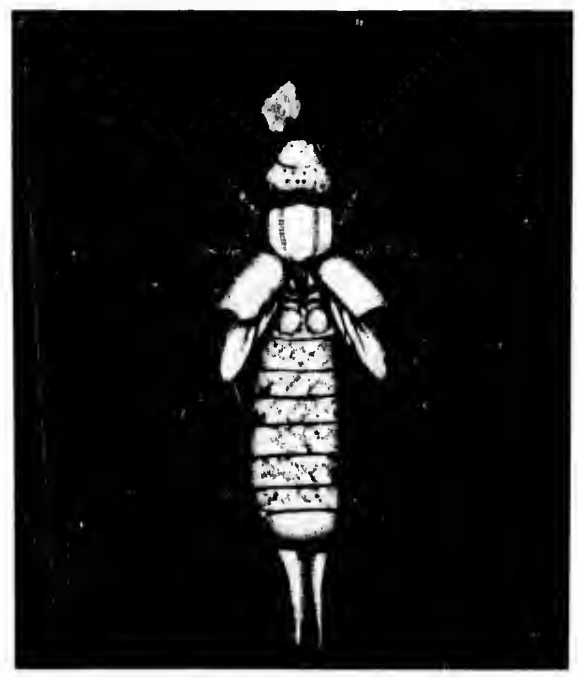

NO. I5-REPIACING THF WINGS BENI.MIU TIIE WING-CASES. stages of larva, pupa, and imago -. grub, chrysalis, and butterfly -- like their more advanced relations. It is true, the names of larva and pupa are frequently given to the two earlier phases in the life of the earwig and its allies. But the terms are misapplied. All that happens to the earwig is a gradual series of successive moults; and during one of these moults the wings mate their appearance. Moreover, the young earwigs when just hatched out of the exg (as you can see in No. I 8) resembles its mother in everything essential sare in the possession of wings. There 
is no real metamorphosis, or a very imperfect one; hardly more change, indeed, than takes place in the growth of humanity; for the acquisition of walking and the addition of a beard and other adult adjuncts may fairly be compared to the development of the wings in the growing earwig. It is quite otherwise with those insects which undergo a complete metamorph. osis, like bees and butterflies. The young grub in the comb does not in the least resemble the fullgrown bee, whether queen or drone, or worker; the caterpillar does not in the

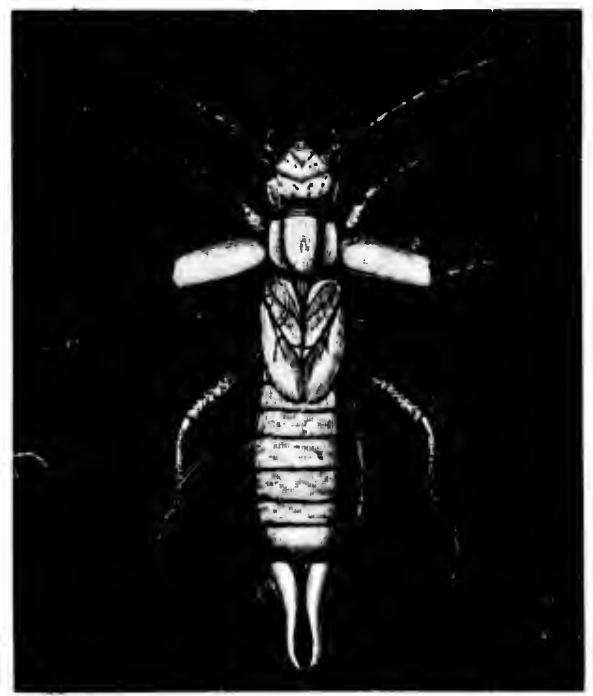

N1) I6.-THE WINGS AT RJist ; THF VING. CASHE RAISLI) ACAIX.

least resemble the beautiful full-grown moth or butterfly.

And here we get another curious piece of crossrelationship; for while the young earwig only "throws back" to a prinitive six-legged, wingless insect, such at the one figured in No. 19, the young bee or butterfly "throws back" to a far 
earlice stage, and is hatehed ont in the form of a cramling worm--a type which must have belonged to a much more original ancestor. It passes the first stage of its life in this worm-like form, but it cloes not grow by slow degrees, like the earwig, into its final shape. On the contrary, it suddenly boxes itself up one day in a pupa-case,

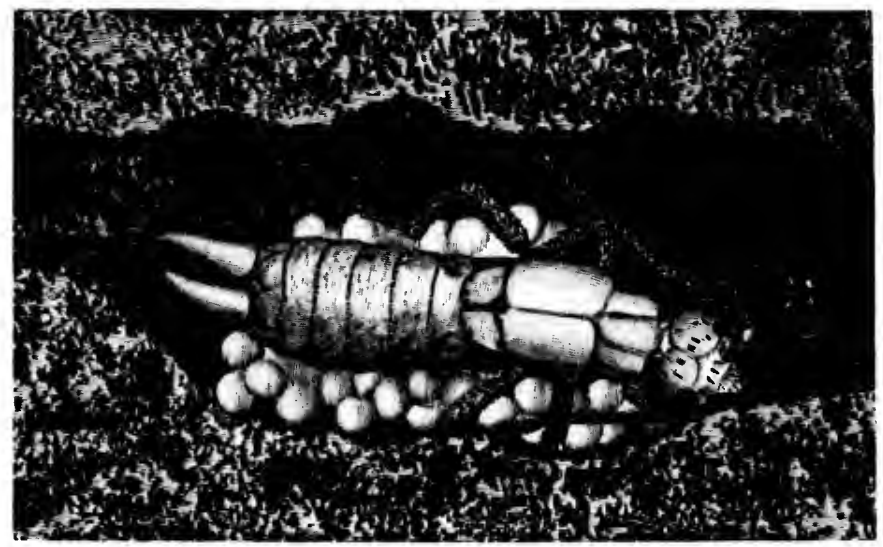

NO. I7.-TIIF MOTHFR FARWII SITTING ON IIFR EGGS.

or chrysalis, lies by dormant for a while, rearranges its parts entirely, and then rapidly develops into a wholly different creature - a hee or watsp, or moth or beetle. 'The carrig's change is growth; the butterfly's is a transformation secue.

How are we to explain these facts? I think in this way. Long, long ago, the common progenitor of all the insect tribes was a worm-like creature, 
with a soft and fleshy body, a few jointed lessis, and the sencral appearance of a grub or caterpillar. To this very ancient and somewhat shadowy ancestor the lavia of the higher insects still more or less revert in their earlier stages; and we may beliere that many insects so reverted during many generations. But in process of time the prinitive

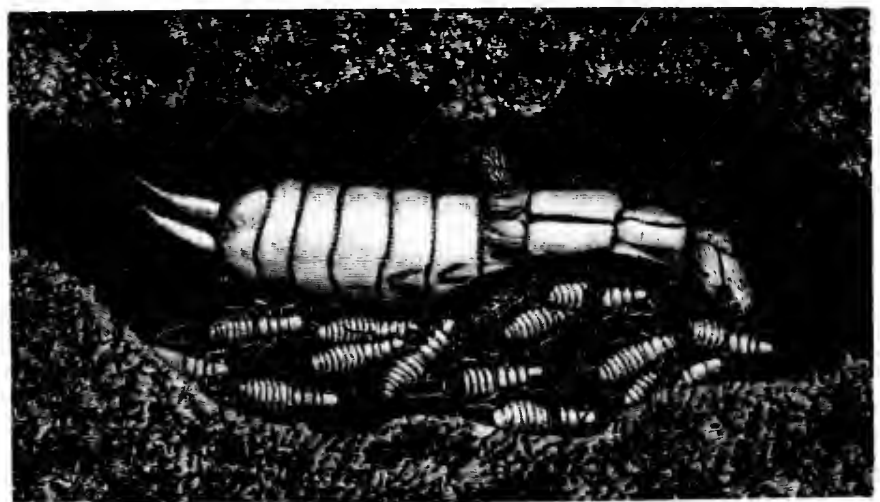

NO. IS.-THE MOTHER EARWIG; ANI IILR BROOU OF CHICKS.

type developed into a wingless, six-legged form, like that in No. 19-a form which you can see at once matrs a comparatively great advance upon the old, worm-like progenitor. This animal, you ann note, hats six good legs to run ahout with, and is already provided with a well-marked head, and with the three body-rings and the long tail or abdomen so characteristic to the last of all higher insects. Its segments have been specialised. From 
such a type, it is probable the earwigs and their allies were developed by natural selection. But to this day every earwig begins life in a shape which closely resembles that of his first six-legged ancestor, and only gradually

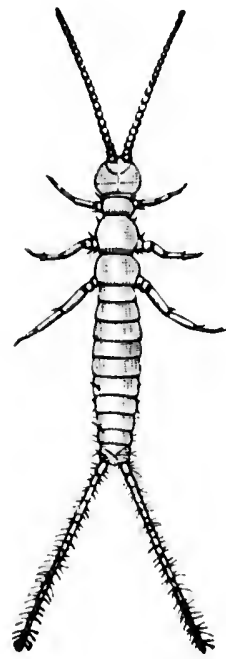

NO. 19.-CAMPODIA, A PRIMITIVE WINGLESS INSECT. acquires his wings and other distinctively earwig-like features.

If you wonder how an animal so small as an earwig can do all the damage it undoubtedly does in garclens, a glance at No. 20 will explain the mystery. You will see from this sketch that the mouth-organs of the little beast are admirably adapted for destroying the petals of your choicest flowers. Nature has provided the earwig with a beautiful series of instruments for cutting holes in leaves and fruits. The figure in No. 20 is the lower part of the mouth, and is covered when at rest by After Sir Join Lubbock. the upper part, which is here placed below it. $M$ are the mandibles or cutting jaw's; they are formidable implements employed to satw holes in leaves, petals, or seed-capsules; while $C$ is the clypeus or shield-in other words, the upper lip, which acts as a patent protector for the whole delicate apparatus. $A S$ are the antennæ sockets, the feelers themselves having been removed for 
the purposes of this sketch. The other parts of the mechanism, I regret to say, can only be described in painfully technical language; but as I am generally sparing in my use of technicalities,

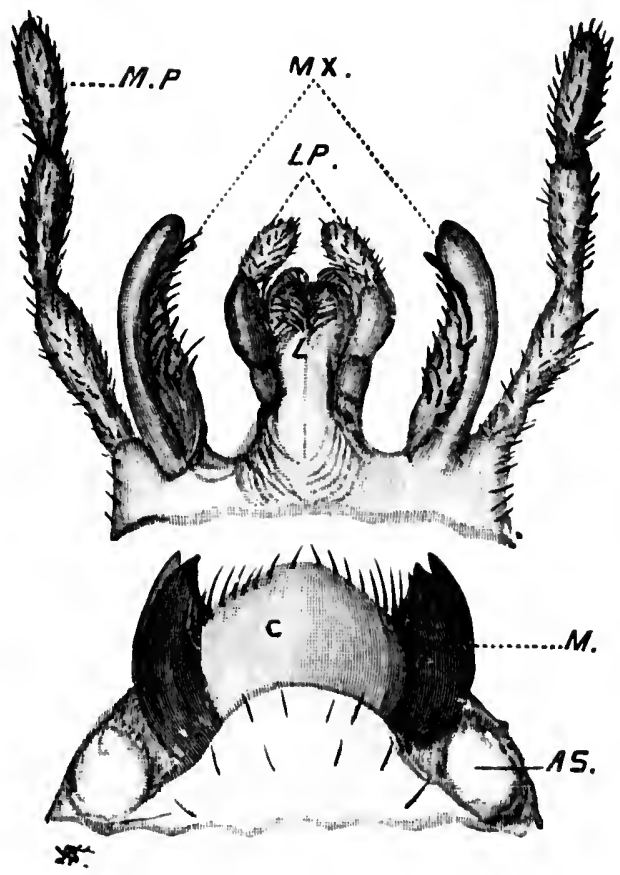

NO, 20.-THE EARWIL'S MUUMH, MSSECTFD.

I trust I may be forgiven this solitary slip on the stound of previous good conduct. $L$ is the labium or lower lip, which closes the mouth from below when it is not in action. $L P$ are the labial palpi, 
used in manipulating the morsel as it is being eaten. MX are the maxilar, or trone jaws, employed in masticating the food, and answering in their functions pretty closely to the teeth of higher animals. Last of all, $M^{\prime \prime}$ are the maxillary palpi, chiefly used like a pair of forks in holding the food, and, perhaps, atso in deciding whether it is fit for eating. From this brief clescription, it will be immediately obvious to you that feeding with the earwis is a solemu and very complicated process. It is earried on by a number of clistinct organs and implements, the exact purposes of each of which are only known at full to the insect which uies them.

I should atd that the anteme or feelers (not included in this last sketch, but conspicuous in all the previous illustrations) are in all likelihoo:l sense-organs, whose precise nature has never been altogether established. Some naturalists believe that they are used as organs of smell ; others that they are combined organs of touch and guilance; yet others, that they are the seat of a "sixth sense" unknown to humanity. However this may be, it is at least certain that they are useful as a means of communication between the insect himself and his mate, his young, his friends, and his acquaintances. Earwigs clearly feel their way, to a great extent, hy the aid of the antemue, and also recognise through them their visitors and family. They use them, too, in caressing or fondling their mates and their children. It is known that the antemna are provided with numerous nerve-terminals, as is always 
the case with organs of the senses: and I beliere myself that, hy their means, all insects of the same species are able to communicate more or less with one another by established signals. Perhaps the antennae emit peculiar perfumes, which are recosnised in turn by those of the friend or mate ; perhaps it is by touches and strokes that the insects transmit their icleas to one another. But that they do transmit icleas, nobody who has watched them closely cree cloubts for a moment, and many maturalists even use the word "tallings" of the parleys which ants and other insects carry on with their feelers.

It may be thought that an earwig's life, like a policeman's, " is not a happy one." 'This I hold to be an error. 'The earwig lores damp and darkness, it is true, but he flies at night in the beautiful twilight or by the soft rays of the moon, while his (ays are solaced by the companionship of his mate and his chosen comrades, for they are sregarious creatures. The mother tends her young with the assicluity of a hen sitting on her chickens, and food being abundant and cheap, life runs, as a rule, fairly smoothly with the earwig. 


\section{VII}

\section{THE FIRST PAPER - MAKER}

7 HE civilised world could hardly get on nowadays without paper; yet papermaking is, humanly speaking, a very recent invention. It dates, at furthest, back to the ancient Egyptians. “Humanly speaking," I say, not without a set purpose; because man was anticipated as a paper-maker by many millions of years; long before a human foot trod the earth, there is reason to suppose that ancestral wasps were manufacturing paper, almost as they manufacture it for their nests to-day, among the subtropical vegetation of an older and warmer Europe. And the wasp is so clever and so many-sided a creature, that to consider him (or more accurately her) in every aspect of life within the space of a few pages would be practically impossible. So it is mainly as a paper-manufacturer and a consumer of paper that I propose to regard our slim-waisted friend in this chapter.

It is usual in human language to admit, as the Latin Grammar ungallantly puts it, that " the masculine is worthier than the feminine, the feminine than the neuter." Among wasps, however, the 
opposite principle is so clearly true-the queen or female is so much more important a person in the complex community, and so much more in evidence than the drone or male-that 1 shall offer no apology here for setting her history hefore you first, and giving it precedence over that of her vastly inferior hushand. Place aux dames is in this instance no question of mere external chivalrous courtesy ; it expresses the simple truth of nature, that, in wasp life, the grey mare is the better horse, and hears acknowledged rule in her own city household. Not only so, hut painful as it may sound to my men readers, and insulting to our boasted masculine superiority, the neuter in this case ranks second to the feminine; for the worker wasps, which are practically sexless, heing abortive females, are far more valuable members of the community than their almost useless fathers and brothers. I call them neuter, because they are so to all intents and purposes: though for some unknown reason that seemingly harmless word acts upon most entomologists like a red rag on the prosertial bull. They will allow you to describe the abortive female as a worker only.

In No. I, therefore, 1 give an illustration of a queen wasp; together with figures of her husbaid and of her unmarriaseable daughter. The queen or mother wasp is much the largest of the three; and you will understand that she needs to be so, when you come to karn how much she has to do, how many eggss she has to lay ; and how, matided, this brave foundress of a family not only builds a city 
and peoples it with thousands of citizens, but also

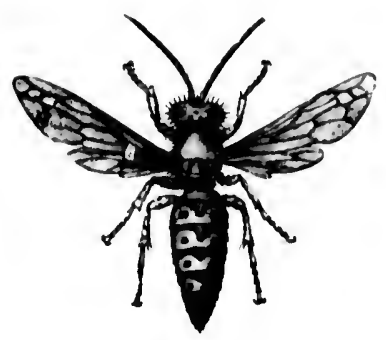

. Wale

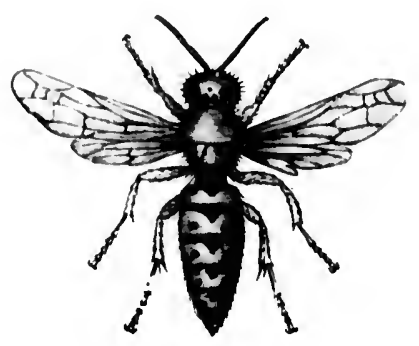

(li in.

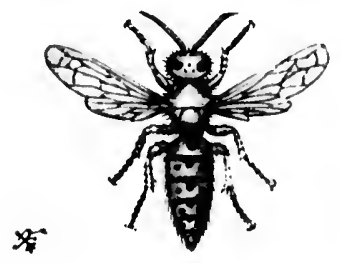

Hiker.

NO. I.-FAMIIY POKTRAITS OF THE: WASts. feeds and tends it with her ow'n overworked mouthI cannot honestly say her hands - till her maiden daughters are of age to helpher. IVomen's-rights women may be proud of the example thus set them. Nature nowhere presents 11s, incleed, with a fince specimen of feminine inclustry and maternal devotion to cluty than in the case of these comageous and pugnacious insects.

But I will not now enlarge upon the features of these three faithful portraits, "expressed alter the life," as Elizabethan writers put it, becaluse as we proceed I shall have to call attention in greater detail to the meaning of the various parts of the body. It must sulfice for the moment to direct your notice here to that very familiar portion of the Wasp's anatomy, the sting, or ovipositor, possessed hy the females, both per- 
fect and imperfect-eneens or workers-but not by those defenceless creatures, the males. The nature of the sting (so far as it is not alleady well known to most of us hy pungent experience) 1 will enter into later ; it must subfiec for the present to say that it is in essence an instrument for depositing the eggss, and that it is only incidentally turned inte a weapon of effence or defence, and a means of stmmong or paralysing the prey or food-insects.

The first thing to understand ahout a commonnity of wasps is the way it originates. The story is a strange one. When the first frosts set in, almost all the wasps in temperate comntries die off to a worker from the effects of colds. The chill winds nip them. For a few days in antumn you may often notice the last straggling survivors crawlins fechly about, very uncomfortable and numb from the cold, and with their temper somewhat somed by the conscionsuress of their own exceeding weakness. In this irritable condition, feeling their latter end draw nigh, they are giving to using their stings with waspish virulence on the smallest provocation ; they more alout half-dazed on the damp ground, or lie torpid in their nests till death overtakes them. Of the whole populous eity which hummed with life and business hut a few wecks earlier, no more than two or three survivors at the outside struggle somehow through the winter, to carry on the race of wasps to succeeding genelations. The colder the season, the fewer the stragglers who live it out; in open 
winters, on the contrary, a fair number doze it through, to become the foundresses of correspondingly numerous colonies.

And who are these survivors? Not the lordly and idle drones; not even the industrious neuters or workers; but the perfect females or queens, the teeming mothers to be of the coming communities. Look at the royal lady figured in No. 1. As autumn approaches, this vigorous young queen weds one of the males from her native nest. But shortly afterwards, he and all the workers of his city fall victims at once to the frosts of October. They perish like Nineveh. The queen, however, bearing all the hopes of the race, cannot afford to fling away her precious life so carelessly. That is not the way of queens. She seeks out some sheltered spot amons dry moss, or in the crannies of the earth-a sandy soil preferred-where she may hibernate safely. There, if she has luck, she passes the winter, dormant, without serious mishap. Of course, snow and frost destroy not a few such solitary hermits; a heavy rain may drown her; a bird may discover her chosen retreat; a passing animal may crush her. But in favourable circumstances, a certain number of queens do manage to struggle safely through the colder months; and the wasp-supply of the next season mainly depends upon the proportion of such lucky ladies that escape in the end all winter dangers. Each queen that lives through the hard times hecomes in spring the foundress of a separate colony ; and it is on this account that farmers and fruit-growers often 
pay a small reward for every queen wasp killed early in the spring. A single mother wasp destroyed in May is equivalent to a whole nest destroyed in July or August.

As soon as warmer weather sets in, the dormant queen awakes, shakes off dull sloth, and forgets her long torpor. With a toss and a shake, she crawls out into the sumshine, which soon revives her. Then she creeps up a blade of grass, spreads her wings, and flies off. Her first care is naturally breakfast; and as she has eaten nothing for five months, her hunger is no doubt justifiable. As soon, however, as she has satisfied the most pressing wants of her own nature, maternal instinct goads her on to provide at once for her unborn family. She seeks a site for her nest, her future city. How she builds it, and of what materials, I will tell you in greater detail hereafter ; for the moment, I want you to understand the magnitude of the task this female Columbus sets herself-Columbus, Cornelia, and Caesar in one-the task not only of building a Carthage, but also of peopling it. She bas no hands to speak of but her mouth, which acts at once as mouth, and hands, and tools, and factory, and stands her in good stead in her carpentering and masonry. She does everything with her mouth ; and therefore, of course, she hats a mouth which has grown gradually adapted for doing everything. The monkey used his thumb till he made a hand of it; the elephant his trunk till he could pick up a needle. Use brings structure; by dint of using her mouth so much, the wasp hats 
acquired both organs fit for her, and dexterity in employing them.

The first point she has now to consider is the placing of her nest. In this she is guided partly by that inherited experience which we describe (somewhat foolishly) as instinct, and partly by her own individual intelligence. Different races of wasps prefer different situations: some of them burrow underground; others hang their houses in the branches of trees; others again seek some dry and hollow trunk. But personal taste has also much to do with it; thus the common English wasp sometimes huilds underground, but sometimes takes advantage of the dry space under the eaves of houses. All that is needed is shelter, especially from rain; wherever the wasp finds a site that pleases her, there she founds her family.

Let us imagine, then, that she has lighted on a suitable hole in the earth-a hole produced by accident, or by some dead mole or mouse or rabbit; she occupies it at once, and begins by her own lahom to enlarge and adapt it to her private requirements. As soon as she has made it as hig as she thinks necessary, she sets to work to collect materials for building the city. She flies abroad, and with her saw-like jaws rasps away at a paling or other exposed piece of wood till she has collected a fair amount of finely powdered fibrous matter. I will show you later on the admirable machine with which she scrapes and pulps the fragments of wood-fibre. Having gathered a sufficient quantity of this raw material 
to begin manufacturing, she proceeds to work it up with her various jaws and a secretion from her mouth into a sort of coarse brown paper; the stickiness of the secretion gums the tiny fragments of wood together into a thin layer. Then she lays down the floor of her nest, and proceeds to raise upon it a stout column or foot-stalk of papery matter, sufficiently strong to support the first two or three layers of cells. She never builds on the ground, hut hegins her nest at the top of the supporting column. The cells are exclusively intended for the reception of eggs and the breeding of grubs, not (as is the case with hees) for the storing of honey. We must remember, however, that the original use of all cells wats that of rearing the young; the more advanced bees, who are the civilised type of their kind, make more cells than they need for strictly nursery purposes, and then employ some of them as convenient honey jars. The consequence is that beebives survive !intact from season to season (unless killed off artificially), while the less prodent wisps die wholesale by eityfuls at the end of each summer.

Having thus supplied a foundation for her topsyturvy city, our wasp-cueen proceeds in due course to build it. At the top of the original column, or foot-stalk, she constructs her earliest eells, the nurseries for her three first-horn srubs. They are not built upward, however, ahove the foot-stalk, but downward, with the open mouth below, hanging like a bell. Fach is short and shallow, about a tenth of an inch in depth to begin with, and 


\section{56}

Flashlights ox Natrire

more like a cup, or even a saucer, than a cell at this early stage. The Natural History Museum at South Rensington possesses some admirable examples of such nests, in various degrees of growth; and my fellow-worker, Mr. Enock, has obtained the kind permission of the anthorities at

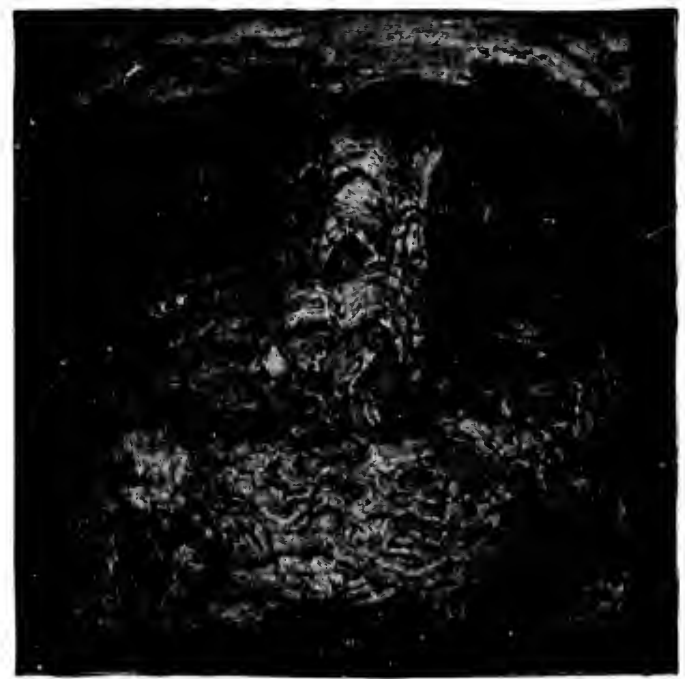

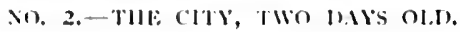

the Museum to photograph the cases which contain them, for the purposes of these articles. They represent the progress of the yueen-wasp's work at two, fire, and fifteen days respectively (Nos. 2, 3, and 4 ), and thus almirahly illustrate the incredible rapidity with which, alone and maided, she huilds and populates this one-mother city. 
As soon as the first cells are formed in their early shallow shape, the husy mother, sallying forth once more in search of wood or libe, proceeds to make more paper-pulp, and construct an umbrella-slatped covering above the three sallecers. In each of the three she lays an egg ; and then, leaving the eggss to

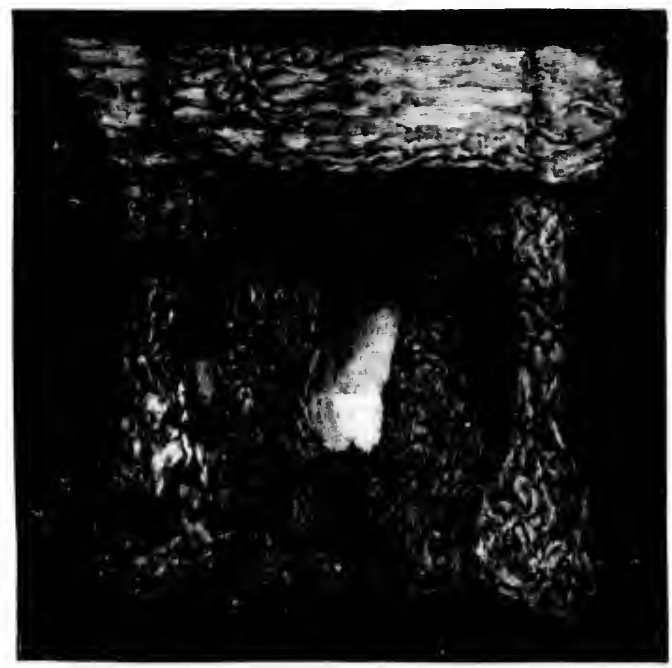

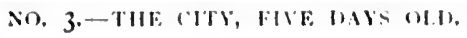

hatch out yuietly by themselven into barve, she goes on cutting-not bread and hutter, like Charlotte in Thackeray's song - hut more wood-fibe to matic more cells and more coverings. These new eells she hangs up beside the original three, and lays an egg in each as soon at it is completed. But a mother's work is never finished; and surely there 
wats never a mother so hardly tasked as the royal wasp foundress. By the time she hats built and stocked a fer more cells, the three eggs first latid have duly hatched out, and now she must begin to look after the little grabs or larve. I have not illustrated this earliest stage of wasp-life, the

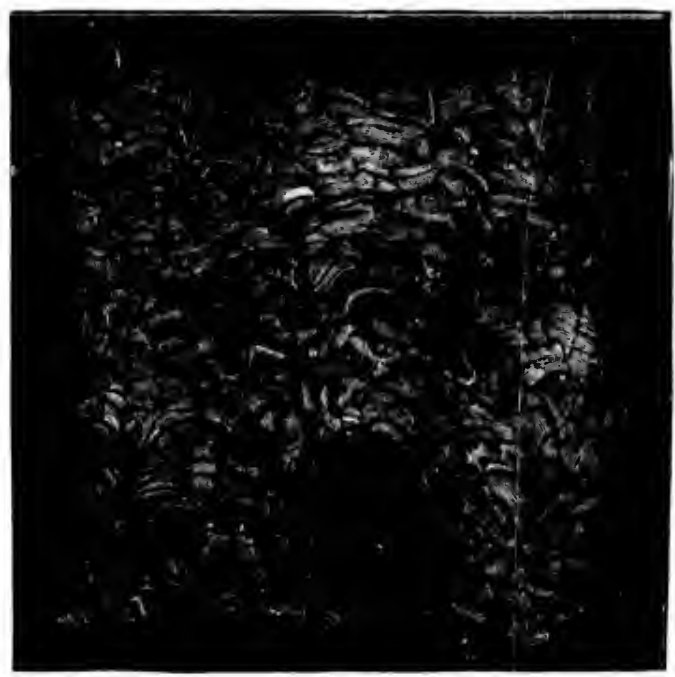

NO, 4-THF CITY, FIFTEEN DAYS OLI).

grubby or nursery period, because everybody knows it well in real life. Now, as the grubs hatch out, they require to be $\mathrm{fecl}$, and the poor, overworked mother has henceforth not only to find food for herself, and paper to build more cells, but also to feed her helpless, worm-like 
offspring. There they lie in their cradles, head downward, erying always for provender, like the daughters of the horse-lecel, Forgive her, therefore, if her temper is sometimes short, and if she resents intrusion upon the strawbery she is carting away to feed her young family by a hasty sting, administered, perhaps, with rather more asperity than a lady slonld display under trying circomstances. Some of my readers are mothers themselves, and call feel for her. Nor is even this all. The grubs of wasps grow fast-in itself a testimomial to the eonstant eate whth which a devoted mother feeds and tends them: and eren ats they grow the poor queen (at queen but in name, and more like a matid-of-all-work in reality) has continually to raise the cell-wall around them. What looked at first like shallow cups, thus grow at last into deep, hollow cells, the walls being raised from time to time by the addition of papery matter, with the growth of the inmates. In this first or foundation-comb-the nucleus and original avenue of the nascent city-the walls are never carried higher than the height of the larva that inhabits them. As the grub grows, the mother adds datily a course or layer of paper, till the larva reaches its final si\%e, a fat, full srub, ready to undergo its marvellous metamopphosis. Then at latst it begins to do some work on its own accoumt it spins a silky, or cottony, web, with which it covers over the mouth or opening of the cell; though even here you must remember it derives the material from its own body, and therefore 
ultimately from food supplied it by the mother. How one wasp can ever do so much in so short a time is a marvel to all who have once watched the process.

While the baby wasps remain swaddled in their cradle cells, their food consists in part of honey, which the careful mother distributes to them impartially, turn about, and in part of succulent fruits, such as the pulp of pears or peaches. The honey our housekeeper either gathers for herself or else steals from bees, for truth compels me to admit that she is as dishonest as she is industrious; but on the whole, slie collects more than she robs, for many flowers lay themselves out especially for wasps, and are adlapted only for fertilisation by these special visitants. Such specialised waspflowers have usually small helmet-shaped blossoms, exactly firted to the head of the wasp, as you see it in Mr. Enock's illustrations; and they are for the most part somewhat livid and dead-meaty in hue. Common scrophularia, or fig-wort, is a good example of a plant that thus lays itself out to encourage the visits of wasps ; it has small lurid-red flowers, just the shape and size of the wasp's head, and its stamens and style are so arranged that when the wasp rifles the honey at the hase of the helmet, she cannot fail to brush off the pollen from one blossom on to the sensitive surface of the next. Moreover, the scrophularia comes into hloom at the exact time of year when the bahy wasps require its honey; and you can never watch a scrophularia plant for three 
minutes together without seeing at least two or three wasps busily engaged in gathering its neetar. Herb and insect have learned to accommodate one another; by mutual adaptation they have fitted each part of each to each in the most marrellous detail.

It is a peculiarity of the wasps, however, that they are fairly ommivorous. Most of their cousins, like the bees, have mouths adapted to honey-sucking alone-mere tubes or suction-pumps, incapable of biting through any hard substance. But the wasp, with her hungry large family to keep, has to be less particular about the nature of her food; she cannot afford to depend upon honey only. Not only does she snck nectar ; she hites holes in fruits, as we know to our cost in our gardens, te dig out the pulp; and she has a perfect genius for selecting the softest and sumniest side of an apricot or a nectarine. She is not a strict regetarian, either ; all is fish that comes to her net: she will help herself to meat or any other animal matter she can find, and will feed her uncomplaining grubs upon raw and bleeding tissue. Nay, more, she catches Hies and other insects as they thit in the sunshine, saws off their wings with her sharp jaws, and carries them off alive, but incapable of struggling, to feed her own ever-increasing household.

By-and-by the first grubs, which covered themselves in with silk in order to undergo their pupa or chrysalis stage, develop thei: wings under cover, and emerge from their cases as full-grown workers. These workers, whose portrait you will find on a 
previous patge, are partially dereloped females, heing mathe to lay eggs. But in all other respects they inherit the habits or instincts of their estimable mother ; and no sooner are they fairly hatehed ont of the pupa-case, where they underwent their rapid metamorphosis, than they set to work, like dutiful daughters, to assist mamma in the management of the city. Like the imagined world of Tennyson's "Princess," no male can enter. If ever there was a woman-ruled republic in the world, stach as Aristophanes feigned, it is a watsp's nest. The workers fall to at "tidying up" at once; they put the house in order; they go out and gather paper; they help their mother to build new cells; and they atsist in feeding and tending the stillincreasing nursery. The first comb formed, you will remember, wats at the top of the foundation column or footstalk; the newer combs are built below this in rows, each opening downward, so that the compound house or series of flats is planned on the exactly opposite system from on own-the top storeys being erected first, and the lower ones afterward, each storey having its floor above and its entrance at the bottom. At the same time, the umbrella-shaped covering is continued downward as an outer wall to protect the combs, until finally the nest grows to be a roughly romel or egg-shaped body, entirely enclesed in a shell or outer wall of paper, and with only a single gateway at the bottom, by which the busy workers so in and out of their city.

The nest of the tree-wasp, which we have also 
been kindly permitted to photograph from the specimens at the Natural History Musemm (Nos. 5 and 6), exhibits this final stage of the compound home.

By the time the workers have become tolerably numerous in the growing nest, the busy mother and queen begins to relax her external efforts, and confines herself more and more to the performance of her internal and domestic duties. She no longer goes out to make paper and collect food ; she gives herself up, like the queen bee, exclusively to the maternal business of egg-laying. You must remember that she is still the only perfect female in the wasp hive, and that every worker wasp the home contains is her own danghter. She is foundress, yueen, and mother to that whole busy community of tooo or 5000 souls. The longer the nest goes on, the greater is the number of workers produced, and the faster cloes the queen lay eggs in the new cells now built for her use by her attentive daughters. These in turn fly abroad everywhere in search of nectar, fruits, and meat, or gather honey-dew from the green-flies, or eatch and sting to death other insects, or swoop down upon and carry off fat, juicy spiders; all of which foodstuffs, save what they require for their own subsistence, they take home to the nest to feed the grubs, from which, in due time, will issue forth more workers. It is a wonderful world of women burghers.

As long as summer lasts, our queen lays eggs which produce nothing else than such reuter 
164 Flashlights on Nat'Re

workers. As atutumn comes on, however, and the future of the race must be provided for, she lays eggs which hateh out a brood of perfect females or queens like herself. It is probable that the same egg may develop either into a queen or a worker, and that the difference of type is due to

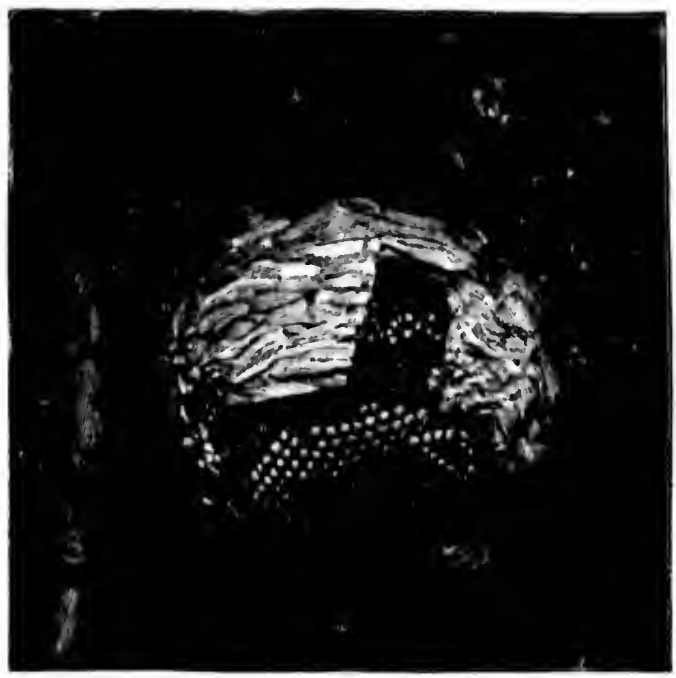

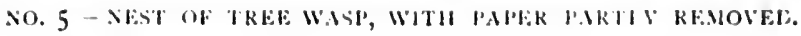

the nature of the food and training. A young grub fed on ordinary food in an ordinary cell becomes a neuter : but a similar grub, fed on royal food and cradled in a larger cell, develops into a queen. As with ourselves, in fact, royalty is merely a matter of the surroundings. 
Last of all, as the really cold weather hegins to set in, the queen watsp latys some other eggs from which a small hrood of males is finally developed. Nohody in the nest sets much store by these males: they are necessary evils, no more, so the wasps put up with them. It is humiliating to my sex, but 1

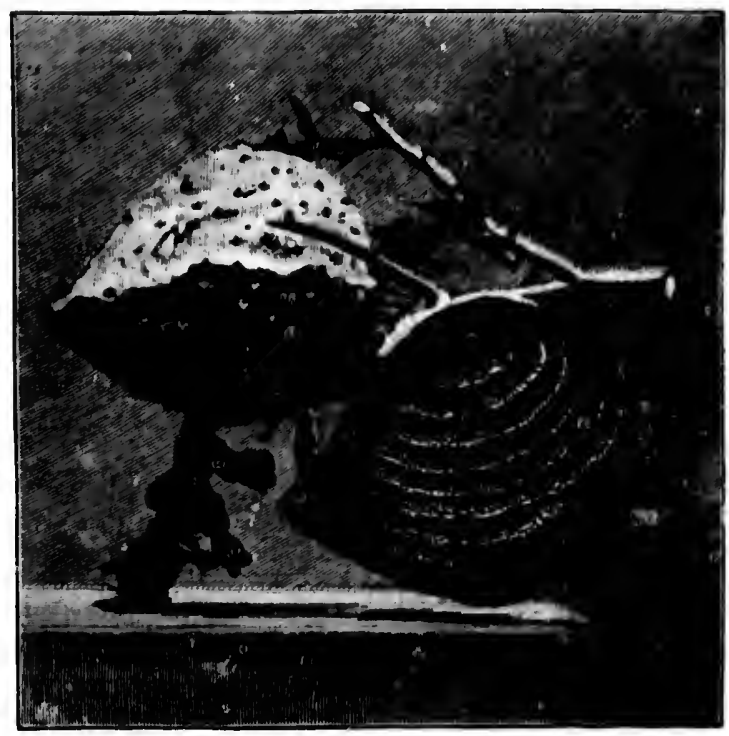

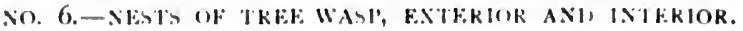

camnot aroid mentioning the fact, that the production of males seems cren to he a direct result of chill and unfavourable conditions. The best food and the higgest eells produce fertile queens; the second hest foud and smaller cells produce workers ; finally, the enfeehlement due to approathing winter 
produces only drones or males. We cannot resist the inference that the male is here the inferior creature. These facts, I regret to say, are also not without parallels elsewhere. Among bees, for instance, the eggs laid by very old, decrepit queens, or by mamed and crippled queens, produce males only; while among tadpoles, if well fed, the majority become female frogs; but if starved, they become preponderantly male. So, too, starsed caterpillars produce only male butterflies, while the well-fed produce females. I know this is the opposite of what most people imagine; but then, science not infrequently finds itself compelled to differ in opinion from most people.

The drones, or males, are thus of as little account in the nest of wasps as in the hive of hees. In both, they only appear for a short time, and for the definite purpose of becoming fathers to the future generations. When they have fulfilled this their solitary function, the hive, or the nest, cares no more about them. The bees, as you know, have a prudent and economical habit of stinging them to death, so ats not to waste good honey on useless mouths through the winter. The wasps act otherwise. They are not going to live through the winter themselies, so they don't take the trosble to execute their brothers: they merely turn the young queens and males loose, and then leate the successful suitors to be killed by the first frost without further consideration.

And now comes the most curious part of all 
this strange, eventful history. We do not love wasps; yet so sad a catastrophe as the end of the nest cannot fail to affect the imagination. As soon ats the young queens and males have quitted the combs, the whole bustling eity, till now so busy, seems to lose heart at once and to realise that it is doomed to speedy extinction. Winter is coming on, when no worker wasp can live. So the community proceeds with one accord to commit commumal suicide. The workers, who till now have tended the young groubs with sisterly care, drag the remaining larve ruthlessly from their cells, as if conscions that they can never rear this last brood, and carry them in their mouths and legs outsicle the nest. There they take them to some distance from the door, and then drop them on the sround to dic, ats if to put them ont of their misery. As for the workers themselves, they return to the nest and starve to death or die of cold ; or else they crawl abont aimlessly outstide in a distracted way till the end overtakes them.

There is something really pathetic in this sudden and meaningless downfall of a whole vast cityful ; something strange and weird in this constantly repeated effort to huild up and people at great community, only to see it fall to pieces hopelessly and helplessly at the first touch of winter. Yet how does it differ, after all, from our human empires, salve in the matter of cluration? We raise them with infinite pains only to see them! fall apart, like Rome or Babylon. 
So, by the time the dead of winter ccmes, both males and workers are cleared off the stage; and universal wasplom is only represented by a few stray fertilised females, who carry the embodied hopes of so many dead and ruined cities.

And now that I have traced the history of the

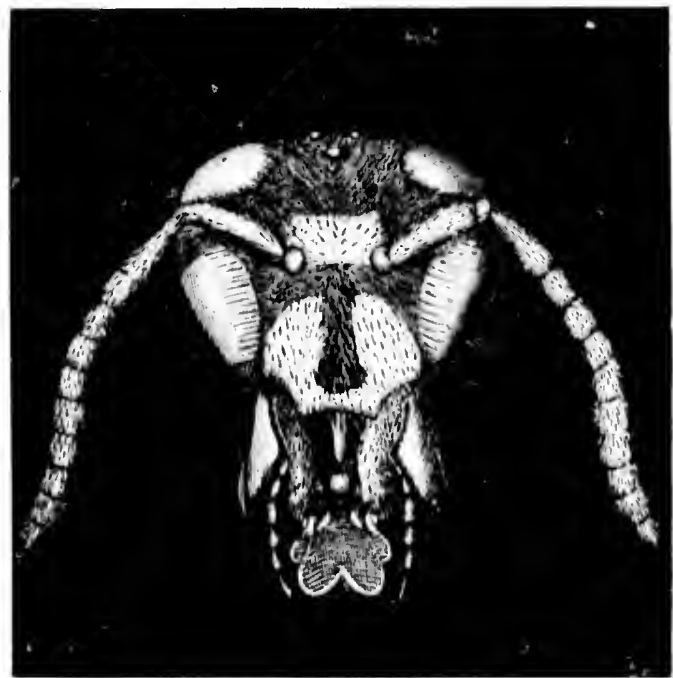

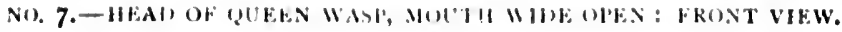

commune from its rise to its fall, I must say a few words in brief detail about the individual wasps which make "lp its memhers.

And first of all as to the wasp's head. You will have gathered from what I have said that the head of the insect is pratetically by far its most impor- 
tant portion. All the work we do with our hands, the wasp does with its complicated month-organs. And the wasp's head is such a wonderful mechanism, that some little study of the accompanying illustrations, thomgh they may not at lirst sight look very attractive, will amply repaly you, I will

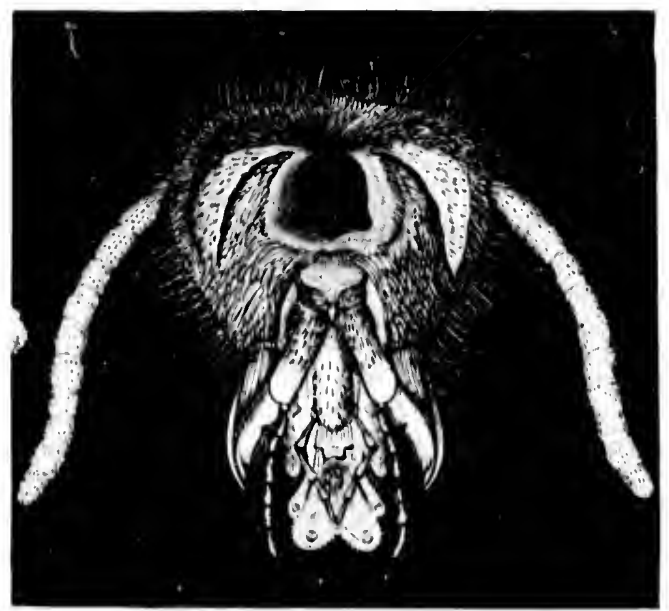

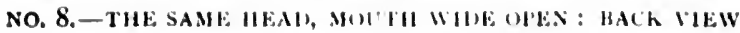
(DECAPITATEI).

try to explain the uses of each part with as little as possithle of scientific technicalitien.

In No. 7 gou get the head of at yueen wasp, seen full face in fromt, with the mouth-organs open. The three little knohs in the centre up ahose are the simple eres or eycetets (ocelli, if you prefer at lattiu word, which sounds much more learned). 


\section{0 \\ Flashlights on Nature}

The large kidney-shaped bodies on either side of the heat (here sien as interrupted by the antenna or fecters) are the eomponind eyes, each of which consists of innmmerable tiny lenses, giving the wasp that possesses them a very acute sense of vision. We do not know exactly what is the difference in use hetween the simple eyes and the

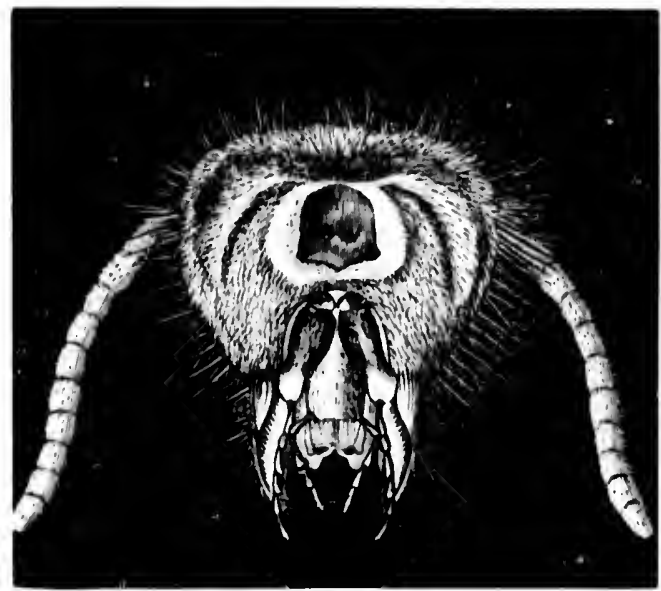

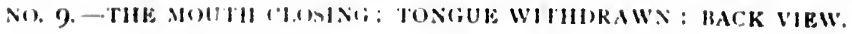

componend ones; hut either sort hats cloubtless its own special part to play in this complex personality. The antentle, or feclers, again, with their many joints and their hall-and-socket hatse, are heautiful and wonderful objects. The varions parts of the mouth are liere sech open : comspiculous among them are the great salw-lilie onter jaws, used for 
scraping wood and manufacturing papes ; the long, narow shield; the broad tongue; and the delicately jointed palps, or finger-like feeders. Notice how some of these organs are suitable for cutting and rasping, while others lend thenselves to the most dainty and delicate manipulation.

No. 8 shows us the sitme leated, decalpitated, and

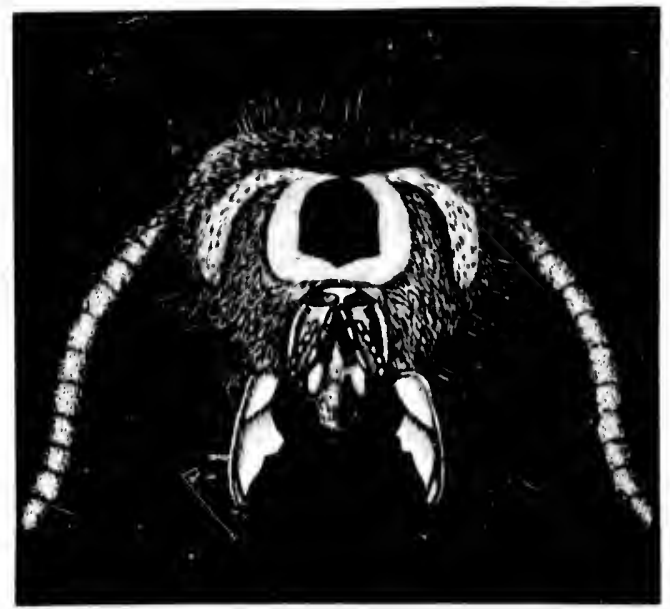

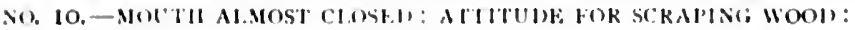
BA'K

reen from behind. The shickd-like space in the rery midelle repuesents the promt of decapitationthe cut neck, if I maly use frankly human language. Below is the hollow on receptack into which all the orgatus eatn be withdratw when nest in use, and packed away like surgieal knives and lansect in ans instroment case. Observe in the secpuel how neatly 
and completely this ean be done: how each has its groove in the marvellous economy of nature.

In No. 9 you see the organs closing (atso at back view), the tonguc having been now drawn in, while the satw-like jaws and the delicate feeling palps ate still exposed and ready for working. No. 8, on the entrary, is the feedings attitude.

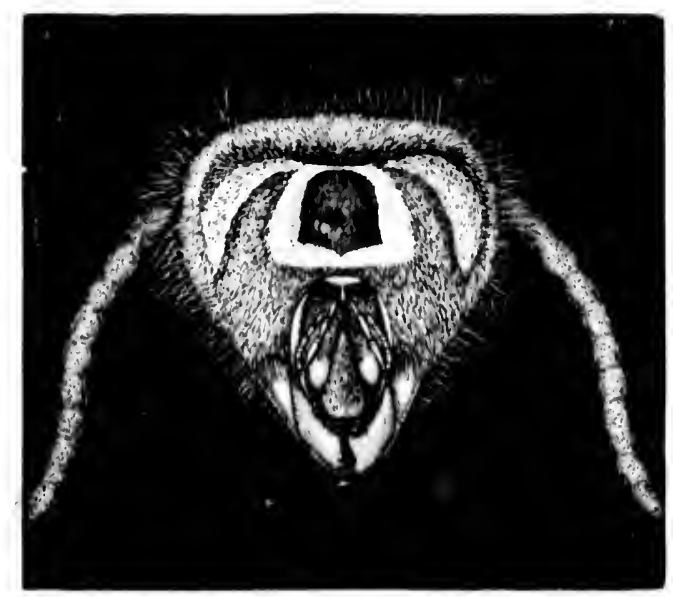

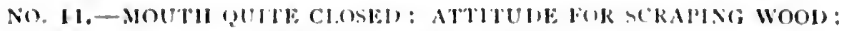
H.NI (H ONE VOFEMENT.

In So. to (another hack view), the palps have been tarned back into their special sronse, and the salw-like jaws are seen free for workings. This is the attitude in which the wasp attacks a patk paling, in oreler to ecraple off wood-fihe for the mannfacture of paper. Here, ats your see, the jaws are open, In No. I I they are closed, at the end 
of a serape. Thene two last attiturlen alle, of eourse, alternate. One shows the jaws openeel, the ofther closed, as they look at the hessimnings and end of each forward and hackward morement. Yon will notice atso that, as ustal, the insect's jaws work sideways, not up and down like those of man and other higher anmals. If ron examine closely this series of wayp's hearls in different postures, you will see how well the various parts are adapted, not only for rasping and mannfacturing paper, but also for the more delicate work of wall and cell buildings.

Almost as interesting as the head are the limes of Masple, of which there are follt, ats in mosst other insects. But they hate this curious peculiarity: the two front wings have at crease down the middle, so that they can he folded up lengthwise, like two segments or rays
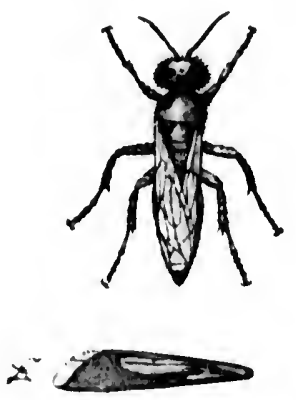

No. 12.- MUREN findele miscis, A

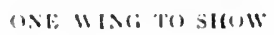
1.11.1)1.18:

of a fan, and thus oecupy only

half the spate on the body that they would oftherwise do. It is this odel deriece that makes the transparent and satury wings no relattively incon-

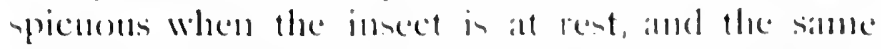
caluse contributes also to the dimplay of the handsome hlack-and-yellow-striped holy. Xo. 12 shows us a queen with ber wing folked: helow is one upper or front wing, folded oser an itself, and then laid across the under wing. No. 1, 3 introduces us 
to a more characteristic feature, common to wasps with the whole bee family.

All these cousins possess by common descent the usual four wings of well-regulated insects. But it so happens that the habits of the race make strong and certain flight more practically important for them than the mere power of aerrial

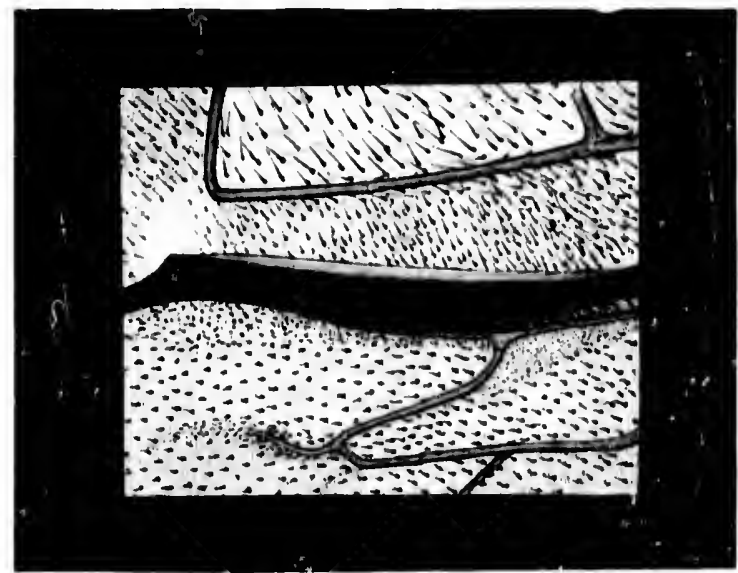

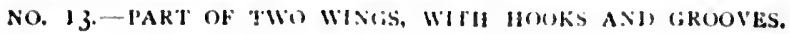

coquetting and pironctting possessed by the far less business-like huttertlies. Your wasp and your bee are women of husiness. They have therefore found it paty them to develop a mechanism by which the two wings on either side can be firmly locked together, so as to act like a single pinion. No. I 3 very well illustrates this admirable plan for fastening the fore and hind wings tegether. 
On top goul sece the batek portion of the front

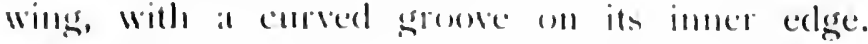
Below, you seet the fromt portion af the hinder wing, with a series of little hooks, microseopice, yet exyuisitely mombled, which eateh intes the sroose on the opposite pertion. Molen thus hosked together, the two wings on the right alt exactly like one. So do the two on the left. But they call be tulllisoked and folded hack on the herly at the will of tire insect. To either sicle of No 13 roul will notice sections of the two wings, which will help you to curclerstand the nature of the mechantism. On the right, the wings are seen hooked together ; on the left, they are callght just in the act of unhooking.

last of all, and most important of all to ordinary humanity, we come to the sting, with its appendange the poison-hats. It is well represented in No. 1 t. The main object of the sting, and its ori-

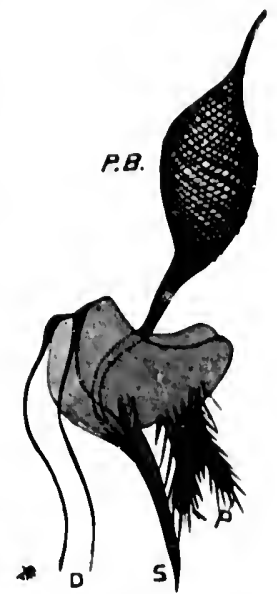

Si. 14. PUSON HAT, SHEATH, DARIS, A.NI) I'AIII. sinal function hy desecent, is that of laying eggss ; it is merely the oripositor. But besides the srooved sheath or eggr-layer (matreel $S$ in the illustration) and the two very sharp lances or clats (marked D) which piere the llesh of the enemy, it is provided with a gland which secretes that most mopleatsant body, formic acid ; and when the watsp has callse 


\section{6}

Flashigights on Nature

to be annoyed, she throws the sting rapidly into the animal that

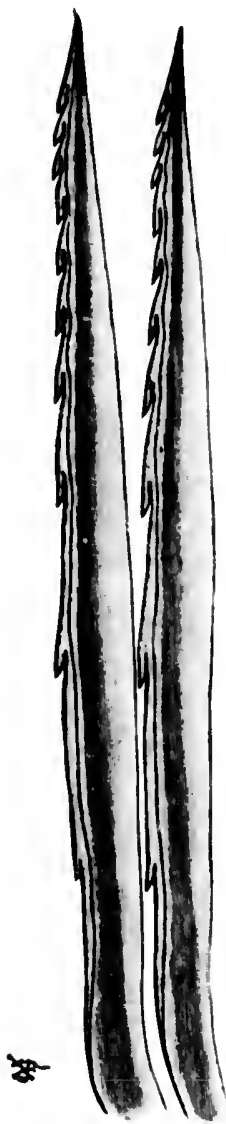

annoys her, and injects the fluid with the formic acid in it. In No. I 5 the darts are shown still more highly magnified. In the queen watsp, the sting is used both for laying eggs and as a weapon of offence ; but in the workers, which cammot lay eggss, it is entirely devoled to the work of fighting.

'rwo other little peculiarities of the wasp, however, deserve a final word of re-

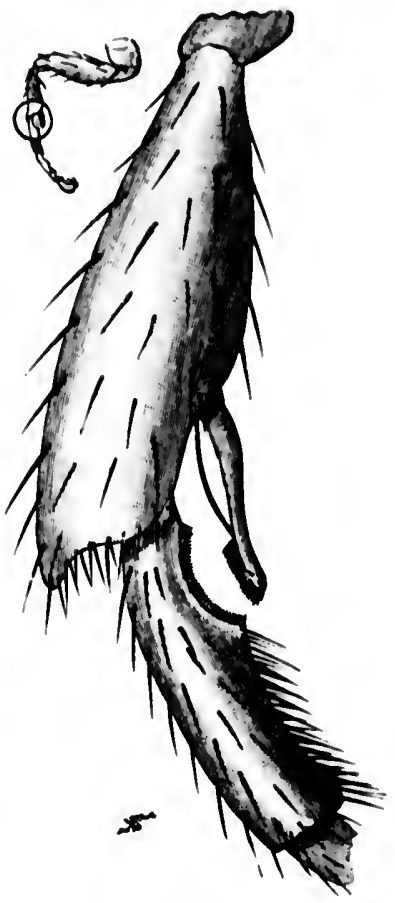

NO, 16. - WASP'S IBRUSH ANI) COMH, HOR CIEANINI; ANTENN.E. cognition. One of these is the elaborate brush-andcomb apparatus or antemne-cleaner, No.15.-DARTSMag. drawn in a very enlarged view in NIFIED 3 OO DIA. METERS.

No. I6. Whatever the sense may be which the antemua serve, we may at least be certain that it is one of great import- 
ance to the insect; and both wasps and bees have therefore elaborate hrushes for keeping these valuable organs clean and neat and in working order. They always remind me of the brushes 1 use myself for cleaning the type in my typewriting machine. The antenna-brush of the watsp is fixed on one of her legs; its precise situation on the leg as a whole is shown in the little upper diagram; its detail and various parts are further enlarged below. To the left is the coarse or lange-tooth comb ; to the right is the brush ; and above the brush, connected with the handle hy an execedingly thin and filmy membrane, is the fine-tooth comb, used for removing rery small imparities. With this the wasp eleans her precious feclers much as you may have seen flies clean their wings when they have fallen in a jam-pot; only the watsp's mechanism is much more beatu-

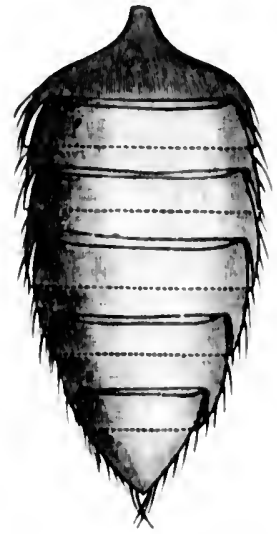

N1) 17.-TUCKS IN TIE SKCOMENTS. tiful and perfect.

Almost equally interesting with the brush and comb are the series of tacks in the watsp's hody or abdomen, delineated in Xo. 17. By means of these extraordinarily thexible rings, each held in place or let loose hy appropriate muscles, the wasp can twist her body round so conveniently that, no matter how carefully and gingerly you hold her, she will manage to sting you. They 
are models of plate-anmour. They work upward, downward, and more or less sideways, so that they enable her to cock her body up or down, right or left, at will, with almost incredible flexibility.

Adequately to tell you all about the wasp, however, would require a very stout volume. I have said enough, I hope, to suggest to you that the wasp's history is quite as interesting as that of her over-lauded relation, the little busy bee. Indeed, 1 suspect it is only the utilitarian instinct of humanity that hats caused so much attention to be paid to the domestic producer of honey, and so relatively little to that free and independent insect, the first parper-maker. 


\section{VIII}

\section{ABIDING CITIES}

THE papery nests of wasps are purely temporary empires: the respine race has "no abiding city here"; each summer sees the populous homes built afresh from the ground; each winter sees them umpeopled and demolished. But with ants, which are builders for time, things are quite otherwise. The communities of those clever and intelligent little creatures are tolerably permanent; they go on from year to year, and generation to generation, often for very long periods together. Lest I weary you unnecessarily by a long preamble, however, I shall present you with views of one such nest at once, outside and inside, in Nos. I and 2 , in order that you may see without clelay the curious method of their detailed construction.

The city whose external lineaments are shown you in the photograph reproduced in No. I is actually situated on St. George's Hill, near Weybridge, just ten feet away from the large Scotch fir whose trunk appears on the right of the illustration. It is only one among many various types of ants' nests built hy different species. From outside, all you can see of it is a confused mass of dry 


\section{0}

\section{Flashlights on Nature}

pine-needles, arranged in a harrow-shaped hill or mound, some eight feet across at the hase, and two

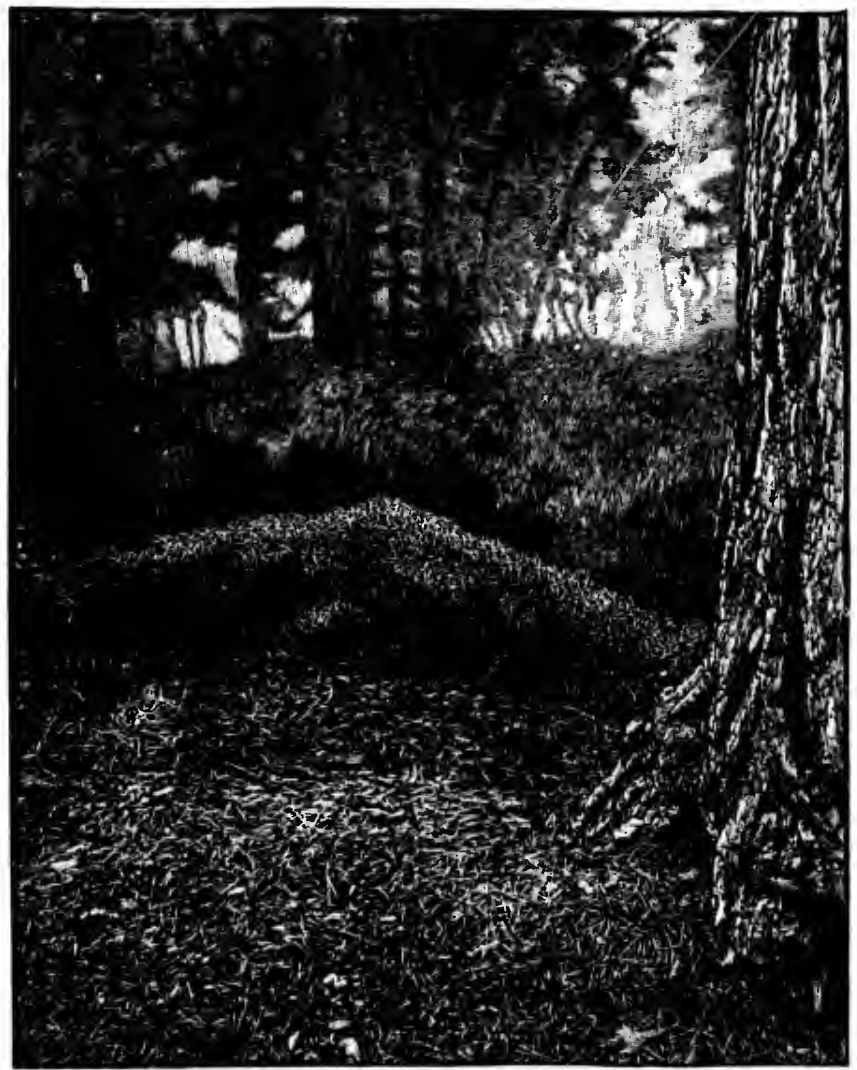

NO, 1.-A WOOD ANTS' NEST, EXTERIOK.

feet high. But that is in reality only the ontwork or top storey of the communal habitation. Beneath 
it lies a second layer, sis inches thick, composed entirely of roots of heather and rootlets of fir-trees, all carefully stripped clean of hatk, and making a dry foundation for the wam hilluck of pine-needles.

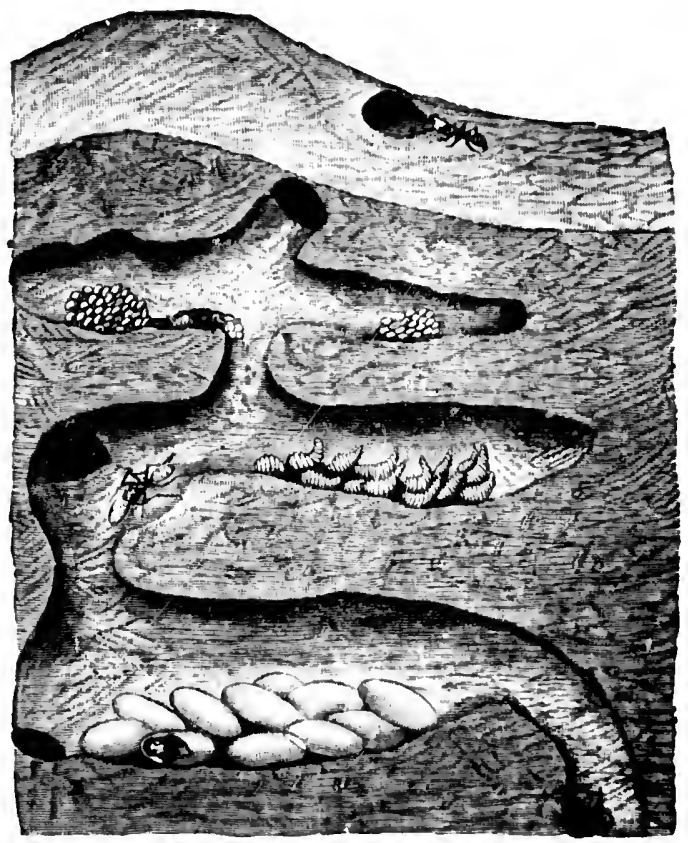

Xo. 2. -A WOOD ANTS' NEST, INTERlOR; Elig, GRUBS, ANI

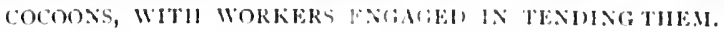

Below this wooly layer, asatin, the sround is tunnelled to an anknown depth by long subterranean salleries, driven right thromsh a stratum of solicl sandstone. These inner gilleries extend not only 
beneath the hillock, but also all round it, for wherever you step the soil treads soft, and gives beneath your foot to a depth of six or eight inches. This illustrative example is a city built by the common Wood Ant. I have had another just like it - an insect London - under observation for three or four years in a copse on a spur of Hind Head, not far from my cottage.

In No. 2 Mr. Enock has represented for us, with his usual skill, a very small section of such a city, "all a-growing and a-blowing,"-ill engaged in the active exercise of its everyday functions. How it came into being, and how it is ruled and peopled, I will tell you a little later on; for the present, I want first to familiarise you with the general course of its domestic economy in practical action. We have here an interior view, with one wall removed, of a tunnel or gallery, which runs through the soft upper portion of the nest, composed of pineneetles; together with a small piece of the outer surface. An ant, which has been out foraging for food, approaches one of the mouths of the nest. Beneath are three sliceessive floors or stages of the tumnel, with excavated chambers, each appropriated to its own particular purpose. In the upper floor of all, we see two groups of minute eggs awaiting their hatching. These are the real eggs, not the much larger things sold as "ants' eggss" for bird food in London, which are really the pupre. Four of the eggs have just arrived at hatching point; therefore, one of the careful nurses who look after them is seen just in the act of bundling them over 
on to stage two, which is the floor here reserved for the nursery of the hatched-out grubs or larva. In this second stage you see a chamber with a group of such grubs, all hungry and greedy, waiting for their nurses to bring them food from outside the household. Observe the obvious expectancy of their attitude, with heads held up, like that of small birds clamouring eagerly for food when their mother approaches them with a worm or a caterpillar. After feeding for some time in this legless, grubbish condition, the larva turns into a pupa, and encloses itself in a cocoon. One larva has just completed this happy transformation, and a watehful nurse ant is therefore at this moment engaged in carrying it tenderly a stage lower down to the floor reserved for the chrysalis condition. On the third floor, below, you see a group of pupa lying by in the dark, and awaiting their development. The wall of one cocoon has here been removed, and within you may catch a glimpse of the imprisoned grub, now recently transformed into the adult ant pattern. Of course, the nest contains many hundreds of such tumnelled galleries, all teeming with life, and all made up of several distinct chambers.

Now, how does such a nest begin to be? Well, it starts from a queen, or perfect female, who sets out with a few others to form a colony. This colony soon grows, but it is rather a republic than an Amazon kingdom, like the hive of hees or the nest of wasps. It is composed of several perfect females (instead of one queen), numerous imperfect females or workers, and a few males, who, as 
is usual among social insects, are very unimportant and unconsidered creatures. The males and females are winged when they first emerge from their cocoons, and they use their wings for their marriage flight, which is a recognised institution among all insect socialists. But as soon as the perfect females have been safely wedded, their wings drop off; or, in cases where they do not fall of themselves, the insects themselves wriggle and pull them off with their legs in the most comic fashion. I have sometimes seen a dinnertable in Jamaica covered by a sudden irruption of female winged ants of tropical species, which insisted on immolating themseives in the soup and the wine (to the advantage of neither party), while others blackened the table-cloth, and devoted themselves to getting rid of their wings with unpleasant gyrations. As for the males, they are of no further use to the community, so they die at once. But the mass of the larve develop into imperfect females or workers, which are always wingless from the very first, and it is these that form the ordinary ants of the everyday observer. In many kinds there are also two types of neuters: the one type, workers proper, have rather large heads and moderate jaws -they are the foragers and builders of the community; the other type, soldiers, have still bigger heads and very powerful jaws-it is their task to fight in defence of their native city. Other differences of less importance will come out in the course of our subsequent explanation.

The winged ants have large and many-faceted 
compound eyes, to aid them in their flight abroad; and they have also single eyelets or ocelli, as in the case of the wasp, which seem to be useful to them in finding the way orer large areas, as the compound eyes are probably clesigned for nearer and minuter vision. But the workers have always the true eyes small, and often rudimentary; while the eyelets or ocelli are mostly wanting. To put it plainly, they are almost blind. There can be very little doubt that their principal organ of sense resides in the antenna, or feelers, which are probably used in part for smelling. Whatever may be the perceptive function which these curious appendages. subserve, however, nobody who has watched ants closely ever cloubts that they are also used as a means of intercommunication, almost analogous to human language. Whenever two ants of the same nest meet, they stop and parley with one another by waving and crossing their antennae; so obrious is it, that the information thus conveyed makes one ant follow another towards a source of food, or other object of interest, which the first ant has discovered, that the process is universally described by ant observers as "talking."

In No. 3 we get an illustration of two workers belonging to an English species known as the Warrior Ant, from its predatory habits, engaged in just such a profound confab together. They are meditating war, and discussing a plan of campaign with one another; for the Warrior Ant is a slave-making species. It is a large red kind, and it 
makes raids against nests of the small yellow Turf Ant, a mild and docile race, large numbers of which it carrie; off to act as servants. But it does not-steal fully-grown Turf Ants; their habits are formed, and they would be useless for such a purpose. What the Warrior Ant wants is raw material which can be turned into thoroughly well-trained servants. So it merely kills the adult ants which strive to oppose its aggression, and contents itself

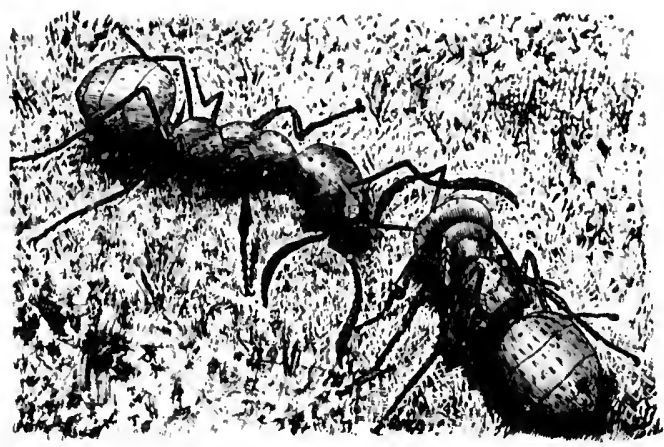

No. 3-DA Conversation: "I.ET"S Go SLAYt-HUNTING!"

with trundling home to its own nest the larve and pupae of the Turf Ants which it has plit to flight and vanquished. In process of time, these grubs and cocoons produce full-grown yellow workers, which, having never known freedom, can be taught by the Warrior Ants to act as nurses and housemaids, exactly as if they were living in their own proper city. I once silw in a garden in Algiers a great pitched battle going on between slave-makers 
and the family of the future slaves, in which the ground was strewn with the corpses of the vanquished. Not till the nest of the smaller ants was almost exterminated did they retire from the unequal contest, and allow the proud invader to carry off their hrothers and sisters in their cocoons, asteep and unconscious.

The two ants figured in No. 3 are deliberating on the chances of such a cocoon-lifting expedition. The one to the right has heen hunting for honey up the stems of retches, and has fallen in by the way with a small nest of Turf Ants. Returning post-haste to her own home, hig with this exciting intelligence, she encounters a comrade, to whom she communicates, in antenna language, her belief that the Turf Ants she has discovered are not very numerous, and her conviction that they would fall an easy p ey to a well-organised party of Warrior raiders. The two friends cross their antennae as they talk, wave them mysteriously about, and evidently succeed in conveying their respective views on the situation to one another. After a short delay, both return, all asog, to the nest together, and rouse the guard with intelligence of plenty of pupa ready to be plundered. At once the city hums, alive with bustle and preparation. Workers run to and fro and communicate orders from headquarters to one another. "There's a hig slarehunt on ; sister-fighter so-and-so has just brought news of a city of Turfites, quite near, and unprotected. The doors are open, and she noticed as she passed that the sentries looked most lax and 
indifferent. The whole place has apparently been demoralised by a recent marriage flight. Everyhody in our nest is going to the war. Come along and help us !"

Forthwith they sally out, and make for the city of the despised yellow Turfites. They fall upon it anexpectedly, and kill the onter sentries. Then the battle hegins in earnest. Hall the lurfites rush out in battle array, and, banding themselves together, to make up for their individual small size, fall fiercely upon this or that isolated Warrior. Occasionally, by dint of mere numbers, they heat off the invader with heary loss; but much more often, the large and strong-jawed Warriors win the day, and destroy to a rorker the opposing forces. They crush their adversaries' heads with their vicelike mandibles. Meanwhile, within the nest, the other half of the worker's - the division told off as special nurses - are otherwise employed in defending and protecting the rising gencration. At the first alarm, at the first watchword passed with waving antennic through the nest, "A Warrior host is attacking us !" they hurry to the chambers where the cocoons are stored, and bear them off in their mouths into the recesses of the nest, the lowest and most inaccessible of all the chambers. When at last the day is lost, the Warriors break in and steal all the pupe they can lay their jaws upon; hut many survive in the long, dark tumnels, with a few devoted workers still left to tend and teach them.

No. + shows us the final stage in such a slave- 
hunt. The big red Warriors have wons the little yellow 'Turfites bave been repulsed and defeated with great slaugliter. The victors are at present engaged in carrying captured cocoons to their own nests; there the pupae will hatch out shortly into willing slaves, and, never having known any other condition, will take it for granted that the natural post for small yellow ants is to clean and forage and catch food for his red ones.

Our own Warrior Ants are sare-holders which

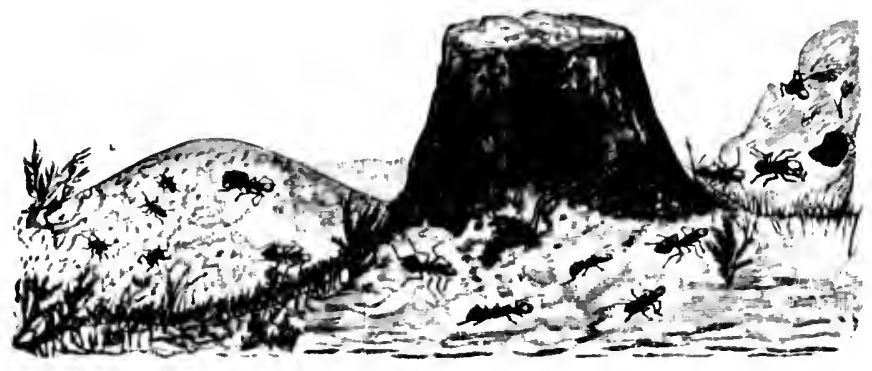

NO, 4.-A SIAIE-HCNT; CONGUERORS CARRIING OFF TIE. COCOONS OF THE IES EMY.

still retain some power of working and acting for themselves; but there are other species in which the "peculiar institution" has produced its usual degrading result by rendering the slave-owner incapable and degenerate, a mere fighting do-nothing. Among the Amazon ants, which are very confirmed slave-makers, Sir John Lubbock found that a great lady, left alone without slaves, in the presence of food, did not even know how to feed hervelf; she was positively starving to death in the midst of 
plenty. Then Sir John provided her with a single slave; instantly, the inclustrious little creature set to work to clean and arrange her mistress, and to offer her food. This is a striking illustration of the moral truth that slavery is at least as demoralising for the master as for his servant.

No. 5 introduces us to a passing phase in a combat of ants-a life-and-cleath conflict between

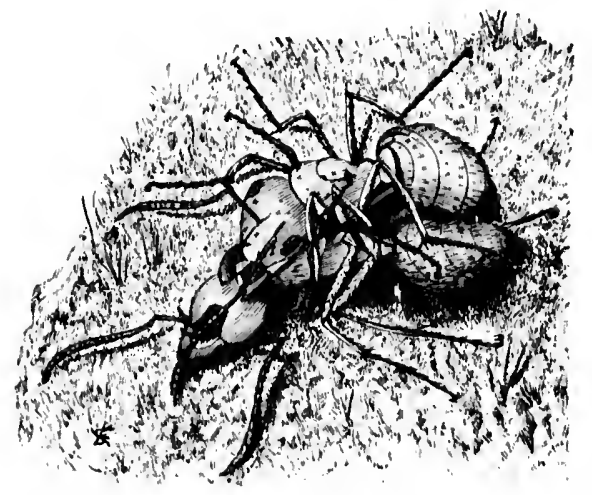

NO, 5. PAYTA OFF OLD SCORES: A L.LEAND-DEATH CONFLICT. two single antagonists. Ants, incleed, are desperate fighters; the workers and perfect females have sometimes stings, like the bees and wasps ; hut in most species they fight by biting with their jaws, which are moulded into strong and rice-like nippers or pincers. Moreover, they have a gland which secretes the same poisonous material as that contained in the renom-bays of the sting annong wasps and bees; and after the ant has macle a hole with her jaw in her enemy's armour, she injects into it a little of this painful irritating acid, which kills small insects. During a battle, ants are all most reckless of their own lives; incleed, no ant seems ever to consider herself by compari- 
son with the interests of the community at large. The individual exists for the estate alone, and sacrifices her life and happiness, antomatically as it were, on behalf of her city.

In No.6 we see an illustration of the great muscular strength possessed by ants, especially in their gripping jaws or mandibles. Here, two comrades have got hold of a dead and rigid prey, which they are striving to carry off by main force to the nest; for ants are omnivorous. 'They feed ofi whatever turus up handy; all is fish that comes to their netthey seem almost indifferent whether what they dine off is honey or honeyclew, a worm or a beetle, a dead bird or a departed lizard. A few worker's willseize whatever edible object they happen to find, and combine

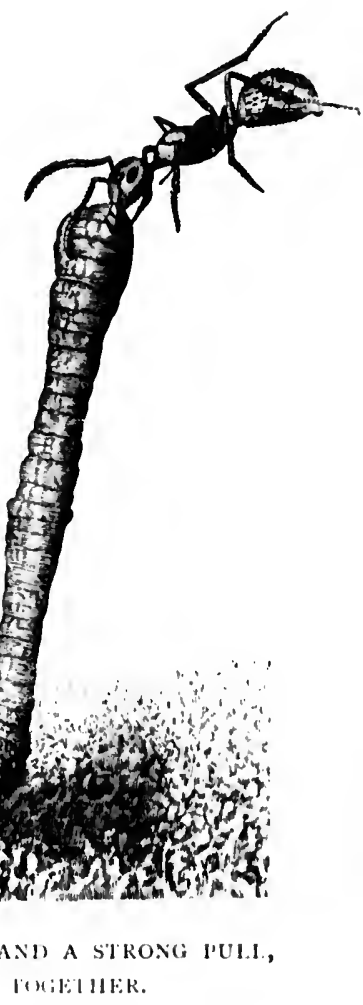
to drag it

away, by pushing and pullins, to the underground chambers. In this particular case the two ants began by hatuling together; but the lower one, giving one good tug with her jaws, has succeeded 
in raising the whole carcass aloft, and hoisting up her astonished neighbour into the air on top of it. It is impossible to watch a nest of ants at work for any length of time without heing the spectator of many such comic little episorles.

I implied above that ants are very fond of honey. But plants by no means desire their attentions; because, being creeping creatures, guided mainly by the sense of smell, they crawl up the stems of one species after another, indiscriminately, and so do no good in setting the seeds of any particular kind of flower. 'To baffle them, accordingly, many plants cover their stems with downward-pointing hairs, which prove to the ants as impenetrable an obstacle as tropical jungles to the human explorer; while other sorts set various traps like lobsterpots on their stalks, to cateh and imprison the unwelcome visitors. But the wild vetehes have a still more curious and instructive habit, shared by not a few other ingenious plants. They buy off the intruders by an organised system of blackmail. Below the flowers intended for fertilisation by fiying insects, which flit straight from one blossom to another of the same kind, the vetches put some arrow-shaped suards or stipules, so arranged like barriers on the stem that a prying ant cannot easily creep past them. In the centre of each stipule, however, the plant produces a little black gland, which secretes honey. This honey is a bribe to the marauding ant; the vetch puts it there in order that the insect, finding its progress toward the flower blocked, may just stop en route 
and sip this pittance of nectar, leaving the richer and more valuable stock of honey in tle actual blossom to be rifled by the bees which are the honoured guests and allies of the retches. Nature is all full of such quaint plots and comnterplots. One example occurs in a South Anerican tree, so very remarkable that I camnot pass it by even in this hasty notice.

A certain ant, very common in Brazil, has the habit of cutting large round pieces out of the leares of trees, which it then conveys to its nest for the purpose of growing fungi upon them-in human language, making tiny mushroom-leds. Now, this habit is naturally obnoxious to the trees, which produce the leaves for their own advantage, not for the sake of leaf-cutting ants which hack and rob them. To guard against the hurglarious leafcutters, accordingly, one clever South American acacia has hit upon an excellent plan of clefence. It produces curious hollow thorns; while each leaflet has a gland at its base which secretes honey. Into these hollow thorns, colonies of a small and harmless ant migrate, and take up their abode there. They live off the boney at the base of the leaflets. They thus acquire a rested interest in the acacia tree, which is their home and territory; and whenever the leaf-cutting ants attack the acacia, the little occupants of the thorms and owners of the honey-chambers pour out upon them in their thousands, and compel the invaders to beat a hasty retreat with heary losses. Thus the cunning tree supplies its insect body-guard with board and 
locksing in return for efficient protection against the dreaded onslanght of the common enemy.

And now that I have sneceederl, I hope, in interesting you a little in the habits of ants, I am going to tell you a few facts about their structure. 'That is my dodyiness, you see; I knew if I began by giving you details of legs and hody and segments, you would vote tha whole thing dry; hut

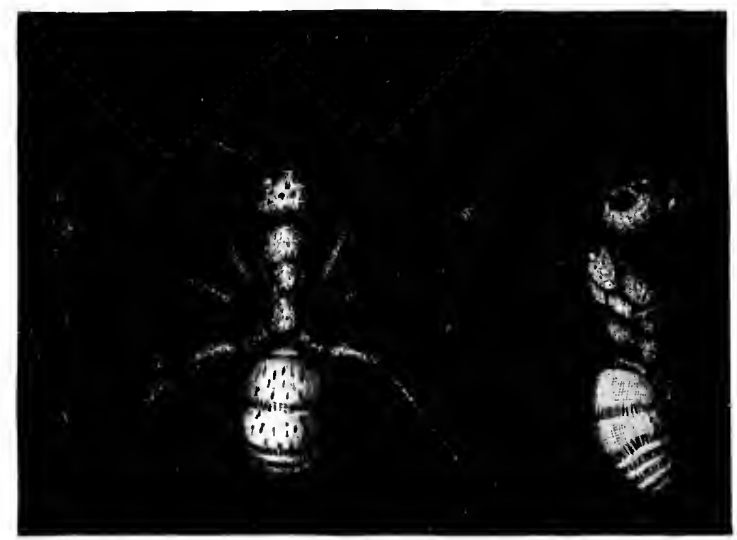

NO. 7.-THE GARIEN ANT-PORTRAIT OF A WORKER.

now that you mucterstand what sort of objects the ant wants to attain, you may be content to examine the orsans she attains them with.

In No, 7 you have a portrait of the common Garden Ant of England, one of the most interesting creatures in the world to watch in action. This is a worker specinen; therefore, it has a very big head, with very powerful jaws; and when 
you remember that ants work for the most part with the head only, you will understand why that portion needs to be the most muscular and powerful part of the body. A lobster has two very strong elaws in front, hecallse those are his fighting and prey-catching organs; the ant's jaws just answer in function to the lobster's claws, and to our hands and arms, and, therefore, they are correspondingly bis and muscular. Male and female ants do not have to dig tumnels, to build up chambers, to drag heary weights back to the nest; therefore, they have smaller heads and bigger eyes; they are adapted only for flying and for producing the younger seneration. The middle segments of the body, on the contrary, are large and powerful in the males and females, because they have to work the wings; while in the workers they are smaller, especially in one segment, because the workers are wingless. The legs, however, are fairly strong, since they need to pull and to supply a firm footings when the ant is tugging hard at some heary object. But between the part of the body which forms the attachment for the six legs and the aldomen, or "tail," there is a single characteristic segment, or stalk, very thin and stender, which bears a sort of scalle, peculiar to the ant family. The side view, with the lesse remored, emables you to note how admirably. the ant is atdapted for turning in almost any dircetion, and explains that extraordinary flexibility of hody which you must have noticed whenever you have watched 
a troop of ants trying to drag a clead inscet over a gravel path, and sumomonting all obstacles with clumsy ingenuity. Ants, in short, are built for navvies; they are insect engineers, and they have acquired a form exactly adapted to their peculiar luabits.

But why are the worker ants so nearly blind? That must surely be a divalvantige to them.

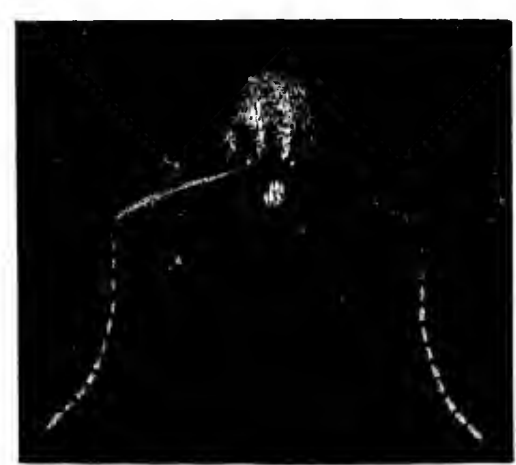

Not a lit of it. Ant: work mainly in dark undersround passages, where the sense of sight would be of little use; and, moreover, like all hunting animals, they find smell more important as an indicator of

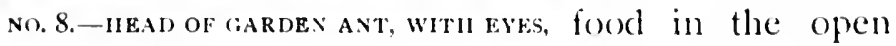
ANTENNA, JAWS, ANU FFELERS.

than vision. 'The homind does not look for the fox he suiffs and seents him. Now, whenever any sense is relatively unimportant, an economy maly be effected by smppressing or curtailing it ; the material that would otherwise go to making and repairing its organ is more profitably employed on some better work elsewhere. Ants are obviously descendants of flying ancestors, none of which were workers; and the flying males and females possess to this day the organs of sight 
necessary for their habits. But in the class of workers it has been found more useful, on the whole, to concentrate attention on snell and on strength of jaw than on sight and flight: the important point is that the worker ant should be able to find scattered foodstufis, and should be strong enough to pull them back to the city. So in No. 8 you set a front riew of the head of the common Garden Ant ; and you will see for yourself that its eyes, when compared with the nume-

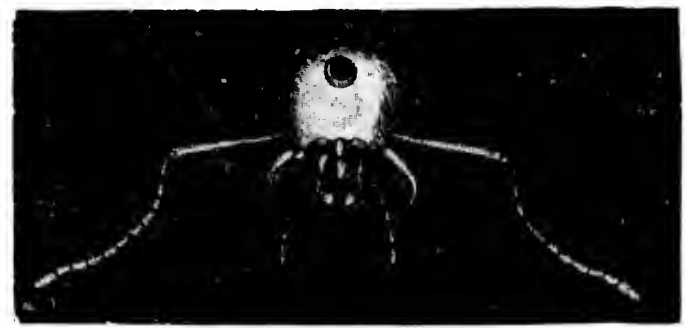

NO. 9. - BACK VIEW OF HEAD, WITH JAWS OPEN, ANU ORGiNS EXPANOFE.

rous eyelets and large eomponud organs of the wasp, are relatively imperfect; while its antemne are large and fully dereloped appendages. They turn in a hoantiful ball-and-socket joint, which enables them to more freely in erery direction. Now, these antennae quite clearly serve several most important uses in ant life. 'They are the organs of speech in ants, ats well ats the organs of a special sense; just as, with ounselies, the mouth is used equally for tasting and talking. 
Darwin said with justice, indeed, that, considering its size, the brain of an ant wats perhaps the most marvellous piece of matter in the whole minerse; and its raw material of intelligence is apparently supplied it most of all through the mysterious antennae.

No, 9 is a back view of the same head, with the varions jaws and monthpieces expanded. It shows very well the complicated nature of the tongue, the palps, the shield, and so forth, and also the powerful nipping jaws, with their closely serrated and tooth-like edge-these last being the weapons used in battle and in repelling the attacks of large enemies. It also excellently exhibits the complex arrangement of the beautiful jointed antenna. The black spot in the centre of the head above is the cut neck, or esophagus. I advise you to look closely at the mouth-organs in this microscopic drawing, and to compare them with the correspondings parts in the wasp, illustrated by Mr. Enock in the last chapter.

Considering how important the antennie are, it will not surprise you to learn that the clean little ants have a special instrument, like the bees and wasps, for keeping these useful outgrowths in proper order. The singular brush-and-comb with which they clean them is shown in No. Io, together with a smaller representation of the entire leg on which it exists, so as to emable you to see where the ant carries it. Ants, indeed, are as fond of washing themselves as eats; and when any accident happens to one, stuch as getting 
smeared with honey, you will see the little creature carefully getting rid of the foreign body with her hairy legs, and paying particular attention to her precions antennae. The mere existence of such develoved brushers is sufficient to

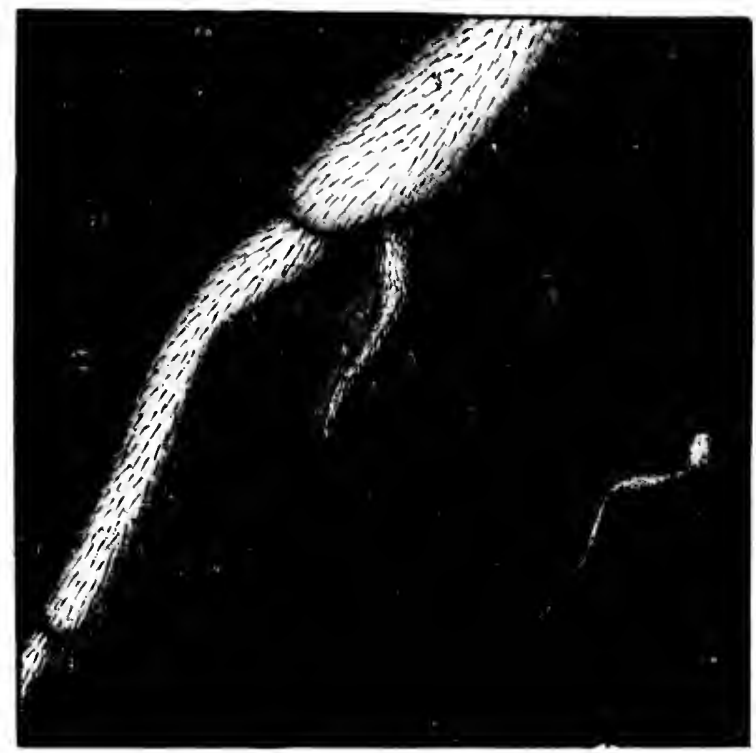

No, 10.-THE ANT'S BRUSH-AND-COMB, FOR CLEANING TIII. ANTEXN.T.

prove the immense importance of the orgatms they clean to the bee-and-int order.

'The life-history of an ant falls inte four periods or anges: the egss, the situh, the prupat, and the perfect insect. The essis, which atre very timy, 
are white or yellowish, and somewhat elongated; those observed by Sir John Lubbock, the great authority on ants, have taken a month or six weeks to hatch. The larve, like the young of hees and wasps, are white, legless grubs, narrow towards the head. The picture in No. 2, indeed, only imperfectly suggests the constant care with which they are tencled by the nurses in early life; for they are carried about from room to room at different times, apparently to secure the exactly proper degree of warmth or moisture; and they are also often assorted in a sliding-scale of ages. "It is sometimes very curious to see them in my nests," says Sir John Lubbock, "arranged in groups according to size, so that they remind one of a school clivided into five or six classes." After a longer or shorter period of grubhood, which differs in length in different species, they turn into pupie, either in a cocoon or naked. It takes the insects three or four weeks, in the pupa form, to develop into fullgrown ants; and even when they have finished, they are as belpless as babies, and could not escape from the cocoon but for the kind offices of the worker attendants. "It is pretty to see the older ants helping them to extricate themselves, carefully unfolding the legs and smoothing out the wings" of the males and females, "with truly feminine tenderness and delicacy." This utter helplessiness of the young ant is very interesting for comparison with the case of man; for it is now known that nothing conduces to 
the funal intellectual and moral supremacy of a race so much at the need for tending and carefully guarding the young; the more complete the dependence of the offspring upon their elders, the liner and hisher the ultimate development.

Ants are likewise great domesticaters of varions other animals; indeed, as I have said before, they keep many more kinds of flocks and herds in condinenent than we ourselves do. There is is fummy little pallid creature, ealled Beckia, an active, bustling small thins, remotely resemblins a minute earwis-lanva, which runs in and ont anongs the ants in sreat numbers, keeping its antennae always in a state of perpetulul vibrattion. The nests also harbour a queer, armourplated white wood-louse, whose longs Latin-German name I mercifully spare you ; and this strange beast toddles about quite familiarly among the ants in the salleries. Both kinds must have been developed in ants' nests from darlier animals; and both are hlind, from long residence in the dark undersonomed tumnels which they never yuit; their lishtness of colom and the disappearance of their eyes tend alike to show that they and their ancestors have resided for countless ages in the homes of the ants. Fet $n 0$ ant erer seems to take the slightest notice of them. Still, there they are, and the ants tolerate their presence; while an manthorised interloper, as Sir John Lubbock remarks, would at once be set upon and killed. The accomplished entomologist in question suggests that they may perhaps act ats 
scavengers, like the wild dogss of Constantinople or the turkey-buzzard vultures of the West Indies and South America. I hare sometimes almost been inclined to strspect, myself, that they may be kept as totems, much as human savarges domesticate one of their revered ancestral animals ats an object of worship.

In other catses the relation between the ants and their domesticalted animals is more distinctly economical. For instance, there is a blind beetle -most ant-cattle are blind from long residence in the tunnels - which hats actually host the power of feeding itself; but the ants feed it with their own food, and then caress it with their antenne, apparently in order to malic it sive forth some pleasant secretion. This secretion seems to be poured out by a tuft of hairs at the hase of the beetle's hatrd wing-cases; these tufts of hair the ants take into their mouths and lick all over with the greatest relish. Some ant tribes even strike up an alliance with other ants of a different species, whose nest they frequent and whom they follow in all their wanderings. Thus, there is a very tiny yellow ant, known as Stenamma, which takes up its abode in the galleries of the much larger Horse Ants and Field Ants. When these big friends change their quarters to a new nest, as frequently happens, the tiny Stenammats accompany them, "running about among them," says Sir John Lubbock, "and between their legs, tapping them inquisitively with their antenna, and even sometimes climbing on to their backs, as 
if for a ride, while the lange ants seem to take little notice of them. 'They almost seem to be the dogs, or perhaps the cats, of the ants." In yet another case, a wee parasitic kind makes its own small tumnels in and ont among those of a much reger species, members of which cannot get at the petty robhers, because they are themselves too hig to enter the minute galleries. The depredators are, therefore, quite safe, and make incursions into the nests of their higger victims, whose larve they carry off and derour-" as if we had small dwarfs, ahout eighteen inches long, harbouring in the walls of our houses, and every now and then carrying off some of our children into their horrid dens."

When once one hegins upon these fascinating insects, the difficulty is to know when to stop. But I have said enough, I hope, to suggest to you the extraordinary interest of the study of ant life. Even if observed in the most amateurish way, it affords one opportunities for endless amusing glimpses into the politics of a community full of comic episodes and tragic denouements. 


\section{IX}

\section{A FROZEN WORLD}

7 HE pond in the valley is a world by itself. So far as its inhahitants are concerned, indeed, it is the whole of the world. For a pond without an outlet is like an oceanic island; it is a system, a microcosm, a tiny society apart, shut off by impassable barriers from all else around it. As the sea severs Fiji or St. Helena from the great land-surface of the eontinents, so, and just at truly, the fields about this pond sever it from all other inhabited waters. The snails and roach and beetles that dwell in it know of no other world; to them, the pond is all ; the shore that bounds it is the world's end ; their own little patch of stagnant water is the miniverse.

A pond which empties itself into a river by means of a stream or brook is not quite so isolated. It hats points of contact with the outer earth: it resembles rather a peninsula than an island: it is the analogne of spain or Greece, not of Hawaii or Madeira. And you will see how important this distinction is if you remember that trout and stickleback and stone-loach and 
fresh-water mussels can ascend the river into the brook, and pass by the brook into the pond, which has thus a clirect line of communication with all waters elsewhere, inchuding even the great oceans. But the pond without an outlet cannot thus be peopled. Whatever inhabitants it possesses have come to it much more by pure chance. They are not able to walk overland from one pond to another; they must be brought there somehow, by insignificant accidents. Renarded in this light, the original peopling of every pond in England is a problem in itself - a problem analogous in its own petty way to the problem of the peopling of oceanic islands.

That great and accomplished and ingenious naturalist, Mr. Alfred Russel Wallace, working in part upon lines long since laid down by Darwin, has shown us in detail how oceanic islands have in each ease come to be peopled. He has shown us how they never contain any large indigenous land animals belonging to the sreat sroup of mammals-any deer or elephants or pigs or horses; becatuse mammals, being born alive, cannot, of course, be transported in the egg, and because the adult beasts could seldom be carried across great stretches of ocean by acciclent without perishings on the way of cold, hunger, or drowning. One can hardly imassine an antelope or a buffalo conveyed safely over sea by natural causes from Africa to the Cape Verdes, or from America to the Bermudas. As a matter of fact, therefore, the natural population 
of oceanic islands (for I need hardly saly I set aside mere human agencies) consists almost entirely of hirds blown across from the nearest continent, and their descendants; of reptiles, whose small eggs can be transported in logs of wood or broken trees by ocean currents; of snails and insects, whose still tinier spawn can he conveyed for long distances by a thousand chances; and of such trees, herbs, or ferns as have very light seeds or spores, easily whirled by storms (like thistledown), or else nuts or hard fruits which may be wafted by sea-streams without clamage to the embryo. For the most part, also, the plants and animals of occanic istands resemble more or less closely (with locally induced differences) those of the nearest continent, or those of the land from which the prevailing winds blow towalds them, or those of the country whence currents run most direct to the particular island. They are waifs and strays, stranded there by accident, and often giving rise in process of time to special local varieties or species.

Now, it is much the same with isolated ponds. They acquire their first inhabitants by a serjes of small aceidents. Perbaps some water-hird from a neighbouring lake or river alights on the sticky mud of the bank, and brings casually on his webbed feet a few clinging egss of dace or chub, a few fragments of the spawn of pond-snails or water-beetles. Paddling about on the brink, he rubs these off by mere chance on the inud, where they hatch in time into the first colonists of the 
new water-world. Perhaps, again, a heron drops a half-eaten fish into the water-a fish which is dead itself, hut hats adhering to its scales or gills a few small fresh-water crustaceans and mollusks. Perhaps a flood brings a minnow or two and a weed or two from a neighbouring stream; perhaps a wandering frog trails a seed on his feet from one pool to another. $13 y$ a series of such accidents, each trivial in itself, an isolated pond acquires its inhahitants; and you will therefore often find two ponds close beside one another (but not connected by a stream), the plants and animals of which are nevertheless quite different.

Now, the pond in summer is one things the pond in winter is quite another. For just reflect what winter means to this little, isolated, self-eontained community ! The surfice freezes over, and life in the minic lake is all but suspended. Not an animal in it can rise to the top to breathe; not a particle of fresh oxygen can penetrate to the bottom. Under such circumstances, when you come to think of it, you might almost suppose life in the pond must eease altegether. But nature know's better. With her infinite eleverness, her infinite varicty of resource, of aclaptation to circumstances, she has invented a series of extraordinary devices for allowing all the plants and animals of a pond to retire in late autumn to its unfrozen depths, and there live a dormant existence till summer comes again. Taking them in the mass, we may saly that the population sink down to the bottom in November or December, 
and surge up again in spring, though in most varied fashions.

Consider, once more, the curions set of circumstances which renders this singular plan feasible. Water freezes at 32 degrees Fahrenheit. For the most part, under nomal conditions, the water at the top of the pond is the warmest, and that at the bottom colclest; for the hot water, being expanded and lighter, rises to the surface, while the cold water, being contracted and heavier, sinks to the depths. If this relation remained unchanged throughout, when winter came, the coldest water would gradually congeal at the bottom of the pool: and so in time the whole pond wonld freese solicl. In that case, life in it wonld obviously be as impossible as in the ice of the frozen pole or in the slaciers of the Alps. But by at singular variation, just before water freemes, it begins to expand agatin, so that ice is lighter than water. Thus the ice as it forms rises to the surface, and leaves at the hottom a layer of slightly warmer water, some four or five degrees above freezing point. It is usual to point this fact ont as a beantiful instance of special provision on the part of nature for the plants and animals which live in the ponds; but to do so, I think, is to go just a step beyond our evidence. Nature cloes not fit all places alike for the development of life; she does not fit the desert, for example, nor the interior of glaciers or frozen oceans, nor, for the matter of that, the rocks of the earth's mass; nor does she try to fit living beings for such 
impossible situations. All we are really entitled to say is this-that the conditions for life do ocenr in ponds, owing to this habit of water, and that therefore special plants and animals have been adapted by nature to fulfil them.

The devices by which such plants and animals get over the difficulties of the situation, however, are sufficiently remarkable to satisfy the most exacting. Recollect that for some weeks together the entire pond maly be frozen over, and that during that dreary time all animal or vegetable life at its surface must be inevitahly destroyed. For hardly a plant or an animal can survive the actual freezing of its tissues. Nevertheless, as soon as winter sets in, the creatures which inhahit the pond feel the cold coming, and hegin to govern themselves accordingly. A few, which are amplibious, migrate, it is true, to more comfortable quarters. Among these are the smaller newts or efts, which crawl ashore, and take refuge from the frost in cramies of rocks or walls, or in cool damp cellars. Most of the inhahitants of the pool, however, remain, and retire for warmth and safety to the depths. Even the amphihious frogs themselves, which have hopped ashore on their stont legs in spring, when they first emerged from their tadpole condition, now return for security to their native pond, bury themselves comfortably in the mud in the deptis, and sleep in social chusters through the frozen season. They are not long enough and lithe enough to creep into crannies above ground like the newts; and with their soft smooth skins 
and unprotected bodies they would amost inevitably be frozen to death if they remained in the open. On the bottom of the pond, however, they huddle close and keep one another warm, so that portions of the mud in the centre of the pool consist almost of a living mass of frogs and other drowsy animals.

Some of the larger pond-dwellers thus hibernate in their own persons; others, which are anmuals, so to speak, die off themselves at the approach of winter, and leave only their esgss to vouch for them and to eontinue the race on the return of summer. A few beetles and other insects split the difference by hibernating in the pupa or chrysalis conclition, when they would have to sleep in any case, and emerging as full-fledged winged forms at the end of the winter. But on the whole the commonest way is for the plant or animal itself in its adult shape to lurk in the warm mud of the bottom daring the cold season.

In No. I we have an excellent illustration of this most frequent type, in the person of the beautiful pointel pond-snatil, a common fresh-water mollusk, with a shell so daintily pretty that if it did not abound we would prize it for its delicate transparent amber hue and its graceful tapering form, resembling that of the loveliest exotics. This pond-snail, though it lives in the water, is an air. breather, and therefore it hangs habitually on the surface of the pool, opening its lung-sac every now and then to take in a fresh sulp of air, and looking oddly upside down as it floats, shell downward, 
in its normal position. It hrowses at times on the submerged weeds in the pond ; but it has to come to the surface at frequent intervals to breathe; though, in common with most ayuatic air-hreathers, it call go a long time without a new store of oxygen, like a man when he dires, or a duck or swan when it feeds on the bottom-of conse to a much greater degree, becanse the snail is cold-blooded; that is to say, in other words, needs much less aëration. On a still evening in smmner you will often find the surface of the pond covered by dozens of these pretty shells, each with its slimy animal protruded, and each drinking in air at the top by its open-mouthed luns-sac.

In winter, however, at you see in No, 2, our pond-snail retires to the mud at the botton, and there quictly sleeps away the cold season. Being a cold-blooded gentleman, lie hibernates easily, and his snug nest in the oo\%, where he buries himself two or three inches deep, leaves him relatively little exposed to the attacks of encmies. Indeed, since the whole pond is then steeping and hibernating together, there is small risk of assault till spring comes round again.

Now, it may sound odd at first hearing when I tell you that what the animals thus do, the plants do also. "What?" you will say. "A plant more bodily from the surface of the water and bury itself in the mud! It seems almost incredible." But the accompanying illustrations of onc such plant, the curled pond-weed, will show you that the aquatic weeds take just as good care of 
themselves against winter cokl as the aquatic animials.

In No. 3 gen see a shoot of curled pond-weed pre paring to receive cold attacks at the approateh of antumm. You nuty perhatps have noticed for

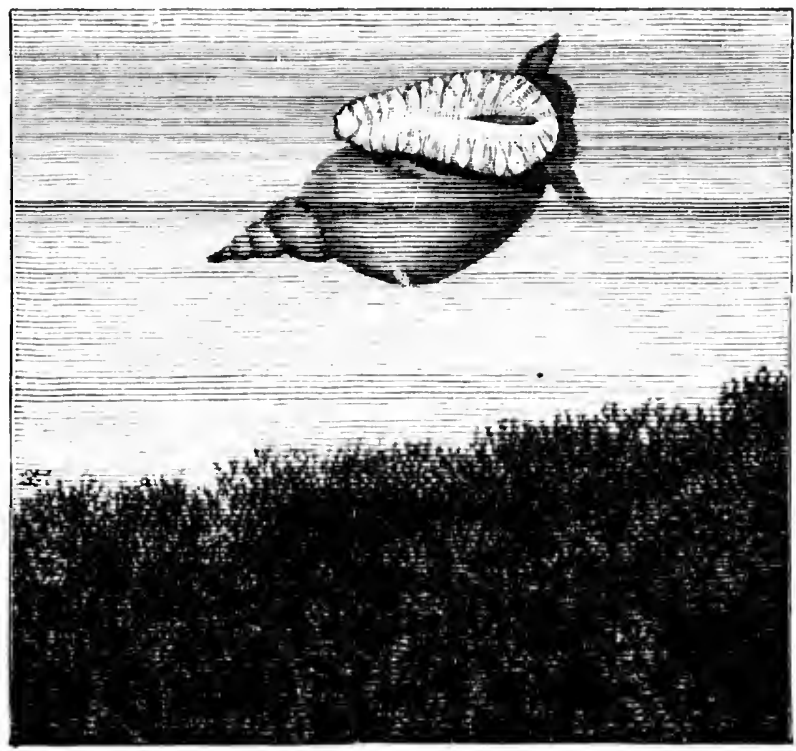

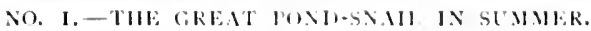

yourself that almost all plants of stannant waters tend to he freshest and most rigorous at the growing end-the upper portion; while the lower and olcler part is usually more or less eaten away by browsing water heasties, or incrusted by parasites, or draggled and torn, or water-logsed and mud- 
smeared. The really vital part of the plant at each moment is, ats a rule, the top or growing shoot. Nom, if the curled pond-weed were to let itself get overtaken bodily by winter, and its top branches or vigorous shoots fromen in the crust of ice which must soon coat the pond, it womkl be all

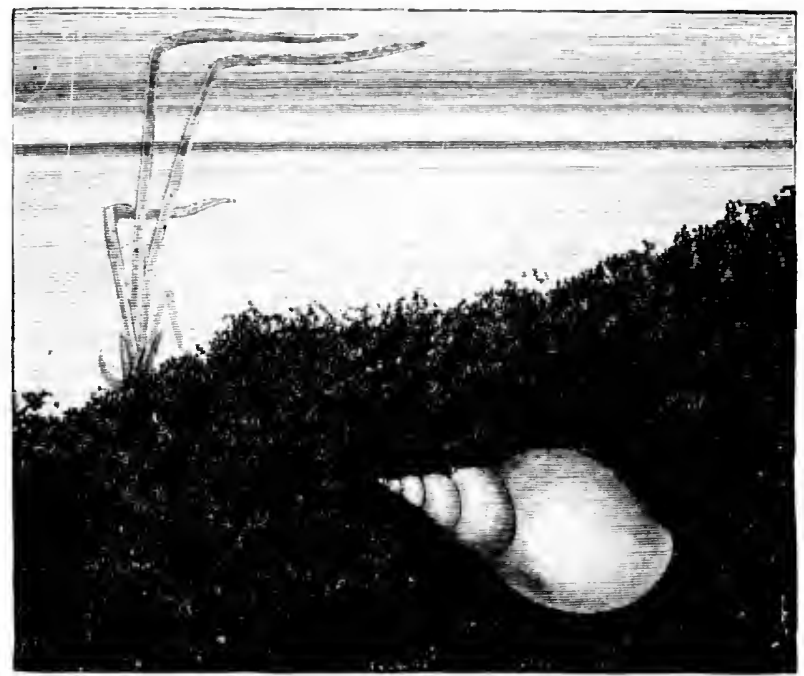

NO, 2.-THE IRLAT IOMH-S.AH, IN WISTER.

up with it. To suard astanst this calamity, therefore, the plant has hit upon a dodge as clever in its way ats that of om old friend the soldancllat, which batid be fuel to melt the slacier ice in the Alpine sprinsticle. Prevention, sats the curled pond-weed, is hetter than cure. So, in No. 3, you catch it in the very ate of settins ready certain 
specialised detachahle shoots, which are its liveliest parts, and in which all the most active protoplasm and chlorophyll (or living sreenstuff of the plant) are collected and laid by, much as food is laid by in the bulb of a hyacintl or in the tuber of a lahlia. These shoots are, as it were, leafy bulbs,

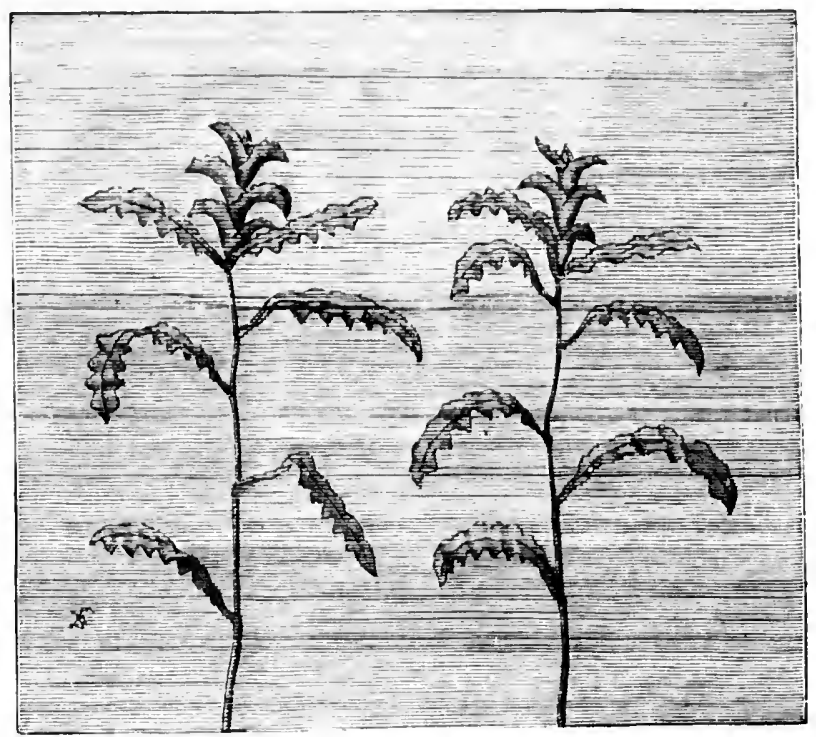

NO. 3. -THE CURLEL PONH-WLEL IROUUCING 1TS WINER SHOOTS,

meant to carry the life of the plant across the gulf of winter.

In No. + we come upon the next act in this curious and interesting vegetable drama. Most people regard plants as mere rooted things, with no will of their own, and no power of movement. 
In reality, plants, though usually more or less attached to the soil, have almost as many tricks and manners of their own as the vast mass of animals; they provide in the most ingenious and varied ways for the most diverse emeresencies. The winter shoots of the curled pond-weed, for

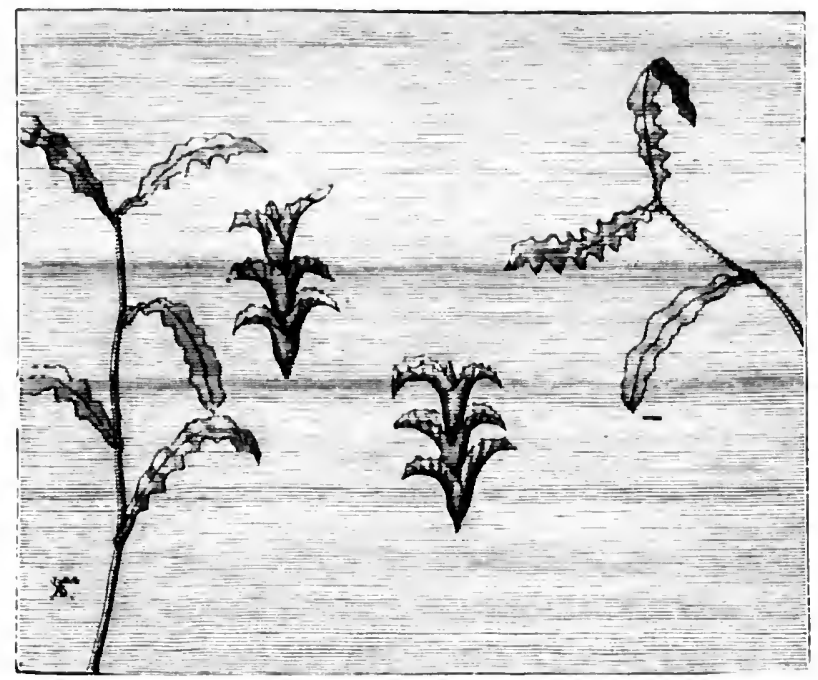

NO. 4.-THE SHOOHS IHETACHNG THEMSEINFS ANH SINKING, BEFOKE THE ['UNII FREEZES.

example, carrying with them the hopes of the race for a future seatson, are deliberately arranged beforehand with a line of least resistance, a point of severance on the stem, at which in the fulness of time they peaceably detach themselves. You cin note in the illustration how they have glided off 
gently from the parent stalk, and are now sinking by their own gravity to the warmer water of the bottom, which practically never freezes in winter. And the reason why they sink is that, being full of rich living greenstuff, they are heavier than the water, and heavier than the stem which pre-

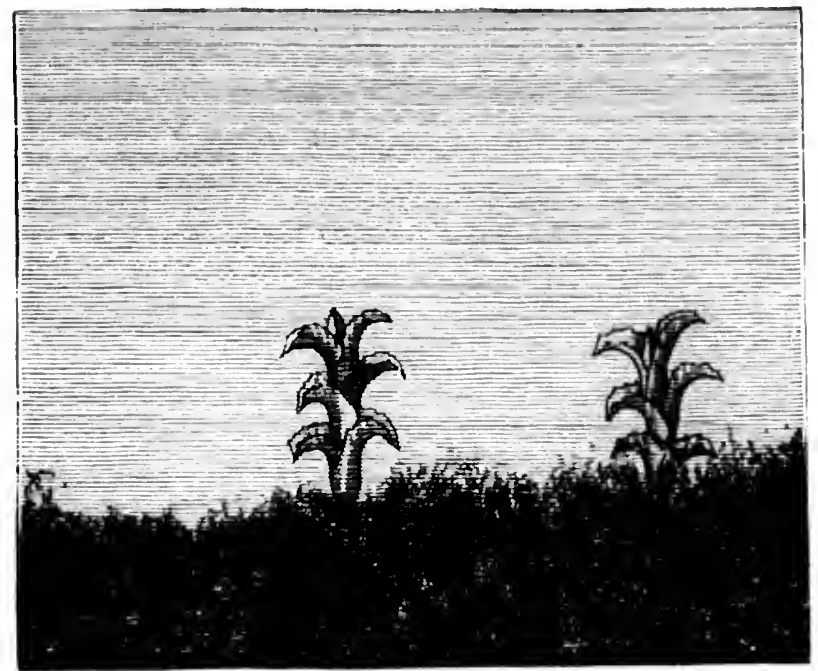

NO. 5-THE SHOOTS ROOTNG AT THE BOTTOM WHIL THE POND IS FROZEN.

viously floated them. This stem has many air cavities to keep it fairly erect and waving in the water: but the winter shoots have none, so that as soon as they detach themsetres they sink of their own mere weight to the bottom. You may notice that the leaves of deciduous trees in atutum 
have similar lines, ordained beforehand, along which they break off clean, so as not to tear or injure the permanent tissues; this is particularly noticeable in the foliage of the horse-chestnut, and also (in spring) in the common aralia, so often grown ats a drawing-room decoration.

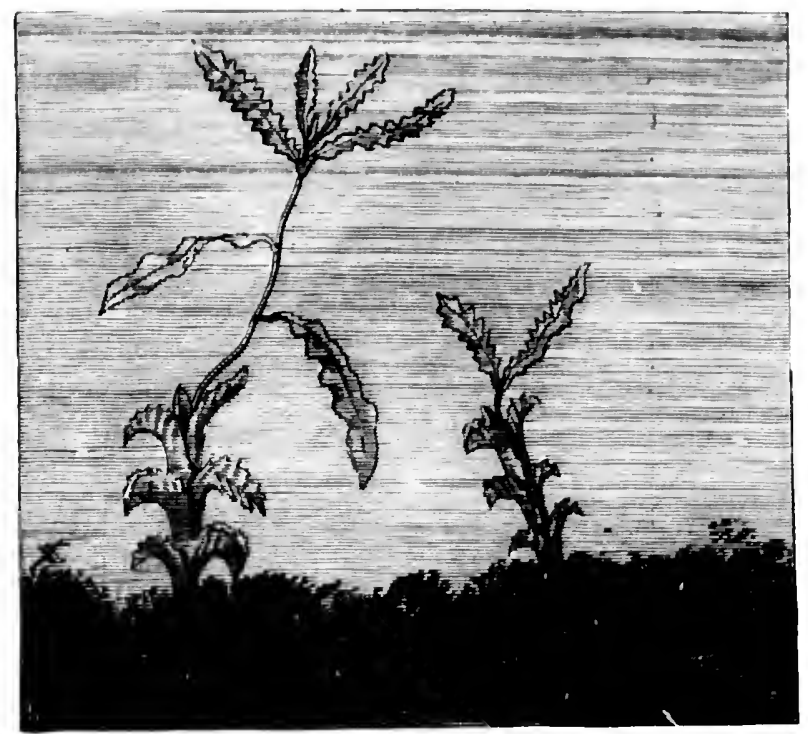

NO. 6.-THE SHOOTS IN SPRING HEGINNING TO SPROUT AGAIN.

No. 5 continues the same series, and shows us how the winter shoots, now sunk to the bottom, bore a hole and root themselves in the soft mud by their sharp, awl-like encls; after which they prepare to molergo their sleepy hibernation. 'They are now essentially detached bucls or cuttings, 
analogous to those which the gardener artificially lops off and "strikes" in our gardens. Only, the gardener's cuttings have been rudely sliced off with a knife, after the crude human fashion, while those of the pond-weed have been neatly released without injury to the tissues, the separation being performed by an act of growth, with all the beautiful perfection that marks nature's handicraft.

In the soft slimy mud, the shoots of the curled pond-weed lie by during the frozen period, hearing the noise of the gliding skates above them, and suffering slightly at times from the chill of the water, but actually protected by the great-coat of ice from the severest effects of the hard weather. By-and-by, when spring comes again, however, the shoots begin to bud out, as you see in No. 6, and once more to produce the original type of pondweed. The weed then continues to form leaves and stems, and finally to flower, which it does with a head or spike of queer little green blossoms, raised unobtrusively above the surface of the water. They are not pretty, because they do not depend upon animals for the transference of their pollen. I could tell you some curious things about these flowers, too, which find themselves far from insects, and destitute of attractive petals; so they have taken in clespair to a quaint method of fertilisation by bombardment, so to speak-the stamens opening in calm weather, and dropping their pollen out on the sancer-like petals, whence the first high wind carries it off with a hurst to the stigma or sensitive surface of the sister flowers. But that, 
though enticing, is another story, alien to the philosophy of the pond in winter. I will only add here that the pond-weed does not set its seeds very well, and that chances of dispersal are somewhat infrequent, so that irregular multiplication by these winter shoots has largely taken the place with it of normal multiplication by means of seedlings. At the same time, we must remember that no prudent plant can venture to depend for ever upon such apparent propagation by mere subdivision, which is not really (in any true sense) propagation at all, but is merely increased area of growth for the original parent, split up into many divergent personalities; so that the curled pond-weed takes infinite pains all the same to flower when it can, and to discharge its pollen and disperse its seed as often as practicable. Only by seedlings, indeed (that is to say by fresh blood - truly new individuals), can the vigour of any stock be permanenily secured.

Sometimes, again, the entire plant retires to the depths in winter, like the pond-snatil. This is the case with that pretty floating aquatic lily, the watersoldier, whose lovely flowers make it a frequent favourite on ornamental waters. In summer it floats; but when winter comes it sinks to the bottom, and there rests on the mud till spring returns again.

In No. 7 you see low another familiar and fascinating denizen of the pond, the little whirligig beetle, provides his winter quarters. The whirligig is one of the daintiest and most anusing of the inhabitants of our ponds. He is a small round 
beetle, in shape like a grain of corn; but as he is intended to sport and circle on the surface of the water in the broad sunshine, he is clad in glistening mail of iridescent tints, gorgeous with bronze and gold, to charm the eyes of his fastidious partner. You seldom see whirligigs alone; they generally dart about in companies on the surface of some calm little haven in the pond, a clozen at a time, pironetting in and out with most marvellous gyrations, yet never colliding or interfering with one another. I have often watched them for many minutes together, wondering whether they would not at last get in one another's way: but no; at each apparent meeting, they glide off in graceful curves, and never touch or graze. They go on through figures more complicated than the Lancers or Sir Roger de Coverley, now advancing, now retreating, always in lines of sinuous beauty, without angularity or strain, and apparently without premeditation; yet never for a second do they interfere with a neighbour's mazy dance, often as they cross and recross each other's merry orbits. Dear little platyful things they seem, as if they enjoyed existence like young lambs or chikdren. Sociable, alert, for ever sambolling, they treat life as a saraband, but with a wonderfully keen eye for approaching clanger. They look at times as if you could catch them without trouble; yet put down your hand, and off they dart at once to the sottom, or elude you by a quick and vigilant side movement, always on the curve, like a good skater or a bicyclist. 
This rapid skimming in eurves or circles on the surface of the water is produced in a most interesting way by the co-operation of the various pairs of legs, which I can best explatin by the analogy of the bicycle. The two shorter and active hind-legs produce the quick forward dart, just as the main

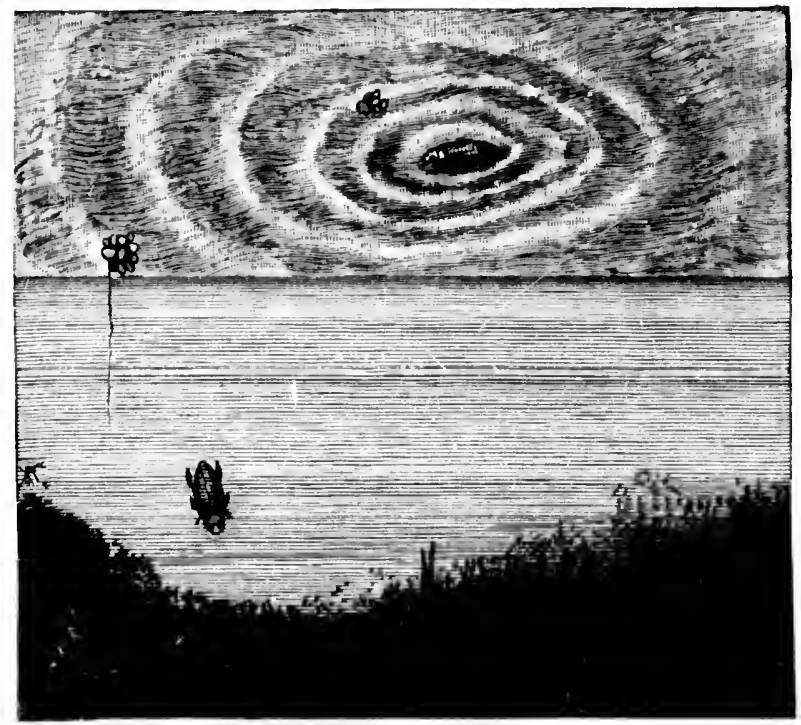

NO. 7.-THE WHIRGGHA BEETHE IN SUMMER, DANCING.

motion of the eycle is given it by the back wheel; the longer front legs act like the front wheel of the eycle in altering the direction; one of them is jerked out to right or left, molderwise, and gives the desired amount of curve to the resulting motion according to the will and necessities of the insect. 
The steering of a Canalian canoe comes very near it. Anybody who has sculled or rowed, indeed, knows well the extraordinary ease with which a boat can be shored off instantaneously from another, or the marvellous way in which gliding curves can be produced on the almost unresisting surface of the water. The whirligig beetle has a perfect steering apparatus in his long and extensible fore-legs, and by their means he performs unceasingly his play of merry and intricate evolutions.

When whirligigs are alarmed, howerer, they dive below the surface as one of a pair is cloing in No. 7, and carry down with them a large bubble of air, for breathing purposes, entangled in the joints of their complicated legs and the under parts of their bodies. On this quaint sublacustrine balloon they subsist for breathing till the danger is past and they can come to the top again.

Early in April, when the weather is fine, you begin to see the whirligis beetles dancings in and out in companies, like so many water-fairies, on the still top of the pond. They prefer calm water; when the wind drives little ripples to the eastern end of the pool, you will find them practising their aquatic gymnastics uncler lee of the shore on the western side; when an east wind ruffles the western border, you will find them gyrating and interlacing, coquetting and pirouetting, by the calmer eastern shallows. As they move in their whirls, they form little transient circles on the water's top, which spread concentrically; and the mutual interference 
of these widening waves is almost as interesting at times as the astonishing velocity and certainty of movement in the beetles themselves. So, all summer long, they continue their wild career, seeming to earn their livelihood easily by amusing them-

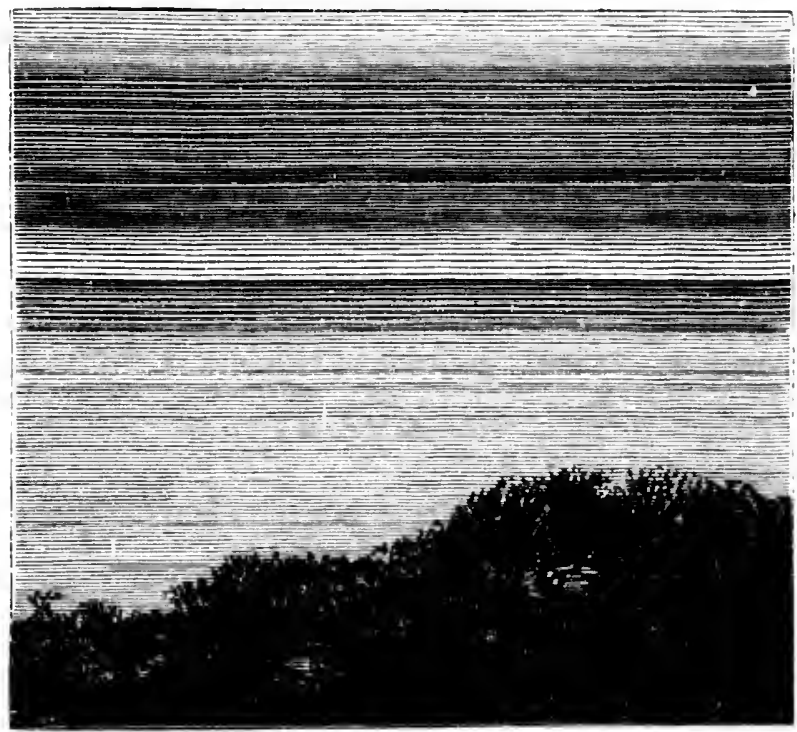

NO. 8.-WIIRI.IGIG BEETIIS IN WINTER, SIFFPING.

selves. But as soon as winter approaches, a change comes o'er the spirit of their dream. They retire to the depths, as you may observe in No. 8, and bury themselves in the mud while the pond is frozen over. During this period they inclulge in a good long nap of some five or six months, and, 
awaking refreshed in April, come to the surface once more, where they begin their syratory antics all over again, da capo. It is a merry life; and though the whirligig can $\mathrm{fly}$, which he does occasionally, 'tis no wonder he prefers his skimming existence on the still glassy sheet of his native waters.

The two larger British water-beetles, which are such favourite objects in the aquariums of young naturalists, do not lead quite so exclusively aquatic a life; they pass their youth as larve in the pond, and they return to it in their full-winged or beetle stage, being most expert divers; but they both retire to dry land to molergo their metamorphosis into a chrysalis, and they spend their time in the pupa-case in a hollow in the ground. Something similar oceurs with many other apuatic animals, which are thus conjectured to be the descendants of terrestrial ancestors, whom the strugsle for life has forced to embrace the easier opening afforded by the waters.

In this respect, that rather rare and beantiful little water-plant, the frogbit, shown in No. 9, has a life-history not unlike the career of the water-beetles. It is a quaint and pretty herb, which never roots itself in the mud, like the curled pond-weed, but floats freely about on the surface, allowing its long roots to hang down like streamers into the water beneath it. The short stem or stock is submerged; the leaves expand themselves freely and loll on the surface. Like most other floating water-leaves which thus support themselves on the top of the water, they are almost circular in form 


\section{A Frozen WORLD}

-a type familiar to all of us in the white and yellow water-lily, and also in the beatutiful little fringed limmanthemum. The reasen why floating

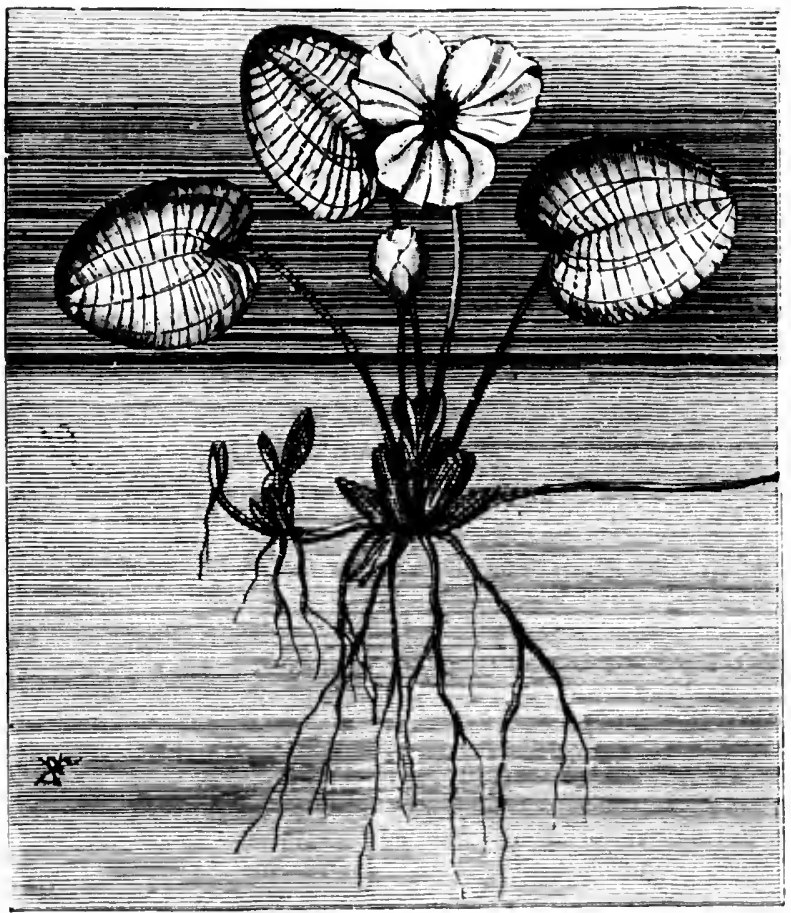

NO. 9.-THE FROGBIT IN SUMMER, FLOWERING.

leaves assume this circular shape is easy to perceive; they need no stout stalk to support them, like aerial foliage, the water serving to float them on its surface; and as they find the whole surrounding 
space free from competition, with no, other plants to interfere with them, as in the erowded meaclows and hedgerows of the land, they spread freely in the sunshine on every side, drinking in from the air the carbonic acid which is the chief food of plants. In short, the round shape is that which foliage naturally assumes when there is no competition, no architectural or engineering difficulty, plenty of food and plenty of sumshine.

The frosgit ats a whole, then, is not submerged like the curled pond-weed; it floats, not rooted, but free. Yet when it comes to flowering, it has to quit the water, just like the great water-beetles, and emerge upon the open air abore, so ats to expose its flowers to the fertilising insects. These flowers are extremely delicate and beautiful, with three papery white petals, and a yellow centre; they make the plant a real ornament to all the ponds where it fixes its residence. The males and females grow on separate plants, and aquatic flies act as their ambassadors. Such is the summer life of the froghit, while fair weather lasts; but, like all other pond denizens, it has to reckon in the end with the frozen season.

It does so in a way slightly different from, though analogous to, that of the curled pond-weed. No. io shows you the froghit after the flowering season is over, when it begins to anticipate the approach of winter. It then sends out slender runners, like those of the strawberry vine, on the end of each of which is formed a winter hud, which answers to the winter shoots of the curled pond-rveed. By- 
and-by the pond will free\%, and the floating leaves of the froghit will be fromen and killed with it. But the prudent plant provides for its own survival

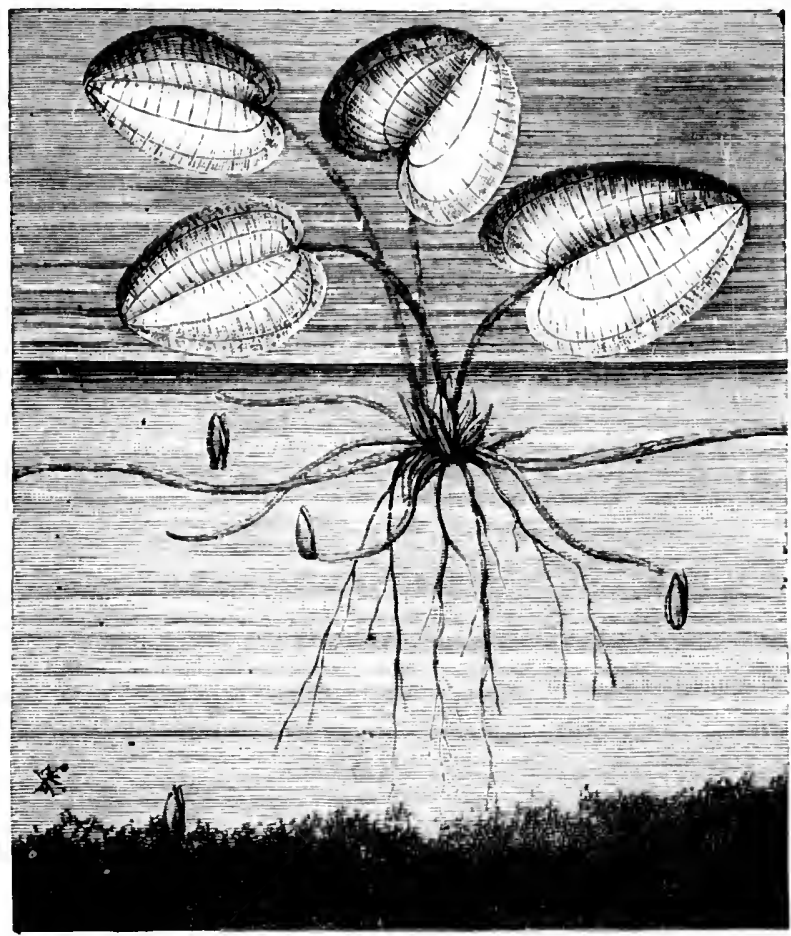

NO. IO.-THE FROGHIT DETACIING ITS WINTHR BUDS, WHICH SINK TO THE BOTTOM.

in the person of its offshoots, which are not its young, but integral parts of its own indivicluality. It fills them with starch and other rich foodstuffs 
for growth next season. About the time when the pond grows cool, the bucks detach themselses, like the winter shoots of the pond-reed, and slowly deseend by their own weight to the bottom. But they do not root themselves there, as the pond-weed shoos clid; they merely lie by, like the whirligis bectles, as you can see one of them preparing to do in the keft-hand eorner of No. io. NII the living material is drained from the leares into these winter bulbs. The pond freeses orer, and the remuant of the thoating leares decaly ; but the bulbs lurk quietly in the warm mud of the bottom, protected by a corcring of close-fitting scaleleaves.

In No. I I we learn the end of this quaint little domestic clrama. Spring has come, and the pond hats thawed asain. The winter huds of the froghbit now undergo certain spongy internal changes, due to warmth and srowth, which make them lighter - lessen their specific gravity. Air-cells are developed in them. So they begin to rise asain like bubbles to the surface. You can see in the illustration one hud still entangled in the slime on the hottom; another just starting to emerse ; a thircl rising; and a fouth and fifth on the surface of the pool. Two more have already risen; one of these is just putting forth its first few kidney-shaped leaves; another hat now grown pretty strong, and is sencling ont a rmuner, from which a third little plant is even berginning to develop. In time, humdreds of such rummers are sent forth in every direction, till the surface of the pond, in suitable 
places, is covered with a network of tangled and interlacing frosbits. They always seem to me in this way the plant-comnterparts of the whirligsig beetles; and it is hecause of this queer analogy in their mode of life that I have figured the two here in such close connection.

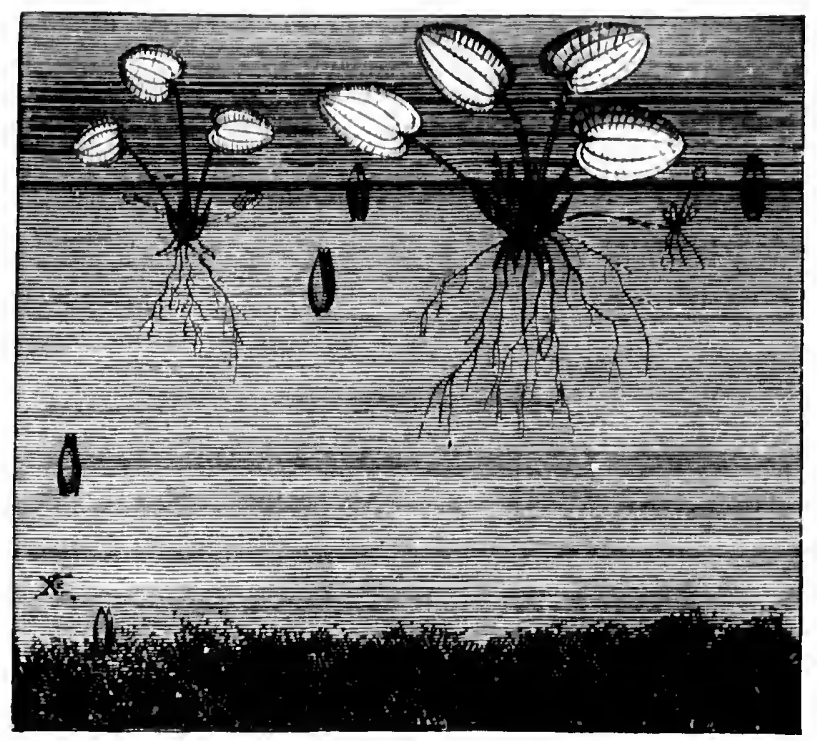

NO. II.-TIIE BUIS RISING AGAIN IN SPRING, ANI SPROUTING; INOA NETWORL.

Indeed, I hope I have now begun to make it clear to you that the difference of habit between plants and animals is not nearly so vast as most people imagine. It is astal to think of plants as merely passively existing. I lawe tried, here and 
elsewhere, to lay stress rather upon the moments in life when plants are doing somelling, and thus to suggest to $m y$ readers the close resemblance which really exists between their activities and those of animals. The more you watch plants, the more will you find how much this is true. And in a case like that of a pond frozen in winter, where both groups have to meet and face the self-same difficulty, it is odd to note how exactly similar are the various devices by which either group has suceeeded in sumounting it.

When you skate carelessly over the frozen pond in winter, you never perhaps reflect upon all the wealth of varied life that lies asleep beneath your feet. But it is there in abundance. The smaller newt, to be sure, has gone ashore to hibermate: but his great crested brother lurks sommolent in the mud, like a torpid bear or a sleeping dormouse. Frogs huddle buried in close packed groups at the centre, massed together in the soft ooze for warmth and company. Many kinds of aquatic snails slumber peaceably hard by, with various beetles beside the whirligigs. As for egges and spawn and larve or pupae, as well at petty crustaceans, you could count them by the dozen. Seeds are there, too, and buried plants of water-crowfoot, and ivinter shoots and winter buds, and a whole world of skulkers. The pond seems dead, if you look only at its hard and frozen top; hut in its depths it encloses for kind after kind the manifold hope of a glorious resurrection. Let May but come back with a few genial suns, and forthwith, the water- 
crowfoot spreads its white sheet of tender hloom; the whirligig clances anew; the newts acquire their red and orange spots and their decorative crests; strange long-legged creatures stalk on stilts over the glass of the calm bays, and tadpoles swarm black and fat in the basking shallows. The pond, it seems, was not dead but sleeping. Spring sounds its clarion note, and all nature is alive again. 


\section{$\mathrm{X}$ \\ BRITISH BLOODSUCKERS}

I

WRITE this title with peculiar pleasure, because it is so nice to be able for once to apply it literally. With its figurative use 1 am already too familiat. In some tropical conntries the freeborn Britons who are sent out in the Government employment to protect the natives or the coolies or the negroes, as the case may be, from their ausgressive brethren, are commonly known to their planter neighbours as "British bloodsuckers" -apparently because, like most other members of Civil Services elsewhere (except the Turkish), they get paid for their services. This use of the phrase is so well known to me, even as applied to myself, that I rejoice in being able to employ it here, without political prejudice of any sort, with reference to the habits of the mosquito and the horse-fly. Nobody, I suppose, is interested to deny that mosquitoes and horse-flies do suck blood; nobody feels the faintest sympathy for the miscleeds of those sanguinary and unpleasant ereatures. Now, it is always delightful to find a lawful outlet for our evil passions: all the worlel turns out to hunt at mad dog. I love to flick the heads off tall thistles 
with my stick as I pass, and salve my scruples with the thought that they are the deadly enemies of the agricultural interest. If there were no thistles, there would be nothing in the shape of a large and conspicuous flower whose head one could knock off with a clear conscience.

But at the very outset, I foresee a destructive criticism. "The mosquito," you wiil say, "is not a British bloodsucker." Pardon me ; there, you labour uncler a misapprehension. Everybody knows that there are gnats in England. Well, a gnat is a mosquito and a mosquito is a gnat. Like our old friend, Colonel Clay, they are the same gentleman under two different aliases. Or, rather, since it is only the female insect that hites, and only the bite that much concerns humanity, I ought perhaps to say the same lady. The difference of name is a mere question of nomenclature, and also (as with many other aliases) a question of where we happen to meet them. When a mosepuito is seen in England, he or she is called a gnat ; when a gnat is seen in Italy or Egypt, he or she is called a mosquito. But, as this is a fundamental point to our subject, I think we had better elear it up once for all before we so any farther. It is not much use talking ahout mosquitoes muless we really decicle what particular creature it is that we are talking about.

There is not one kind of snat, or one kind of mosquito, hut several kinds of them ; and both names are loosely applied in conversation to cover a large variety of related small tlies, almost all of 
them members of the genus Culex. The one point of similarity between the whole lot lies in the fact that they all suck bood ; whenever a blood-sucking culex is liglited upon in Englated it is called a gnat; while whenever one is found in any other part of Europe, Asia, Africa, or America, we say it is a mosquito. That is just a piece of the wellknown British arrogance; they will not admit that there are such renomous beasts as mosquitoes in England, and therefore, when found, they call them by another name, and fancy they have got rid of them. As a matter of fact, mosquitoes of one sort or another oceur in most comntries, if not in all the world; they are nost numerous, it is true, in the tropies and in warm districts generally; but they also abound in Camada, Siberia, Russia, and Lapland. Even in the Aretic resions, they eome ont in swarms during the short summer; and wherever ponds or staguant waters abound in Finlaud or Alaska, they hite yuite ats stlecessfully and industriously while they last as in Ceylon or Jamaica. At least a hundred and fifty kinds are "known to science," and of these, no fewer than thirty-tive ocent in Europe. There are nine in Britain. Most of the European species bite quite hard enough to be popularly ranked as mosquitoes ; the remainder are called by the general and inclefunite name of flies - a vague term which covers as large an acreage of evil as charity.

In hot summers, rou will often read in the papers a loud complatut that "mosyuitoes have made their appearance in England," most often in 
the neighbourhood of the London docks; and this supposed importation of renomous foreign insects is usually set down to the arrival of some steamer from Bombay or New Orleans. The papers might almost as well chronicle the "arrival" of the cockroach or of the common house-fly. There are always mosquitoes in England; and they bite worse in very hot weather. Occasionally, no doubt, some stray Mediteranean or American gnat, rather hungrier than usual, does cross over in water in the laraal form and effect a lodgment in London for a week or two ; but only a skilled entomologist conkl distinguish him from a native, after careful examination. Let it be sranted then, as Euclid says, that there is no essential difference between a gnat and a mosyuito, and let us admit that the same name is applied in hoth cases to a large variety of clistinct but closely related species. After which preliminary clearing of the groumd, we will proceed yuietly to the detated deseription of one such typical bloodsucker.

In justice to India, however, I ought perhaps to add that the particular mosyuito chosen for illustration by Mr. Enock is not itself a native Briton, hut an inhabitant of lndiat. It is thus only British in the wider sense of heing a denizen of her Majesty's dominions, on which the sun never sets, and the bur\% of the mosepuilo never ceatses. On the other hand, it differs so slightly from the commonest English gnat that nobody but a trained entomologist conld crer detect the difference; and even he could only discoser it in the adult inseet 


\section{Flashlights ox Natere}

hy minute variations in the antenne and other almost microscopic peculiarities. Incleed, if I hadn't told you this was an Indian mosquito, you would never have discovered that it wasn't a Fenland snat.

The mosquito is in a eertain sense an amphihious animal ; that is to saly, durings the course of its life, it has tried both land and water. It hegins existence ats an aymatic ereature, and only steps

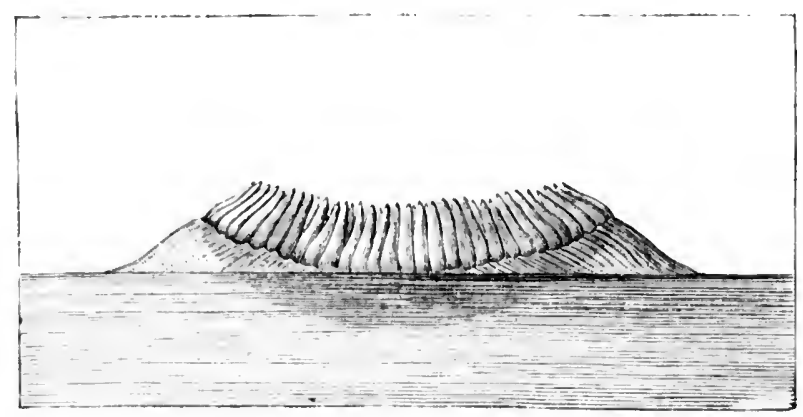

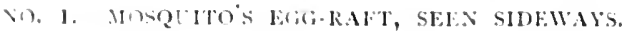

ashore at last 10 fly in the open air when it hats arrived at its atult form and dass of discretion. The mother mospuito, thitting in a clond-like swarm of her kind, hatint for the most part moist and watery spots in thick woole or marshes, and lays her timy esses on the surface of some pool or stasnant water. They are deposited one hy one, and then gilued ingether with a ghtumous secretion into a little raft or herat, shown in No. I, which floats about freely on the pond or puddle. It looks just 
like the compentional representations of the "ark of hulrushes" provided for the infant Mones. An inclustrious mother will laty some two of these

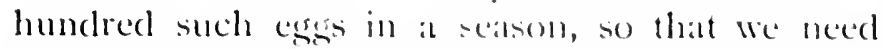
not woncler at the sreat colbums of mospuiteres that often appear in dimp places in smmmer. No, 2 shows the sime raft seen from alsore, and ex-

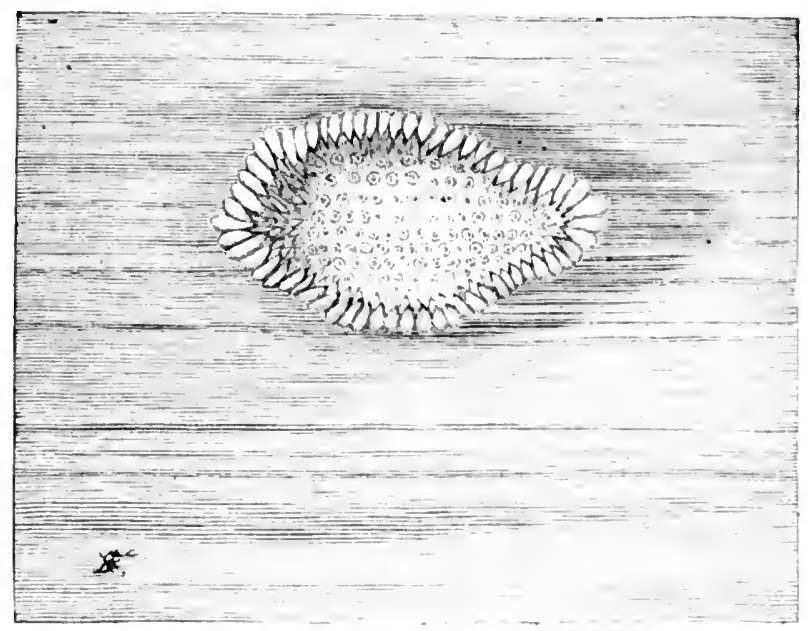

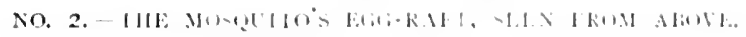

collently illustrates its admirahle bo:t-shaped or satuer-shaped eomstruetion.

After ahout thece das tome, the exss besin to

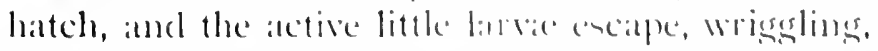
inte the watter. Xo. 3, which in collingerel forty diameters, exhibits the stitsen of the hatehing process. A sort of lid or doen at the lower end of the 
floating egg opens downward into the water, and the youns mosquito slicles off with a jerk of the tail into its native marshes. Almost everybody who has travelled in Asia, Africa, or America, must be familiar with these little brown clarting larve,

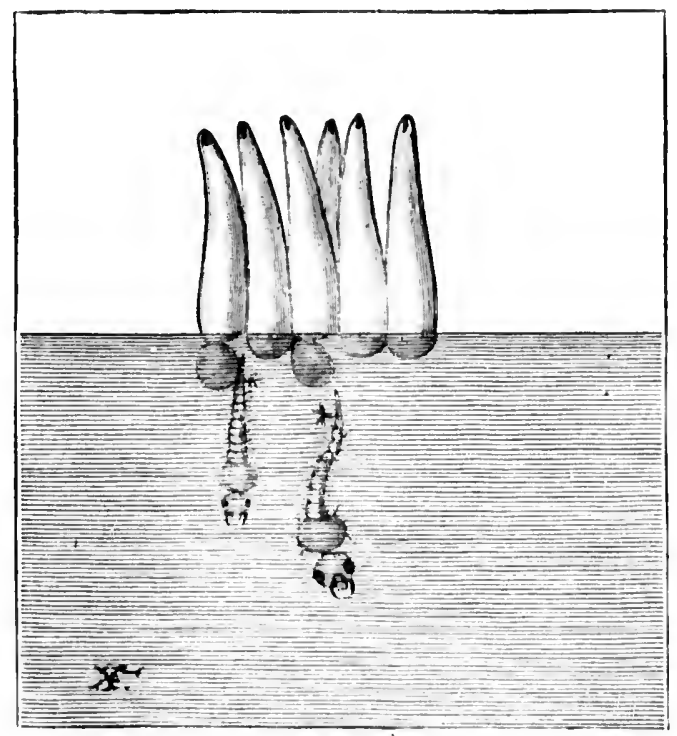

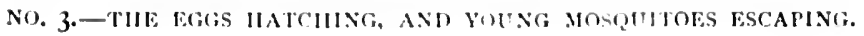

which occur abundantly in the soft water in jugs and wash-hand basins. Brown, l saly roughly, because they look so at a casual glance; lout if you examine them more closely you will see that they are rather delicately sreen, and often mottled. It is not easy to catch them, however, so quickly 
(lo they wriggle; you try to put your hand on them, and they slip through your fingers; you have caught one now, and, hi presto! before you know it, he is twirling off to the other side and disporting himself gaily in aquatic sambols. Nevertheless, he is at creatture well worth observing, this larva. Get him still under the microscope (which is no easy matterto insure it, you must supply him with only the tiniest possible crop of water) and you will then perceive that he has a distinct head, with two

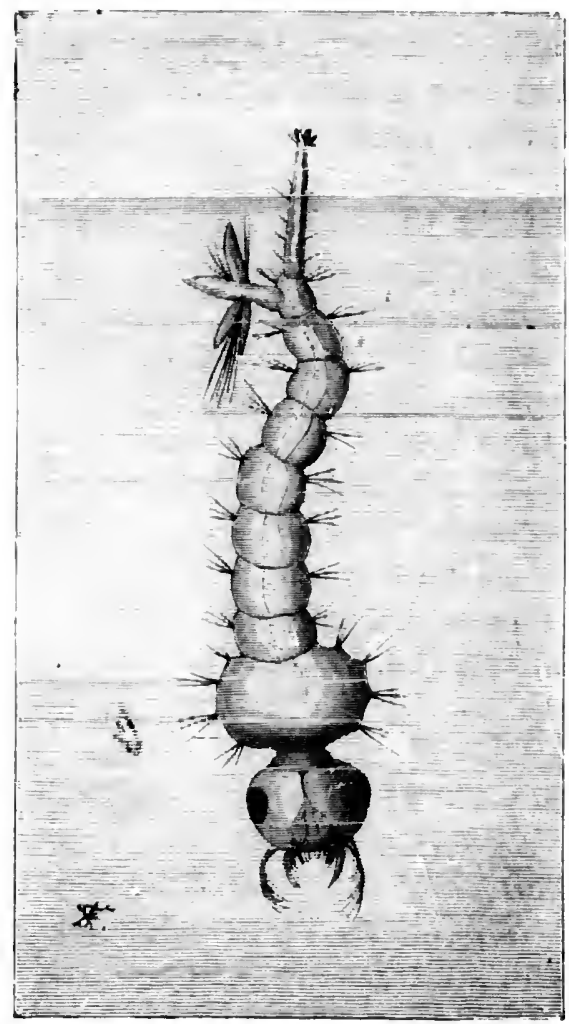

No. 4. - THl: MOSQITTO-IARVA ix HIS

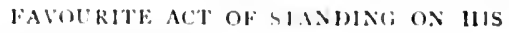
IIIA) AVI) BREATIIIII, large dark eyes, and that behind it comes a globular body, and then a tail of several quickly-moving segments. No. 4 
is a portrait of the larva in his full-grown stage, near the surface of the water. He is about half an inch long, and nimble as a syuirrel. You will observe on his head a sort of big moustache, set with several smaller hristles. This moustache (which consists for science of a pair of mandibles) is kept always in constant and rapid motion; its use is to create an eddy or contimuous current of water; which brings very tiny animals and other objects of food within reach of the voracious larva's mouth ; for young or old, your mosquito is invariably a hungry subject. In point of fact, you may say that these hairy organs are the equivalents of hatnds with which the larva feeds himself. They vibrate ceatselessly.

At the opposite end of the hody, you will observe, there are two other organs, both equally interesting. One of them, which goes straight up to the surface of the water, and protrudes above it, is the larva's breathing-tube; for the mosquito breathes, at this stage, not with his head but with his tail; this ingenious mechanism I will explain further presently. The other organ, which in the illustration (No. + ) goes off to the left, and has four loose ends visible, serves its owner as a fin and rudder. It is the chief organ of locomotion-the oar or serew by whose means the larva darts with lightning speed through the water, and alters his direction with such startling rapidity. You will note that it is not unlike the screw of a steamer, and it answers for the animal the same general purpose. How effectual it is 
at a locomotive device ererybody knows who has once tried chivrying a few healthy mosquito latve round the brimming sea of his bedroom basin.

The breathing-tube deserves a little longer notice. By its means air is conveyed clirect into the internal air-chamnels of the insect, which do not form langs, but ramify like arteries all over the body. Wie carry our hlood to the lungs to be aerated; the insects carry the oxysen to the blood. To take in air, the larva fre. quently rises to near the surface, ats you see him doing in No. t; then he stands on his heald, cocks up his tail, and pushes

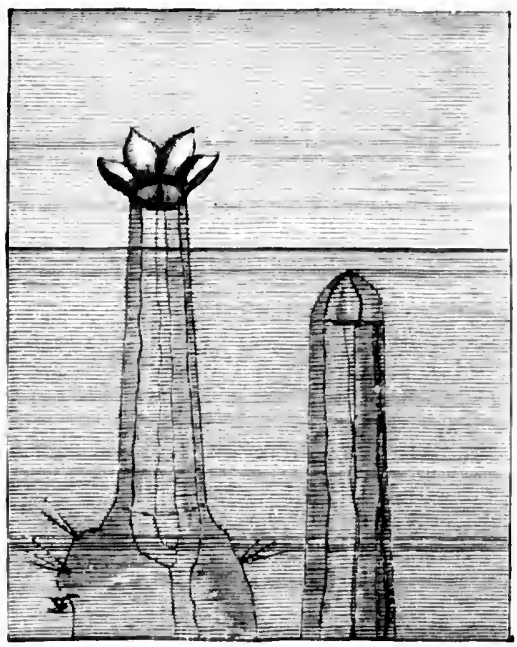

XO. 5. TIIE IARVA'S BRFATIIING-TUBE,

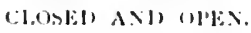
out lis atr-tube.

lndeed, when at rest this is his ustal attitude. No. 5, which, of course, is rery hignly masnified, shows his tail in the act of taking in a good gulp of oxygen. The little valles, or doors, which cover the air-tube are here opened radially, and the larva is breathing. 'T'o the right you see the position of the tube after he has taken in a long 


\section{Flashlights ON Natere}

(lraught of air (just like a whale or a porpoise) and is clarting to the depths assain. The tiny ralves or doors are now elosed, so that no water ean get in ; the larva will go on upon the air thus stored till all of it is exhansted; he will then rise once more to the surface, let out the breath loaded with carbonic acid, and draw in a fresh stock again for future use.

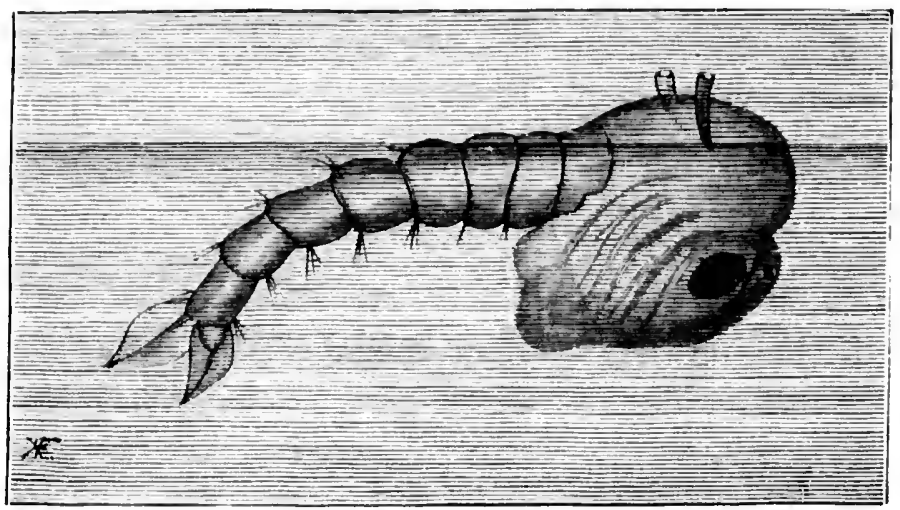

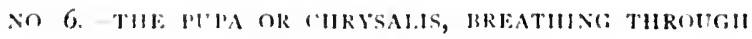
IIU IOKN-I,IKJ: TI BI:S

The young mospuito remains in the larval form for about a fortnight or three weeks, cluring the course of which time he moults thrice. As soon ats he is full-grown, he becomes a pupa or chrysalis-lies by, so to speak, while he is changing into the winged condition. No. 6 is a faithful portrait of the mosquito in this asge of transition. (I borrow the last phrase from the jourmalists.) 
Within the pupa-case, which is smaller than the larva, the inseet is bent clouble; in this apparently uncomfortable position, it hesins to develop the wings, the less, and the blond-sucking apparatus of the perfect mospuito. Nevertheless, ill-adlapted as such a shape misht seem for locomotion-with one's head tucked under, and one's eyes lookins downward-the mospuito in the pupat continues to move about freely, instead of taking life meanwhile in the spirit of a mummy in the mummycaste. By way of change, howerer, he now eats nothing-having, in fact, no month to eat with. But the most womlerful things of all is the alterat tion in his method of beathing. The pupa no longer breathes with its tail, but with the front part of its body, where twe little born-shaped tubes are developed for the purpose. You can see them in the illustration (No. 6), which is taken at the moment when the atetive and focomotive pupa has just come to the surface 10 breathe, and is floating, hack up, and head dombled under downwatrd, in a most comstraned position. The attitude reminds one of mothing so much at that of a bull, with his head hetween his lessi, molning forward to attack once. You ean see through the pupateatse the great dark eyes and the rudiments of the leses ats they form? below it.

No. 7 exhibits very prettily the next stange in this short erentful history the emergence of a female mosquito from her dressing-sown or pupatcase. She looks like a lady eming out of her 


\section{Flashlights ox Natike}

hall-cle'ss. As the pupa grows older, the skin or cate stands off of itself from the animal within, by a sort of strange internal shrinkage, and a bayer of air is thus formed between case and

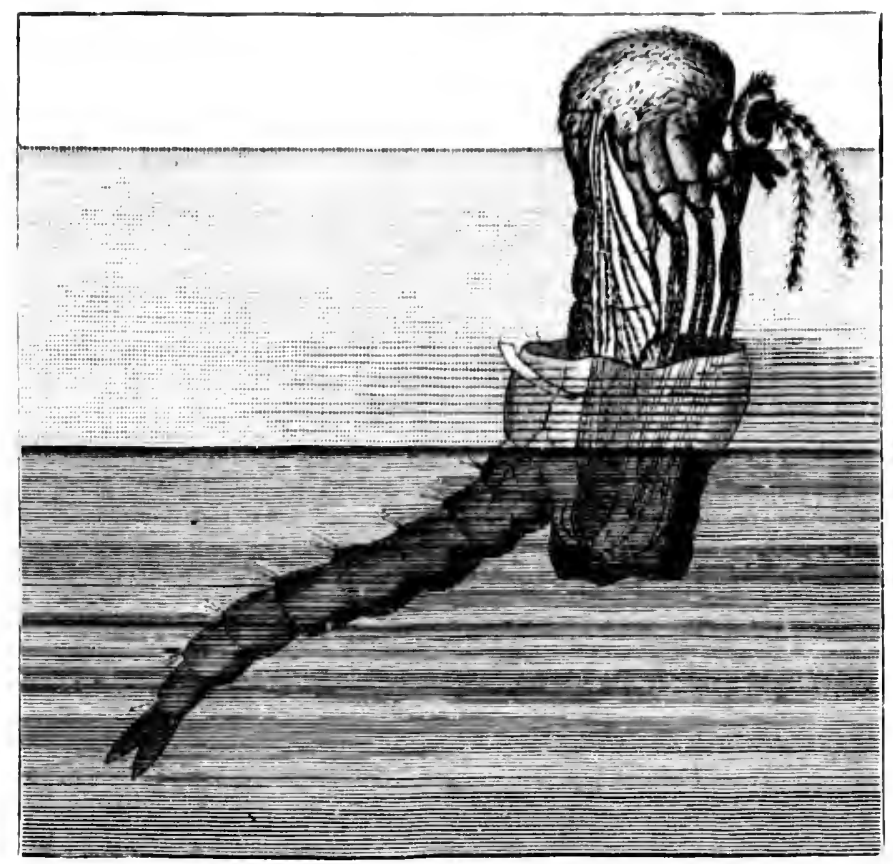

o. 7.-THE FEMALE MOSUTITO ABANDONING HER PUI' CASF.

occupant. This callses the whole apparatus to float to the surface, and enables the winged fly to make an effective exit. 'The new mosquito, looking still very hump-backed, and distinctly crouching, breaks through the top of the pupa- 
case (which opens by a slit), raises herself feebly and awkwally on her spindle shanks, and withdraws her tail from its swathing bandage. She hats grown meanwhile inte at rers different ereature from the aluatic larva: ohserve her long plumed antenne, her curious mouth-organs, her six hairy legs, and her delicate sante-like wings, all of them wholly distinet from her former self, and utterly morepresented by anything in the swimming insect. It is a marvellous transformation this, from a darting acpuatic with rudeler and tail, to a tlying terrestrial and acrial anmal, with legs and wings and manifold adapted appendages. At first, one would say, the new-fledged mospuito can hardly know herself.

In nature, however, nothings is ever wasted. The pupa-case, you would suppose, is now quite useless. Not a bit of it. Our landy utilises it at once as a hoat to float upon. She platuts her hong legs upon it gingerly, as you see in No. 8, where you can still make out the shape of the tail and the hornlike breathing-tubes of the pupa. Thus does she rise on stepping-stones of her dead self to higher things, in a more literal sense than the poet contemplated. Sou ohserve her above, in her natural size, and helow much masnitied. Sotice her beatutiful san\%y winss, matked with hairy reins, her pretty phome-like antennat, her spider-like jointed kess, and her hump of a body. She stands now, irresolute, meditatings flight and wonderins whether she dare unfold her light pinions to the breese. Soon, confidence and strensth will come to her; 
she will plim them on the stmmer air, and float awat carelessly, secking whom she may devour.

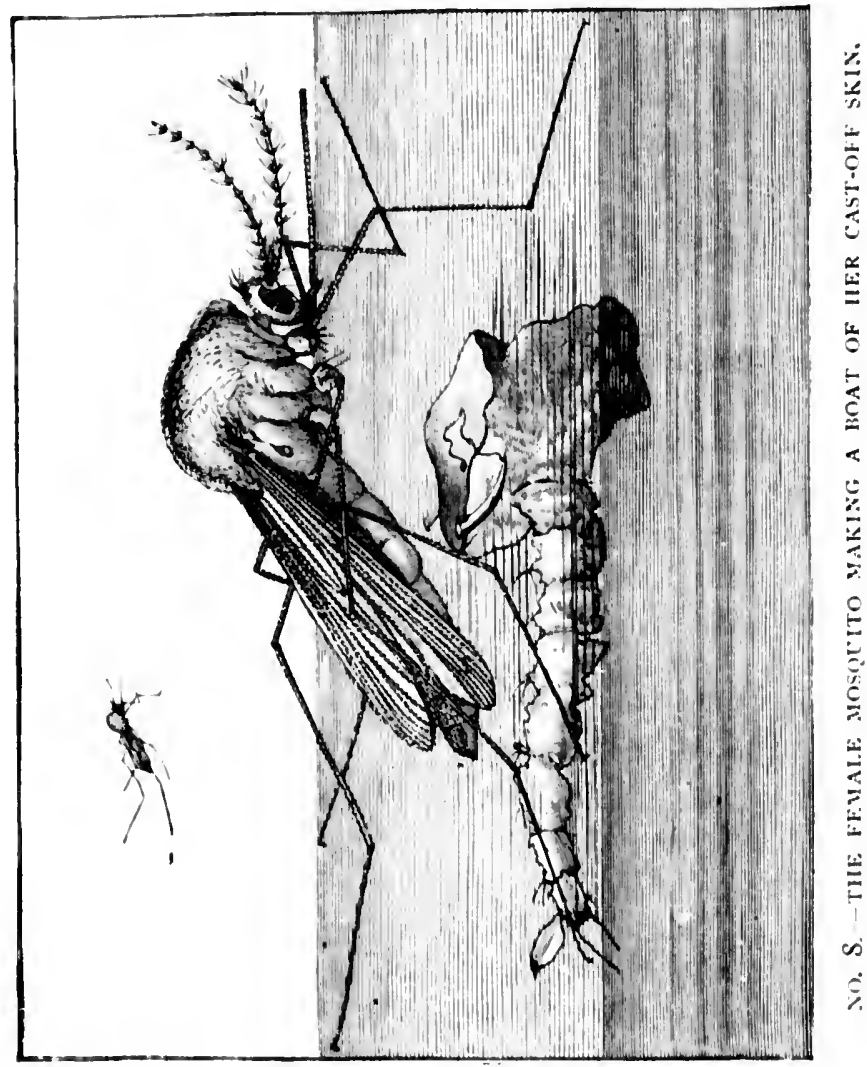

All this is what happens 10 a stlecesstul insect. But often the boat fails; the young wings get wetted; the mospuite cannot spread them: and 
so she is drowned in the very element which till now was the only place where she could support existence.

And here I must say a word in fatrome of the male as against the female moscpuito. In most species, and certaninly in the commonest British sollat, the mate fly never sucks hood at all, but passes (11) idyllic resgetarian existence, which might c'xcite the wammest praise from Mr. Bermated Shaw, in sipping the harmless nectar of thewers. He has,

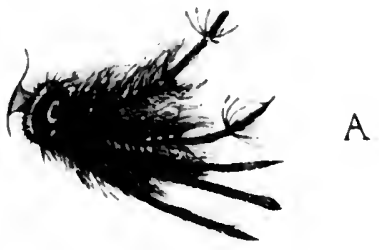
ii) point of fact. no werupon to attack us with. He is an mantmed honey-suclier.

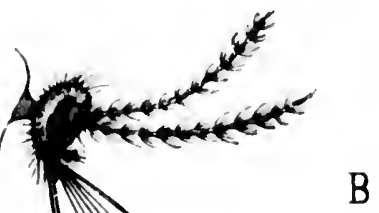

But the female is rery differently minded-at Mes- 
salina or a Brinvilliers, incongruously wedded to a vegetarian innocent. Even the very forms of the head and its appendages are quite different in the two sexes in adaptation to these marked differences of habit. No. 9 shows us the varieties of form in the male and female at a glance. Above (in Figs. A) we have the harmless vegetarian male. Observe his immocent sucking month, his bushy beard, his lack of sting, his obvious air of general respectability. He might pass for a pure and blameless ratepayer. B3ut I must be more definitely scientific, perhaps, and add in clearer language that what I eall his beard is really the antenne. These consist of fourteen joints each, litted with delicate circlets of hair ; and the hairs in the male are so long and tufted as to give him in this matter a feathery and military appearance, wholly alien to his real mildness of nature. Look close at his head and you will find it is provided with three sets of organs-first, the tufted antennae; second, a single sucking proboscis, adapted for yuiet flowerhunting and nectar-eating ; third, a pair of long palps, one on each side of the proboscis.

Now, heneath him, marked B, we get the head of his faithful spouse, the abandoned blood-sucking mosquito, which looks at first sight, I confess, much more simple and larmless. Its antenna have shorter and less hristling hatirs; its proboscis seems quiet enough ; and its palps are reduced to two mere horns or knobs, not a quarter the length of the bristly hushand's, on each side of the proboscis. But notice in front of all that she has 
five long lancets, guarded by an upper lip, which do not answer to anything at all in her husband's economy. Those five lancets, with their serrated points, are the awh or piercers with which she penetrates the skin of men or cattle. They correspond to the mandibles, maxillac, and tongue, which I shall explain hereafter in the mouth of the gadfly. How they work you can observe in the lowest figure, $C$. Here you have a bit of the hand of a human subject-not to put too fine a point upon it (which is the hesetting sin of mosquitoes), the artist's. He has delivered himself up to be experimented on in the interests of science. The sharp lancets have heen driven through the skin into the soft tissue beneath, and the bent proboscis is now enganged in sucking up the blood that oozes from it. If that were all, it would be bad enoush; but not content with that, the mosquito, for some mysterious reason, also injects a chop of some irritant thicl. I have never been able to see that this proceeding does her any sood, but it is irritating to us ; and that, perhaps, is quite sufficient for the ill-tempered mosquito.

Owing to the habits of the larva, mospuitoes are of course exceptionally ahundant in marshy places. They were formerly common in the Fen clistrict of England, but the drainings of the fens has now almost got rid of them, as it has also of the fererand-asue microbe.

As a rule, mosquitoes are nocturnal animals, though in dark woods, and alse in rery swampy districts, they often bite quite as badly through the 
daytime as at night. But when evening falls, and all else is still, then wander forth these sons (or daughters) of Belial, fown with insolence and blood. "What time the grey tly winds her sultry horn," says Milton; and that sultry horn is almost more anmoying than the bite which it precedes. You lie coiled within your mosquito-curtains, wooing sweet sleep with appropriate reflections, when suddenly, hy your ear, comes that still small voice, so vatstly more pungent and more irritating than the voice of conscience. You light a candle, and proceed to hunt for the anweleome intruder. As if by magic, as you strike your match, that mosquito disappears, and you look in vain through every fold and cranny of the thin gatuze curtains. At last you give it up, and lic down again, when straightway, "z-\%-\%-\%," the humming at your ear commences once more, and you begin the unequal contest all over anatin. It is a wat of extermination on either side you thirst for her life, and she thirsts for your hlood. No peace is possible till one or other combatant is finally satislied.

You can hest observe the mosquito in action, however, by letting one settle undisturbed on the back of your hand, and wating while she fills herself with your blood; you call casily watch her doing so with a pocket lens. Like the old lady in "Pickwick," she is soon "swelling wisibly." She gorges herself with blood, indeed, which she straightway digests, assimilates, and converts into the 300 eggs aforesaid. But if, while she is sucking, you gently and unohtrusirely tighten the skin of your 
hand by clenching your fist hard, you will find that she cannot any longer withdraw her mandibles; they are caught fast in your flesh by their own harpoon-like teeth, and there she must stop accordingly till you choose to release her. If you then kill her in the lisual mamner, by a smatt slap of the hand, you will see that she is literally full of blood, havings sucked a sood drop sif it.

The hummings somel itself by which the mosquito announces her approaching visit is produced in two distinct manners. The clecper notes which go to make up her droning songs are due to the rapid vibration of the female insect's wings ats she flies; and these vibrations are found by means of a siren (an instrument which measures the frequency of the waves in notes) to amount to about 3000 in a minute. The mosequito's wings must, therefore, move with this extratordinary rapiclity, which sufficiently accounts for the difficulty we have in catching one. But the higher and shriller notes of the complex melody are due to special stridulating oreans situated like little drums on the openings of the air-tubes; for the adult mospuito breathes no longer by one of two air-entrances on the tail or back, like the larva, hut by a number of spiracles, as they are called, arranged in rows along the sides of the holy, and communicating with the network of internal air-chambers. The curinass moscyuito music thas serererated hy the little drums serves almost beyond a dould at a means of attracting male mosepuitoes, for it is known that the loms hairs on the antenna of the males, shown in No. 9, 
Fis. $A$, vibrate sympathetically in misom with the notes of a tomingsfork, within the range of the somels emitted by the female. ln other words, hairs and drums just ambwer to onle another. We may, therefore, reasomahly conclude that the female singsi in order to pleatac and attract her wanderings matce, atsel that the antemuse of the male are oresans of heaving which catch and respend to the burzings music she pours forth bor her lower's rats. A whole

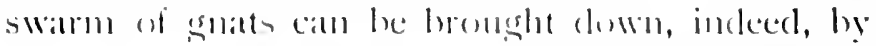

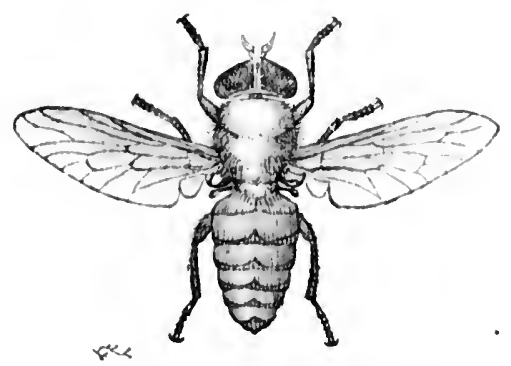

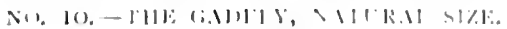
utterims the appropriate note of the race ; yoll call call Hem somewhat ats you call call male :3low-Woms by showings a light which they mistake for the female.

1 much larger and more powerful British bloolsucker.

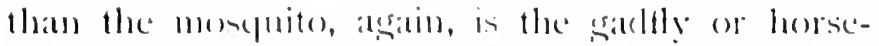
lly, whose life-size portrat Mr. Enock hats drawn for us in No. o. Mest people knom this fearsome beatst well in the fielels in summer. He hats a trick of actoling on the back of note's neck, and mekings a hole in one's skin with his sharp

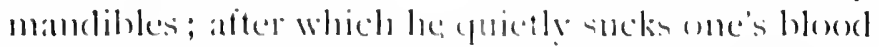
almost withont one's perecovins him. Horses in pastures are often terribly troubled by these persistent creatures, which make no noise, hut creep 


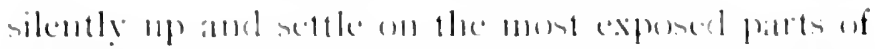

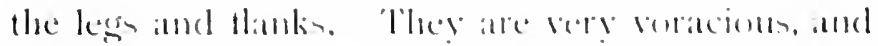

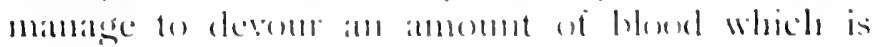
truly supprining.

A litte examination of the salth will show you, tow, ome impentant point in which it and all ofluer

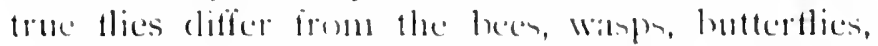
and the vast mans of erelinary innects. All the

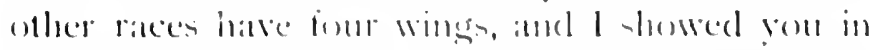
the case of the wanp the beatutiful mechatuism of hooks and groweren by which the hore and hind

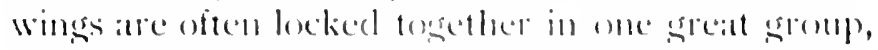

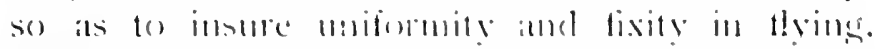
Amons the true tlies, howerer, incluclins not only

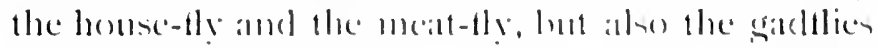

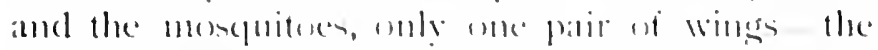

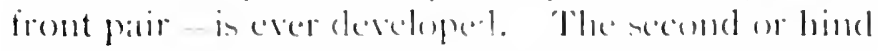
par is fechly reprenented hy a comple of time rudimentary wings, known an proinere all balancers, which yen eatn jum make out in the ticteds, like at couple of stalliced knohe, in the spated hetween the true wings and the tail or abloment. It is pretty cleatr that the exmmom ancesters of all these twe

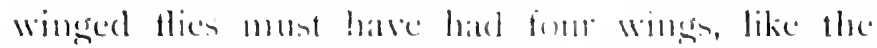
rest of the sireat elatos to which he belonged ; hut

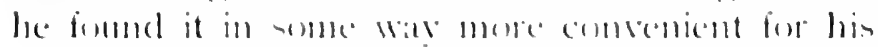

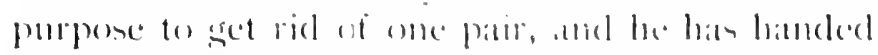
down that simsulat modification of stricture lo all

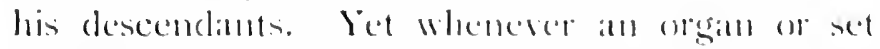

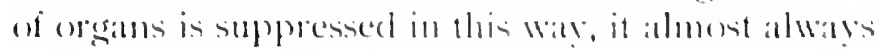
hatpens that rudinents or relice of the supporessed part remain to the latest senceations ; and thus the 
true fles still retain, in most cases, the two tiny pesisers or halancers, just te remind us of their descent from four-winged ancestors. Natture has no hahit more interesting than this retention of parts long since disused or almost disused ; hy their aid we are able to trace the genealosy af

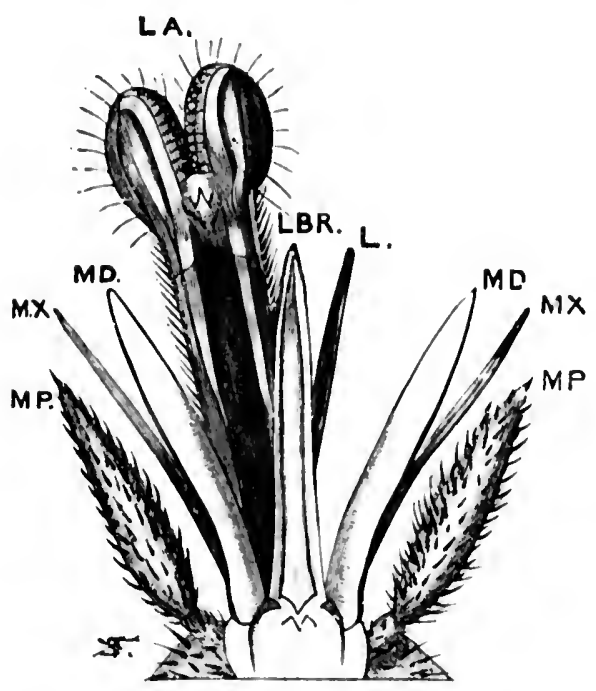

NO. II,-THE MAHFI'S I.ANCETS, HWH OTHER PARTS WF THI: IROBSHCLS. plants and animinals.

li1 No. 11 we have at dissected view of the mouth-organds and blood-sucking apparattus of the sadtly, inmensely enlatised, so ats to sluw in detail the mintestruc. ture. In life, all these separate parts are combined together into a compound sucker (commonly called the proboscis), which forms practi. cally a single tube or sheath; they are dissected out here for facility of comprehension. The longest part, marked $\mathrm{L} A \mathrm{~A}$ in the sketch, is the labium or lower lip, which makes up the mass of the tube ; it ends in two soft finger-like pads, which are fleshy in texture, and which enable it to fix itself firmly 
(like a camel's fort) on the skin of the victim. 'The srooved and danger-shaped orsan, marked I.BR, is the labrum, or upper lip; and the tube or sheath formed by the shotting together of these two pats encloses all the other organs. Combinerl, they form a trunk or proboscis, not mulike that of the elephant. But the elephaut is not a bloodsucker: lis trumk encircles no dangerous cutting weapon. It is otherwise with the sadtly, which hats a pair of shapp knives within, for lancins the thick stin of its mulnappl victims. These knives alle known as mandibles, and are marked MI) in the sketch, one on either side of the lahrum. They first pieree the skin; the maxiller, matked $\mathrm{MX}$, of which there are also a part, then lap up the hlood from the internal tissues. Finally, there is the true tongue or lingur, marked 1, which is the orgsan for tasting it. As to the moxillary palps, matked MlP, they do not form pant of the tube at all, hut stand outside it, and assist like hands in the work of manipulation.

This is how the month looks when fully opened out for microscopic examination. But as the tly uses it, it forms a closed tube, of which the labium and the labrum are the two walls, enfolding the lances or mandibles, and the lickers or maxillae, as well as the tonsue. Pack them all ally mentally, from $\mathrm{MX}$ to $\mathrm{MX}$, within the two covers, and you will then understand the nature of the mechanism. Look hack at Figs. B in No. 9, and you will there observe that all the parts in the mosquito answer to those in the gadfly. The long upper sheath is the upper lip: 
then come the lancets, the lappers, and the tongue, and last of all, the lower lip.

In No. 12, which is still more highly magnified, we have the essential parts of the blood-sucking apparatus mate quite clear for us. Here I,BR is the tip of the labrum, or upper lip, forming the front of the groove or sheath in which the lances work.

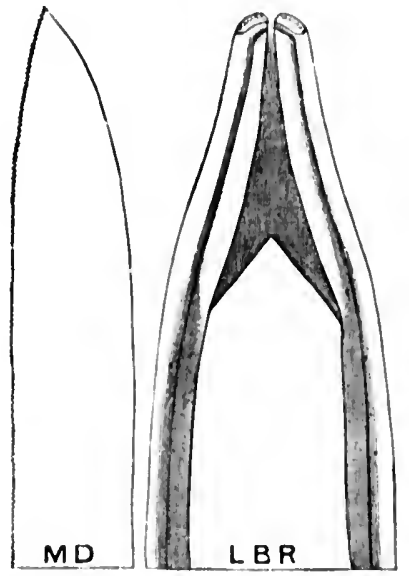

$x$

NO, 12,-THE CUTIX: Fl) (1) THE I.ANGTS, lts encl is hlunt, so ats to enable it to be pressedelose agsinst theminute hole formed hy the lanees. MID is the sharp tip of one of the two lances, with its serrated or salwlike cutting-edge ; this is the organ that cloes the serious work of imperceptibly piercing the skin ancl the tissues beneath it. MX is the tip of one of the maxille, or blood lappers, which suck or lap up the blood from the wound after the lances have opened it. I need hardly call your attention to the extraordinary delicacy and minuteness of these hard, sharp weapons, strong enough to pierce the tough hicle of a horse, yet so small that if represented on the 
same scale as the insect itself, you would fail to perceive them.

Is it not marvellons, too, that the same set of organs about the mouth, which we saw employed by the wasp for cutting paper from wood, and hy the ant for the varied functions of civilised ant-life, should be capable of modification in the butterfly into a sucker for honey, and in the wade tly into a cumning mechanism for piercings thick hides and feeding on the life-blood of superion amimals. Nature, it seems, is sparing of gromulplan, but strangely lavish of minor modifications. she will take a single set of organs, inherited from some early common ancestor, and keep them true in the main through infinite varieties; hut as habits alter in one species or another, she will adapt one of these sets to one piece of work and another to a secend wholly molike it. While she preserves throughout the similarity due to at common origin, she will vary infinitely the details and the minor structures so as to make them apply to the most divesse functions. Nothing shows this truth saore heautifully, and more varionsly, that: ine mouths of insects ; and though tine names by which we call the different parts are, I will admit, somewhat harsh and technical, I feel sure that anybody who once masters their meaning eammot fail to be delighted by the endless modifications hy which a few small instruments are made to fit an ever-increasing and infinite diversity of circumstances. 


\section{XI}

\section{A VIRY INTIIIIGIST PI.ANT}

DEOple whe have nevel had oceasion to ohserve plants closely often fall inte the erore of regiarding them as pratically dead - clead, that is to saly, in the sense of never doing or eontriving anything active. They kmow, of comse, that herbs and trees sorow and increatse; that they flower and fruit; that they put forth gited leatses in springs and lose them astain in antumm. But they picture all this as taking place without the knowledge or en-eperation of the plant itself they think of it ats clone for the tree or shrub rather than by it. Those, however, who have kept a close watch upon living steen things in their native condition have sencerally learned hy stow despees to take yuite a different view of plant morals and plant economy. They hegin to find out in the course of their observations that the life of a luerh is pretty much ats the life of an animal in almost everythins satre one small particular. The plant, as a rule, is rosted to a single spot; the animal, as a rule, is free and locomotive.

Yet eren this difference itself is not quite absolute: for there are on the one hand locomotive plants, such as that yuaint microscopic vegetable 258 
tombler, the Hoating green volves, which whirls about yuickly thromgh the water like at living whecel, ly meatus of its rapiel vihratery hatio: and there are, on the other hand, fixed animals, such at the oyster and the seat-intemone, which alle far more rigidly attached to one spot for life than, saly, the common field-orehid or the yellow crocus. For field-orehids and crocuses do travel rery slightly from place to place each season, hy pritting out fresh bulbs of tubers at the sides of the old ones, and springing up next year in a spot a few inches away from their last pear's foothold ; whereats the oyster and the seat-intmonic settle down catly in life on a particular rock, and never stir one step from it during their whole existence. Thus the distinction which secms to most people most fundatmental ats marking off plants form animals-the distinction of movement-turns out on examination to he purely fallacious. There are secientary animals and moving plants; there are herbs that eatch and eat insects, and there are insects that live a life more unerentful and more stagnant than that of any herb in a summer meadow.

Agan, everybody who has studied plants in at broad spirit is well aware that each act of the plant's is just as truly purposive, ats full of practical import, ats any act of all amimal's. If a child sees a cat lying in wait at a mouse's hole, it asks you why she does so; it is told, in reply, and truly told, "Because she wants to eatch her prey for dinner." But even imaginative children seldom or never ask of a rose or a 
marcissus, "Why does it produce this rotel on its petals? Why does it make this curions crown inside the cup of its Hower" ?" 'Those things are thought of as purcly ornamental; ats parts of the plant, not as organs made by it. Fet the rose and the mareissus have just as much a reasom of their own for everything they do and everything they make as the cat of the hind they are just as much governed hy ancestral wislom, though the wislom mat in one catse be cunscions, in the otlier hereditary.

The rose, for example, produces prickles for its own defence, and seented hlosions to attratet the fertilising insects for its own propangation. It does everything in life for some good and sufficient reason of its own, and takes ats little heed of other people's convenience as the tiger or the snake does. "Each species for itself," is the rule of mature; no species ever unilertalkes anything for the sake of any other, except in the expectation of a eorresponding advantage. If the wild thyme lays hy in its throat abundant homey for the bumble-bee, that is hecause it commts upon the bumble-bee to earry its pollen from blosiom to blosion ; if the holly puts forth bright red berries for the robin to eat, that is not because it calles for the robin's distress, hut hecanse it looks. upon the hird as a paid disperser of its stony seeds, and gives him in retum a pittance of pulp for his pains, as sting! payment for the service rendered. The holly and the thyme are confirmed sweaters. Indeed, you will find that 


\section{A Very intelligent l'la:t}

no plant ever wastes one drop more of nectar on its flowers, or one atom more of sweet pulp on its fruit, than is absolutely necessary to secure its own purely selfish object. It offers the bird or the insect the minimum wage for which bircl or insect will consent to do the work it contracts for ; and it never wastes one farthing's worth of useful material on tips or generosities. The rose, for all that poets have saicl of it, is strictly utilitarian. "You help me and I will help you," it sitys to the buttertly; and it liceps the sternest possible dehtor-inde-creditor aceount with all its bencfictors.

As a familiar example of this purposive character in all plant life, I am going, in the present chapter, to take one of the most utilitarian shrubs-the common gorse-and try to show you why it hehares ats it does in the conduct of its affatirs; who help it in life and who hinder it, what friends it strives to buy or conciliate, what enemies it repels hy what violent acts of amed hostility.

Everybody knows gorse; and everghody also knows that it is almost never out of thower. This last peculiarity, however, in (luc to a cause that not ererybody has noticed. We have two distinct kincls of gorse at least_the langer and the smaller. It is the larger sont that one observes most when it is not in blosisom, thomgh it is the smatler kind whose golden hloom contrasts so beantifully in autumn with the rich purple of the upland heather. Now, the latrger gorse hegins to flower in October or November; it goes on oprening its 
buds spasmodically in every fine spell throughout the wintor, reaching its fullest glory of blossom in April and May; while the smaller kind begins to flower in st:mmer, as soon as its larger cousin has ficed its attention on setting seed; and it goes on yellowing our heatls with its wealth of gold till October or November, when the bigger sort once more replaces

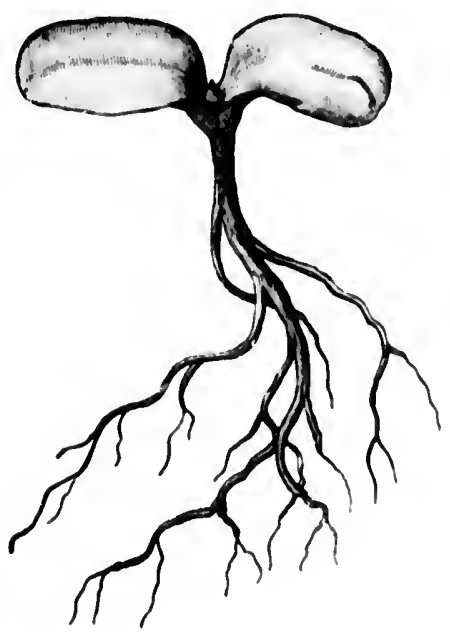

\$

NO. I. THE BABY (inksi: PIANT. it and takes up the rumning. In this way there is no bright day throughout the yearthat is to say, no day fit for insects to gather honey-on which one kind of gorse or the other does not seek to citter for the friendly allies which help it to set its precious seeds, as we shall see in the sequel. It is the larger and hetter-knowng gorse with which I shall cleal chiefly here, though I may oecasionally refer hy way of illustration or contratst to its smaller neighbour.

If we begin at the begimning in the life-history of the gorse, it may surprise you to find that each plant sets ont on its way through life, not as a prickly gorse plant, hut ats a sort of quict and anarmed little flat trefoil. No, I shows you the 
young furze bush in its earliest infantile stage, when it is still essentially a two-leaved seedling. This seedling grows from a small bean scattered by the parent plant in a very curious way, which I will explain lates. Thousands of the beans lie on the ground in erery common, and only at few germinate, under favourable circumstances, into two-leared seedlings, like those representedin these illustrations. The leaves of the first pair spread out flat on the surface of the unoccupied soil and drink in the sunlight. They also drink in, what is equally important to them, the carbonic acid of the air, and manufacture from it the living material of fresh leatres by the aid of the sulllight. For the first few days of its life, the young gorse plant lives mainly on the food laid

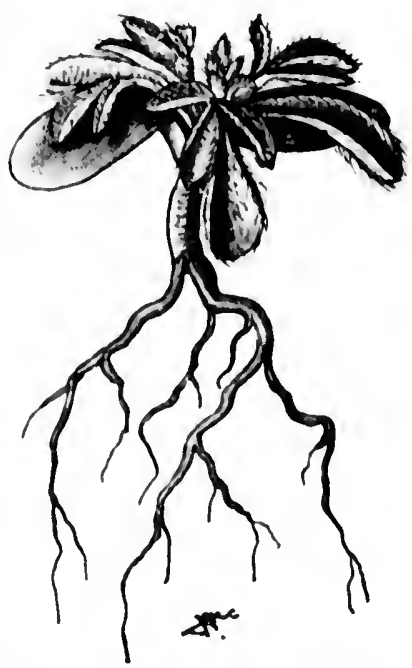

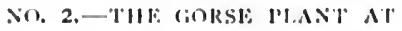
ONF "IFK OI, up for it in the bean by the parent hush; hut ats soon at this is exhausted, and it hats accommlated a little stock of its own by its private exertions, it hegins to mannfacture new leaves and branches that it maty rise alore the tangled mass of competitors hy which its birthplace is surrounded. 
No. 2 show's us this second stage in the young shrub's development. At first sight you would hardly suppose it was a gorse at all ; you might take it for the young of some such allied species at a broom or a genista. You will observe that at this point in its history the young gorse hats trefoil leaves, not very unlike those of some kinds of closer. Why is this? Well, we have many good reasons for supposing that the ancestors of gorse were originally soft-leared and manmed shrubs, like the ornamental genistas which we grow in pots for drawing-room decoration; but ats they were much exposed on open moors and commons, where they were liable to be grazed down and browsed upon by rabbits, sheep, and other herbivorous anmals, the tenderer and more luscions among them stood little chance of surviving. Indeed, so hated is it for plants to grow in such situations, that one not tuncommonly finds tiny trees of Scotch fir, close cropped to the ground, yet with many years' growth exhibited by the ammual rings of wood in their undergromed root-stock. These poor persistent little trees have been nibbled down, year after year, at soon as they appeared, by rabbits or donkeys; yet year after year they have gone on sprouting affesh, at well ats they could, and laying by an ammual ring of woody tissue in buried root-stock.

To some such attacks the ancestral gorses must always have been exposed on the open moors and hillsides of primitive Europe, at first, no 
doubt, from deer and wild oxen and beavers, but later on from the sheep and cows and goats and donkeys which followed in the wake of aggressive civilisation. Under these circumstances, most of the soft-leaved and umprotected plants got eaten down and killed off; but any shrub which showed a nascent tendency to develop stout spines or prickles on their hranches must have been favoured by mature in the struggle for existence. The consequence was that in the end our upland slopes and open spaces all over Western Europe came to be ocenpied by nothing but strongly armed plants - brambles, thistles, blackthorus, maty-bushes, nettles, butcher's-broom, and the various kinds of fur\%, all of which can fold their own with ease against the attacks of quadrupeds. Indeed, there is one not mecommon English herb, the little purple-flowered restharrow, which very well illustrates this curious connection between the production of thorns and the habit of growing in much - browsedover spots; for when it settles in enclosed and protected fields it produces smooth and nuarmed creeping branches, but when it happens to find its lot cast in places where clonkeys and rabbits abound, it defends itself angiust the dreaded encmy by covering its shoots with stout woody prickles.

Still, to the end of its daty, the developed gorse plant never entirely forgets that it is the remote descendant of trefoil-bearing ancestors; for not only does every young gorse begin life with trefoil 
foliage, but if frost happens to check the growth of the budding branches in the full-grown bush, or if fire singes them, the shrub at onee puts forth a

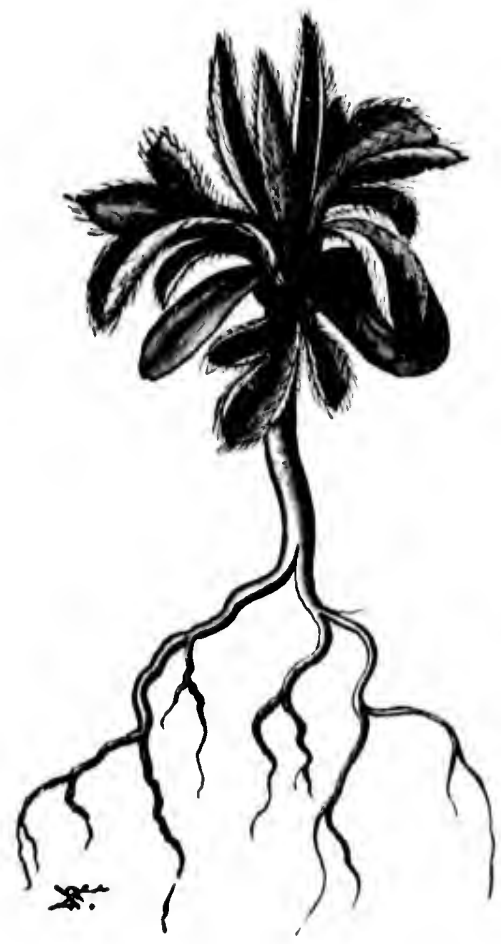

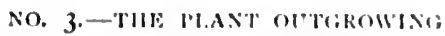
It's rklitil. Slagk. short sprout of trefoil leares at the injured point, ats thongh reverting in its trouble to its infantile nature.

In No. 3 we see the thirel stange in the upward evolution of the baby sorse. Here, the see lling bergins to outgrow its childish trefoil stage, and to prepare itself for the repellent prickliness of its armed manhood. Yoll will observe in this catse that the onter and lower leaves have still three leatlets apicec, but that the upper and inner ones -that is to sity, the youngest and latest produced - have the form of single long blades, like those of the broom bush. As yet, these solitary leares are also matrmed : they do not end in sharp points like the later foliage, and they cannot pierce or wound the tender noses of 
sheep or rabbits. But if the gorse were to contimue long in this manmed condition, it would stand a poor chance in life on its open hillsides ; so it soon proceeds to the stage exhihited in No. t. This illustration shows you a plant about a fortuight or three weeks old, with trefoil leaves below, passing gradually into silky and hatiry single blacles, which in turn srow sharper and thinner as they push upward towards the unoceupied space above their native thicket. Interspersed among these sharp little leaves you will also mote a few grooved branches, eats ending in a stout prickly point; these prickles ate the chice defence of the busle against its wateliful enemies.

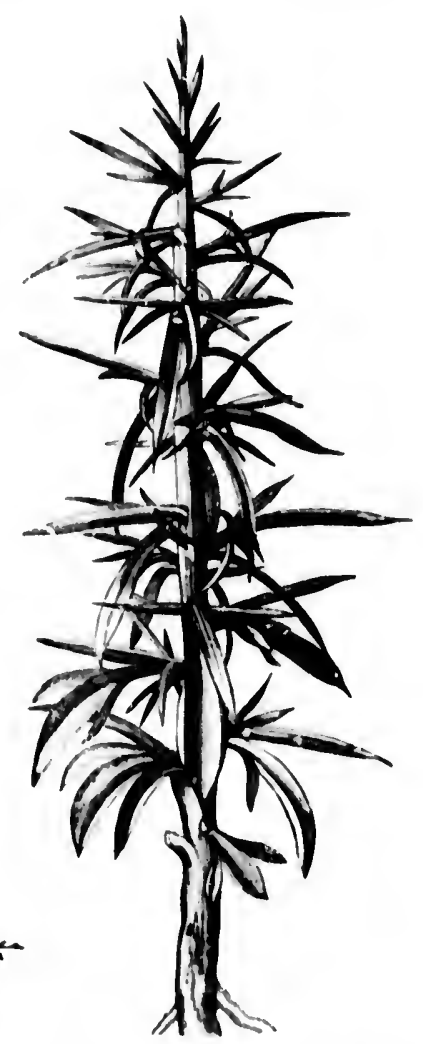
But the leaves and the branches are often so

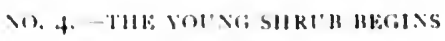
(1) AKU IISFIJ much alike that only at skilled botanist ean distingush the one from the other. Both are shatp and intended for defence; 
and as the branches of gorse are green like the leaves, both perform the same feeding function.

In No. 5 I have chosen for illustration and comparison a full-grown shoot of the common-

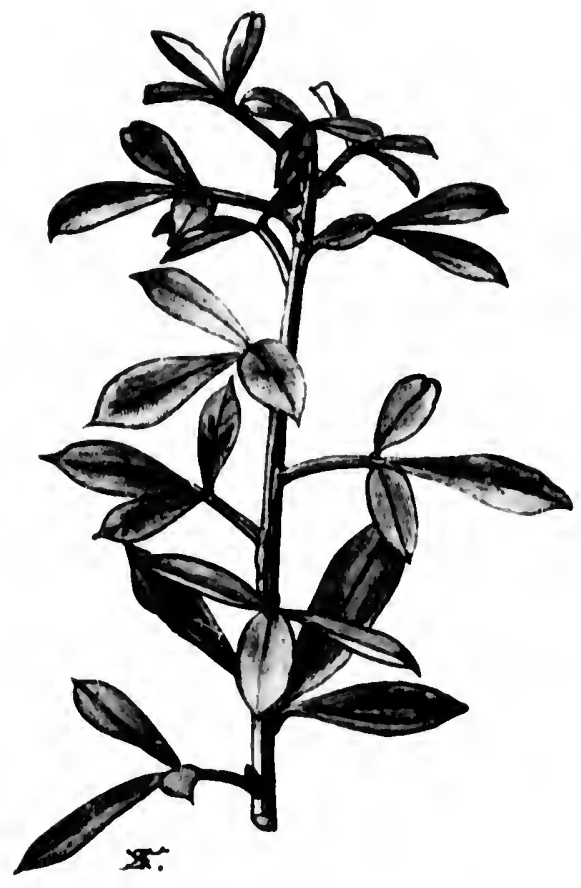

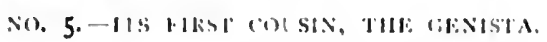
scented yellow genista, so often grown in pots ats a table decorattion. 'This pretty' shrub hegius in life so much like at gorse-bush, that if 1 were to show you very youthful secdlings of both, you could hardly discriminate them. That is to say, in all probability, both are descendants of a common ancestor which hat trefoil leaves and bright yellowpeaflowers. But the seented genistats happened to find their lot cast in inacessible places, on cliffs or crass, where defence against browsing animals wats paractically monecessary; while our ruder northers gorse had its lines laid on rough upland moors, where erery passing beast 


\section{A Very Intellaglent Plant}

could take a castlal hite at it. The gorse was, therefore, driven perforec into producing thorny branches which would repel its foes, while the genista retained the old soft silky shoots and broad trefoil foliage.

Broom, which is a close relation of both these plants, with much the same yellow peatlowers and hatiry pods, oecupies to some extent an intermediate position between the two types. The young shoots have leaves of three leatlets, ats shown in No.6; hut the older hranches are covered with leates of a single leaflet apiece, like the second form produced by the gorse plant. 'The trefoil leares of the broom also closely resemble those of the laburnmm, which

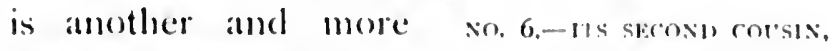
tree-like descendant of

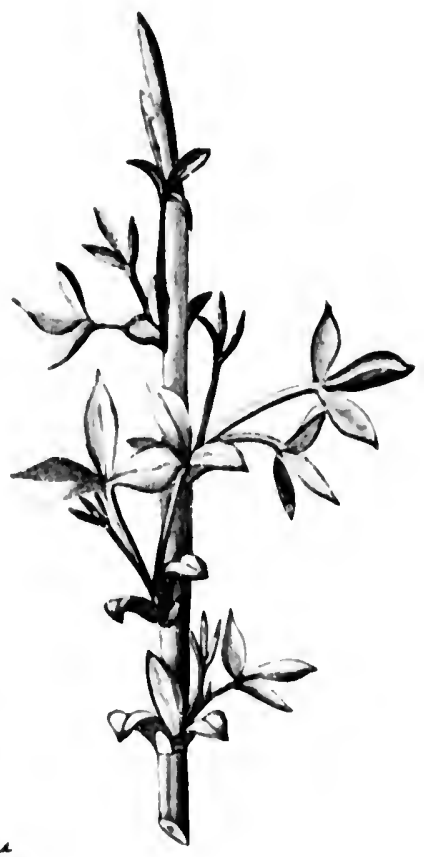
the same ancient ancestor, with similar yellow hlossoms, and pods and heans of much the same chatacter. It is inferesting to observe in a family of this solt how the young seedlings ane in every case almost identical, 
and how, as they approach maturity, they hegin to assume the alult differences which matk off each later developed kind from the primitive and central form of its ancestors.

But is sorse really exposed to the attacks of animals? Would any herbivore calle to eat such hatrd food? If

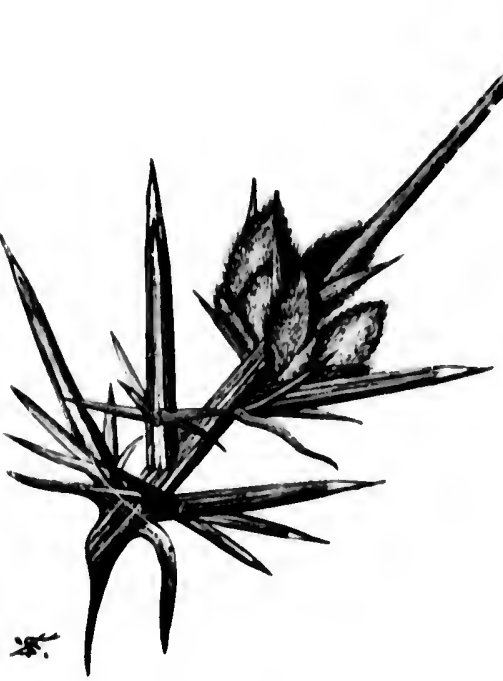
HROWSINI ANIMAI.S.

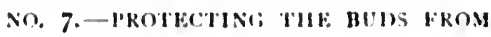

you dombt it, you have never lived neate a gorse-clat commmon. linom the monent the secelling shows itsclf above the ground it is ceatselessly mibhled at by rabbits and other rodents; and even after it lats acyuired it: prickly armour, it matkes excellent focleler, if only the sharp tops citn be rendered barmless to the sensitive noses of cattle or donkeys. Gipsics know this fact well; and you maty often see them on our Surrey hills cutting the succulent young hanches and chopping them up fine in a wooden trough till the prickles are destroyed. 'Their horses then eat the good green food most greedily. 
The gorse knows the same thing, for); and it takes particular cate to preserve its leases and flowers agamst the aggersive yuadrupeds. When Nosember connes it hegins to hlossom. No. 7 shows you how eleverly and cautionsly it makes its preparations for this important functions. The flower-hucls, I need hardly saly, are particularly rich and juicy, and, therefore, particusarly liable to the assiultts of the collens. Hence, you will observe, they are dombly protected. Toguatdanganst lange amimals, eatch little knot of huels is catrefilly placeed, forsatiety, in the angle formed by the main stem with oine of its st:ont, stout branches. Stem and branch alike end in a forbickling prickle, and the buds are so

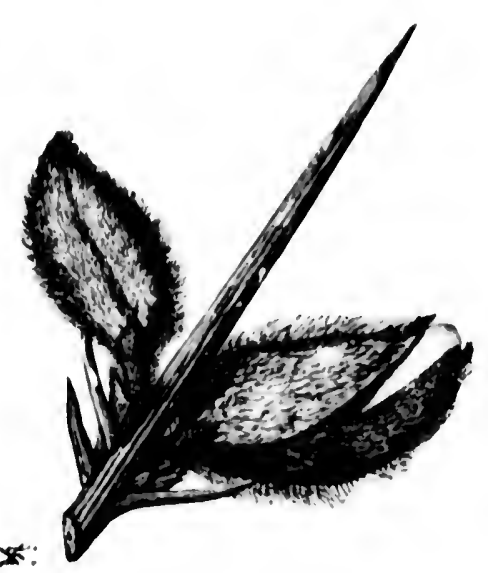

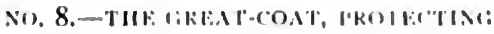

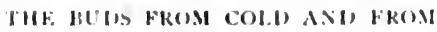

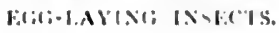
set in the axil that it is simply impossible for any howsing creature to get at them without encomblering both these serious weapons. Indeed, no illustration can fully bring out the beantiful variets and complexity of arrangement by which each separalte gromp of huds is completely defended; in order to molerstand it fully, I advise you, after reading this chapter, to go 
out to the nearest common, and examine a flowering gorse-bush for yourself, when you will see how wonderfully and how intelligently the plant provicles for the equal security of all its blossoms. I do not wish to be personal, but if for one moment you can imagine yourself a donkey, and try to help yourself with your teeth to some of the juicy buds, you will find that it is practically impossible to do so without receiving a whole array of serried lance-thrusts from several separate prickles.

But large animals are not the only foes against which the gorse has to defend its blossoms. It is almost equally exposed to the unfriendly attentions of flying insects, which desire to lay their eggs near its rich store of pollen and its soft yellow petals. To ward off these winged assailants, mere prickles are insufficient. The insect can wriggle in sideways, and so deposit its egg, which would develop in time into a hmigry grub; the grub would proceed to eat up the flower, and thus defeat the object which the plant has in view in producing its blossoms. No. 8 shows you how the gorse meets this second difficulty. It covers up the buds with its stout calyx, which, for greater security, is reduced to a pair of sepals only, though in allied types there are five, and traces of the five still exist in the lobed top of the existing calyx. This onter coverlet, or greatcoat, is thickly sprinkled with a sort of fur, composed of dark brown hairs, which baffle the insects, and prevent them from laying their eggs upon the surface. Indeed, nothing 
keeps off insects so well as hairs; they form to these little creeping creatures an impenetrable thicket, like tropical jungle to an invading army. Ants, you will remember, cannot creep up stems which are thickly set with hairs; and in warm climates, people take advantage of this peculiarity by wrapping fur round the legs of meat-safes, so as to keep off those indefatigable pests of the equatorial housekeeper.

Nor is this the only use of the short brown hairs. I spoke of the calyx above as a great-coat, for warmth is really one of its chief objects. It keeps off the cold as well as the insects. You must remember that the greater gorse is a winter-fowering plant : it lays itself out to attract the few stray bees which flit out in search of food on sunny mornings in December and January. A bush with this habit needs protection for its bucks from the cold: just as you see the crocus does, when it wraps up its flowers in a papery spathe, and as the willow does when it encloses its catkins in soft, silky coverings. The hairy coat of the gorse bud has just the same function: it is there for warmth as well as for protection against egg-laying insects. That, I think, is the reason why the hairs are coloured brown ; because brown is a good absorber of heat; the fur collects and retains whatever warmth it can get from the winter sun in his friendlier moments.

You will further observe in the illustrations, and still better on the living gorse-bush, that all the buds are not at the same stage of development 
together. The plant does that intentionally. It is a slow and gradual flowerer. The reason is plain. Our winter and spring are proverbially uncertain. The bush does not want to put all its esess into one hasket. Sometimes, in doubtful weather, a few of the hucls derelop up to the staige shown in No. 8 , and are just ready to open. Then eomes a frost, a killing frost, and nips them in the bud, more literally than we often mean when we use that familiar metaphor. In such cases, you will sometimes find the more advanced flowers are killed off and never develop further. But look behind them in No. 8, and you will see that the bush holds in reserve a number of younger buds, against this very contingency. They are wrapped up tight in their warm hrown overcoats, and they keep one another warm as they nestle anainst the stem; so that however sharp the frost, they seldom suffer, in England at any ate. Beyond the Rhine, where the winters are severer, both buds and foliasse would be nipped by the east wind; and so the smaller gorse is contined to the portion of Europe west of the Rhineland, while even the greater kind cannot live in Russia. To eastward its place is taken by hardier shrubs, which have still more special methods of protection asainst the severe weather. In Western Europe, on the other hand, the buds are so arranged that in spite of frost we get a constant succession of gorse-blossoms from November to May or June, when the running is taken up by the smaller summer species. Thus the bees are never deprived of gorse-blossom. 
and kissing, as the old saw says, is never out of fashion.

1 have said above that gorse protects itself against flying insects. But not indiscriminately. It is a respecter of persons. While it wishes to keep off the egs-layings and flower-gnawing types, it wishes to attract and allure the honeysuckers and fertilisers. For this object alone it produces its bright yellow petals and its delicious, nutty perfume, which hangs so sweetly on the air in warm April weather. And l know few things in plant life more instructive and interesting to observe than the way of a hee with this flower. Go out and watch it, and verify my statements. When the blosiom first opens, it looks somewhat as in No. 9, only that the keel, as we eall the lower pat of the flower, is not half open, as there, but firmly locked together above the stamens on its mper edges. This keel, as you may note in No. I o, ccnsists of two petals slightly joined together at the margin. On either side of it come two other petals, which we call the wings, and which are fitted with a funny little protuberance at their hase so arranged that it locks the whole lower part of the blosisom together. This mechanism cannot be seen in the illustrations, nor indeed can it be properly understood except in action; but gorse is so miversal a plant that most of my readers can ohserve it and examine it for themselves at leisure. The upper petal of all, known as the standard, has no special duty to perform save that of advertisement. It attracts 
the insects, and show's them in which direction to approach the flower.

Now comes the strangest part of the whole process of flowering. When the bee settles on the blossom, she alights on the keel and wings, to which she clings by her fore-legs, and so weighs down the entire lower portion of the mechanism with her weight. As she does so, the clasps

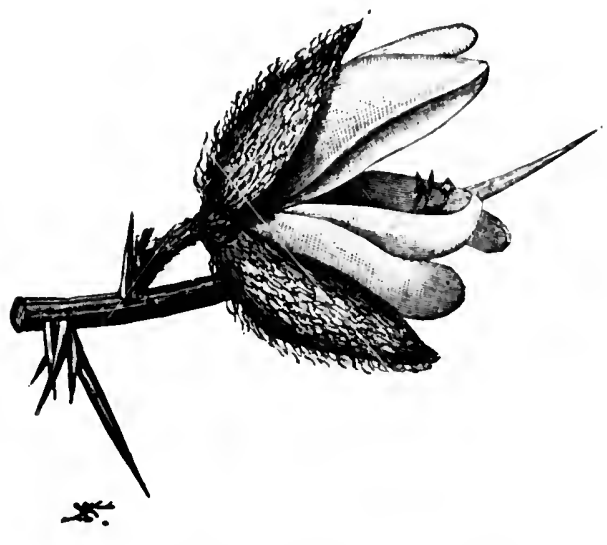

No. 9. - THE FIOWER, HALF OPENED. or knobs on the wings come undone, and the whole flower springsopen ela. stically, as you see it in No. ro, exposing the stamens and the young pod which form its central organs. At the same moment, the pollen, which is specially ar-

ranged for this contingency, bursts forth in a little explosive cloud, covering the boty and legs of the visiting insect. She takes no notice of this queer manceuvre on the part of the plart, being quite familiar with it, but goes on helping herself to the store of honey. As soon as she has rifled it all, she flies away, and visits a second flower of the same kind. In the act of doing so, she rubs off on its sensitive surface the pollen with which the 
last blossom dusted her, each part heing so contrived that what she takes from one flower she hands on to another. Yon can see the little tufted stigma standing up in the centre of $\mathrm{No}$. 10, and can understand how it must catch on its tip the fertilising yellow grains which the bee collected in a previous explosion.

But now notice a curious thing that next happens. When once the flower is "sprung," as we call it-that is to saly, thus elastically opened - the keel and wings never go back again into their original position. They

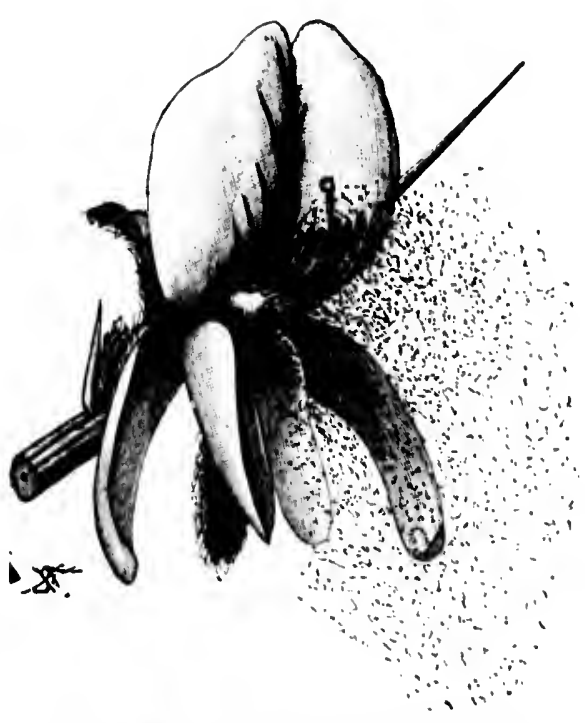

NO. 10.-THE Flow I)ISCH.IRGING IULI.EN.SHOWLRS.

comprehend that there is a grealt cifference between the virgin flower, in which the keel and wings are locked over the stamens, and the "sprung" one, in which the keel and wings have deseended from their first position so that the entire centre of the blossom is exposed to view. Moreover, after the flower is once ferti- 
lised, it produces no more bribes for the bee; it has got all it wants out of her, and it is certainly not going to find her in food and pay her wages for nothing. The consecpuence is, that a "sprung" flower becomes, as it were, an advertisement to the bee of "Nothing to eat here." If you wateh a bee paying her visits to a gorse-bush, you will find that she passes by the "sprung" flowers without the slightest notice-seems, in fact, oblivious of their existence; but she fastens at once on each virgin flower, and promptly-though, of course, unconsciously-fertilises it. Such a device for showing the visiting insects antomatically which flowers are fertilised and which are not is, naturally, a great saving of time; and plants which develop such devices gain such an advantage thereby as neither they nor the bees are slow to appreciate. In some cases, as seen, as soon as the blossom has hegnu to set its seeds, it changes colour as a sign to the bees and butterflies that it is no longer open to receive their visits; in others, the petals fall the moment fertilisation is effected, and so the flower ceases to be at all conspicuous.

In the gorse-bush, the petals, however, do not fall at all. They remain to enclose the young pod as it swells and clevelops. The reason for this divergence from the usual habit of plants is, I think, because the gorse-bush flowers and ripens its fruit in such very cold weather, that the young and tender pols need all the cover they can get at the moment when they begin to swell and to go 
through the important process of fructification. The calyx and the petals help to keep things wam for them, and so they persist till the pods are ready to open and clischarge their beans.

Each pod contains as a rule four beans, and these are fat and well stored with nutriment for the baby seedling. The young plant subsists for its first few days on the nourishment thus laid by for it ; for gorse is not one of those improvident plants which turn their young ones loose upon a cold and unsympathetic world without a coin in their pockets, so to speak, to fall hack upon. Plants in this respect differ, like human beings. Some send their offspring out, mere street arabs of the vescetable workl, without any capital to live upon; others provide them with a sood stock or reserve of foodstuff which suffices them till they are of an ange to earn their own living. You can judge by the fatness and distention of the pod in No. I I that the young beans of the gorse are fairly provided for in this respect. Indeed, so rich are they in food, that they would suffer seriously from two setis of enemies, were they not protected against both exactly as the buds are. The stout prickles at the ends of the branches efficiently repel the assaults of browsing animals; the close hairs on the pods (not seen in the sketch; just as efficiently repel the insects which would fain lay their esgss in the heans, as one knows they do in the similat catse of the edible peats in our garden.

Nothing is more beatutiful about the gorse, 
indeed, than the soft, close covering of fur in the young pods, which gives them almost the appearance of miniature ducklings. No insect can penetrate it; and if only the first few days pass by without serious mishap, the gorse may count upon maturing its seeds in peace and quietness.

They ripen in the first basking warmth of July, or often earlier. As soon as they are ready for dispersal, the bush

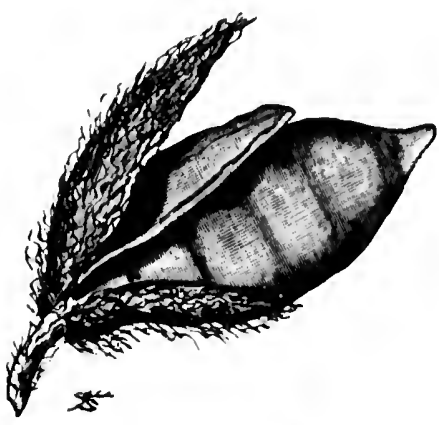

N1). II.-TIE POD, WITH THE BEANS WITHIN IT. has a device for scattering them and sowing them in proper places for their due germination, which is quite in accordance with its other proceedings. Gorse, indeed, is a very explosive species. It knows the full value of the propulsive habit. The valves of the pods remain straight and rigid after the beans have ripened; but the sides contract, only the ribs or thickened edges keeping them extended in their places. At last, on some very sunny morning, the baking heat dries them up to such a point that they can no longer hold together. They curl up suddenly and violently, as you see in No. I 2, and expel the beans, shooting them out like little bullets all over the common. If you happen to sun yourself on a gorse-clad 
moor on such a warm summer morning, you will hear, from time to time, little abrupt discharges as if a succession of toy pistols were being continually fired off in the thicket all round you. These noises are due to the bursting pods of gorse, which go off one after another, and shed their seeds piecemeal over a considerable area. Should you look in early spring on the bare spots around a moor or common, you will find gorse seedlings by the thousand, all fighting it out amo.ng themselves, and all trying their hest to occupy the meovered

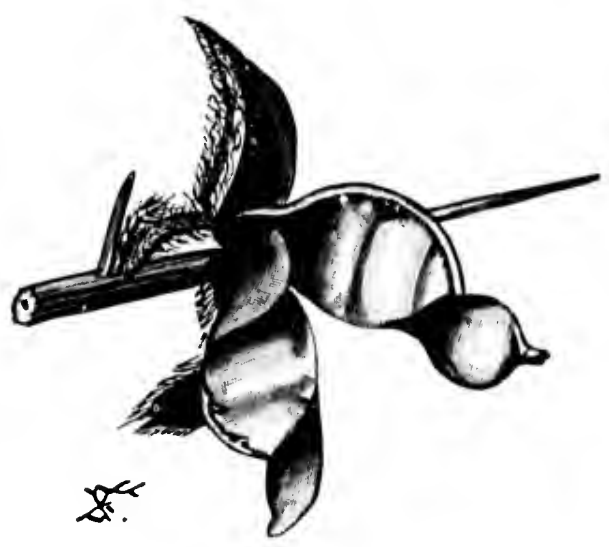
NO, I2.-THE P(H), AFTFR MISHARGING; TIE BLANS BIASTITAIIY.

spaces in the neighbourhood of their parents.

And here the wonder of their lives begins all over again. For while the gorse was old and woody, it grew like gorse, all stern and prickly. But as soon as the young seedlings start afresh in life, they seem to forget their parents: they revert once more to the old trefoil condition. All young plants and animals, at leatst in their embryonic stages, show this strange tendency to throw back 
at first to the ancestral form; and it is fortunate for us that they do so, for it often enables us to perceive molerlying relationships which in the adult form escape our notice. Nobody who looked at a furze-bush in its stiff and prickly old asge would ever suspect it at first sight of a cousinship with elover. Yet when we consider the trefoil leaves of the seedling, and the shape of the separate peatlowers in the adult form, we can see for ourselves that the two plants are far closer together than we might be tempted to imagine. Indeed between the little creeping yellow clovers and the angressive furze or the tall and heatiful laburnum, we can find even now a regular series of connecting links which show clearly that all alike are slightly divergent descendants of a single common ancestor.

We may conclude, then, that sorse in every particular lays itself out in life to fight its own battle, and to meet the peculiarities of its special situation by its own exertions. Born a trefoilbearing plant, muarmed and undefended, it produces spines instead of leaves as soon as its growth exposes it to the attacks of enemies. It clefends its buds alike from the attacks of cattle and the assaults of insects; it wraps them up from the cold in efficient overcoats. It cares for its young and lays up food in its beans on their account; it scatters its seed upon moccupied spots where they may stand the best chance of picking up a living. All these acts ale analogous to those produced by intelligence in animals; and though the intelligence 


\section{A Very Intelligent Plant 283}

is here no doubt unconscious and inherited, I think we are justified in applying the same word in both cases to operations whose effects are so closely similar. Gorse, in short, may fairly he called a clever and successful plant, just as the bee may be called a clever and suceessful insect, because it works out its own way through life with such conspicuous wisclom. 


\section{II}

\section{A FOREIGN INVASION OF ENGLAND}

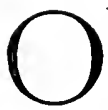

UR worst enemies are not always the most apparent ones. It is easy enough to build forts for the protection of our towns and harbours against French or Germans, but it is very difficult to devise means of defence against such insiclious foreign invaders as the influenza germ or the Coleraclo beetle. France lost much by the war with Germany, but she probably lost more by the silent onslaught of the tiny phylloxera, which attacked her vineyards-attacked them, literally, root and branch, and paralysed for several years one of her richest industries. Yet invasions like these, heing less obvious to the eye than the landing of a boat-load of French or German marines on some bare rock in the Pacific claimed by Britain, attract far less attention than aggressions on the Niger or advances in Central Africa. The smallness of the foe makes us overlook its real strength - it has the force of numbers. We forget that while we can exterminate hostile human hands with Armstrongs and torpedo-boats, the resources of civilisation are still all but powerless against the potato blight, the vine disease, and the destroying microbe. 
The enemies of our corn crops in particular are many and varions. There is the wheat-beetle, for example, which ravases the wheat-fields in two ways at once, the grub devouring the growing young leaves, while the perfect winged insect eats up at leisure the grain as it ripens. There are the various cockchafers, which vie with one another in their cruel depredations on the standing corn. There are the skip-jacks and wire-worms, and other queerly named beasties, which attack the roots of the plant underground. There is the corn salw-tly, whose larva feeds on the stalk of rye and wheat, till it fhally cuts off the whole hamin altogether close to the soil at the lottom. There are the midges which lay their eggss in the swelling eatr, where the magsots develop and prevent the proper growth of the impregnated grain. There is the gout-fly, which causes a gouty swelling at the joints, and the corn-moth, which cevours the stored wheat in the granary. There are the redmaggot, and the grain-aphis, and the thrips, and the daddy-longlegs, all of which in various ways prove themselves serious enemies of the agricultural interest. And there are dozens more known only to men of science by dry Latin names, and duly chronicled by the farmer's friend, Miss Ormerod, in many learned and exhaustive monographs.

But as if these were not enough for our "depressed" neighbours, the agriculturists, the last ten years or so have seen England invaded by a foreign foe, either from Germany or Americaa foe whose life-history has been made a special 
subject of study by my collaborator, Mr. Enock, and whose strange story I shall detail (largely from his materials) with no unnecessary scientific verbiage in this present chapter.

The new invader is called the Hessian fly; and he made his first appearance in Britain, or at least first attracted official entomological attention in this country, in 1886. If he was here earlier, he skulked incognito. For more than a century, however, he had already been a great scourge in America, where he first acquired the name of Hessian fly during the revolutionary war, through the popular belief that he had been imported from Europe into Pennsylvania by the Hessian troops employed as mercenaries by George III. in his fruitless struggle against the revolted colonies. The Hessians were the betes noires of the patriotic Americans; and the farmers, finding their crops devastated by a pest till then unknown, came at once to the conclusion that their enemy, King George, had sent the two plagues, human and entomological, over sea together. They regarded the question much in the same spirit as that of the loyal poet in the "Rejected Addresses," when he asks about Napoleon, "Who fills the butchers" shops with large blue flies?" The Briton set down every natural misfortune to "the Corsican ogre"; the American set down all evils that befell him to the Rhenish mercenaries.

Ever since that day, much controversy has raged in America and Germany as to the original home of the destructive creature. One school of dis- 
putants hotly mantains that the Hessian fly, which now abounds in parts of France, Austria, and Russia, is a native of the Old World, and that its first home conncided with that of our primitive cereals, Southern Europe and Western Asia. Another school, anxious to make ont the enemy an American citizen, fights hard for its being an aboriginal inhahitant of the Uniter States. Thus much, at least, is eertain, that at the present day the "fly" is found in both hemispheres in too great abundance, and that in America in particular in certain disastrous years it has almost ruined the entire wheat crop. I have seen whole fields upon fields there simply pillaged hy its rarages. The loss produced by this insignificant little creature, indeed, has in some seasons been measured by millions of pounds sterling.

If you go out into a harley-field in England where the Hessian fly has effected his entrance, you will probably find a large number of plants of barley, like that delineated in No. I, with the stem bent down sharply toward the ground at the second joint. At first sight you might imagine these stalks were merely broken by the wind or fallen by their own weight; hut if you examine them closely in the neighthourhood of the bend, which occurs with singular unanimity in all the affected plants at about the same point, you will find insicle the sheath of the blade, where it encircles the stem, a curious little body which the farmers with rough eloquence have agreed to describe as a "flax-secel." If you watch the 
development of the "Hax-seed" again, you will find that it is not a seed at all, but the pupacase (or rather the grub-shell) of a small winged insect; and it is the life-history of this insect, the Hessian fly, that I now propose to sketch for you in brief outline.

No. 2 shows the mother Hy herself, very much enlarged, for in nature she is but a small black gnat, belonging to the same group as our old

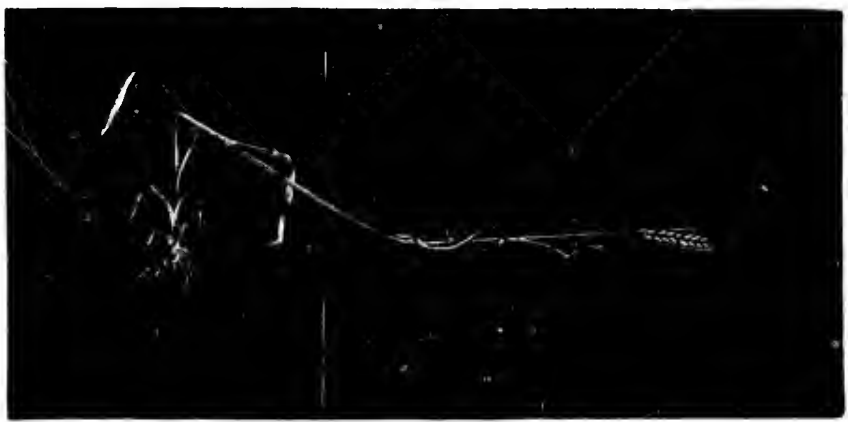

NO. I.-AN INVAIII RARI.EY PLANT.

friend (and foe) the mosquito. You will observe that she is a fairy-like creature, for all her wickedness: she has two delicately fringed wings (with "poisers" behind them), a pair of long antenna with beaded joints, six spindle legs, and a very full and swollen body. She needs that swollen body, for she is a mighty egg-layer. Sine flies about on the stubbles in September, and lays her eggs on the self-sown barley plants and on the aftergrowth of the cut crops; as well as in spring 
(a second hrood) on the new sprouting barley. One industrious female which Mr. Enock watched when so employed laid no less than i 58 eggs on six distinct plants; while another laid eighty on a single leaf. He has noted in cletail many cases in the same way, and all show an astonishingly high level of matiority. The eggs are extremely minute, and are pale orange in colour, with reddish clots. Most of them are deposited on the leaf itself, or on the sheath or tube which forms its lower portion. And now see how clever this dainty little creature

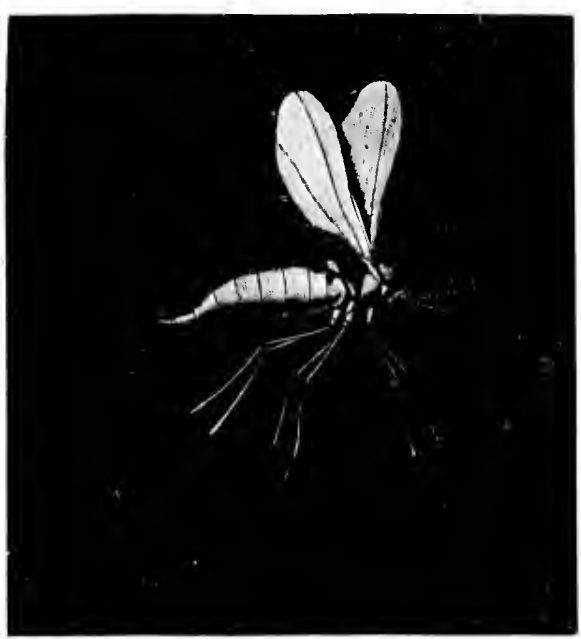

NO, 2. -THE SOURCE OF THE MISCHLF : THE HESSIAN HIY.

is ! She lays

her eggs with the head end downward; and as soon as the tiny grub hatches, which it cloes about the fourth day, it emerges from the shell, and walks straight down towards the stem, at the point where the protecting leaf-sheath is wrapped closely round it. The worm forces itself in between the stem and the sheath, and after 
walking steadily for four hour's, at the end of which time it has covered a record space of nearly three inches, it arrives at the joint, where the sheath begins, and so finds its way blocked by the partition wall; it can get no further. Here

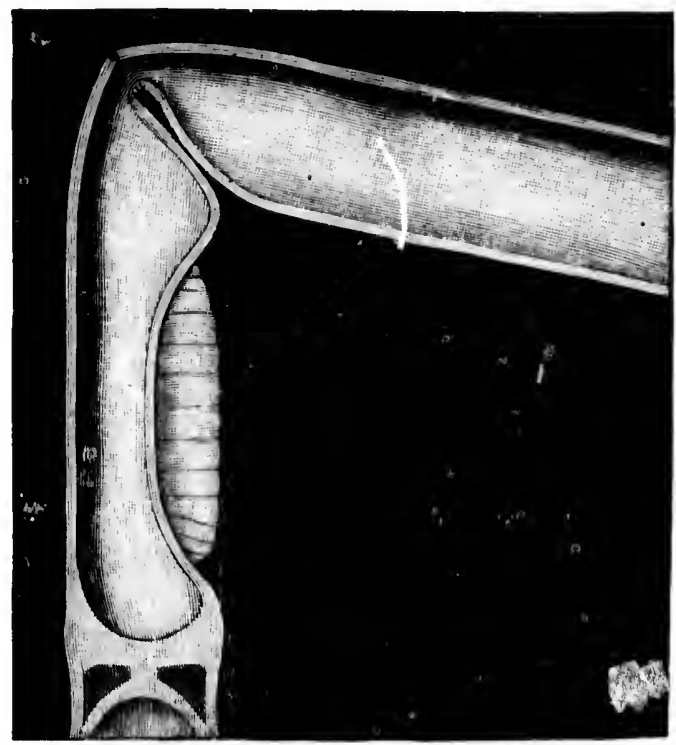

NO. 3.-THE GRUR AT WORK.

then the young grub stops, as you see in No. 3, wedged tightly in between the leaf-sheath and the stem, and with its head pointing downward. Being a hungry, and therefore an industrious creature, it at once sets to work to eat the barley-plant. This it does by fixing its sucke:-like mouth on the 
soft, sweet, and juicy portion of the stem just ahove the joint-that same soft, sweet, and juicy portion which children love to pull out and suck, and from which the grub, too, sucks the life-juice of the barley-plant. Naturally, however, you can't suck a plant's life-blood without injuring its growth ; so, after a very short time, the enfeebled stem hegins to bencl, as you see in No. 3, a little distance above the point where the grub is devouring it. It has been undermined, and its vitality sapped, so it gives way at once near the source of the injury.

How much clamage this action cloes to the crop you can best understand by a glance at the two next contrasted illustrations. No. + represents "seven well-favoured ears" of barley, unaffected by Hessian fly, and with the grains richly filled out as the farmer desires them ; No. 5, on the contrary, shows you "seven lean ears," attacked by the fly, and bent and rumed in various degrees by the indirect action of the silently gnawing larva. Look on this picture and on that, and you will then appreciate the British farmer's horror of his insignificant opponent. You will observe, by the way, that I speak throughout of barley, not of wheat. This is because in England, where these sketches are stuclied, the time of wheat-sowing is such that the wheat has so far escaped the pest; the female flies are all dead before the crop is sprouted: whereas in America the "fall wheat" comes up at the exact moment when the female Hessian fly is abroad and scouring the fields in search of plants on which to lay the eggs of her 
future generations. In England, therefore, it is barley alone which is largely attacked; and since barley is mainly used for malting, to make beer or whisky, the teetotaler may perhaps reflect with

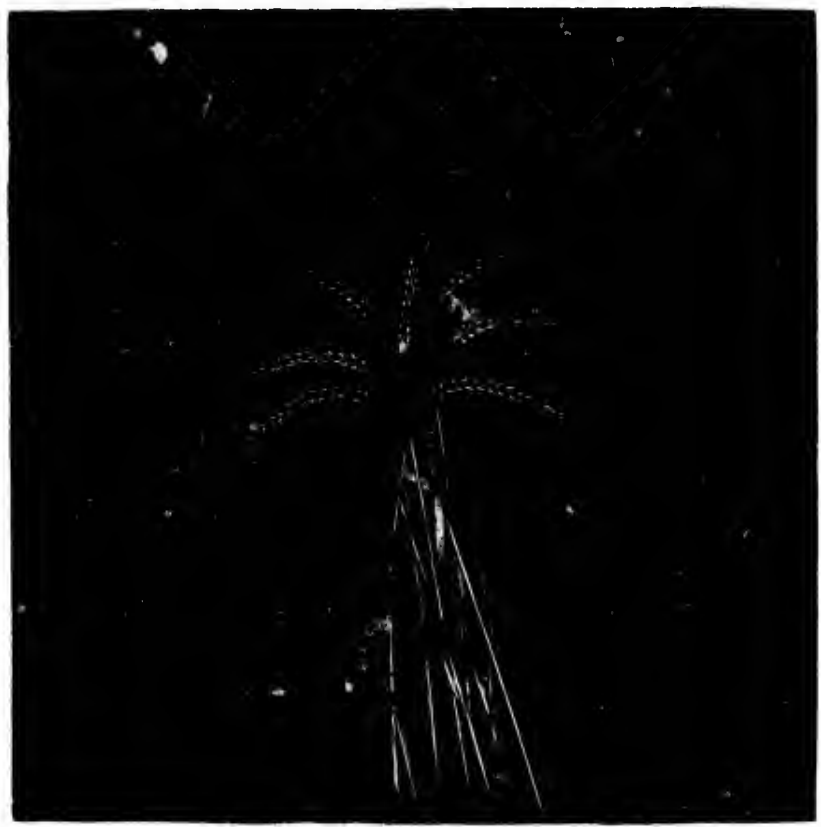

NO. 4--SEVEN WEI.L.FAVOURED.FARS, INATTACKED.

complacency that the fly is merely playing the game of the United Kingdom Temperance Alliance. His joy, however, is fallacious, for, on the other hand, if we don't raise enough barley at home to brew our ale, we don't on that account refrain 
from malt liquors: we buy it from elsewhere; so that, in the eyes of the impartial political economist at least, the Hessian fly in Britain must be regarded as an ummitisated national misfortmne.

The grub eats and eats, in his safe cradle between the sheath and the stem, till he is ready to pass

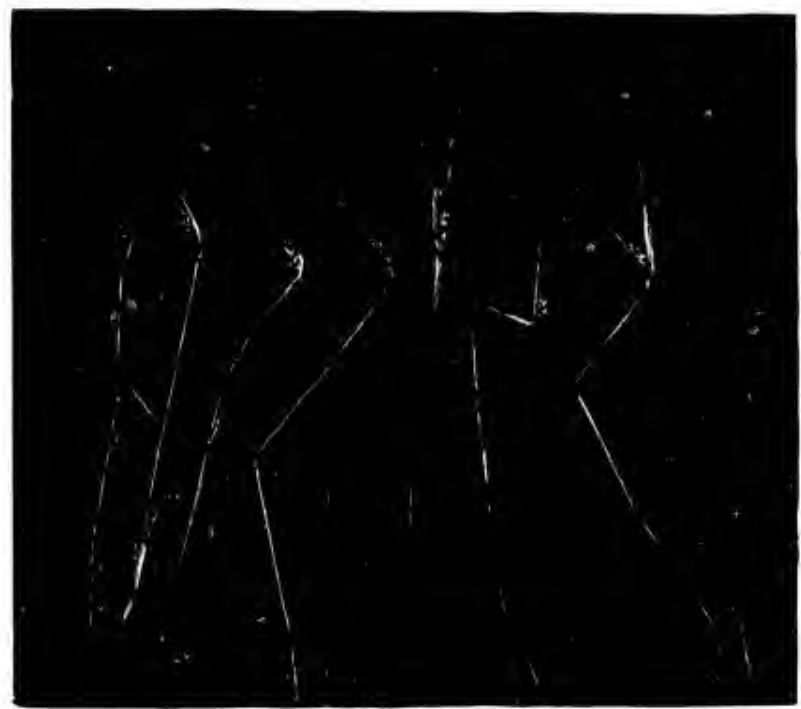

NO. 5. -SFVEN I.EAN EARS, AI'TACKEI BY GRUBS.

into the adult condition. But he does this by various and complicated stages, all of which I do not propose to set forth in full with the tedious minuteness of a scientific treatise, lest I weary that fastidious and somewhat lay person, the "general reader." It must suffice here to say, in brief, that 
the larva is at first soft and free, but that before becoming a true pupa or chrysalis he passes through an intermediate encased or "flax-seed" stage, in which he performs some curious evolutions. The young larva when he starts in life is whitish or yellowish; in the "flax-seed" stage he becomes a rich chestnut brown, and seems externally quiescent. But the fact is, he arrives at full growth in the white form, and then leaves off feeding; his skin now hardens and darkens, and he looks from outside very much like a pupa. Indeed, his outer covering is now a sort of solid pupa-case, in slyape just the same as the original grub, but more sombre in colour. No. 6 shows you the portrait of the grub in this curious intermediate conclition. If you compare it with No. 3, you will see that the outer skin still preserves the original shape of the fat young larva; but that the enclosed grub himself, here shown as if the case were transparent, has shrunk away from his own old skin, just as a ripe nut shrinks away from its shell, to borrow Mr. Enock's admirable phrase for describing the process. And this strange shrinkage is connected with a very curious fact in the eventful life-history of the Hessian fly; it tells us of a problem which the grub has to face, and for which it has devised a most unexpected solution.

You remember that the young maggot had necessarily to work its way head downward along the stalk, in order to fix itself in the only place where it can find the soft food needful for it, between the sheath and the stem, where the tissue 
A Foreign INTASION OF ENGLaNi) 295

is tenderest. But when it emerges later on in the open air as a fly, it has to walk back again to the outer world above the joint; and this it conld not do if it had still to go head downward. Yet there seems no room for it to turn in. Somehow or

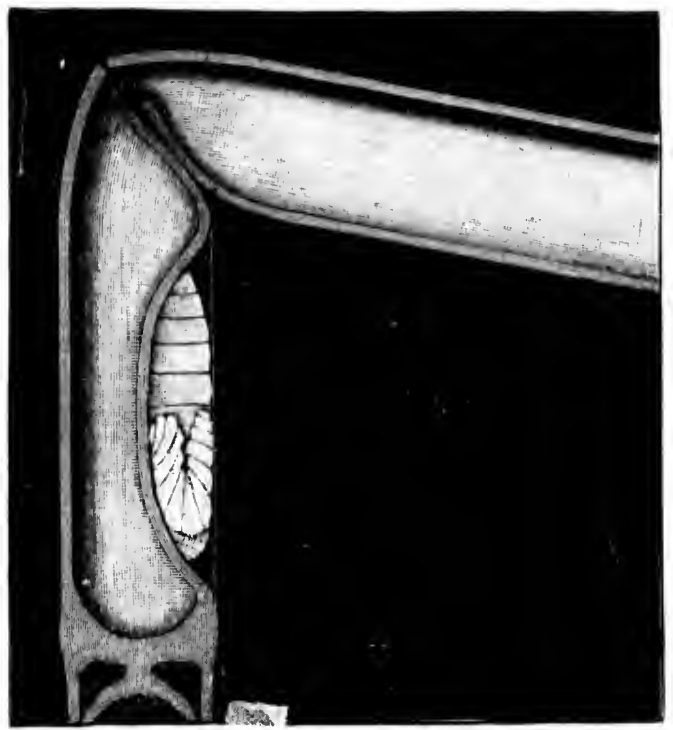

NO. 6.-THE GRUB TURNING; RUUND INSIDE ITS OWN SKIN.

other, in that restricted space, it must reverse its position; it must get itself head upward. How is it to do so? This difficulty early struck Mr. Enock in his examination of the creature's life; and with characteristic patience he determined to investigate it. His researches not only answered 
the question itself, but also discovered a meaning and purpose in a certain organ of the adult grub, the nature of which had heretofore been a standing puzzle to that section of society which interests itself prominently in the Hessian fly question. The larva in its "tlax-seed" stage develops an odd and very hard organ, known as "the anchor-process," near the head; and this "anchor-process," as Mr. Enock has shown, is used by the grub to turn it round completely within its hardened pupa-case. (The last phrase, I will admit, is not quite scientifically correct, but I do not wish to complicate the subject by introducing a multiplicity of technical terms unknown to my readers.) in No. 6 you can see the adult grub in the very act of thus turning round, head to tail, within his outer skin, so that he may be able to emerge as a full-grown fly, head upward. A tiger is nothing to it, though a tiger moves within his own integuments more freely than most of us. You will note that during the feeding stage the grub's mouth and under side were pressed against the stem; when he has performed this curious somersault on his own axis, so to speak, the head is uppermost, but the mouth and under side of the body are turned outward towards the sheath, not inward towards the stem and hollow centre of the barley-plant. He wants now to bite his way out, not to suck at the stalk for its nutritive juices.

I need hardly add that it takes some watching to detect such invisible movements inside a hard dark case ; and only by the closest and most unweary- 
ing attention was Mr. Enock enabled to discover the true use and meaning of the so-called "anchorprocess." It is really not an anchor, but a sort of hooked foot or lever, hy whose aid the apparently dormant grub turns himself bodily over within his ow hardened skin, now become too large for his shr ien body.

Discoveries like these are hard to make; yet they bring little return in money or glory. But it is only by such patient and careful investigation that a way can be discovered to get rid of pests which cost civilisation many hundreds of thousands, nay, many millions, anmually.

The grub in the turning stage is thus by no means what he looks-a dormant creature; on the contrary, he is a gymmast of no small skill and activity. The muscular contortions by which he seeks to free himself of discomfort when disturbed by man show that he possesses great power of contraction, and that he can exercise a considerable force of leverage.

After the grub has stucceded in putting itself in position for assmung the winged stage, and emerging from its home head upward, it hegins next to grow into a true pupa, or chrysalis. It is in the pupa, of course, that all winged insects acpuire their wings and become definitely male or female, and this stage is, therefore, one of the most important. As soon as the grub begins to reach it, he swells once more and grows quite tight inside his larval skin, which is stretched so much that it seems to be bursting. At last, as he wriggles and 
twists within it, the skin does burst, first over the mouth and head, and then over the central joints of the body. Again the insect twists and wriggles inside this half-broken skin, and again he pushes it backward toward his tail, till at last he has sloughe: it all off entirely, and it remains a shrivelled relic - an empty case-in the spot where he has hitherto lived and breathed and had his being. He is now a true pupa, white at first, but gradually growing a delicate pink, and then rosy.

Just at first, however, the pupa looks almost as formless as the grub it replaces, revealing no limbs or distinct segments. But little by little, feet and legs and eyes and wings begin to be visible through the semi-transparent shell of the chrysalis. $\mathrm{He}$ is changing slowly into a winged insect, and you can watch the change through the delicate horny coverings.

Stranger still, the Hessian fly at this stage is not torpid and quiescent like most ordinary insects. The papa, as in many of this family, is locomotive. It hats legs and feet, and it can wriggle its way up, as you see in No. 7, where the lower object is the empty larval skin, now deserted by its inmate, while the upper one is the pupa, emerging from the sheath, and making its first experiences of the wide, wide world outside its native leaf-bound hollow. It is ready now to come forth from the pupa stage, and to fly forth in the open air in search of a mate with whom to carry on the serious business of replenishing the fields with new generations of similar 'arvae. 
The succeeding illustrations show you in detail the various stages in the process of emergence. No. 8 gives you the beginning of emancipation. The pupa has here bitten its way through the leafsheath with its hard, horny jaws, and is protruding visibly. Just at first, only the head itself gets free; then the insect rests a while after its ardous labour, and begins wriggling and writhing again, this time working out its body or thorax. After another short interval for recuperation after such a territic effort, it manages to pull its legs through the hole, and to support itself upon them by resting them like at bracket against the stem of the barley. This is the point just reached in the illustration No. 8. There the pupa stops

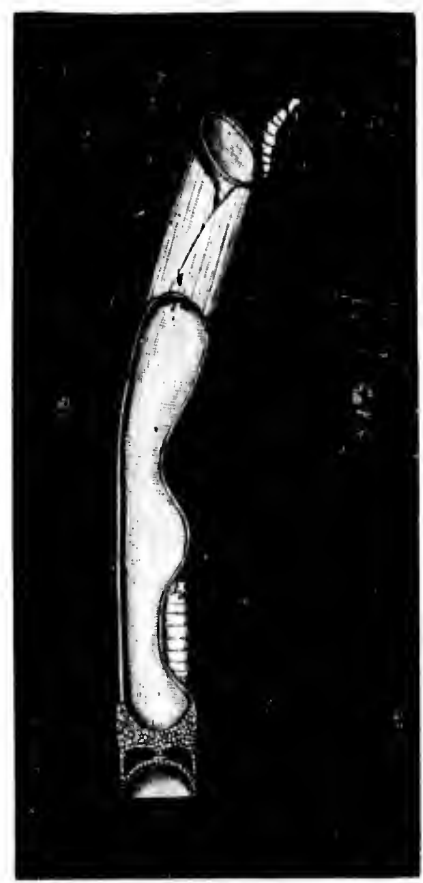

NO. 7.-THE CI.IMBING PUPA; BELOW, THE RMPIY CASE. short, having got himself into a convenient position for dispensing with his coverlet; for the sheath of the barley grasps the pupa-skin tight as in a vice, and he can wriggle his winged body free within it, without paying 
any further attention to the disused mummy-case which once confined it.

In No. 9, the pupa being thus safely anchored, the fly is emerging. It is a slow and delicate process, for with so many legs and wings and

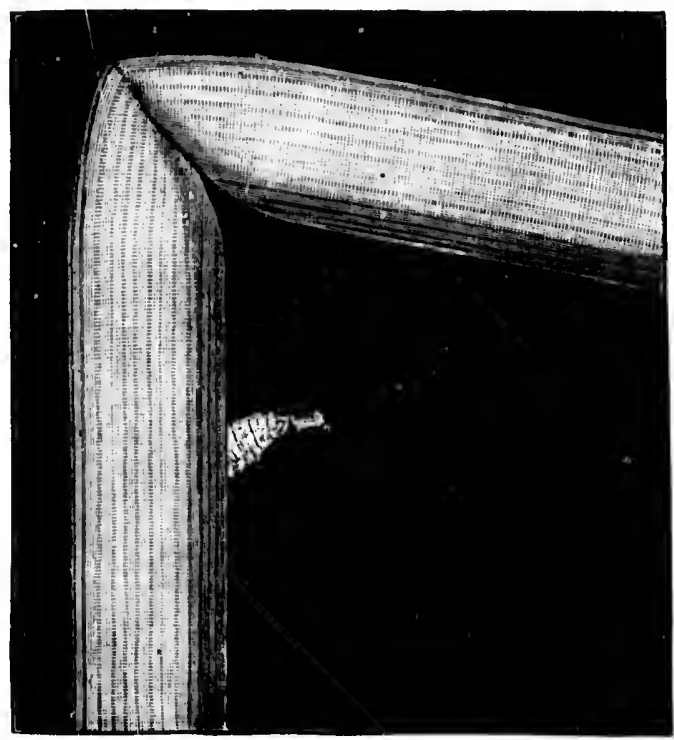

NO. 8. -THE PUPA COMES OUT.

antennae and appendages to get free from the mumny-case, onc cannot hurry: haste might be fatal. At this first stage of emergence, as you will observe, all the important parts are still cramped at their ends within the pupa-shell; but you can see how the legis and antennie are striving to dis- 


\section{A Foreign Invasion of England 301}

engage themselves. The pupa covering is propped as before by the empty legs-shells so ats to form a bracket.

In No. Io-hurrah! with a supreme effort, our fly has got her antenna free! She can move them

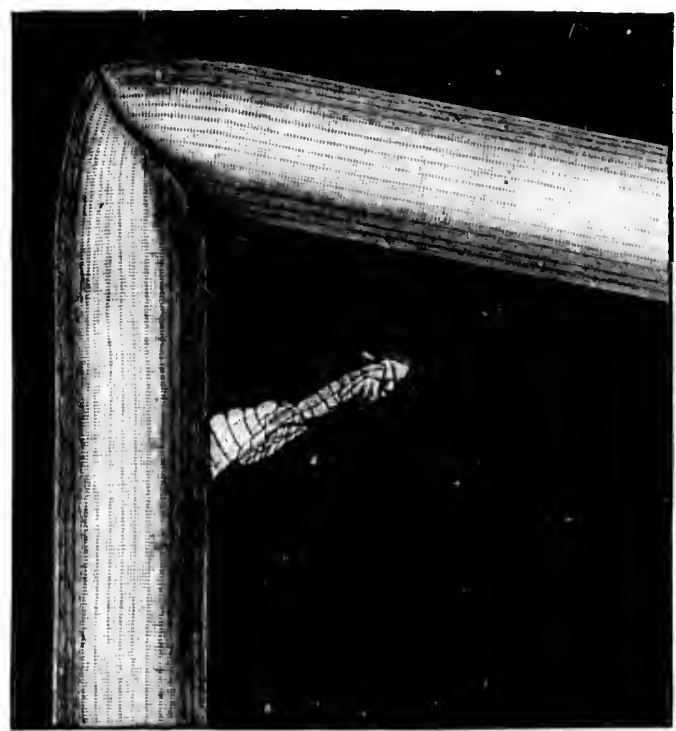

NO, 9.-AND THE FLY COMES OUT OF IT.

to and fro now, in all thei: jointed and tufted glory. That enables her to was her head in either direction without difficulty, and encourages her to go on to fresh exertions for the rest of the deliverance. But her feet are still fast in that hampering mummycase; she must try her hardest now to free them each carefully. 
First, however, let her get the tips of her wings free to help them. One good jerk and out comes the first wing. Now she bends backward and forward and seems straining every nerve. Halloa, that did it the other wing is free! Not as yet,

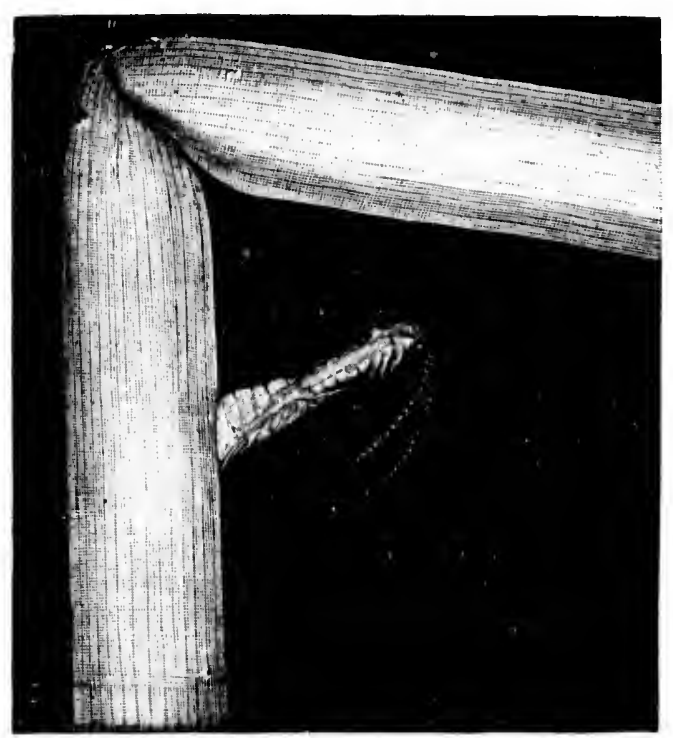

NO, IO.-ANIENNE: FREE !

however, plimmed out and flattened as it will be a little later; both wings at present look somewhat thick and lumpy and stick-like. Such as they are you see them in No. I I, rather clumsy specimens, while our lady goes on with redoubled energy, now concentrating her efforts on her front pair of legs 


\section{A Foreign Invasion of ENgland 303}

- for when you bave six to think of, one pair at a time is about as much as you can easily manage.

In No. I I, the first pair, you will note, is all but free. She wriggles ont one of them, and then its fellow. Oh, how she tugs and pulls at them:

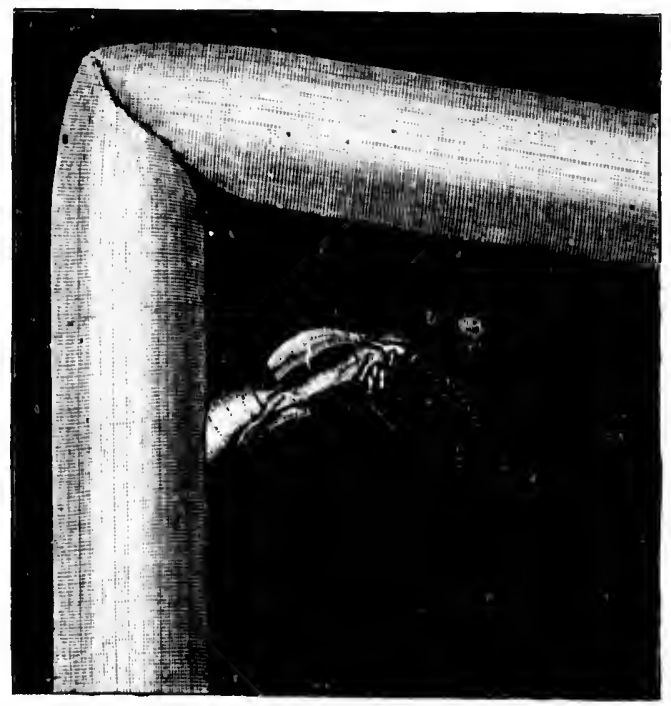

NO, II.-WINGS FREE!

Meanwhile, the tufts of hair on the antenna, which at first were bunchy and little developed, have begun to expand; she looks, hy this time, distinctly more like a respectable insect. Well done, once more; two pairs of legs now free. No. I 2 shows them. But, take care; we are getting now rather far out of the mummy-case. Be sure you 


\section{4

don't overbalance, and tumble bodily out, tearing your hind pair of legs off, with the force of your fall. Those thin shanks are brittle, and you find little support now from the empty skin and the hollow bracket.

Nature, however, is wiser than her critics. Just

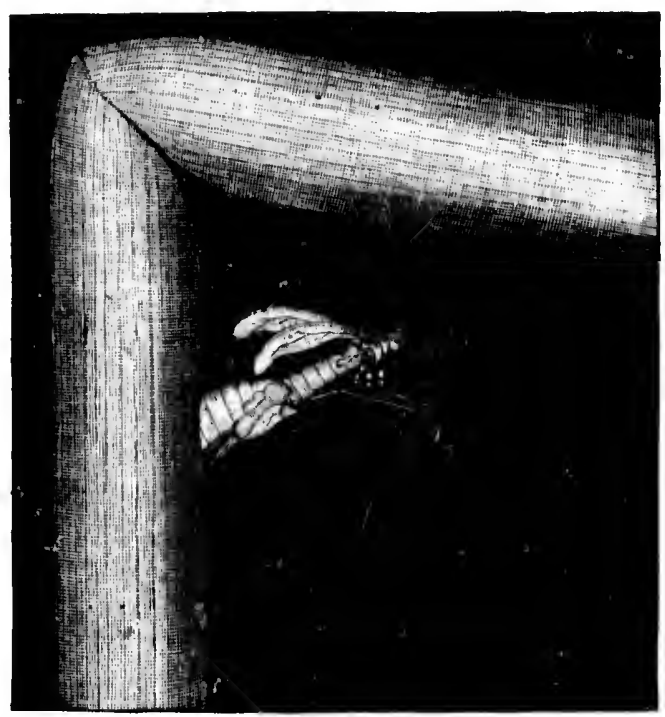

NO. I2,-NOW FOR THE LEGS !

when it looks as if next moment the fly must lose her balance and topple over, she twists suddenly round, with a clexterous lunge, catches the bent stem with two of her free legs, and anchors herself securely. No. I 3 shows how this is done. Below is the now almost empty pupa-shell, still enclosing 
A Foreign Invision of Exgland 305

the last two legs, on freeing which our astute little enemy is busily occupied. But with the two legs on her upper side (as she stands in the illustration) she has caught at the barley-stem, one foot being firmly planted below the hend, and one above it. This gives her a fine purchase to depend upon

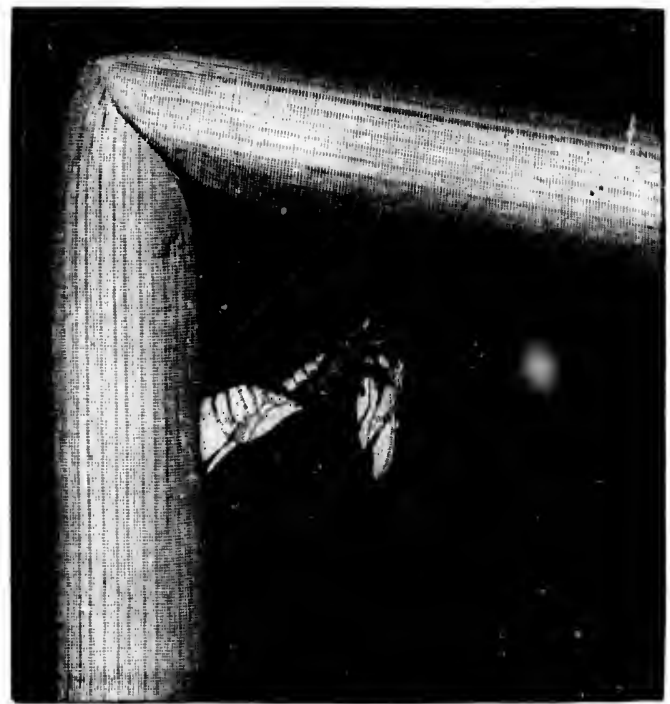

NO. I3.-THE LAST PULL; THE USE OF LEVERAGE.

in her last wild blow for freedom. A long pull, and a strong pull, and she has got-what the modern woman so ardently craves-complete emancipation! The third pair of legs are out at last; she has all the world before her to wander over and lay eggs in. 
In No. I t you see her, then, free, but resting. She has now shaken herself out, and left her empty mummy-catse imprisoned at her side in the sheath which holds it. Its fate no longer interests her. Then slue crawls a little way along the surface of the barley stem, and presently, clasping it with

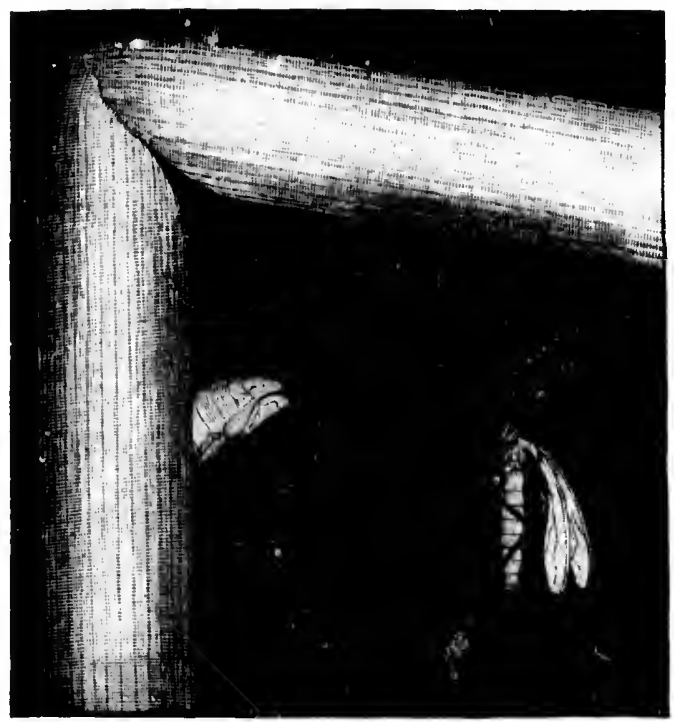

No. I4.-HANGING HERSEL UP TO DRY.

her four front legs, she hangs herself up, tail downward, to dry in the sunshine. No. $r+$ graphically represents this curious position. Almost all flying insects, when they emerge from the chrysalis stage, do something analogous. Their wings are still club-like, their antennae undeveloped or not 
fully expanded, their jointed lesss weak and grogesy. But after a time, as they breatle or intlate themselves with air, all these parts srow fuller, lighter, and harder. The Hessian fly in this predicament waves her wings to and fro several times across her back; and in about a yuater of an hour they have plimmed out fully, so that she can soar away on her marriage-flight to meet her prospective aerial husband. As for the tiny silvery shroud or deserted pupalcatse, it is left protrading from the stem of the batley.

This that I hate given you is the history of a sucesssful and fortunate tly ; hut not erery individual of the species is yuite so lucky. As in the catse of the mosquito, nature at times makes not a few failures. Sometimes the flies hate insuperable difficulty in frecins themselves from their articulated coverings; sometimes they heak or spoil their legs or wings, and become helpless eripples. Yet so strongs is the impulse of every species to fill the workd with its like that sometines, salys Mr. Enock, even these poor mained incects will manage to crawl to a proper food-plant, and will lay their essss on it brarely like their more fortunate sisters. He noted one erippled female which in spite of its feebleness was eighty times over a happy mother. This is usually the ease with such small insect pests; their life consists, incleed, of two things only, eating their way to the winged stage, and then laying ats many eggs as possible, to do like clamage in the next generation.

Three or four hours after emerging, when they 
have had time to accustom themselves to the outer air, the male flies soar abroad on gauzy wings to seek their mates; the ladies, on the contrary, are coy, not to say somewhat sluggrish, and oftenest wait at home on the under side of a leaf till their lorils come to woo them. The well-bred Hessian fly does not gad about to seek a husband. But that is only while she is a maiden; as soon as it comes to laying eggs, she wakes up at once, and takes to business with the utmost energy. She flies off around the fiekts and looks out a fresh young barley-plant, suitable for a nursery. On its leaves she alights, with her head towards the tip of the blacke, and begins depositing her precious burden. When once she has started, she sticks to it for life, using herself up (like our old friend the aphis) in the chuties of maternity, and laying as many egges as she possesses material for. Her conduct, in short, would be exemplary, if she wasted her life on thistles or nettles, and didn't choose to display her maternal affection on the British farmer's barley. So she goes on till she has worn herself out, and often till she has broken three or four of her legs in the pursuit of duty. Then, when she grows quite exhausted, and feels her latter end drawing nigh, she hides herself in the ground - buries herself alive, in fact; and there awaits cleath with patient resignation.

The average lifetime of the Hessian fly in the alult wingel stage seems to be about five days for the females, and probably a good deal less for the males. The bachelors in search of a wife fly some- 
times for long distances across country ; but their prospective partners are almost always shyer and more maidenly; they hide under the leaves and travel but short distances, consiclering, it more ladylike to stop at home and wait for suitors than to go out and seek them. 'They are not new women. Indeed, so great is their modesty that they often hide in holes in the sromel to escape observation; and they usually alight on the earth, as their colour is blackish, and they are there less exposed to the attacks of bircls and other enemies than on the green foliage. It is a noticeable fact in nature that many species of animals seem thus to know instinctively the colours with which their own hues will best larmonise, and to poise by preference on such colours; niany dappled or speckled insects, for example, resting with folked wings on the dappled and speckled flower-bunches of the carrot tribe, while green insects affect rather green leares, and brown or black insects cone to anchor on the soil, which best protects them. This is not quite the same thing as what is called protective colouring, such as occurs in desert animals, most of which are spotted like the sand, or in the fishes and crabs which frequent the sargasso-weed in the Sargasso Sea, all of which are of the same pale lemon-yellow tint as the seaweed they lurk among; for this case of the Hessian tly includes a deliberate choice of ingrained habit. The insect has many objects of many different colours spread about in its neighbourhood, but it habitually selects as its resting-place those particular objects which 
most closely approach its own peculiar groundtint.

It is a curious fact, however, that in spite of all the apparent pains hestowed npon securing the perpetuation of such destructive creatures as the Hessian fly, the pest itself lats its own enemies, as fatal to its life ats it is to the harley. Ichnemmon flies and other parasites prey hy millons on the Hessian fly in its smub condition ; and many sood authorities believe that the safest waty of checking the depredations of the harley-plange is by encourasing the multiplication of its matural enemies. No. I 5 show's us one of these industrious little scourges actually at work. She alights on a stem of barley infested by sarubs of the Hessian fly, and walks slowly along it, tappins gently as she goes, much as a woodpecker taps with his hill on a tree-trunk to discover the spot where a worm lies buried. After carefully examining the surface, she finds at last a place where something, either in the somnd or the feelings of the stem, reveals to her the presence of a Hessian fly grub within the leaf-sheath. Having accurately diagnosed the spot (like a doctor with a stethoscope), she brings her ovipositor (in plain English, her esss-layer) just above the place where the sabuh is lying snus in its green bed, and pierees the hard leaf-blade with her sharp little lancet. Then she lays her egg in the body of the larva. This egs gives rise in time to a parasitic grub, inside the first one; and the parasite eats out his host's body, and emerges in due time as a full-grown fly, ready to carry on the 
same cycle in future. More than nine-tenths of the Hessian fly grubs hatched out in America are thus destroyed hy parasites hefore they reach maturity; and it seems likely that the surest way of fighting insect plagues like the Hessian fly is by encouraging the increase of such natu. ral destroyers.

At first sight, to be sure, it may seem improbable that man could do anything to "encourage" the reproduction of such very small creatures; but that is not really so. All that is necessary is to keep the straw in which the parasitic srubs abound, and so allow the two hostile kinds to fight it out among themselves for the farmer's benefit.

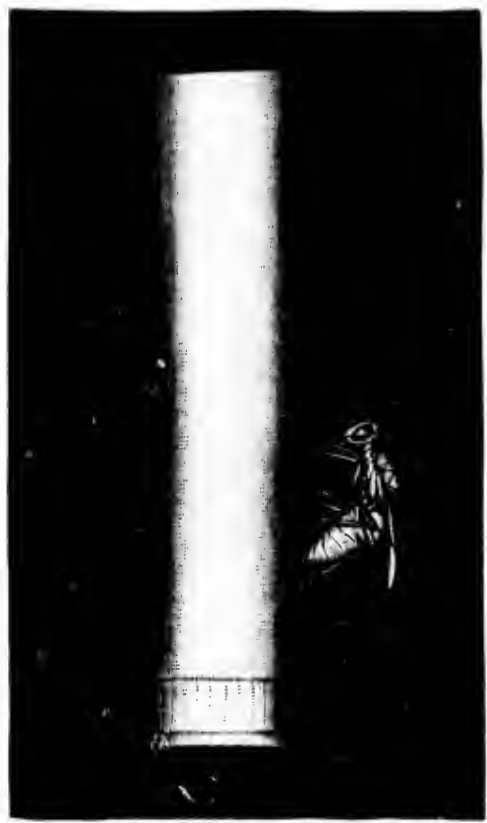

SO. I5-WHY FNEMY TAYING HER EGGS IN THE I.MUS. Mr. Enock mentions an instructive case of this sort from America, where the Californian orange-growers were almost being ruined by the depredations of the scale-insect, a queer little beast which you 
may often find on the rind of certain import oranges. But an enemy to the scale-insect w discovered in Australia - an enemy to the scal insect, and therefore an ally of the harassed orang grower. It was a particular kind of ladybir which devours in its larval stage whole tribes the scale-insects. That wonderful entomologi: Professor Riley, whose services were worth man millions of pounds to the American farmers, $g$ wind betimes of this new destroyer, and import a few specimens, actually sending a skilled age to Australia to collect them. The precious litt creatures were housed at once in a muslin ter covering a scale-infested orange tree; and ther rising to a sense of the duty imposed upon ther they laid their eggs on the leaves with commen able promptitude. The larva soon hatched ot and began feeling upon the scale-insects; and an incredibly short time there were beetles enoug on that single tree to distribute by boxfuls amon the distressed agriculturists. The result was th before very long the scale-insect became a ra specimen in California. But that was in $t$ United States; English folk are too "practica to take any notice of those theoretical men science. They put their hands in their pock and let their crops get destroyed in the good "practical" way; then they shake their heads a observe with a smile that "there are great di culties" in the way of doing anything. 
